QL

633

N8C 65

1903

Fishes 
Aล $1 / 2$
12

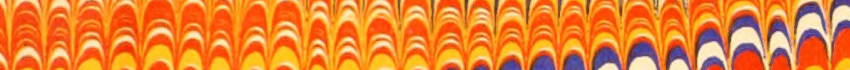

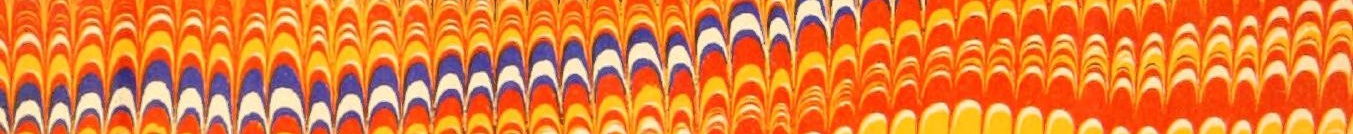
ล้ล

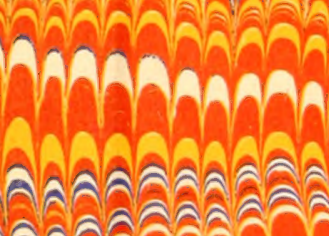
ลิลคิ⺈

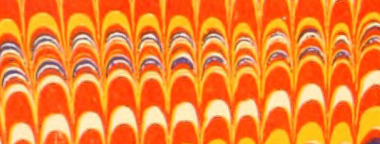

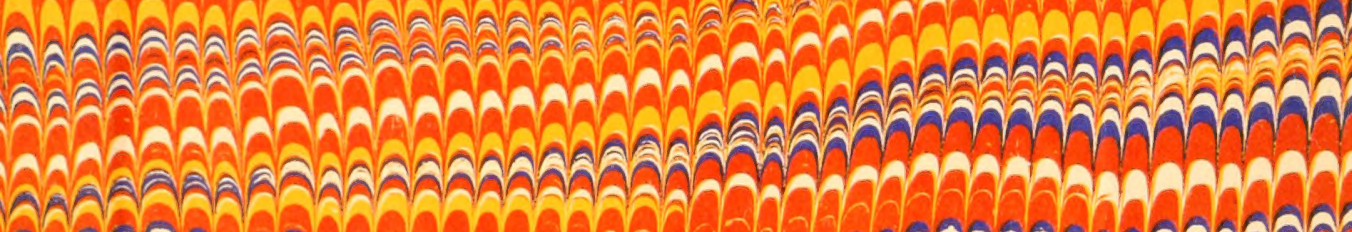
-1.

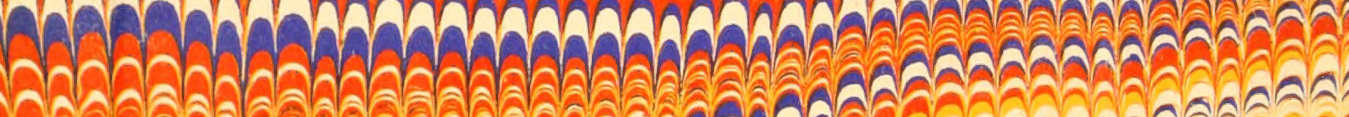

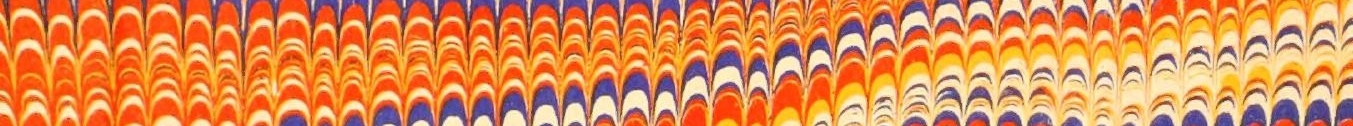

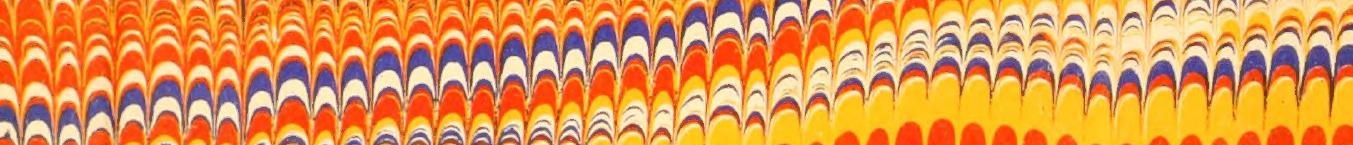
ฟลล

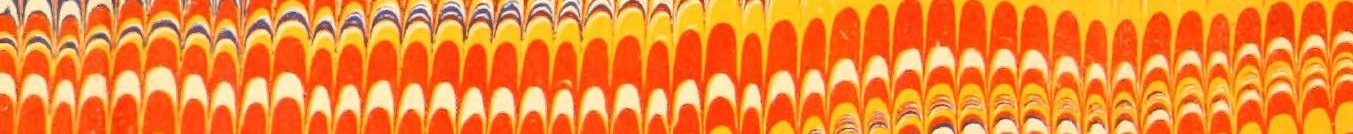

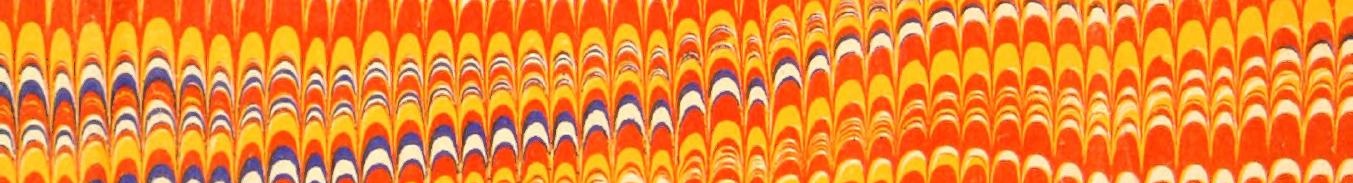
(1)

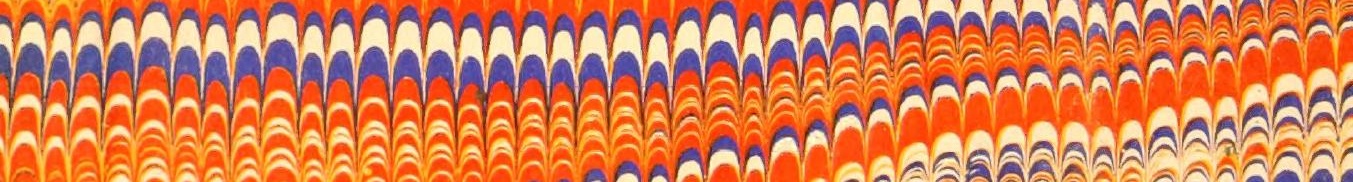
1 - 1 An

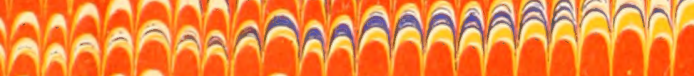

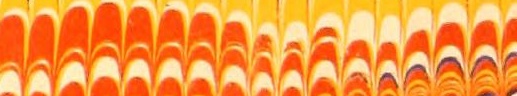
Nonal

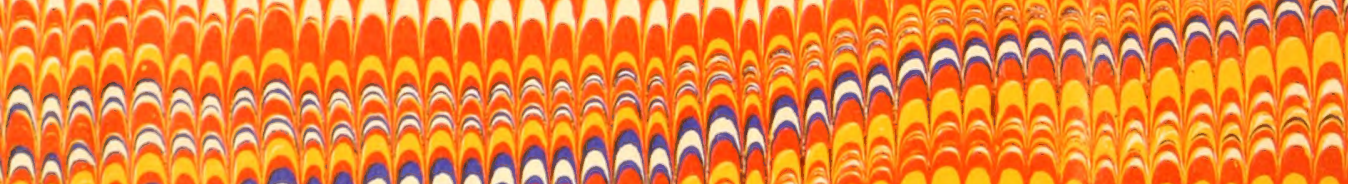
- a

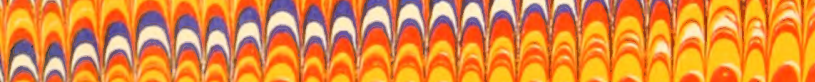

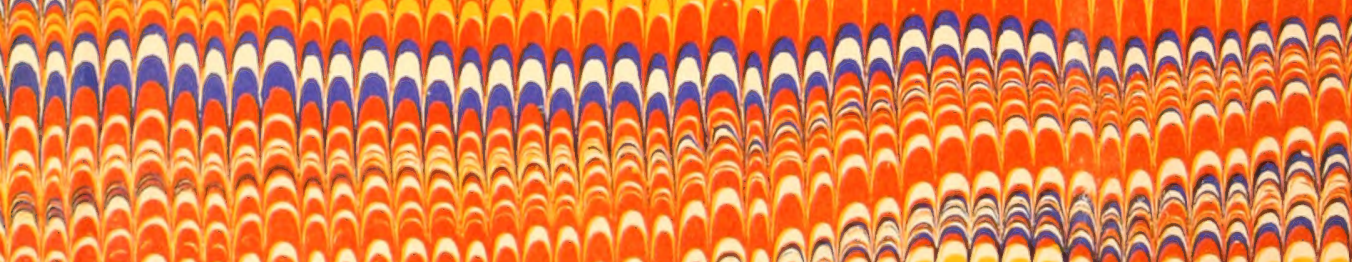

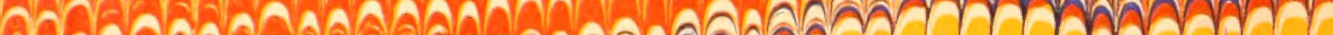




\section{a a a a}

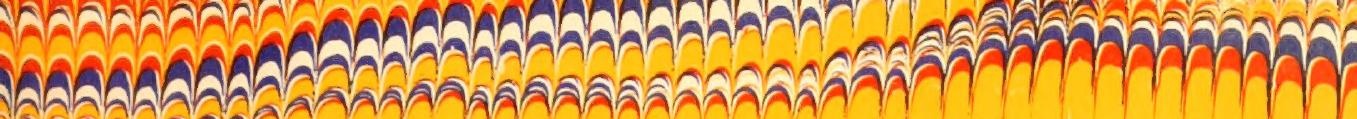
Wh

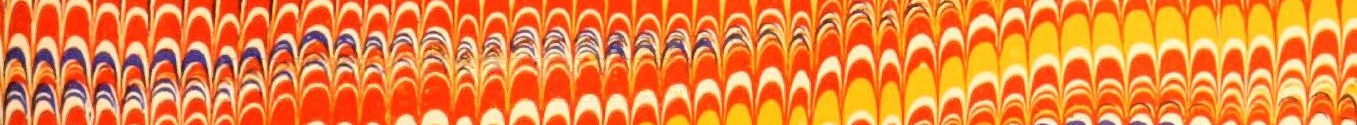
等

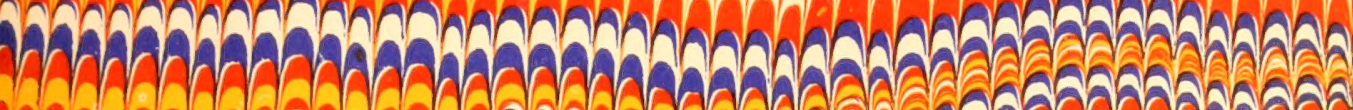
C

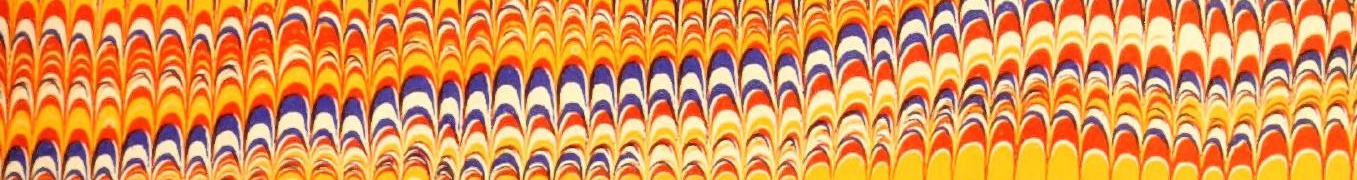
Bi

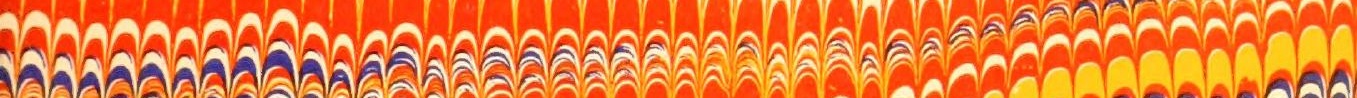

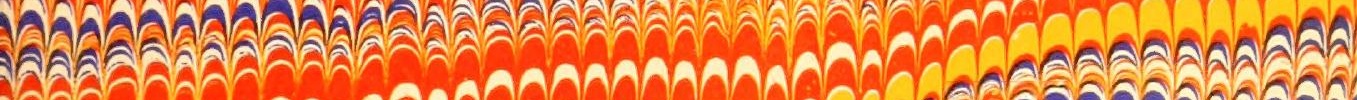

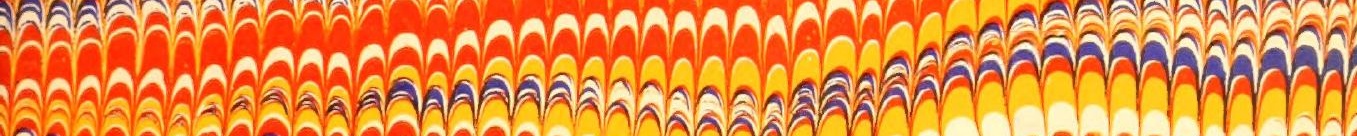
606

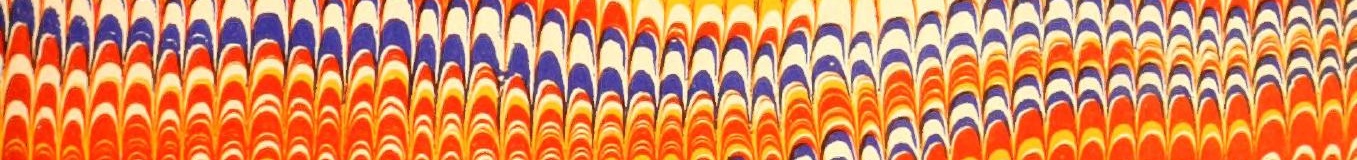
A

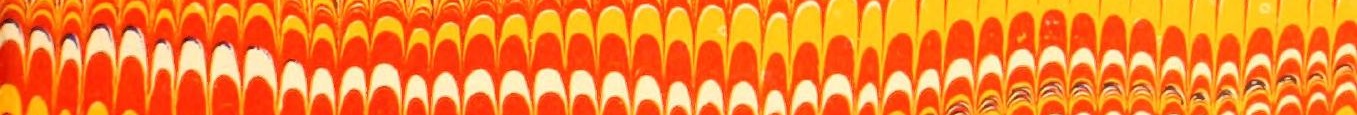
คAา A A A H

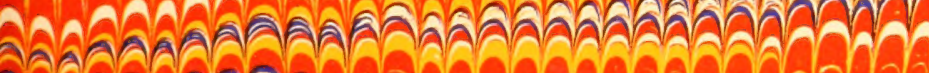

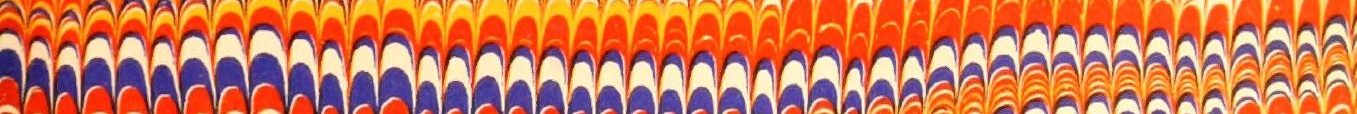

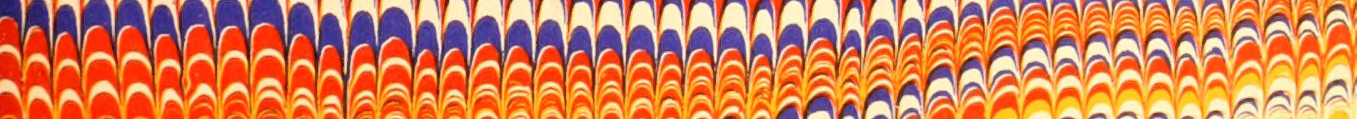

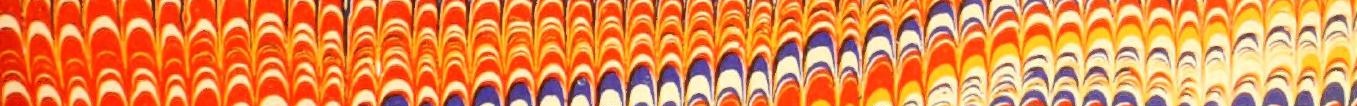

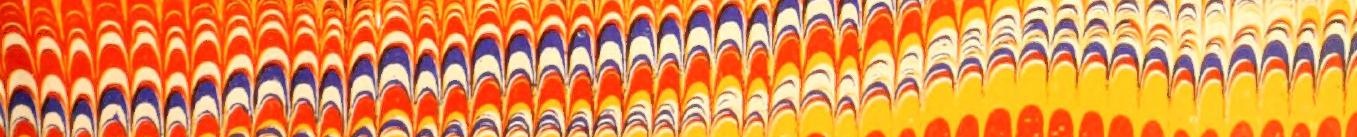

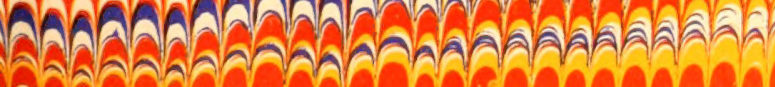







i Aarene 1884-1901

(3die Hoved-Supplement til "Norges Fiske")

\section{II}

Fortsat fra Forh. Vid.-Selsk. Christiania 1902, No. 1

(Obristiania Videnskabs-Selskabs Forhandlinger for 1903. No. 9.)

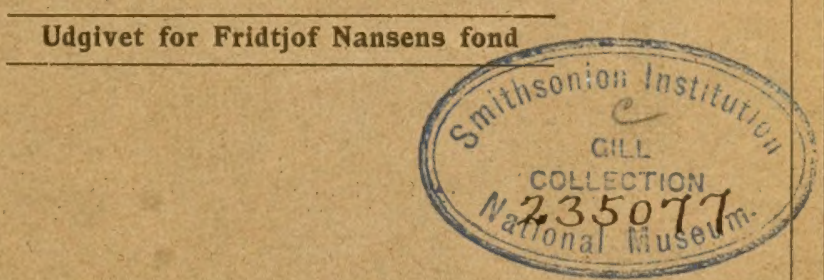

\section{Christiania}

I Commission hos Jacob Dybwad

A. W. Brøggers Bogtrykkeri 



\section{Meddelelser an Noryes Fiske}

\section{i Aarene 1884-1901}

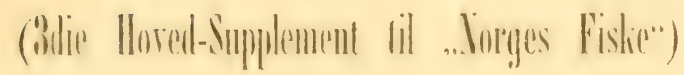

\section{II}

Fortsat fra Forh. Vid.-Selsk. Christiania 1909, No. 1

Af

R. Collett

(Christiania Videnskabs-Solskabs Forhandlinger for 1903. No. 9.)

Udgivet for Fridtjof Nansens fond

\section{Christiania}

I. Commission hos Jacob Dybwad

A. W. Broggers Bogtrykkeri 



\section{Meuddelelser onl Norges Fiske i Aarene 1884-1901.}

3die Hoved-Supplement til "Norges Fislie".

II.

Fortsat fra Forh. Vid.-Selsk. Christiania 1902, No. 1.

Af

R. Collett.

(Fremlagt i Fællesmodet 20de Marts 1903.)

\section{Fam. Lycodidae.}

Lycodes vahlii, Reinh. 1830-31.

Lycodes vahtii, gracilis, M. Sars 1866.

4 Arter Lycodes ere hidtil fundne indenfor den norske Faunas Omraade, saaledes som dette efter de nyeste Under-

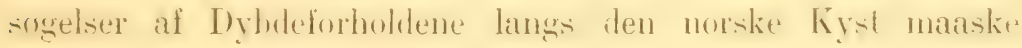
rettest kan begrændses ${ }^{1}$.

2 af disse Arter tilhore udelukkende det arctiske Gebet,

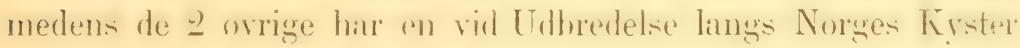
lige ned til Christianiafjorden.

1. Grændselinien for Norges 'Territorium tænkes trukken fra Hvaler langs Midten af Skagerak (indbefattende den dybe ${ }_{n}$ Norske Rende* ${ }^{*}$, og langs Landets Vestkyst, omfattende "den continentale Platform" med de moderate Dyb af indtil 400 Meter, der udad ere begræendsede af Eggene og de ovrige mere eller mindre bratte Fald mod Dybet. Denne continentale Platform naar sin mindste Bredde udenfor Sondmor, hvor den standser i „Storeggen“, samt udenfor Vesteraalen og T'romsø-Kysten („Havbroen"). Udenfor Finmarken, hvor de store Dyb ligge fjernere fra Kysten, kunde Grændselinien trakkes i omkring 100 Kilometers Afstand fra Land. 
Af de sidste er L. sarsii udbredt spredt, og (som det synes) i ringe Anlit latus- Kistlinien fra Polarcirlielen af og ned til

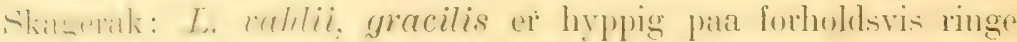

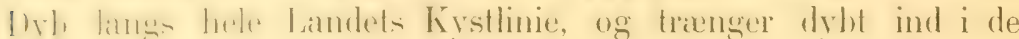

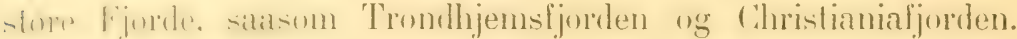

Af de ovrige er $L$. rossii forst i de sidste Aar paavist som Beboer af den finmarkske Kystarea; L. esmarkii tilhorer -immme ()mrate. men er her tilsvoladende stationer og forlublisvis litrig. on endog Gjenstand for Fangst af Fiskerbefolkningen, uden dog at være af oconomisk Betydning ${ }^{1}$.

\section{L. vahlii, gracilis, M. Sars.}

\section{Diagnose.}

Legemsbygn ing. Legemet af typisk Lycode-Bygning, temmelig langstrakt (zoarciformt); Hoiden, maalt over Anus, indeholdes 9,5 til 10,5 Gange i Totall. Hovedet indeholdes hos Hannerne omkr. 4,5, hos Hunnerne omkr. 5 Gange i 'Totall. Halen (regnet fra Anus) længere, end Hoved og Krop tilsammen; Legemet indtil Anus indeholdes indtil 2,5 Gange i Total. lengden.

Farven varierer med Alderen. Smaa Unger have 8-10 brede, morke, tretstaaende Tverbaand nedad Legemet. Hos de noget aldre forsvinde i Regelen disse fuldstiendigt, eller blot svage Spor bibeholdes, tildels $\mathrm{i}$ Form af uregelmæssige eller ringformige Pletter nedad Legemet; Bundfarven er her ofte ensfarvet graabrun, Undersiden noget lysere.

De fleste yngre Exemplarer have en Rekke smaa, graabrune Pletter henad Legemets Midtlinie; ligeledes findes hos de fleste i Dorsalens Begyndelse med kort Mellemrum 2 brunsorte Pletter.

Skjælbeklædningen er i Frembrud hos Individer med en 'Totall. af omtr. $60 \mathrm{~mm}$. Hos de udvoxede dækker Skjællene hele Legemet indtil Hovedet, samt Grunden af Dorsal og Anal.

2. L. frigidus, Coll. 1878, og L. muraena, Coll. 1878 ere begge fundne saalingt mod $\bigcup_{\text {st }}$ i Nordharets iskolde Area udenfor Nordland og Lo. foten, som denne strækker sig ind mod de norske Kyster (eller i Grandsen mod de bratte Egge), men de ere endnu ikke paaviste paa de indenfor liggende grundere Banker eller "den continentale Platform", hvor Dybden er ringere, end 400 Meter, og Temperaturen i Dybet er over 0. I et Par tidligere Afhandlinger (Forh. i Vid.-Selsk. Chria. 1879, No. 1, p. 65, og Arch. f. Math. og Naturv, B. 19, No. 8, p.4, Chria. 1897) har jeg henfort begge disse Arter, der optoges under den Norske Nordhars-Expedition Sommeren 1878 i 100-230 Kilometers Afstand fra Lind, som luenhorende under den norske Faunas Omraade; men med den Begrandsning af dette, som ovenfor er antydet, kunne de endnu neppe med fuld Ret opfores herunder. 

Vomer.

Tænder normale; tilstede i Kjaverne paa Palatinbenene og paa

I. B. 6. Sidelinien ventral, (ucomplet). P. 17 eller 18, sjelden 19.

Storrelse. Er forplantningsdygtig med en 'lotall. af $120-150 \mathrm{~mm}$. Den storste hidtil iagttagne Længde hos scandin. Exemplarer er $270 \mathrm{~mm}$.

$H a b$. Kattegat, Skagerak, Norge, Island, Beeren Eiland.

Historie. Den eneste Art af denne Slægt, som forekommer i storre Antal langs hele den norske Kyst, er L. vahlii, eller denne Arts scandinaviske Form L. gracilis. Denne bebor her det forholdsvis grundere Vand, og trænger dybt ind i Fjordbundene.

Under en Række Undersogelser over de arctiske Lycoder

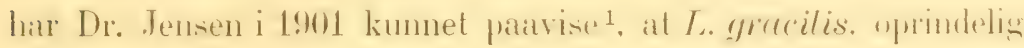
kjendt og beskrevet fra Christianiafjorden, er at opfatte som rm sydustlig. reliet Form af den typiske I. cahlie, som neppe mogensinde i de scandinaviske Farvande opmaar den typiske drts fulde Storrelse, og i Overensstemmelse hermed udviser et ringere Antal straaler og Ivirvler, end de gronlandske Exemplarer af L. vahlii.

Af den sydlige Form 'er der forst i de sidst forløbne Aar hleven hilveluhagt et sail stort Materiale, at dens Udviklingsstadier fra den spæde Unge til det kjonsmodne Individ har kunnet forfolges.

L. gracilis blev første Gang paavist i Christianiafjorden

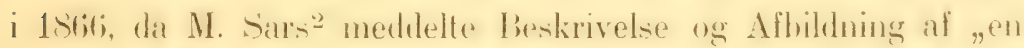
ny norsk Fisk. Lycorles aracilis," optaget i 186ir) fra 50-(i) Favnes Dyh 190 110 Detery i Drobaksmul. Fxemplaret var en

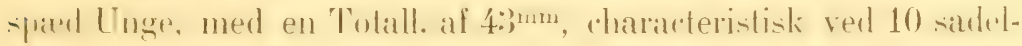

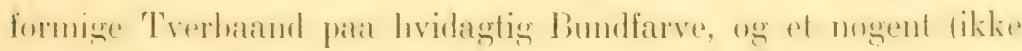
skjælbeklædı) Legeme. Brystfinnerne havde 17 Straaler.

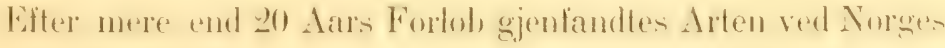
Kyster. I Juli 1888 optoges af Conserv. Storm i Trondhjemsfjorden fra en flybde af 70 Favne (12s Meter) 4 unge lixem.

1 Vidensk. Medd. fra Naturh. Foren. Kbhwn. 1901, p. 202.

2 Forh. Vid.Selsk. Chria. 1866, p. 40 (Chria. 1867). 
plarer af en Lygcotes, hris Totall. var $9 \overline{7}-13 \overline{7}^{\mathrm{mn}}$, og hvis Bestemmelse forehblig forhlev usikker, da de yngre Stadier endnu manglede ${ }^{1}$. Sommeren 1894 fandtes atter i Trondhjemsfjorden ef yngre lixemplar at samme Art, hvis Totall. var blot $47 \mathrm{~mm}, o \mathrm{~g}$ smm $\mathrm{i}$ alle Henseender stemmede overens med Typ-Exemplaret af $I$. gracilis. Ligesom dette besad det skarpt markerede Tverlinand nedid Legemet, medens disse hos de ovennævite noget storre Individer (fra 1888) var mindre tydelige.

Hoved-Naterialef til den scandinaviske Form af denne Art blev dog forst hragt tilveie i 1897 og 1898. I Juli 1897 optog Dr. I'etersen²'et Snes Individer paa forskjellige Steder i Skagerak, (Crullumafjorden, og ved Hällö Blinkfyr 'udenfor Bohuslen), samt i Læss $\curvearrowleft$ Rende i Kattegat; og i Juli og August s. A. erholdt Dr. Hjort under de fra Drobaks Biologiske Station udgaaede I'nlersugelser samme Art paa forskjellige Steder i Christianiafjorden, isier pai Dybderne udenfor Aasgaardstrand, samt omkring Drobak (helt ind til Øerne udenfor Christiania).

Sommeren 1898 gjenfandtes L. gracilis under de af Dr. Hjort fortsatte ridenskahelige Undersogelser af Norges Sydkyst paa andre Steder i Christianiafjordens Munding, saasom i Laurvigsfjord og Langesundsfjorden.

Tilsammen dannede dette righoldige Materiale, som jeg havde Leilighed til nsiere at gjememgaa, en uafbrudt Række op til de fuldt kjonsmodne Individer, skjont det storste af disse blot harde (en Totall. af $17 \mathfrak{S}^{\mathrm{mm}}$.

I mu sierskilt Afhandling ${ }^{3}$ har jeg i 1899 fremlagt de Iagttagelser, smm indtil det nevnte Aar forelaa om denne Form, -om her molnandles som en fra de ovrige Lycoder specifik skilt Art (L. gracilis).

1 Forelobigt omtalt som L. pallidus i Aarsberetn. om Trondhjems Museums 'Tilvext for Aarene 1888-90 (Kgl. Norske Vid.-Selsk. Skr. 1888 -90, p. V og VI), Thjem. 1892.

- Chef for den Danske Biologiske Station.

${ }^{3}$ Contributions to the Knowledge of the Genus Lycorles, Reinh. II Ly. codes gracilis, M. Sars. (Skr. af Vidensk.-Selsk. Chria. 1899, I, Math.Naturv. Klasse, No, 6.) Med Pl. I-III. 


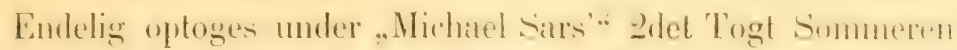
1901, under Dr. Honts Ledelse. 4 storre Exemplarer i Finmankens Fonde, de storste Exemplarer. der hidtil vides fumblne vend de europæiske Kyster af denne Art.

L. gracilis foreligger saaledes hidtil fra 3 vidt adskilte Districter af Landets Kystlinie, nemlig fra Finmarken. fra Trome. hjemsfjorden, og fra Christianiafjorden.

Da jeg paa det ovenfor anforte Sted (p. 13) har meddelt en udforlig Beskivelon af denne Formi Farvetegning og Legem.. hygning, skal jex her blot vedfore, foruden den Diagnose, som kan opstilles for Artens scandinaviske Form efter de foreliggende Exemplarer fra de norske Kyster, og som ovenfor er medilelt p. f. et Par Bemarkninger om de sidst erholdte storre Lixemplarer fra Finmarken.

Fra Finmarken. De nye Exemplarer fra Øst-Finmarken, hvis Totall. var fra $179^{\mathrm{mm}}$ til $270^{\mathrm{mm}}$, erholdtes paa 2 Localiteter. nemlig i Varangerfjorden, samt udenfor Baadsfjord.

Let storste af disse optoges udenfor Baadsford 1'tde Mai 1901 fra en Dybde af 160 Favne (omtr. 292 Meter). Dette Exemplar, som er det største, som hidtil er erholdt af denne Art fra de europæiske Kyster, havde folgende Maal:

Totall. $270^{\mathrm{mm}}$. Hovedets Længde $64^{\mathrm{mm}}$. Længde fra Snudespids til Anus $110^{\mathrm{mm}}$.

Exemplaret var en Han, med hvilende Testes. Hovedliengden indeholdtes hos dette Individ 4,21 Gange i Totallienghten. Legemets Længde til Anus 2,45 Gange i denne.

Exemplaret er iovrigt $\mathrm{i}$ alle Henseender overensstemmende med de: mindre Exemplarer af Artens scandinaviske Form. La. gemets Trerbaand mangle; 2 distincte [Pletter ere tilstede mor. Dorsalens forreste Strater; en Rakke hrunlige Pletter strakkin sign langs henad siderne af Bugen, og of Par lignende liunsHovedets Sider.

Pectoralerne havde 15 Straaler. 
De 3 noget yngre Expl. optoges i Varangerfjorden 6te Juni 1901. Tylukn var 100 Farne (omtr. 18:3 Meter). Deres Totallangde var $179^{\mathrm{mm}}, 192 \mathrm{~mm}$ og $220^{\mathrm{mm}}$.

If disse Expl. havde de 2 den for den scandinaviske Form

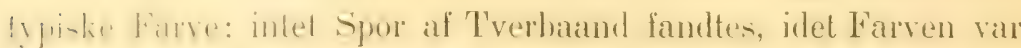

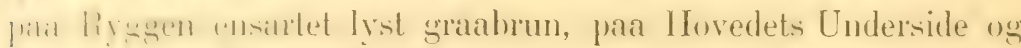
Bugen nates hivil. De z sorte Dorsalpletter vare tilstede. lige-

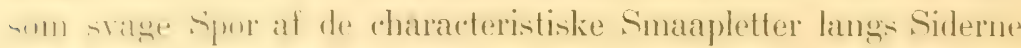
af Bugen. Pectoralernes Straaler vare 18.

Det mellemste Expl., hvis Totall. var $197 \mathrm{~mm}$, bærer endnu lins-liygsiden spor af de brune Trerband; disse ere s i Antal. men ibethele sragt antydede, og have en Bredde, der omtrent w lig sumdens. Doisalen mangler de sorte Pletter fortil. Dette lixpl. viser i Farvetegning og Habitus en tydeligere Overgang til den Iypiske $L$. ecthtii fra Gronland, end noget af de orrige scandinaviske Expl., som jeg hidtil har undersogt.

Tilholdssted. Ved Norges Kyster forekommer denne Art paia forholdsvis ringe Dyh, og den optages af Fiskerne temmelig hyprigh under de Fiskerier efter den saakahlte Dybands-Riege (I'mulalus borealis), som i de seneste Aar har foregaret i for-kjellige Fjorde og Havbugter ved Landets Sydkyst. Demne Fangel drives i Mundingen af Christianiafjorden i Regelen paa

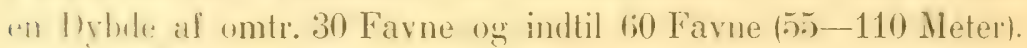
l'me de videnskabelige Expeditioner ere de erholdte paa de nuset storre Dyb, saledes red Finmarkskysten paa en Drbde af næsten 300 Meter.

Den Fode, som jeg har fundet indeholdt i en Del unge Rxmplaner har christianiafjorden og Trondhjemsforden, har be-

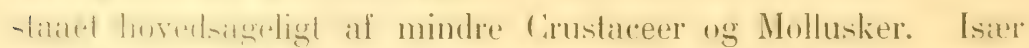

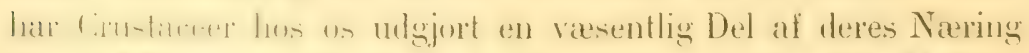

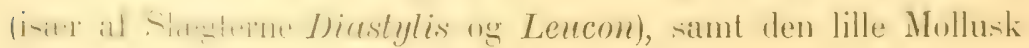
Kelliella.

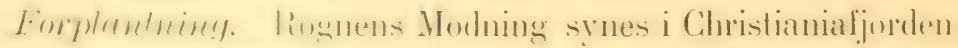

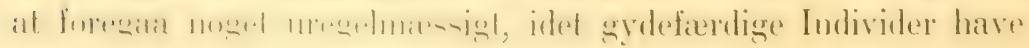


været fundne saavel om Sommeren, som om Hosten. De fleste gyde sandsynligvis i September og October.

Hos de fleste Hunner, der her ere fangede i Juli, vare Eggene endnu ikke fuldt udviklede, idet nogle al disse vare halvvoxne,

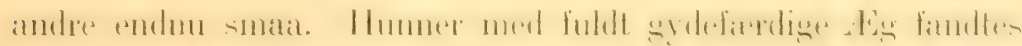

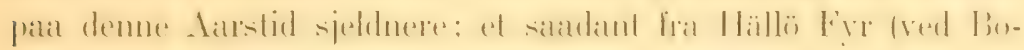
huslen), optaget 29de Juli 1897, og som havde en 'J'otall. af omtr. $150^{\mathrm{mm}}$, indeholdt 48 Rogn; hos andre (smaa) Individer

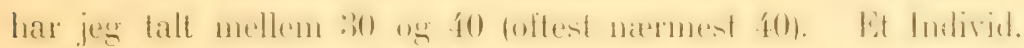

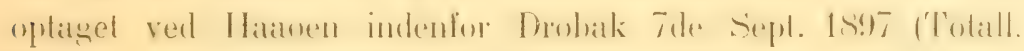
$137 \mathrm{~mm}$ ), var øiensynlig midt i Gydningen; Rognene, der vare colossale, havde en Diameter af $4^{\mathrm{mm}}$, og udfyldte næsten hele Bughulen. Deres Antal var her blot 27, idet flere maa antages allerede at have været gydte.

Humnerne begronde allerede at blive forplantningalyotige. naar de have naaet en 'Totall. af $120 \mathrm{~mm}$ og med en 'Totall. af $125-130^{\mathrm{mm}}$ ere saagodtsom alle Hunner om Sommeren drægtige.

Hanner med store Testes har jeg undersogt med en 'Totall. af $153^{\mathrm{mm}}$; med fuldt modne 'Testes med en Totall. af $160 \mathrm{~mm}$.

Udbredelse. 1. Fra Christianiafjorden foreligger, foruden

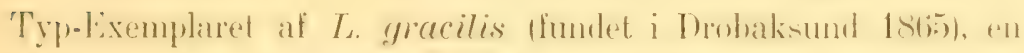
Ravke af Individer. optagne i Aarene 1897-1901 pata folgende Localiteter:

Fjorden udenfor Christiania (Lysakerfjorden).

Drobaksund, samt tilstodende Dele af Fjorden.

Fjorden udenfor Aasgaardstrand.

Onso-Kysten nedover mod Hvaler.

Bolærerne (udenfor 'T'onsberg).

Laurvigsfjord, og dens ydre Dele henimod Jomfruland

ב. I Trondhjemsfjorden er der fundet noghe fiat Exemplaren (ved Bynæsset) i 1888 og 1894 .

3. I Finmarken er den fundet Sommeren $1901 \mathrm{i}$ Varangerfjord, samt udenfor Baadsfjord. 
Sandsynligric vil den vise sig at forekomme langs den storste Wel den morke Kivt. naar hensigtsmæssige Fangstapparater

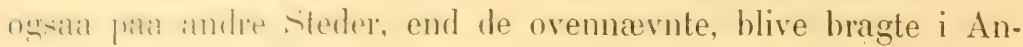
vendelse.

Lycodes rossii, Malmgr. 1864.

Ny for Faumaen. Et enkelt Expl. af denne Art er optaget under .. Hichael Sar'" 1ste Togt Sommeren 1900 i Porsanger. fjorden.

Exemplaret var en Unge, med en Totall. af 124mm, og opluges red Ostrebotten i Porsangerfjord fra en Dybde af 100 Meter Zúle Aug. 1900: Temperaturen i Dybet var $\div 1,15^{\circ} \mathrm{C}$.

Dette Expl. havde følgende Maal:

Totallængde . . . . : . . . $124^{\mathrm{mm}}$

Hovedets Længde. . . . . . $30^{\mathrm{mm}}$

Længde fra Snudespids til Anus . $57 \mathrm{~mm}$

Legemets Hoide . . . . . . . $13^{\mathrm{mm}}$

Hovedet indeholdtes hos dette Ind. 4,1 Gange i Totallængden, Legemets Længde til Anus 2,1 Gange i denne.

Legemets Tverbaand vare 9; "Nakkebaandet" var særdeles distinct.

Iøvrigt var Individet typisk farvet, som de fleste yngre Individer af denne Art. Bundfarven var lys, og Sadelbaandenes indre Dele hetydeligt lysere, end Randene, saa disse næsten fik Character af store Ringe. Det Sde og ade Baand fortsætter rig ud wrer Dorsalen og Analen, og danne saaledes 2 complette Baand over Halespidsen.

Anus ligger under Bagranden af 3die Sadelbaand.

Af dene Art, under hvilken som Synonymer indgaa L. cela l11s, J11-1.11 1901, og sandsynligvis L. lüthenii, Coll. 1880, fore-

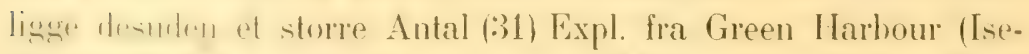

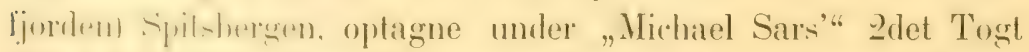
zode Juli 1901 stat sī) fra en Dybde af 140 Meter. Bundtemperaturen $+1,1^{\circ}$. Disse Exemplarer havde en Totall. af mellem $55^{\mathrm{mm}}$ og $215^{\mathrm{mm}}$. 
Endelig er af samme Art erholdt under "Michael Sars"،

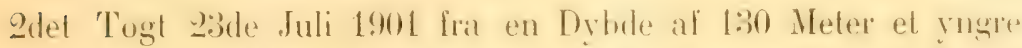
Expl. (Totall. 11(0mm) fra Banken syd lor Beeren Eiland; Bund. temperaturen var her $+0,5^{\circ}$.

Alle Exemplarer har jeg nøiere beskrevet i Archiv f. Math. og Naturv. B. 25, No. 2, p. 14 (Chria. 1903).

Bortseet fra alle tvivlsomme Synonymer er L. rossii (= L. celatus, Jens. 1901) hidtil fundel i den Del af Ishavel. som omfatter Gronland, Spitsbergen, Havet mellem Norges Nordkynt og Kara-Ilavet. Bundtemperaturen har varieret mellem iskoldt Vand (indtil $\div 1,6^{\circ}$ ), og tempereret (indtil $+1,1^{\circ}$ )

\section{Lycodes esmarkii, Coll. 1874.}

Cillnedelse. Til forskjellige Thider har jeg givet Meddelelse om den store og markelige Lycode, som forekommer tilsyneladende stationart og jevnligt fanges af Fiskerbefolkningen udenfor Fimmarkens Kyster, og som jeg i 1874 har heskrevet under Benærnelsen Lycodes esmarkii ${ }^{1}$.

Det Materiale, som hidtil foreligger af denne Art fra de nor-ke Kyster, har udelukkende bestuaet af de fuldt molvoxede og udfarvede Individer. Af de yngre Stadier er endnu intel med sikkerhed erholdt inden det Kyst-Omrade, livortil den norske Fauna rettelig bur hegrandses. Det yngste hidtil undersogte Individ har havt en Totall. af 4(6.5), og dette har i Farvestegning og Legemshygning varet fuldstandigt orerensstemmende med de fuldt udvoxede.

De nedenfor anforte spredte Bemærkninger vedrore derfor udelukkende denne Art i dens fuldt udviklede Stand, under densis Optræden ved de finmarkske Fiskevær.

Som red en tidligere Leilighed nevot ${ }^{2}$, havde jeg indtil lsw:? kunnet undersoge ontrent 20 Individer af denne Art, alle lansecle $\mathrm{i}$ Lobet af de sidst forlobne 20 Aar vod finmarken. 2 al di-se stammede fra Oxfjord (Vest-Finmarken). Resten fra Varde

2 "Norges Fiske", p. 95 Chria. 1874.

2 Nyt Mag. f. Naturv. 29de B. p. 73, 1881 (Chria. 1855). 
og Varangerfjorden. Disse Indiv. havde en Totall. af 675$705^{\mathrm{mm}}$; flere af disse var Hunner med gydefærdig Rogn i (1)iricl.

Siden 1884 har jeg atter kunnet undersøge et betydeligt Inlal Individer marsten jo) fra de samme Localiteter. Det overveiende Antal af disse, hvoraf de storste havde en Totall. af

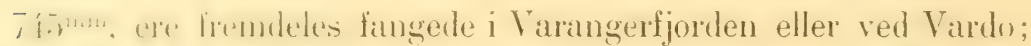
et Par St. ere ligeledes erholdte i Øxfjord. De sidstnæunte

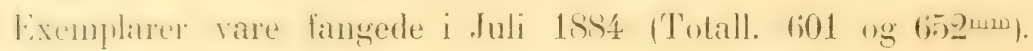
Længere mod Syd ere de hidtil ikke paaviste hos os.

L. esmarkii viser sig saaledes at bebo i ikke ringe Antal Whiterne udenfor Finmarkens Krster, hror Temperaturen i Whet ikke er under 0, fra Varangerfjorden af og ned til Grendserne af Tromsø Amt. Det overveiende storste Antal Individer we hiltil erholdte udenfor Vardo, samt i Varangerfjordens Munding; nogle enkelte ere fangede udenfor Oxfjord i Vest-Fimmarkin, men fra hele den mellemliggende Strækning vides hidtil intet Exemplar undersøgt.

Fungsten af denne Art foregaar i Finmarken hovedsiggeligt i Jen Tid, da "Loddefisket" indtræffer, eller i Mannederne April -.Juni, saaledes paa en Tid, da Dybvandslinerne fornemmelig henyttes ${ }^{1}$, og den erholdes herunder simmen med andre artiske Tyhandsfiske, som paa deme Tid viser sig under Land og ere Gijenstand for Fangst, saasom Hacrums berglax, Anarhichas latifrons, og lieinhardtius hippoglossoides. Hen Individer ere nasilit leilighedsvis fangede i Host-og Vintermanaderne. og jernlig wholden para disise Aarstider flere Individer ad Gamgen paa et enkelt Sæt Liner, ligesom om Vaaren.

I enkelte Aar synes de at erholdes talrigere, end i andre;

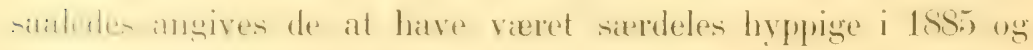
i 1890. Af Fiskerne bortkastes de som værdiløse, og bringes

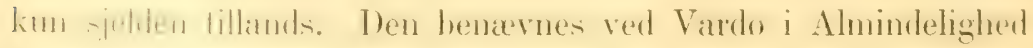
Ulvefisk.

1 Til Fangsten afden store Havtorsk, der i Vaarmanederne soger ind fra Dybderne for at fraadse i Stimerne af Mallotus villosus (Lodde), som nu kommer under Land for at yngle. 
Storrelse. Som ovenfor nævnt, erholdes paa Linerne saa-

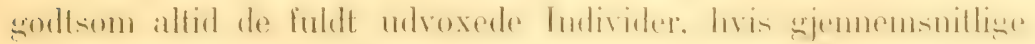
Storrelse er omkring $600^{\mathrm{mm}}$, eller noget derover.

Forholdsvis faa Individer have havt en Storrelse over $700^{\mathrm{mm}}$,

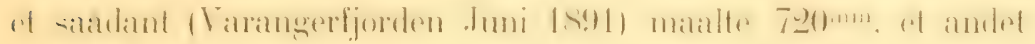

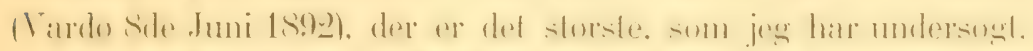

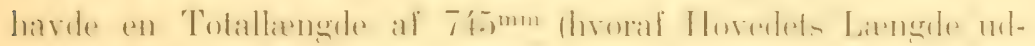
gjorde $\left.160^{\mathrm{mm}}\right)$.

Individer med en 'lotall. af under $500^{\mathrm{mm}}$ ere allerede sjeldnere, og blandt det store Antal af næsten $50 \mathrm{St.}$ som jeg har

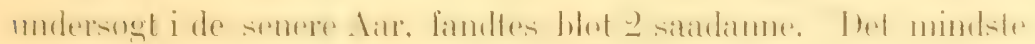
af disse (Varangerfjord 19de Mai 1890) havde en Totall. af $465^{\mathrm{mm}}$. Farven hos detle Individ udviste noiagtigt de samme kjedelignende hvide Tverbaand, som hos de fuldt udvoxede.

Fiskerne meddele imidlertid, at de ogsaa leilighedsvis erholde de noget mindre Unger („af en Fods Længde“).

Forplantning. De fuldvoxne Individer af $L$. esmarkii have, som ovenfor nævnt, været erholdte i saagodtsom alle Aarstider, og det kan neppe betvivles, at Arten ogsaa yngler under Kysten.

Ingletiden falder sandsynligvis i Aarets forste Maaneder. De fleste Hunner, som erholdes om Høsten og Vinteren, have været rognfyldte, og Rognmassen, der tilsidst stærkt udspiler

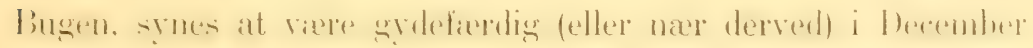
eller Januar. Et Ind., der var fanget 30te Mai 1882, var saa-

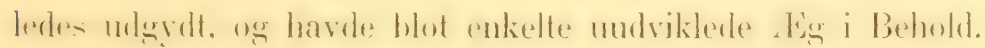

Dog synes Yngletiden ikke at være helt constant. Et Ind., fanget ved Vardo 13de Juni 1884, havde allerede store $\mathrm{Eg} \mathrm{i}$

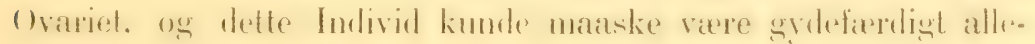
rede om Hosten.

Antallet af $\mathrm{Eg}$ er ikke synderlig stort, og overstiger neppe

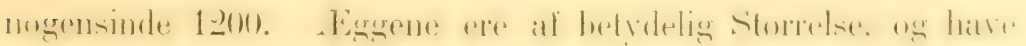
en Diameter af omtr. $6^{\mathrm{mm}}$.

Kjonnene have hos de fangne Individer været omtrent lige-

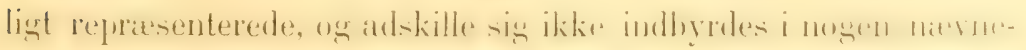


verrlig Grand $\mathrm{i}$ Strmedse eller Udseende. Som ved en tidligere Iteilisher muddelt ${ }^{1}$. have Hanneme dog et relativt storre Hoved (m) Humnerm. ligesom Tanderne ere stærkere og Tandrækkerne litngere bus Hannerne, end hos Hunner af samme Storrelse.

Føde. Hos de fangede Indiv., hvis Ventrikler endnu have indeholdt ufordonet Fode, har deme i Regelen bestaaet af lavere Sudyr, iner Echinodermer. Saaledes fandtes hos et Ind. (Vard, ב-4142 (). 1S82) knuste Skaller og hele Exemplarer af Echinus norrefficus; ligeledes har jeg seet hos Exemplarer fra samme Localitet (Varangerfjorden) hele eller kjendelige Levninger af -Autedon sarsii, Ctenorliscus crispatus. og Ophiacantha bidentata.

I Ios \& Individer, aile fangede paa samme Linesæt ved Vardo sile Inni 1S92, vare Ventriklerne fyldte med Unger af Strongylocentrotus drobachiensis, samt forskjellige Bunddyr (hvoriblandt et Expl. af Homera lichenoides).

I sin Levemaade synes den saaledes $\mathrm{i}$ det hele at stemme overens med Anarrhichas-Arterne (især A. minor).

\section{Lycodes sarsii, Coll. 1871.}

Udbredelse. Af Lycodes sarsii er for Tiden omtrent 19 Individer kjendte. hworaf de 18 (deri indlefattet 'Typ-Individet) '. fundne ved de norske Kyster. Disse Individer repræsentere i en uafhrudt Række Artens Udvikling fra Ingel-Stadiet op til det kjonsmodne Individ.

Ihet storste hidtil erholdte Individ har dog hot havt en Lemgde

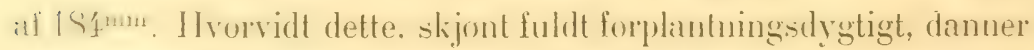
don yelente Griendse for Artens Lidvikling, er endnu ukjendt.

\section{Diagnose.}

Legemsbygningen langstrakt (Subgenus Lycenchelys, Gill 1SS4).

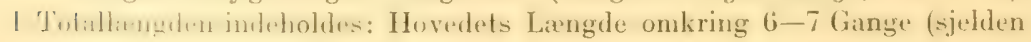
lidt over eller under), Legemets Hoide i Regelen 12-14 Gange (undertiden indtil 17), Dorsalens Afstand fra Snudespidsen 4-4 $\frac{1}{2}$ Gange, Kroppen (Legemet foran Anus) $3-3^{1} / 2$ Gange (hos enkelte Ind. indtil $3^{3 / 4}$ ).

2 Nyt Mag. f. Naturv. 29de B., p. 75 (Chria. 1885). 
Farve. Regelmessige 'l'verbaand mangle. Farven iovrigt varierende efter Alderen. Sman Unger ere ensfarvede. Noget storre Unger oventil graabrune med uregelmassige brunsorte Tverpletter og Skygninger over liyggen og Inilen; Lndersiden hvilgul (uplettet); en sortagtig T'vilemellem Oie og Snudespids. De aldre (fuldt udfarvede?) ensartet morkt graabrune, med utydelige Skygninger nedad Siderne, men uden Pletter eller Baand.

Sidelinien lar (ventral), utydelig.

Skjalbeklaed ningen diekker (hos de a ldre. Ind.) hele Lenemet, undtagen Hovedet, Nakken og Pectoralerne; spredte Skjæl ogsaa paa Dorsal og Anal.

Tander i Kjeverne, paa Palatinbenene og paa Vomer.

M. B. 6. Straaleantal: D. omtr. $116(+$ C. 7); A. omtr. $110(+$ C. 7$)$; P. 15 eller 16.

Storrelse. Det storste hidtil fundne Individ $184 \mathrm{~mm}$.

Hab. Skagerak; Christianiafjord, Arendalsrenden, Hardangerfjord, 'Trondhjemsfjord, Foldenfjord, Salten.

Historie. Denne Art blev oprindelig beskrevet efter et lingel-Individ, med en Totall. al $44^{m m}$, optaget i Ilardanger-

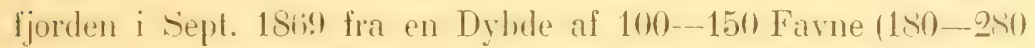
Meter); et lignende Yngel-Individ, med en Tolall. af $47^{\mathrm{mm}}$, optoges red Aprelvar i Nandalen 13de Aug. ISS4 fra en Dybde

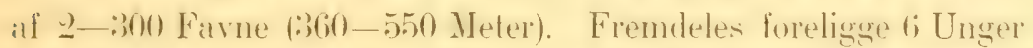
i Mellem-Stadied, med en Totall. af 5 (b-12010m. alle optagne i Trondhjemsfjorden i Aarene 1882 til 1896.

De næste Individer, 8 i Antal, bleve optagne under de practisk-videnskahdige Luderongelser af vore sallvand-Fi-kerier. der i Sommeren 1897 bleve drevne i Skagerak og Christianiafjorden af Dr. Petersen og af Dr. Hjort.

Alle disse sidste Individer tilhore Artens mere fremskredne

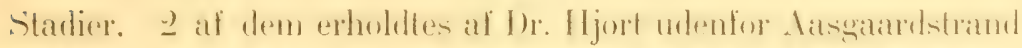

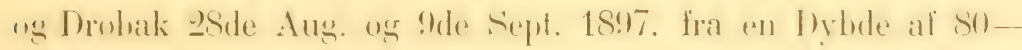
100) Favne (145-180 Meter); disses Totall. vall 116 og $144^{\mathrm{mm}}$. begge hefandt sig i et Overgangsstadium, der var horskjelligh frat de tidligere kjendte Ungdomsformers.

De ovrige optoges af Dr. Petersen, dels i Dybvandsrenden

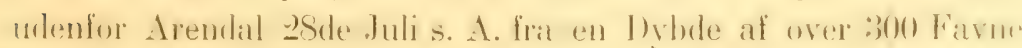

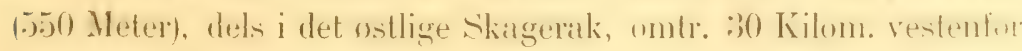
Bohuslen. Alle disse, som havde en Totall. af 126-184 $4^{\mathrm{m}}$,

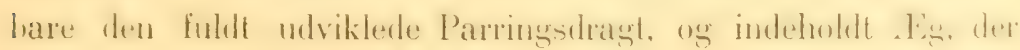


vare sin fulde Udvikling nær. Disse Individer kunne saaledes maaske antages at have naaet sit endelige Udseende.

Endelig ere i de sidst forløbne Aar tilkomne 2 unge Indi-

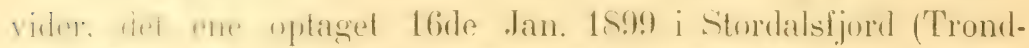

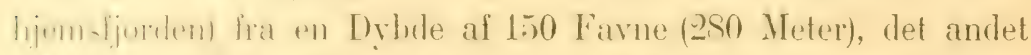
i Xordfulden i Salten 6te April 1900 (Dybrlen 5:30 Meter). Begge

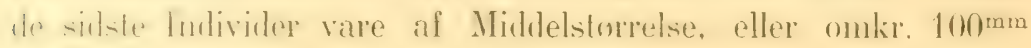
lange.

L. sarsii og dens Udviklings-Stadier er i 1898 nærmere omhamdlef os afbildet af Forf. i Videnskabsselskahets skrifter for det nevnte Aar'.

De 2 mye Individer fra de seneste Aar havde folgende Mกล:

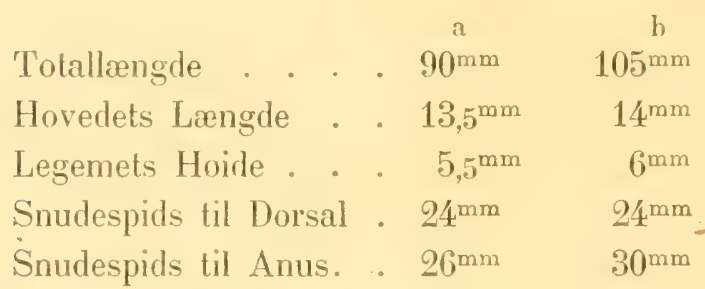

Begge tilhøre det Stadium, som i den ovenfor nævnte Afhandling er heskrevet som No. 4. Hoi det mindste Individ ere de morlie og uregehmasige Trerpletter paa Legemet tilstede. nu+n utrdelige, og firmden langs Dorsalen hegruder netop at farves mork; det storre er allerede mørkfarvet, undtagen i en Milltribe langs henad Legemet, der er Iys. Skjathekladningen er her complet, undtagen i den lyse Midtstribe.

Udbredelse. Den Dybde, paa hvilke L. sarsii i Norge lindil har vieret erholdt, har varieret mellem 80 og 300 Favne

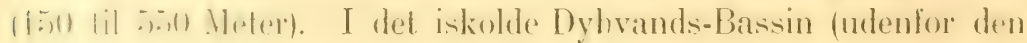
continentale Platform) er L. sarsii hidtil ikke paavist.

De hidtil foreliggende 19 sikre Individer ere optagne paa

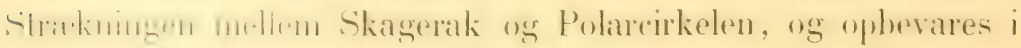
Nuseerne i Christiania, Bergen og Kjobenhavn.

Contributions to the Kinowledge of the Genus Lycodes, Reinh. I. Lycodes sarsii. Coll. (Skr. af Vidensk.-Selsk. Chria. 1895. I. Math.-Naturv. Kilasse, No. 1). Med Pl. I-II. 


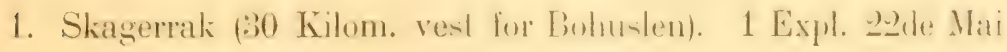
1897; Totall. $88^{\mathrm{mm}}$.

2. Arendals-Renden. 6 Expl. 28de Juli 1897; Totall. 126$184^{\mathrm{mu}}$.

:3. Christianiafjord (Aasgandstrand. Mrobak. 2 kxpl. zsile Aug. og 9de Sept. 1897; Totall. 116 og $144^{\mathrm{mm}}$.

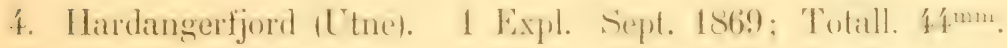
(Typ-Expl.)

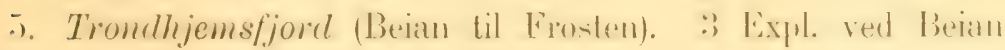
31te Aug. 1882; T'otall. 57-62mm.

3 Expl. ved Frosten 15de Aug. 1895, og 3die Aug. 1896; Totall. $57-120 \mathrm{~mm}$.

1 Expl. i Størdalsfjord 16de Jan. 1899; 'T'otall. $105^{\mathrm{mm}}$.

6. Foldenfjord (Apelvær). 1 Expl. 13de Aug. 1884; Totall. $4^{\mathrm{mm}}$.

7. Nordfolden i Salten. 1 Expl. 5te April 1900. 'Totall. $90^{\mathrm{mm}}$.

Farve og Slijalbelilnduing. Farvetegningen undrogaar vasentlig. Forandringer under Individernes Vext, og er charatteristisk for hvert Alderstrin.

Den spæde Unge er ensartet graabrun langs Ryggen, og gulhvid langs Undersiden.

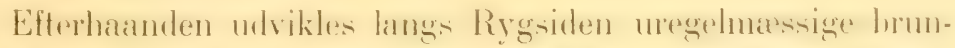
surte Treppletter, der sta skarph moul den nogel lysure bumbfarve. Senere udbreder Ryggens grablome Pigment sig ogsia lang- Analen, medens samtidigt de morkere Treppletter talw sig. iilet Bundfarven, hrori de ligge, i Regelen hliver morken.

Tilsidst er Legemet atter næsten ensfarvet overalt, morkt frata- eller gullorunt. kun med utydelige morkere Skigninger ned ad Siderne.

Saalertes foreligar i en hel Rakke te forskjellige MaldrStardier, hrer med sin diendommelige Farvetegning: samblidig hu-

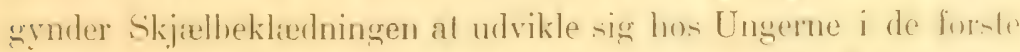
plettede Stadier, og fuldendes kort for den endelige Lathorving.

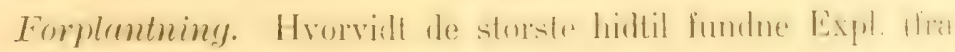

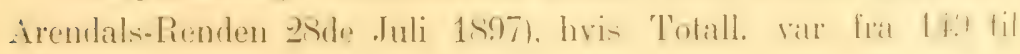


1S $4^{\mathrm{m} m}$, ere luldt udvoxede, er maaske tvivlsomt. Af de 4 Expl., som havde denne Storrelse, vare de 2 Hanner, 2 Hunner; hos

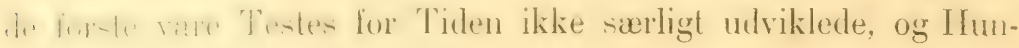
nerne havde umodne $\mathrm{Eg}$ i Ovarierne.

Et noget mindre Expl., hvis Totall. var $144^{\mathrm{mm}}$, og som opinsu untenfor Latogardstrand i Christianiafjorden i August 1597. wa on Han. hris Testes vare betydeligh storre og mere udviklede. end hos de ovennævinte.

lutte Imbivid havde endnu ikke anlagt de aldste Individers Fimr. medens andre Individer foreligge, som allerede ere urfarvede med en Totall. af $124^{\mathrm{mm}}$.

In er derfor sandsynligt, at Gydetiden for alle disse Indivirter vilute have indruffet $\mathrm{i}$ Vintemannedeme, $o g$ at Legemet muligens vilde til deme Tid have naaet en noget hetydeligere Størrelse.

\section{Fam. Gadidae.}

\section{Gadus morrhua, Lin. 1766.}

Torsliens Riologi hos os. Under de practisk-videnskabelige Tuder-ugelser af Norges Kyster og de tilstodende Havstrekninger, -rmin i Lubet af de seneste Lar med stor Fremgang have vierel drerne af Dr. IJjort, i Forening med flere yngre Videnskabsunend (1)r. Lahl, Dr. Nordgand, o. a.), ere en Raxke Erfaringer blevme rmmlu, som have kistet et nanten helt nyt Lys orer Torikens Idw. Liv-vilkaar, og samtidigt over de Naturforholde, hrorat 1. - torre og mindre Fiskerier, som tilsammen udgjore en af Landets Hovednæringsveie, ere væsentlig afhængige. ${ }^{1}$

En Fremstilling af disse Undersogelser og deres Resultater er meddelt i flere Afhandlinger og Skrifter, hvoraf de udforligste ere folgende:

Johun Hjort og Kunt Dahl, Fiskeforsog i Norske Fjorde, Chria. 1899.

Knut Dahl, Beretning om Fiskeriundersogelser i og om Trondhjemsfjorden 1898. (Det Kgl. N. Vid. Selsk. Skr. 1898, No. 10). Thjem. 1899. 


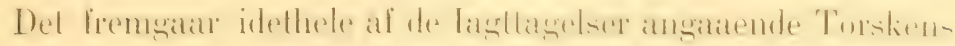
Livshisturie, som hidtil foredigge, al dens Lidvikling og liv i en

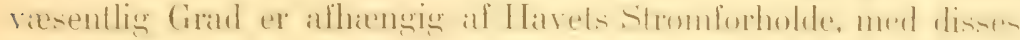

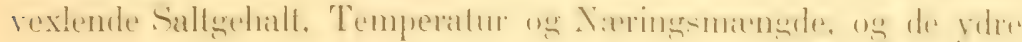

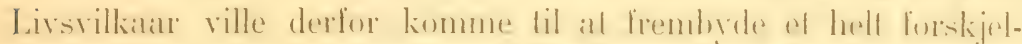
ligt Billede under de forskjellige Perioder i 'Torskens Liv.

Som saadanne Perioder kunne forst betragtes de 4 naturlige

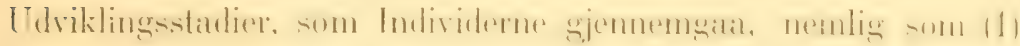
Eg, som (2) Yngel, som (3) Ung-T'orsk, og som (4) den voxne Torsk. Hertil komme som særegne Perioder (5) de store Næringsvandringer, samt (6) Ynglevandringen.

Som en egen Afdeling kan endelig betragtes (7) den statio. nære Stamme, Fjordtorsken.

1. Agget. Gjennem G. O. Sars' Undersogelser i SextiAarene er det, som bekjendt, constateret, at Torskens Rogn, hvis Idameter er 1,3 ${ }^{\mathrm{mm}}$, gjennemgan sin Lidvikling i llvilend. Tilstand nax (t)erfladen. Rognen gydes i Regelen fra . Iamuar til omkr. Midten af April.

Som Resultat af de under "Michael Sars"“ i 1899-1901

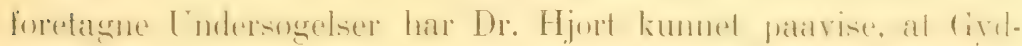
ningen i det store taged kun kinn finde. Sted para de flade Kive-

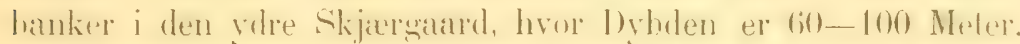

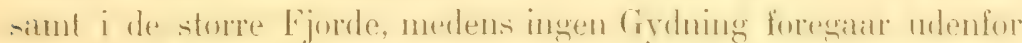

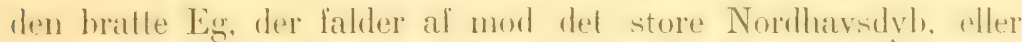
paa det grundere Vand.

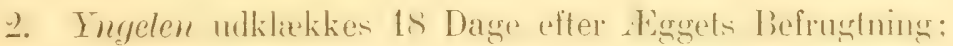
14 Dage gammel har den en Totall. af $7-S^{\mathrm{mm}} ; 1$ Maaned

O. Nordgaard, Contribution to the Study of Hydrography and Biology on the Coast of Norway, p. 12 (Bergens Museum. Rep. Norw. Mar. Invest. 1895-97). Bergen 1899.

Johan Hjort, Fiskeri og Hvalfangst i det nordlige Norge (Aarb: vedkommende Norges Fiskerier 1902, udg. af Norges Fiskeristyrelse, 1. Hefte), Bergen 1902.

For Danmarks Vedkommende er den samme Sag ved flere Leilig. heder ombandlet af Dr. Joh. Petersen, Chefen for den Danske Biolo. giske Station, som (i 1902) har meddelt Hoved-Resultaterne af sine Iagttagelser i:

C. G. Joh. Petersen, Torskens Biologi i de danske Farvande (Beretn, fra den Danske Biol. Stat. XI, 1900 og 1901, p. 3). Kbhvn. 1902. 


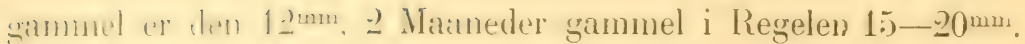
On Sunnerenti er lngelen omkring $50 \mathrm{~mm}$ lang; i IIostmaanederne, natal den er 5 - 6 Maneder gammel, er den bleven til sima Unger mat en Langde af 3-4 Tommer, eller fra $60-$ $100^{\mathrm{mm}}$ eller lidt derover.

Allerede i Midten af Sexti-Aarene havde Prof. G. O. Sars higgtiaget. at de drivende itg og Ingel undertiden af Havstrommene kunde fores langt bort fra Gydepladsene.

Ved en Ritkke indgaaende Undersogelser er Dr. Hjort kommen lil det Resultat, at hos alle de Fiskearter, der have pelagiske (Ilydende) Eg, driver i Sommermaanederne den storste Del af Liggente og Ingelen bort fra Gydepladsene og ud over Havet med de stromme, som paa denne Aarstid forer Kystrandet ud ha Land, ${ }^{1}$ og Torske-Ingelen ernarer sig her til ud paa Hosten af det rige l'lancton, som paa denne Tid udvikler sig i Kystvandet.

Eifter Aarenes vexlende Stromforholde kan Torskevngelen (on I'lanctun'et) saaledes i enkelte Aar drive langt tilhavs; i 1900) landt Dr. Hjort de smaa Torskeunger i 30 Miles Afstand udenfor Finmarks-Kysten.

Det samme Forhold finder i det hele ogsaa Sted i Fjordene. "g Ir. IJjort har paavist for Christianiafjordens, Dr. Dahl for Trondhjemsfjordens Vedkommende, at Fjordene i Sommermanne. derne: ere i det store laget blottede for Aarsingelen, skjont der 1. Ex. i den sidstuevnte Fjord paa flere steder i de indre Dele finder rige (iydepladse. Derimod vil man 1. Ex. i Skagerrak. Nind-resn, og langs den ydre Skjargard i Landets mellemst. the finde Torskeyngelen spredt satagodtsom overalt i de ovre Vandlag om Sommeren.

I I Dammark er Dr. Petersen allerede i 1892 bleven opmærksom paa dette Factum, og udtaler saaledes i Beretn. om den Danske Biolog. Station III, p. 5, (Kbhrn. 1893), at det har forundret ham under disse Undersogelser, ,at Ungerne af de pelagiske $\mathrm{Eg}$, hvilke sidste undertiden fandtes i sail enorme Mrngder i Frnø-Sund, ikke udklækkedes der, eller i ethvert fald kun vare til at paavise der rent undtagelsesvis. Dette Forhold gialdt nemlig ikke alene Torsken, men alle Fiskearter, der have pelagiske (svævende) $\mathbf{E g}$, i Modsætning til dem, der afsætte deres Eg paa Bunden." 
Helt uden Yngel ere dog ikke Fjordene om Sommeren. En Thel, men sandsynligris blot en ringe. Deel af de drivende tig. fil-

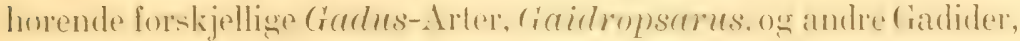
udklixkkes utvivlsomt i selve Fonden. og longelen vil her kunne undergaa sin videre Udvikling.

Saaledes findes jevnlig om Sommeren smaa 'T'orskeunger

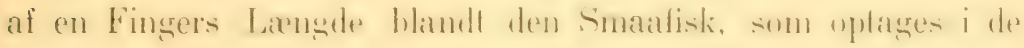
fimmiskede Garn medem (terme udenfor (haristiania, og den

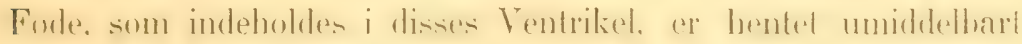
fra Fjordens Tangregion.

Om Hosten det forste Aar, naar Plancton'et efterhaanden dor bort, soge de smata pelagiske Unger, hris siomme-bine nu er mere udviklet, ned mod Bunden efter Næring, og de drives nu, væsentlig af Havstrommene, men ogsaa delvis ved egen Hjalp. atter mod Land. Hexumber kunne de ofte tratfes stimevis wer (imunderne (...Skaller") pra Bankerne. hror de ivrig ofterstrathes af Rovfiske on andre Havdyre, og hor dr tildels kumne give Anledning til et righ Fiske af Sei (r. rivens), som trabdate $\mathrm{i}$ denne Aate.

()fte tage Individerne under dette pelagiske Stadium sil T'il.

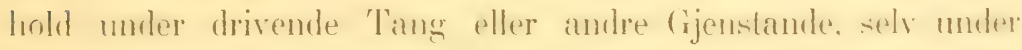
de store Manæeler (Cyanea), hvad der allerede i Sexti-Aarene havde vakt Prof. Sars' Opmærksomhed.

3. Ung-Torsk. Den storste Del af den om Hosten indsigende Ingel standser allerede ved de ydre Binker, og molergaar her sin videre Twikling nar Bunden mellem disse Pankers mere eller mindre rige Dyreliv, indtil de i 2-3 Aars Alderen begynder at flakke videre om efter Næring. Det Dyb,

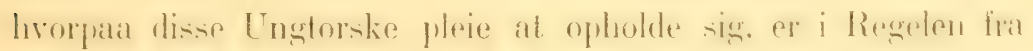
200- 400 Meter.

En Del af Yngelen soger sammen med de andre Ungtorske længere ind paa Grunderne, og trænger ind i Fjordene, hvor de tage Tilhold blandt Bladtangen ("Taretorsk").

Ungtorskens blivende Opholdssted er, som ovenfor nærnt,

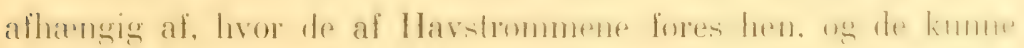
saaledes komme til at lande paa Steder, der ligge fjernt fra 


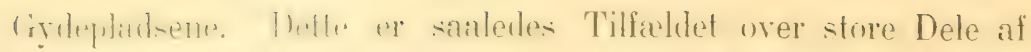

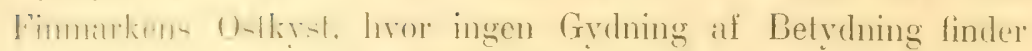
Sted, men hror Masser af 'T'orskeunger om Sommeren have sit Tilhold.

Th da le lillige hlive spredte orer forskjellige Drhder. lige

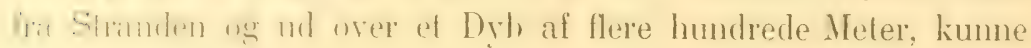

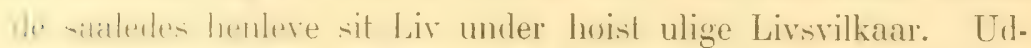
vilingen kan herlor blive hoist forskjellig, alt efter den vexlende 'Tilgang af Fole, on Individer af samme Aldersclasse kunne derfor være af ganske ulige Størrelse.

[ Lobet af Vinteren synes deres Væxt idethele at foregaa langsommere, og om Vaaren, naar Ungen er 1 Aar gammel, har den gjerne en Totall. af $100-200^{\mathrm{mm}}(4-8$ Tommer).

l,e ב-Aars ganle Torske have gjennemsnitlig naat en Totall. af omkring $500 \mathrm{~mm}$ (eller 18 Tommer). Det er denne Alders- Maris, der danner Ioveduassen under de store Naringsvandringer i Finmarken (Loddetorsken).

t. Then voxue Torsti. Have Niering-forholdene vieret nogenImnle gumtige, have de :' Aar gamle Individer i Regelen natet en Længde af omkr. $700^{\mathrm{mm}}$ (eller 26 Tommer), og kaldes i latudet: modlige Dele skrei. Den er nu forplantningalygtig.

Efter Gydetiden siger Skreien atter ud mod Dybet, hvor en Del synes at tage sit Ophold over de ydre Banker, hvor disse falde af mod de store Dyb. Men de synes tillige, ligesom Ungtorsken, at fore et omflakkende Liv, og de vise sig undertiden

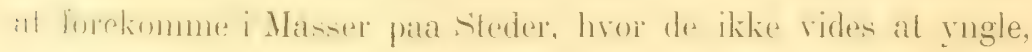

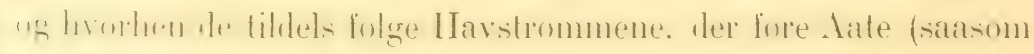
ved Spitshergen og Beeren Eiland).

Vuringsemertringerne. De "gandlige Nitringstandringer ere overordentlig vexlende fra Aar til Aar, og ere afhængige af en Flerhed af Naturforholde i Havet.

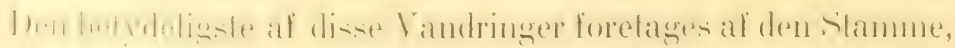

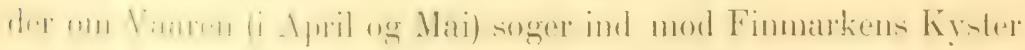
for at fraadse $\mathrm{i}$ de Stimer af Lodde (Mallotus villosus), som paa denne 'Tid stiger fra Ishavets Dyb op under Land for at gyde. 
Som ovenfor navnt bestaar Hovedmassen af denne "Loddetorsk" af yngre, omkring 2 Aar gamle Individer, for en mindre Del af storre gydefærdig eller udgydt Skrei.

Det Dyb, på hvilket Loddetorsken pleier at fanges, er fra 400 Meter $0 g$ op til 40 Meter. Fiskeriets Udbytte er dog

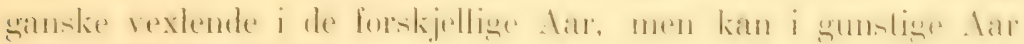

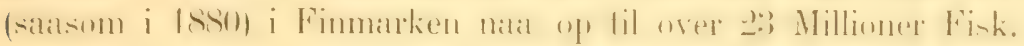

Naar Lodden efter endt Gydetid atter drager tilhavs, følge

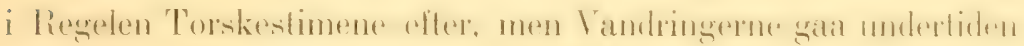
mod Nord, undertiden ostover. En Del af Masserne blive dog staaende Sommeren over nærmere under Land, og kunne her

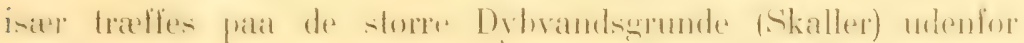
Kysten.

De synes dog idethele nu at føre en omflakkende Tilviarelse, og deres hovedsagelige Tilholdssted senere a tmdnu neppe kjendt. I det store taget vil sandsynligvis deres Bevægelier vere afhangige af hestemte strom- og 'T'emperaturforholde i Havet.

Ligesom Yngelen under sit pelagiske Liv idethele er afharmerig af Kistrandet. og forsvinder, hror dette monder de kolde.

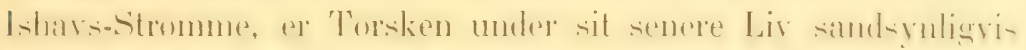

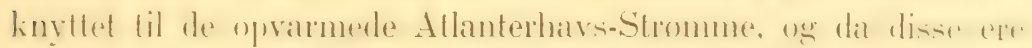
Vexlinger underkinstede $i$ de torskjellige Aar, kumme 'Torakestimerne ligeledes være helt vexlende $\mathrm{i}$ sin Optræden.

6. Inglevandringerne. Den paafolgende Vinter, naar Tor-

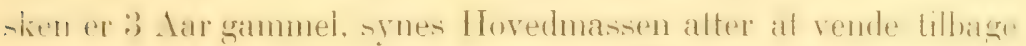
til Bankerne. Loor den tidligere havde: Tilhold. Itermuler nati

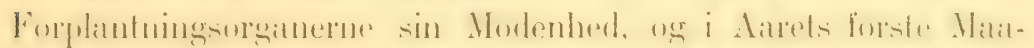

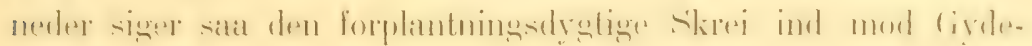
pladsene for at gyde.

Gydningen foregaar overalt langs Kysten, men hovedsage-

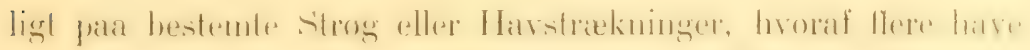
værel kjendte som Gydepladse fra de xldste 'Tider. I Landets

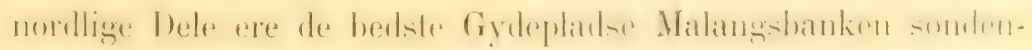

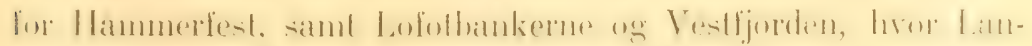
dets storste Torskefiskeri, Lofot-Fisket, som bekjendt, drives. 
Mesuden finde- rige Ciglepladse paa Bankerne udenfor Romsdals Amt.

(1-knful Ilammerfest har ikke kunnet paavises nogen storre Gydeplads hos os.

Efter Gydetidens Slutning søger Skreien atter ud over Hawe; mkelte standse paa Kóytbankerne, andre begive sig bragere ud paa Dybet, og kunne nu traffes i betydelig Afstand fra Land.

lirorrill det er Hovedmasserne af den udgrodte Skrei, der pair Ienne Maade tager sit 'Tilhold ude paa det store Nordhars. dyh. Mre on de fleste af disse standse ved de bratte Egge, er endnu ikke fuldt oplyst.

7. Fjordtorsken. Som ovenfor næunt, fores de i Fjorden writte Eg af Strommene tilhavs, og Yngelen undergaar sin forste ITwikling i Fjord-Mundingerne, eller tildels langt udenfor disse. (In Insten drives Aarets Yngel, i Selskah med weldre Aarsrasser, ved indgaaende Stromme (der ogsaa fore andre pelagiske Dyr, f. Ex. Cyanea capillata med sig), atter ind i den indre Skjwergaard eller i Fjordene, hror de oftest tage sit Tilhwlil paa tanghevoxede Steder (blandt Laminarierne), tildels paa forholdsvis ringe Dyb.

Vistnok kunne i Fjordene alle Aldersclasier træffes Aaret rundt, som en mere eller mindre stationæer Stamme; men Hovedmar-su synes ogsaa her at udvandre om Vaaren og vende tillant on Insten. I Regelen ere disice stationære (og her gyHentul Fordtorsk i den indre Skjærgaard kjendeling ved sin rodbrune Farve, medens Havtorskens Farve er graa. ${ }^{1}$

Tiskrirme. Landet samtlige Torskefiskerisr heskjaftiger Aar om andet 90-100,000 Mand.

1 At den rodbrune Farve dog ikke er nogen arvelig Character, og saaledes tilhorer en bestemt Race, men er afhangig af Individernes len. gere eller kortere Ophold i Tangregionen, er ved directe Forsog paavist af Dr. Joh. Petersen, som $\mathrm{i}$ Lobet af nogle faa Timer fik Individerne til at skifte Furve efter Arten af Opholdsstedet. (Beretn. fra den Danske Biologiske Station. XI, 1900 og 1901, p. 15, Kbhvn. 1902.) 
Ifolge de officielle Opgaver give alene de store Fiskerier al

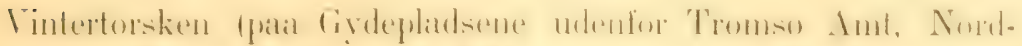

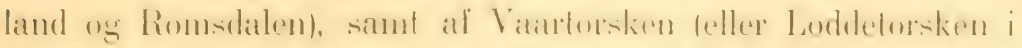

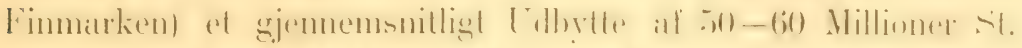

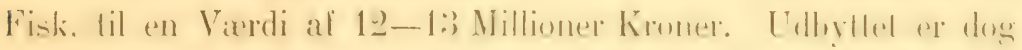

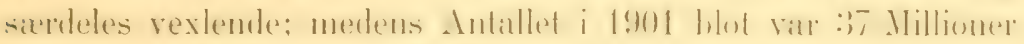
St., var det i 1894 over 70 Millioner.

Det storste af disse Fiskerier er', som ovenfor næunt, Vinter-

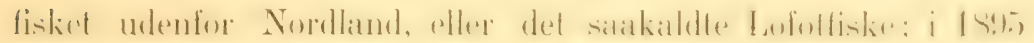

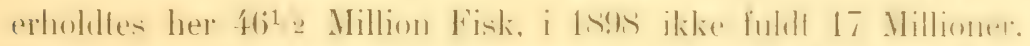

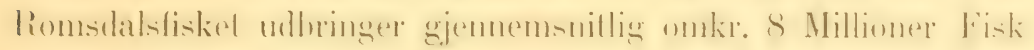
aarligt.

Loddefisket (Vaarfisket) er ligeledes vexlende; Udbyttet er i Gjennemsnit omkring 15 Millioner St. (i 1880 var det, som ovenfor nævnt, 23 Millioner, i 1896 blot $9^{1 / 2}$ Million).

Agn. Til Agn bruges under de store Torskefiskerier hovedsagrelig Sild, Lodde, Blaeksprut 1 Ommalostrephes todumst, simt

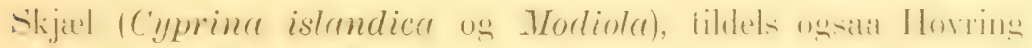
(Cancer pagurus).

Fode. Angaaende 'T'orskens Næringsforholde hos os el' der'

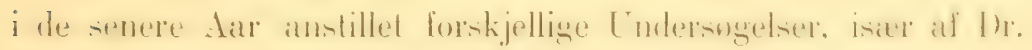
Nordgaard, Chefen for den Biologiske Station i Bergen. ${ }^{1}$

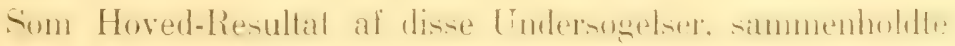

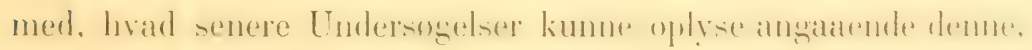
fremgaar følgende:

Yngelen nærer sig hovedsageligt af Plancton, især af Larver al Copepoder, Vermes og Echnodermer, delvis og -iali af de mindre Entomostraceer, saasom af Calame, Oithona, o. a.

Smaa Unger begynde at forlade den pelagiske Fode, naar de ere $70-80^{\mathrm{mm}}$ lange, og ernære sig senere væsentlig af Entomostraceer og andre smaa Crustaceer; snart begynde de ogsaa

1 Dr. Nordgaard har, foruden i flere mindre Meddelelser, omlandlet dette Emne (i 1899) i den p. 19 angivne Afhandling. 
at tage grovere Næring, saasom Annelider og spæde Fiskeunger.

Hos Aarsungerne om Høsten findes oftest i Ventrikelen smaa Crustaceer; hos en Del Exemplarer med en Totall. af

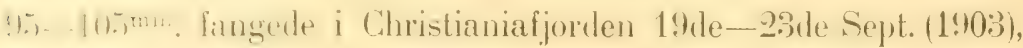

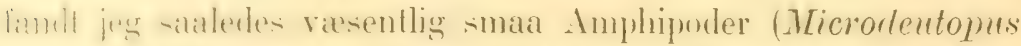
ammmalus. Ciammarms locusta, Apherusa bispinosa, og Mrsi小er. siml sman Annelider; ef Expl. havde i Ventr. et fuldroxent Lixpl. af Myctiphanes norvegica, et andet en Mrngde unge Caprellider (Proto pedata). ${ }^{1}$

Ilus en Del atrisgamle Unger, fangede mellem ()erne udenfor ('hristimia 2ude April (190:3), fandt jeg folgente Næering.

Hos de mindste af disse Unger, (Totall. $80-120^{\mathrm{mm}}$ ), var Finden endmu tildels pelagisk (Temora, blandet med Irlya); hos de wrige fandtes vasentlig Bundformer, nemlig Tang-Copepoder Hharpacticus. Thalestris), eller smaa Fiske-Unger (Gubier). De -torre: Unger rTotall. 120-150 () marus locustre, unkelte Hippolyter, Eunicer, eller robius-Lnger.

De aldre Individers Fode bestaar udenfor de Tider, da de hefinde sig paa de store Nierings-eller Ynglevindringer, hoved. rageligh af sardanne lyreformer, der have sit 'Tilhold paa eller nærved Bunden.

som Torkens Inovednuring kan ansees forkjellige Crustarexte af Dexapodernes ()rden (Pandalus, Hippolyte ug. CrangonApter. Cialatheer, Hyas, unge Cancer patguras, Carcimss o. a.).

Hexulen tages i stor Udstrixkning Echinodermer, især Ophi-

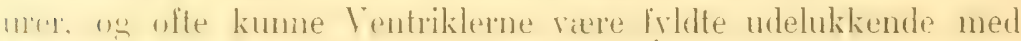
1. Hx. ")hiopholis aculerta. Ofte tages ligeledes Holothurier

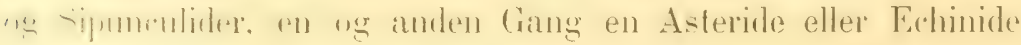
(Cribrella, Solaster, Echimus).

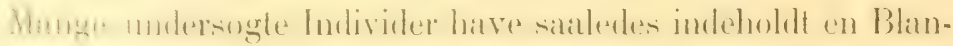

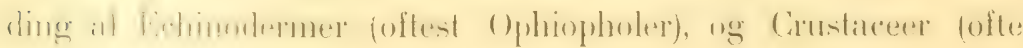
alene Galatheer).

Ved den noiere Bestemmelse af den i Ventriklerne indeholdte Næring har jeg havt on beredvillig Hjælp af min Ven og Collega Professor G. O. Sars. 
Endvidere tages Muslinger og Snegle, samt Annelider, de sidste $\mathrm{i}$ stor Udstrækning, Af Bucciner kumne ofte store Exemplarer findes hele i deres Ventrikel, ligsom af Pecten-Arter og andre Mollusker.

Ikke sjelden tages ligeledes Actinier og Ascidier, samt andre fastsiddende Invertebrater.

Af Fiske efterstræbes ligeledes især Arter, der have sit Tilhold nær eller ved Bunden, saasom Cottus-Arter, samt disses

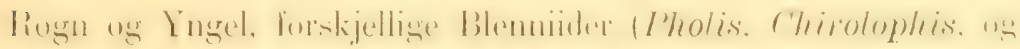

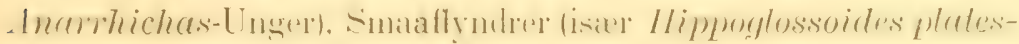
soides), fremdeles Liparis-Arter, og flere andre.

Fiskearterne ere iøvrigt noget forskjellige efter Localiteten. I Finmarkens Fjorde og ved de store nordlige Fiskevær inde-

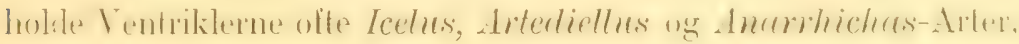
de sidste af Størrelse, som kan nærme sig en halv Meter.

Lang- Vestkysten finder ikke sjelden store Klumper af hingnklasen af Cyclopterus lumpus i Torskemaver.

I de mellemste og ovre Vandlag efterstræbes især mindre

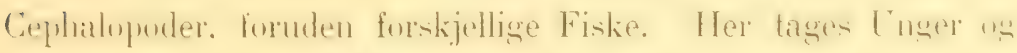

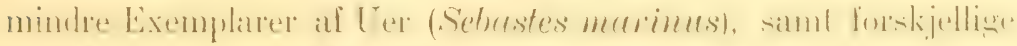

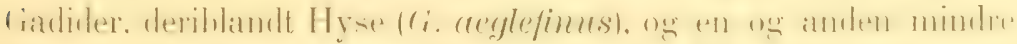
Torsk. Ligeledes følge de jevnlig Stimerne af Sil (Ammodytes), og kunne ofte fylde sin Ventrikel alene af denne Art.

Blandt Blækspruterne, der synes at være en søgt Fode, tages

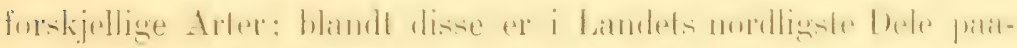
vist den arctiske Gonatus amoenus.

Af anden fritsvommende Fode kan nævnes grovere Plancton,

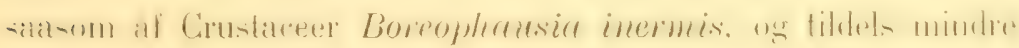
Crustaceer, ligesom der haves Exempel paa, at Torsken har

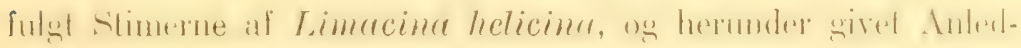
ning til indbringende Fangst.

Som en Hærkelighed omtaler Dr. Nordgaard, ${ }^{1}$ at han tlere Gange i Torskens Ventrikel har fundet en lysende Ostracode (Cypridina norvegica).

1 Contribution, etc. p. 17. 
Under Nærings-Vandringerne, naar de store Indsig mod lanul af sild eller lodke foregar. fraadse Torskene i disses Stimer. o hente pan deme Tirl næsten udelukkende sin Forle herfira.

Ilos at Expl. af Middelstorrelse, fanget ved Rodo i Helgeland i Milten af April (1903), fandtes saaledes 41 St. Smaasild.

Inder ef Vaarsildfiske red Bremanger i Marts 189:3 undersughe Dr. Nordgand ontr. 200 Torske-Ventrikler, og fandt det halve Antal fyldt med Vaarsild, det halve af Sildens Rogn; med den sidste fulgte Alger, Skjaxl, Sand, og andre Gjensiande fra Bunden. Blandt Sildene fandtes Exemplarer med en Totall. af indtil $280^{\mathrm{mm}}$.

Ilos andre Individer fandtes ved samme Leilighed forskjellign Bunddyr, saasom Ophiurer, Bucciner, Sipho, Chiton. og flere andre Arter Mollusker.

I'nder de egentlige Yugle-Vandringer (saasom under Vinterfisket i Lofoten og paa Storeggen) er Ventrikelen ofte tom: men ogsaa under denne Periode tages leilighedsvis saavel srommende Fode (saasom Thysanopoder og Amphipoder), som Bunddyr af forskjelligt, Slags. Enkelte af de Individer, som Dr. Nortgarard undersogle under Lofotfisket i Marts 189 - (ved Reine), havde Ventrikelen fuldproppet af Tentakler af Holothurier (isar tilhorende en Ant Phyllophorns). Ligeledes fandtes enkelte E.hinider, Asterider, og andre Bunddyr.

If mere uregelmassigt forekommende Fonlemidler kmme nævnes en hel Række.

Blimdt de mange forskjellige Fiskearter, som udgjore Fode lus. Torsken, ere saaledes leilighedsvis ogsan fundne Arter, der lum lil de sjuldnere Besogere af vore Farvande. Blandt disse

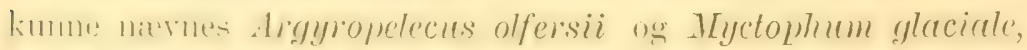
hvoraf flere af de ved de norske Kyster hentede Exemplarer

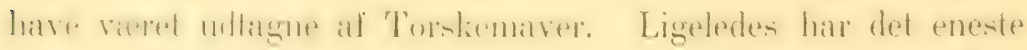
Expl. af Macmurus coelorhynchus, der er paavist i vore Far-

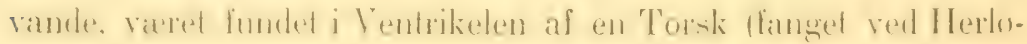
vær i Febr. 1842). 
Hos et Ind., fanget i Troldfjord i Lofoten 10de Febr. 1899,

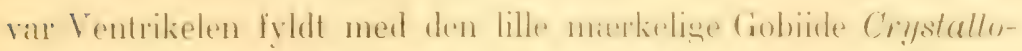

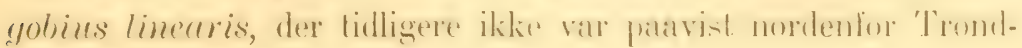
hjemsfjorden. ${ }^{1}$

Fremdeles kan paavises flere 'lilfæelde, hvori svommende

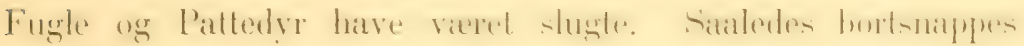

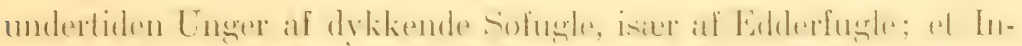
divid, fanget ved 'Trænen i Januar 1897, havde endog sogt at sluge en voxen Alca torda.

Hos et stort Ind., fanget i Ytre Eidsfjord, Vesteraalen (i

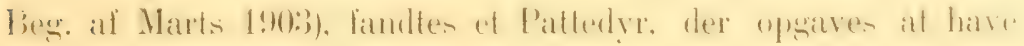
varet Ungen af en Oter (Lutra).

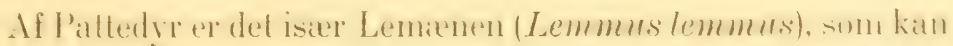

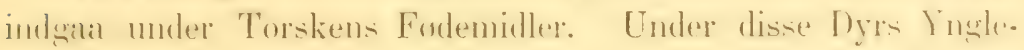
og Vandreaar svomme de ofte i Mængde over mellem Øer og

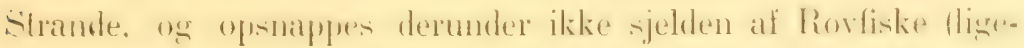
som i Indsoerne af Gjedde og Orret). Hos en Torsk, fanget

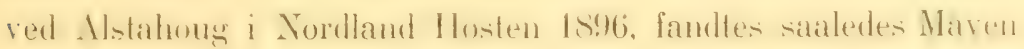

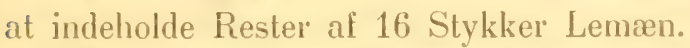

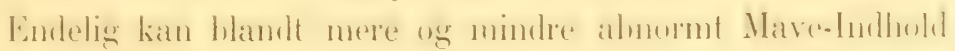
næevnes Stene, som ofte findes, tildels i stort Antal, i 'Torskens Ventrikel. I christiansumb Musemm opherares en Ratkle matrkelige Prover heraf. Hos et Ind., hvis Legemsvægt var 10

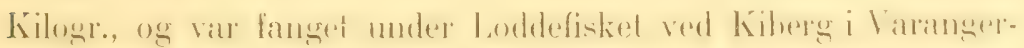
fjorden, fandtes Stene til en samlet Vagt af 700 Gram. I et

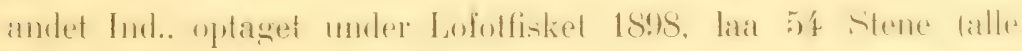
omkring valnodstore eller storre), hvis samlede Vægt var 900 Gram. Hos et Individ, fanget ved Kabelvaag i April 1897, fandtes 13 Stene til en samlet Vxgt af 205 Gram.

Den valdigste Sten fra en Skreimave opbevares ligeledes i

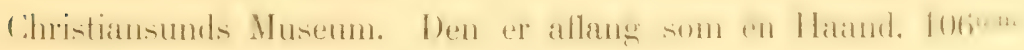
lang, $101^{\mathrm{mm}}$ bred, og veier 1770 Gram.

Det er sandsynligt, at paa disse Stene har oprindeligt et

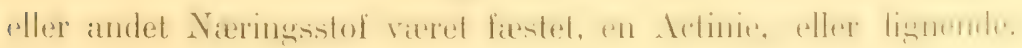

1 Forh. Vid.-Selsk. Chria. 1902, p. 69. 
Tor-kin- cimatighed herirker invrigh at den soger at sluge

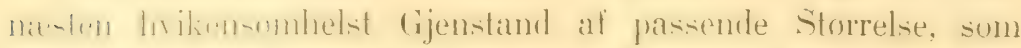

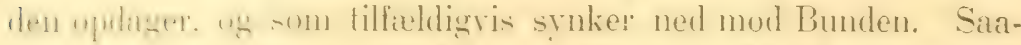

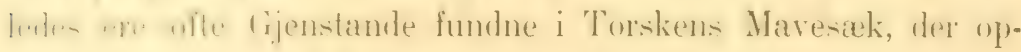
Jindelig ere tabte af Fiskerne udover Baadkanten. ${ }^{1}$

Varietet. Vaaren 1895 og 1896 toges ved Vardo flere lixemplarer af en Varietet, der var lysgul af Farre, og havde rnde ()ine: Finnerne vare ligeledes rode med sorte spidser. Exemjhareme vare surdeles store. indtil 1 Meter lange. (Meddeit af Bestyrer Dahl.)

Hermaphrodit. Tromso Museum har i de senere Aar modtaset ב Hermaphroditer, 1 Expl. fra Tysfjord Mai 1852. et fra Lyngenfjord 1896.

Ectoparasiter. Ved Bodo toges 1.ide April 1899 ? Expl. Her hegge havde paa Gjollerne en halvvoxen Mytilus fast.iddende (den ene tillige en Lernaea branchialis). Begge Expl. fuges paa samme Line. Muslingerne havle en Langde af 34 og $47 \mathrm{~mm}$. (Chria. Mus.)

1 Brotivund. I enkelte Flodmundinger. eller i Kystsoer, der red Hoivande staa i Forbindelse med Havet. stiger Torsken op lil det nasten helt ferskr Tand. Saaledes fiskes den ovenfor Fredriksistad i Elven lige indtil halveis op mod sarpfosien, eller omtr. 10 Kilom fra Mundingen.

I Saaledes mindre Redskaber, eller endog Knive; i Christiansunds Museum sees en Tollekniv med langt Blad, 205 $\mathrm{mm}$ lang, udtaget af en Torskemave under Loddefisket i Varangerfjorden. Dr. Nordgaard har endog fundet Appelsinskal i dens Mave, og Chria.-Museet fik i 1880 tilsendt et Par store Metalbriller (sammenboiede og uden Glas), der var udtaget af en Torsk ved Gjæsvær nær Nordcap samme Aar. 
Storrelse. Som extraordinart store Individer ere folgende omtalte $i$ de senere Aar:

\begin{tabular}{|c|c|c|c|c|}
\hline & $\begin{array}{l}\text { Total- } \\
\text { langde }\end{array}$ & Omkreds & Vregt & $\begin{array}{l}\text { Rognens } \\
\text { Vagt }\end{array}$ \\
\hline Eidsfjord 25de Febr. 1898 . & - & - & $27 \mathrm{Kg}$. & $7 \mathrm{Kg}$. \\
\hline $\begin{array}{l}\text { Tromsokysten 27de April } \\
1897 \text {. . . . . . }\end{array}$ & - & 一 & $127,5 \mathrm{Kg}$. & - \\
\hline Storeggen Dec. 1900 . . . . & $1270^{\mathrm{mm}}$ & - & $29 \mathrm{Kg}$. & - \\
\hline Lofoten Febr. 1894 . . . . & $1390^{\mathrm{mm}}$ & - & - & \\
\hline $\begin{array}{l}\text { Melbo, Lofoten, (15de Mai } \\
1903) \text {. . . . . }\end{array}$ & - & - & $30 \mathrm{Kg}$. & - \\
\hline $\begin{array}{l}\text { Henningsvaer, Lofoten April } \\
185 \% . \cdot . . .\end{array}$ & $1620^{\mathrm{mm}}$ & - & $33 \mathrm{Kg}$. & - \\
\hline Kijelvig. Pursanger Juni 1S5T & - & - & $36 \mathrm{Kg}$. & - \\
\hline $\begin{array}{l}\text { Melo, Helgeland 13de April } \\
1 \text { S96. }\end{array}$ & - & - & $36 \mathrm{Kg}$ & $10 \mathrm{Kg}$. \\
\hline $\begin{array}{l}\text { Brettesnæes, Lofoten } 23 \text { de } \\
\text { Marts } 1897 \text {. . . . . . }\end{array}$ & $1450^{\mathrm{mm}}$ & $10500^{\mathrm{mam}}$ & $36,5 \mathrm{Kg}$ & $6,7 \mathrm{Kg}$. \\
\hline Tanafjord 7de Juni 1SS7. . & $1530^{\mathrm{mm}}$ & $930^{\mathrm{mm}}$ & $3 \overline{T, 5 \mathrm{Kg}}$ & - \\
\hline Grashopen 13de Mai 1893 . & - & - & $40 \mathrm{Kg}$. & - \\
\hline Sorven Aug. 1889. . . . . & $1520^{\mathrm{mm}}$ & $960^{\mathrm{mm}}$ & $\mid 40,1 \mathrm{Kg}$. & - \\
\hline
\end{tabular}

I Affaldsdynge. I en Affaldsdynge, undersagt i 1899 af Conserv. Hellienen pala Krarnerig i Haakund (Jituleren), fandte-

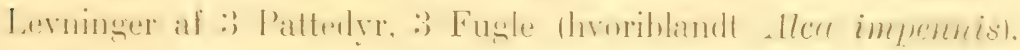
samt af Torsk. Af den sidstnævnte Art fandtes Dele af et Cranium.

Dyngen, hvis Høide over Havet er 18 Neter, ligger under

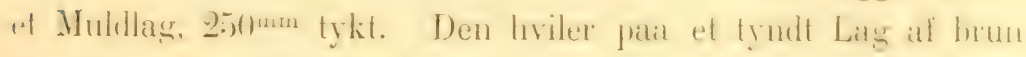

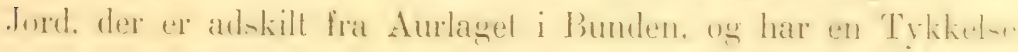
af omtr. $300^{\mathrm{mm}}$.

1 Alle disse Ben ere bestemte af Dr. H. WVinge, Kjobenhavn. (Stav. Museums Aarshefte 1900, p. 57, Stavanger 1900; Vidensk. Medd. Naturh. Foren. Kbhvn. 1903, p. 98. Kbhvm. 1903). 
Gadus virens, Lin. 1766.

Forplentuing. ()n Seiens Crydepladse og Forplantning foreligge endnu kun faa sikre Data fra vore Kyster.

Cigitetiden er noget varierende, men synes regulart at indIralle i Aarets forste Manneder, undertiden allerede i Januar. Civlepladiene opgives af Fiskerne at være Havel omkring de vilre Skjorgande, og de aabnere storre Fjorde i Landets nordlige Dele.

Allerede $\mathrm{i}$ December begynde hist $\mathrm{og}$ her Stimer af forplantningslygtige Individer at soge fra Dybet ind under Land rent te nordlige Fiskevar, og kunne herunder give Anledning til rige Fiskerier. Disse Individer grde saaledes endog tudligere, rmil de storre 'Torskestimer, der forst noget senere folge efter.

Som den normale Gydetid kan muligens ansees Maanederne Fehruar og Marts, idet der enduu i Februar træffes jevnlig Individer med fast Rogn og Melke. Saaledes fangede Prof. Sars lingel-Individer med en Totall. af 90_-30 $0^{\text {minn }}$ ved Skraaven (Lofulen) 4de Juni 1866; Yngel af samme Storrelse er ligelede: finget af Dr. Wollebæk ${ }^{1}$ ved Tananger (sondenfor Stavanger) ste-7de Juni 1899. Alle disse kunue muligens antages at have været 2-3 Maaneder gamle.

Andre Stimer syde forst i April, eller endnu senere. I Aquariel i Biologisk Station i Bergen legede saaledes, ifolge Dr. firieg, i 1s9\% en Del :3-anrige Individer i April; og jeg har flere Ciange paa forskjellige Steder ved Kysten fundet Yungel. for hvilken figdeticen neppe kan have indtuffet tidligere, end i April eller Mai.

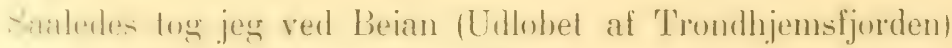
den 4de Juli 1875 Yngel, hvis Totall. endnu blot var $21 \mathrm{~mm}$; nugel hum var en Del longel, som jeg optog i Porsangerforden 4 de Juli 1876, og hvis Totall. var $38-42 \mathrm{~mm}$.

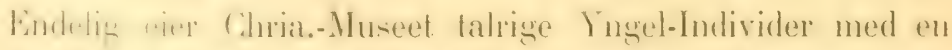

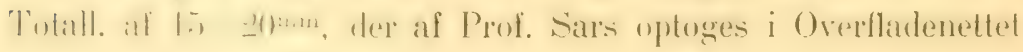

1 Rep. Norw. Fishery and Mar. Investig. Vol. I, p. 112. Chria. 1900. 


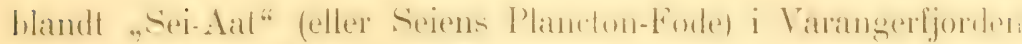
sile dus. 1879. Her har Grideliden matake forst indtrulfel a Juni,

Ators-Ingelen. I Sommermannederne naxmer Aars-Yingelen

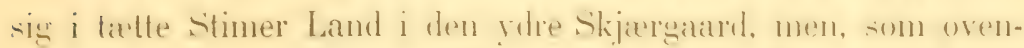
for nævnt, kunne Stimerne ofte være ulige udviklede.

Den 26de Juni 1896 iagttog jeg ved Loppen i Finmarken

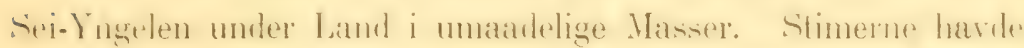
herunder sit Tilhold aver Laminaria-sikovene ved de kippe-

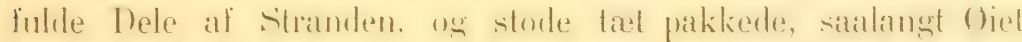
kunde naa dem fra Land. Alle Individer havde her en jevn Totall. af $60-65^{\mathrm{mm}}$.

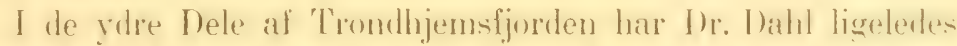

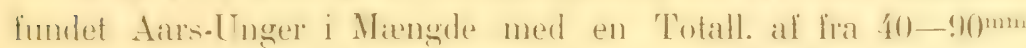
nmkr. Begyndelsen af Juli (1S!S). Det er sandsynligh, at alle disice Lnger have varet umkring f Manneder gamle, og at liognen har været gydt i Februar eller Marts.

Engernes Toring. Seien forer idethele en pelatgisli lavemate, idet den regulart har sit Tilhohl i de mellemste og mo

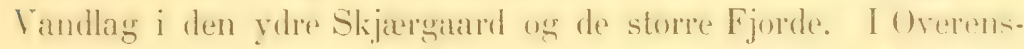
stemmelse hemed udgion dens Naring hovedsageligh Overlladedyr. Disse hentes for en stor Del fra Plancton eller de stimevis

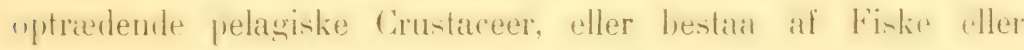
andre svømmende Sodyr.

I Modsætning til G. aeglefinus og G. morrhua tager idethele Seien neppe nogensinde sin Føde fra selve Bunden.

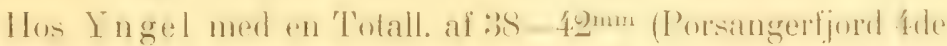
Juli Lsiti). der antagelig var onkr. :3 Manneder gammel, fandl

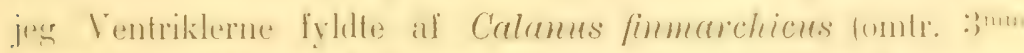

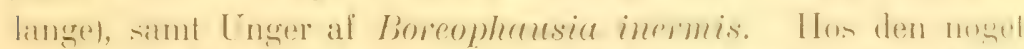

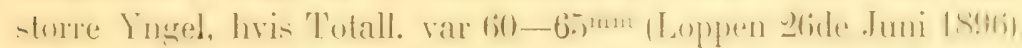

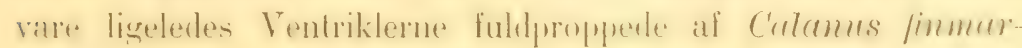
chicus.

I en Afhandling „Om Seiens Væxt og Aate" (Bergens Mu-

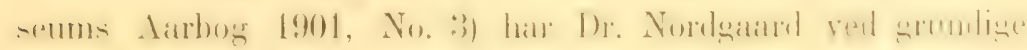

Virl.-Selsk. Forh. 1903. No. 9. 


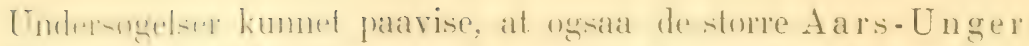

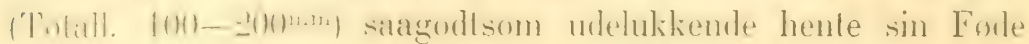
fra det drivende Plancton, især af de storre Copepode-Arter.

.li -ikulanne P'lancton-Former kunne Ventriklerne indeholde

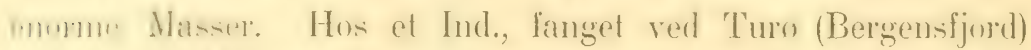

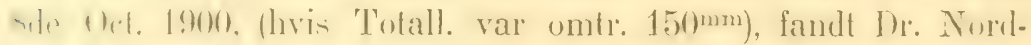

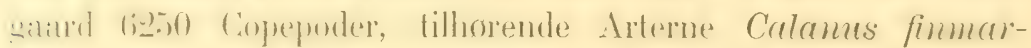
chicus. Centropages typicus, ag Anomalocera pattersoni.

B Bindt andre Plancton-Former, der intgaa i Ungernes Nixring. kimme niernes Chatopoder; af disse har Dr. Nordgaard funtet Singilla bipmuclala i stort Antal hos Individer, fangede ved Bergen 31te Oct. 1900.

() i stor Lidstrekning af Seiens Unger, niar denne Art Plancton netop er tilstede.

Hror Plandonet mangler eller er sparsomt tiktede, saitsom i Vinter- tler Vaa-Naanederne, tage Aars-Ungerne Ophold i Tangregionen (over Laminarierne), hror de ernæere sig af Amphipuder, Isonoder, Ostracoder, og Yngel af Mollusker, tildels ogsaa at Smaafiske.

Sialedes indelouldt af 3 Unger, ned en Totall. af $145-160 \mathrm{~mm}$, -rom jege udtog af et Slim, fanget udenfor Moss 30te Sept. 1s?1. det mindste Expl. en hel Gobius mimutus (hvis Totall. var flima): de to orrige havile Ventriklerne fuldproppede af littorale Hydroilen (Lafö̈a), sant enkelte: Unger af Mysis inermis, "gg Dele af Nereis.

De celdre Individer soge sin Næring dels i de grovere

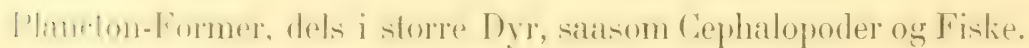

De betydelige Fiskerier af denne Art, som finde Sted om

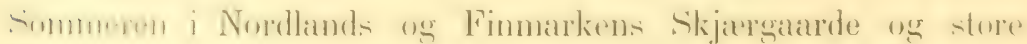

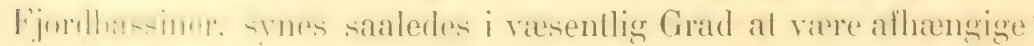

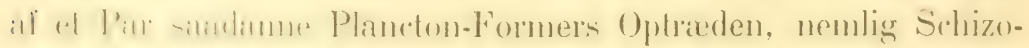

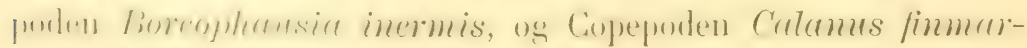

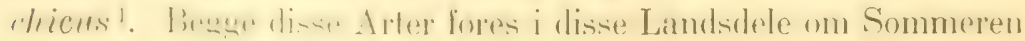

1 Forh. Vid.-Selsk. Chria. 1879, No. 1, p. 66. (Chria. 1879). 
af Strommene i umaadelige Masser om i de ovre Vandlag, og

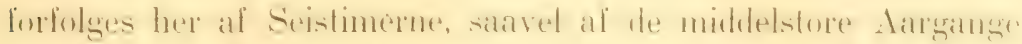

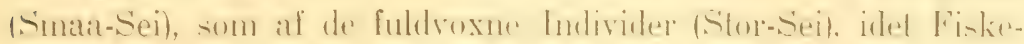
stimerne fortrinsvis soge hen og holde sig paa Steder, hvor

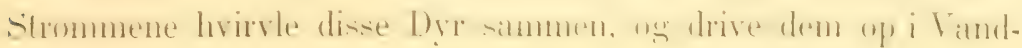
skorpen ${ }^{1}$.

Af andre Crustaceer, som i disse Egne gaa ind under "SeiAaten", og saaledes jevnlig findes i Seiens Mavesæk, kunne

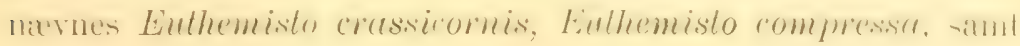
Parathemislo oblivia.

I de Dage, hvori de nævnte Crustaceer mangle, ernære Stimerne sig nolturflig af Fiske eller enkelte andre sombr. Sililedes har jeg i l'orsangerljorden under de store Físlierier i vince

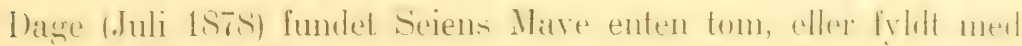
lingel af Mallotus villosis, sild, eller ned tmmorlytes-Linger. Ligeledes tage de leilighedsis Unger af Torsk, Ilrae IG. arolefimus), eller Unger af sin egen Art.

Som Prover paa Ventrikel-Indholdet hos Individer, der harve været fangede paa Dage, hvori Sei-Aaten har manglet, kan saaledes folgende anføres:

Hos et Ind. fra Tromsosund Juni 1896 fandt Capt. Juel

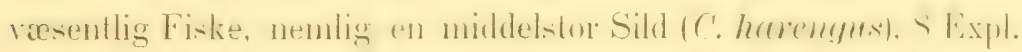

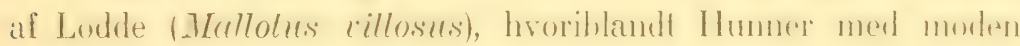
Rogn, 1 Ammodytes, samt et Par Annelider.

1 De ovennævnte 2 Crustaceer udgjore, som bekjendt, ligeledes Hovednæringen for enkelte af de storre Hvalarter, som om Sommeren soge ind under Finmarkens Kyster, og betinge saaledes til on vis Grad ogsaa Fangsten af disse Dyr hos os.

Dette er saaledes Tilfieldet med Blaahvalen og Seihvalen, hos hvilke Arter udelukkende denne Fode er fundet $\mathrm{i}$ den Tid af Sommeren, hvori disse Hvaler besøge vore Kyster. I 1855, da Seihvalen (Balaenoptera borealis) i hidtil ukjendte Mrengder stodte under Land udenfor Finmarken, vare Ventriklerne hos alle de Individer, som jeg havde Leilighed til at undersoge paa Fangststederne, fyldte alene med Calamus fimmarchicus. (Proc. Zool. Soc. Lond. 1886, p. 261.)

Blaahvalen (Balaenoptera musculus) synes fornemmelig at vare afhængig af den anden af de nævnte Crustaceers Optræeden, nemlig Boreophausia inermis. 
IIn en |r| Individer, tagne paa Line i Porsangerfjord 12te Juli 1896, fandt jeg følgende Fiske:

Hairosue Expl. af Mullotus tillowus ${ }^{1}$ : Ingel af Cottus scorpin: an C'yclopterus lumpus (omtr. 10mm lange); Unger af limbe-irter, og af Hipponlossoid. platessoides; desuden Unger af Lumpenus lampetriformis, og af en Ammodytes.

Lings Landets Vestkyst foregaar ligeledes hele Sommeren et mer eller mindre rigeligh Seifiske, hvilket her hovedsagelig er betinget af Smaasildens Tilstedeværelse. I storre Exemplarer er fundet indtil 20) saadanne Smaasild (af 5-6 Tommers Langde, eller mere).

Om Vinteren, naar de næunte Plancton-Crustaceer i de umrdlige Landsdele mangle, tager Seien her vesentlig Fiske og Cephalopoder, samt enkelte Crustaceer. De store Indsig af Sei, som finder Sted ved de finmarkske Kyster i de forste VaarManneder (April Mai), ere saaledes i vasentlig Grad betingede (ligesom for Torskens Vedkommende) af Loddens Vandringer fra Ishavet mod Land for at gyde. Naar Sei-Stimerne her komme under Land, hefinde de sig i en afmagret Tilstand, men opnaa hurtigt sit Huld efterat have fraadset en Tid i den overflodige Næring af Lodde.

Af Blaksprut tager den fornemmelig de mindre Exemplarer af Ommatostrephes todarus.

I le sydligere Districter soger ligeledes Seien under Land i Vintrmatnederne, idet den her forfolger Vaarilden og denYingel. Iovright lever Seien paa denne Aarstid her af diverse trustweer, saasom af Capreller, samt i stor Udstrakning af Vigntiphrues norregicus, leilighedsvis ogsaa af forskjellige Slags: Fïlir inili-1)m af Clupea sprattus). Blandt de storre (irustaceer har Ip. Nublatard ved Dergen fundet Ventriklerne indeholde Portume holsatus.

1 I Porsangerfjorden kaldes dette Stadium Vas-Lodde. 
Gadus aeglefinus, Lin. 1766.

Forplantning. Gydetiden indtræffer hos os $\mathrm{i}$ de forste Vaarmaanerler, i Regelen i Mart.-April, men undertiden lidligere; saaledes opgives fria Vardu, at los Rogn ofte trafles allerede $\mathrm{i}$ Januar.

Paa Bankerne udenfor Christiansumbl angives Hysen regulært at have los Rogn omkring 12te Marts.

I April og Mai er Individerne oftest udgydte; men leilig. hedsvis findes endnu i Mai el eller anded, hris Rogn endun er fast.

Den gyder saavel i den ydre Skjærgaard, som ogsaa i de storre Fjorde: den erholdes herunder paa 30-40 Favne Vaml (i) (1) - T) Meter). men staar oftest dybere (indtil omkring zoo Meter).

Et middelstort Ind. (Totall. sis $0^{\mathrm{mm}}$ ). fanged ved Rudn i Ilelgeland sde April (1909). og nedsendt til Christania-Musert, havdr. los Rogn (der dog endun syotes i sin Helhed at vare tilstede). Ilos detle Ind. var Ovariets santlede Vogt :39:31 : Ciram; med

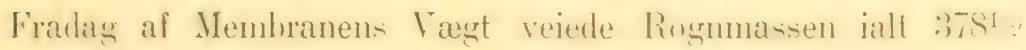
Gram. Tha hert Gram talte omtrenl zenon Rogn, war det hele. Antal saaledes omtr. 832,700 St. $^{1}$

Gidetilen synes at indtraffer nogenlunde simtidigt i Landel. nordligste og i de sydligste Egne.

I Christianiafjorden har jeg fundet lingel med en 'Totall. af

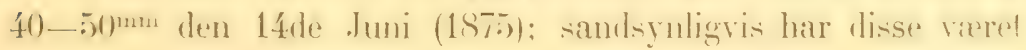
udklækkede omkring Begyndelsen af Marts.

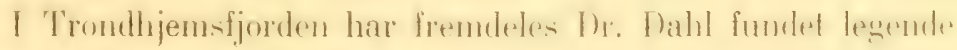
Fiske fra Februar til Udgangen af April.

Yngel. Gydningen kan foregaa lige inde $\mathrm{i}$ Bunden af de

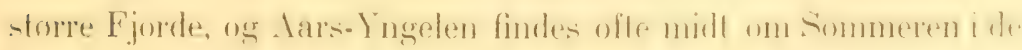

1 Dette Antal stemmer godt overens med Fultons Trellinger af Rognen hos et omtrent ligestort Ind. fra Kiysten af Scotland. Hos hans Ind., hvis 'Totall. var' $569 \mathrm{~mm}$, var Antallet 806,459 St. (cfr. Hoek, Cons. Perm. Intern. Expl. de la Mer, Public. de Circonst. No.3, p. 36, Khhon. 1903). 
wree Vandlas inde mellem Veme udenfor Christiania sammen

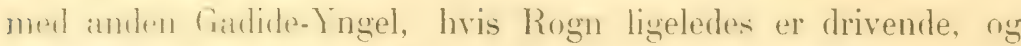
uden at de paa denne Tid kunne antages at være forte ind i Fjordbunden med indgaaende Stromme,

I Bumlen af Laxefjord (Fimmaken) har jeg ligeledes fundet lingel-Individer af Cr. aeglefinus med en Totall. af $37^{\mathrm{mm}}$ (1m Sommeren (13de Juli 1880).

I surre Antal nptrader Lingelen vistuok i Fjordmundingerne "ي i den ydre Skjergard, og Dr. K. Dahl har i Juli Maaned

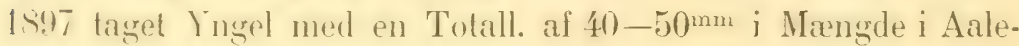
vad paa grundt Vand ved Jæderen.

lingelen lorer, som andre Garlus-Arter, idethele et pelagisk Liv i de ovre Vandlag. Ligesom G. morrhua soger den hermnder ofte 'Tilflugh muder drivende Gjenstande, saasom Tang, og fraffes sialedes undertiden under Cyamea cajpillata: allerede i crexti-Aareme indsimmlede l'rof. Sars Linger under Cyaner i Vestfjorten med an Tolall. mellem $33^{\text {mon }}$ og $66^{\mathrm{mm}}$. Som ovenfor narnt, indkinmlede jeg 14 de Juni 1875 mellem Oerne udenfor Christiania talrige Lnger med en Totall. af mellem $32 \mathrm{~mm}^{\mathrm{m}}$ og 5.) mun. hrilke liseledes for en stor Del havde sit Tilhold under Cyanea; hvor disse med Makrelgarnene bleve dragne tillands, fulghe arlskillige L'nger med, der ikke ilide havde smutted væk mellem Maskerne.

Fode. ri. conglefinus, der har sit Hovedtilholdssted paa blod Ler- allex Mudderbund, soger sin Fode for den wrerveiende Del blandt Bunddyr.

Hor lngel har jeg fundet Fulen bestanende af pelagiske l'landun-finstawer. Ios et Ind. med en 'T'otall. af $66^{\mathrm{mm}}$. laget

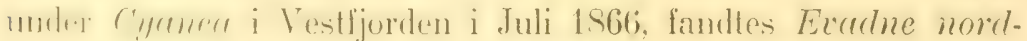

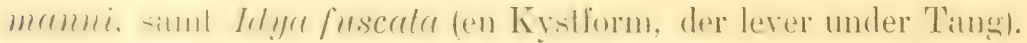

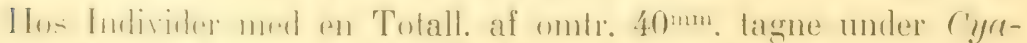

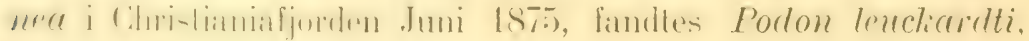
samt Temora longicornis, den sidstnævnte talrigt.

De aldre Individers Fode er yderst vexlende, og bestaar saa at sige at alt levende i Havet, som kan sluges. Er Sild 
eller Lodde tilstede, bestaar Foden udelukkende af disse; desuden tages andre mindre Fiske og deres X Yngel. Som dens mesl normale Fode kan muligens ansees Grustaceer og Mollusker;

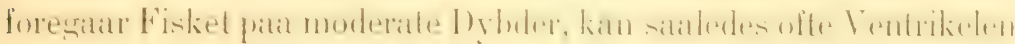

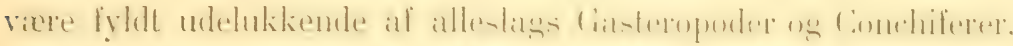

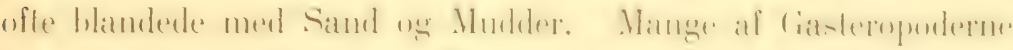

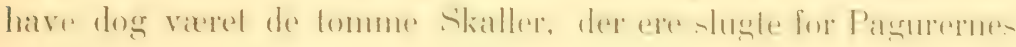
Skyld; men i Regelen ere Molluskerne friske.

Iøvrigt er Foden vexlende efter Aarstiden og Opholdsstedet. Dr. Olsson, som i Sexti-Aarene undersogte denne Arts Fode ved

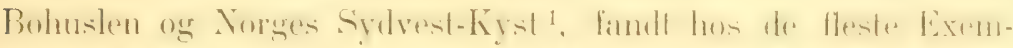

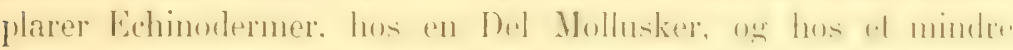

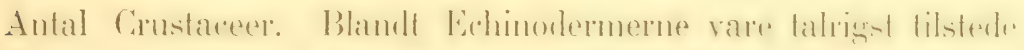
Ophiurider, hlandt Molluskerne smata Comehiferer. Desulen formefandtes undertiden Annulater; med Føden var ogsaa her særdeles hyppigt slugt en Del lerblandet Grus.

Ogsaa Dr. Nordgaard ${ }^{2}$ har ved sine Undersøgelser ved Sun-

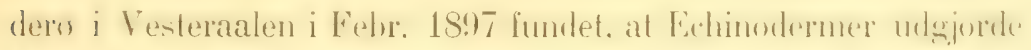

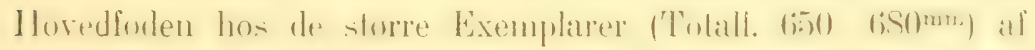
deme Art. Ear fandtes Ophiurer og Edhinder (Ophiopholis,

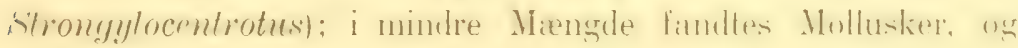
sjeldnere Annelider (Leodice).

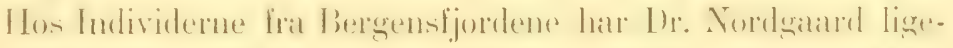

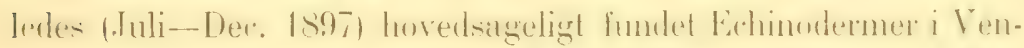

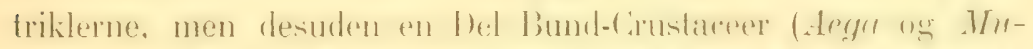

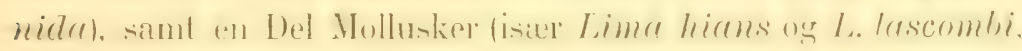
samt Cardium fasciatum).

Hos en Del Ind. af Middelstorrelse, fangede i Trondhjems-

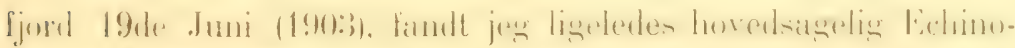

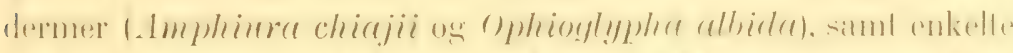

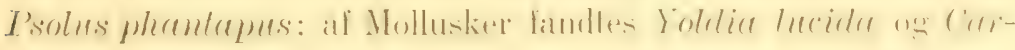
dium parvum.

Acta Univ. Lundens. 1871. III, p. 61. (Lund 1871-72.)

- Bergens Museum. Rep. Norw. Mar. Invest. 1895-97; Contrib. Study Hydrogr. Biol. Coast of Norway, p. 17. (Bergen 1898.) 
El l'ar yngere Individer fra Christimiafjorden (5te ()ct. 191:3) indeholdt undulikiende Mollusker, nemlig et stort Antal Phitine aperta, sumt enkelte Ph. scabra og Unger af Mytilus.

L.1 haracteristisk Bidrag til vor Kundskah on denne Arts Fonde wal Lambets nordligste Kyster a givet fra Vardo i 159:3 at hr. Sparre Schmeder. Ved Conserv-Fahriken i denne By, hvor det viesentligste Rati-Materiale hestan af denne Art. har Stud. E. Dithl gjennem en Rieklie af Aar giont en Indsanling af MLolhusker, som kunde findes hos de til Fabriken indforte Hyser:

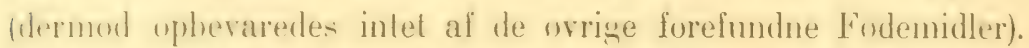
Det hete Mollusk-Maleriale blev oversendt til Tromsu Museum, "n $\mathrm{i}$ (nn speriel Ahandling ${ }^{1}$ har Dr. Sparre Schneider givet en Oversigt over de forefundne Arter.

Det viste sig, at Samlingen bestod af flere Tusinde kxemplarer, vasentlig Casteropoder, for en mindre Del Conchiferer log Terehratuliner), ialt tilhorende 92 Arler. Af enkelte Arter fandtes Here Hundrede Exemplarer; af saadanne kumne nevnes Trochus occidentalis, Iatica clansa, Trichotropis borealis, Scalaria aroenlundica, Admete viridula. Spirotropis carinata. Trophon clathratus, Bela pygramidalis, og Margarila groenlandica. Af den sidstnavnle fandten isier store Masser, og enkelte Ventrikler havde været helt fyldte af denne Art.

benden fandtes i hundrederis Haldheimia cramimm, men langt sparsommere de ovrige Terebratuliner.

Af -jeldnere Arter indeholdt Samlingen Exemplarer af Poromy!n gramulatu, Ampullina smithii, Laeocochtis granosa, Sipho jusiformis, "ser Scalaria obtusicostatr. Al den sidstnatvole Art

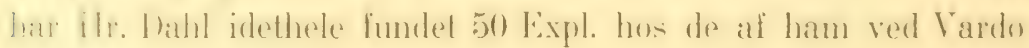
undersngte Hyser.

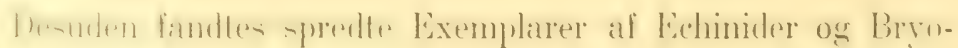
zoer.

"Nogle Bemarkninger on Hysens (G. aeglefinus) Nieringsforholde". 'Tromso Huseums Aarshefter, B. 16, p. 1. (Tromso 1894.) 
Flere af de forefundne Gasteropoder havde sandsynligvis

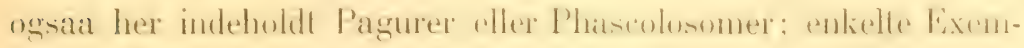

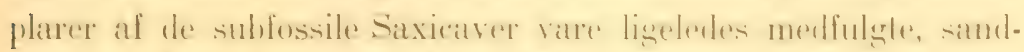
synligvis fordi de havde algivel stotle for audre liundelyr, silatsom Annelide-Ror, eller Terebratuliner.

Storrelse. I overordentlig store Masser optræder Hysen i Finmarksfjordene, og erholdes her Aaret rundt (mindst om

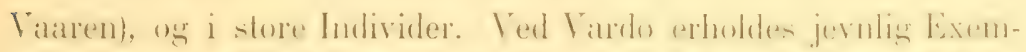

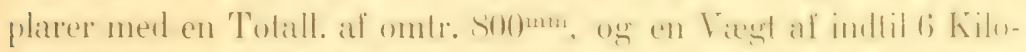

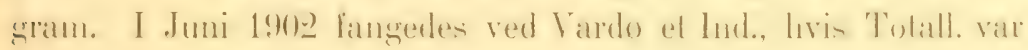
$1100^{\mathrm{mm}}$.

Ved Landets sydlige Kyster synes den ikke at opnaa en

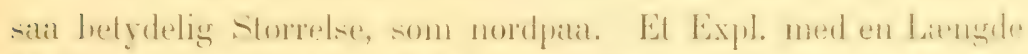

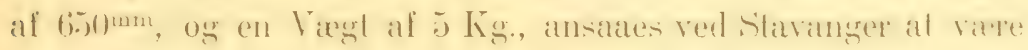
ualmindeligt.

Gadus pollachius, Lin. 1766.

Forplantning. Indtræffer, ligesom hos andre Gadus-Arter, i Vaarmaanederne. I Marts og April har Dr. Dahl1 i Trond-

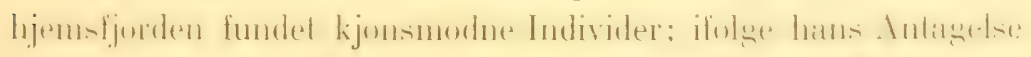
(1898) synes Aars-Yngelen helt at mangle i denne F jord, men han har fundet den $\mathrm{i}$ September i den ydre Skjærgaard (ved

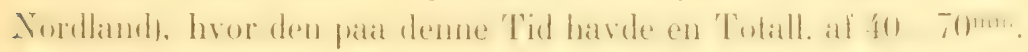

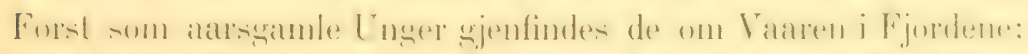

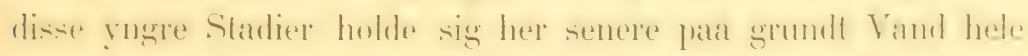
sommeren igjennem, og torvfures liside om Ilustent i alle Byer sammen med de yngre Stadier af andre Gadus-Arter. I Christianialjorden have disse Unger i August og September en Lœngde af $120-200^{\mathrm{mm}}$ (eller derover).

De Iagttagelser, anganende Yngelens Udvikling, som jeg

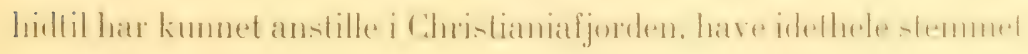
overens med de ovenfor anforte fra Trondhjemsfjorden.

I Kg!. N. Vid. Selsk. Skr. 1898, No. 10, p. 39. (Thjem. 1S99.) 
Blimbl den Lalrige Masse Yngel og Unger af Aarets Kuld, som jes i Aarnes Loh har indsamlet af Fadder $\mathrm{i}$ denne Fjord, har iklir lorelimmmet en eneste C. pollachins. Hvorvidt detle har havt sin Fround i, at Arten i Virkeligherden helt har manglet her i dette Stadium, kan endnu ikke oplyses.

Eggene er yderst fine og talrige. Hos et Exemplar af Middel-torrelse ('Totall. 550 $0^{\mathrm{mm}}$ ), fanget ved Melo i Nordland 2den Nai (1!):3). fandt jegr Rognmengden at udgjore omtr. 2,650),000 St.

I Stramdsoer. Saavel deme Arl, som enkelte andre GadusArter (sant Chneen harengus), trænge red Landets Vestkyst ikkr jedten ind i mindre Ferskrande, der ved Hoivande staa $i$ Forbindelse med Snen, og de kunne leve og trives her, endog livor denne Forbindelse med Soen tilsvneladende er afbrudt. og hror Vandet ialfald paa Overfladen er luldkommen ferskt.

lit l'ar sadanne Indsoer i Nordre Bergenhus Ant omtales allerede al Dar i 1854. En af disse er Indrehnsvandet i Mirlsulen (Bremanger). Ved en temmelig rivende Elv, hvis Liengde (2) ontr, 5)(0) Heter, er denne Indso forbundet med Suen; den ernares af Issvandet fra de omliggrende Fjelde, og er under al. mindelig Vandstand helt udelukket fra Søen.

I denne Indso er G. pollachius talrig, men naar ingen betydelig Størrelse.

I Brenangerpollen findes ligeledes et V'and, Dalevandet, der sam i Forbindelse med Soen ved en omtr. 300 Meter lang graved Kintal, og som blot under Hoivande modtager Saltvand fira llavet. I defte Vand findes ligeledes formden Salmo erior)

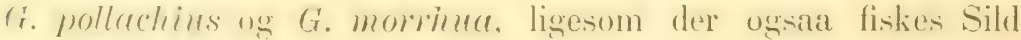
med Not. Torsken i dette Vand er slet, og ansees for neppe spiselig.

En ligmende: Strandso findes i Bunden af Sureidford pai

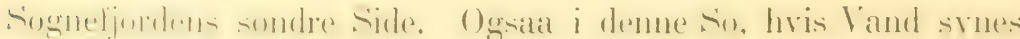
at være ganske ferskt, findes G. pollachius, $G$. virens og $G$.

1 Day, Fishes Great Brit. and Ireland, Vol. I, p. 271. (Lond. 1850-84.) Senere bekreftet og supplerel al Lensmand Haaland (Brev af Jan. $1903)$. 
mor\%ma. og enkelte af de forsmiernte. Arter kunne fiskes rndu: i den Strom, som fylder Soen med Isvand fra de omliggende Bræeеr.

Afstanden fra Fjorden er her kortere, omtr. 60 Meter, men Elven er ogsaa her temmelig striblubmoles skont strommen slandses ved Hoivande.

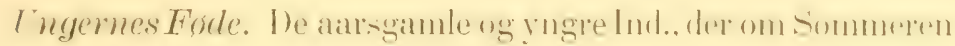
og Hosten ere talrige i Fjordene, ernære sig dels al Plancton.

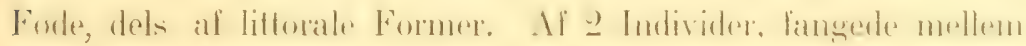

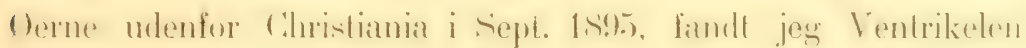

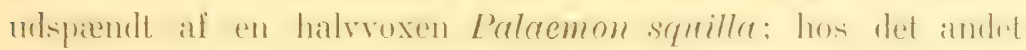
indeholut den en Fisk. sandsynligvis an fiobins. Ios yngete

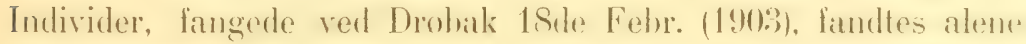

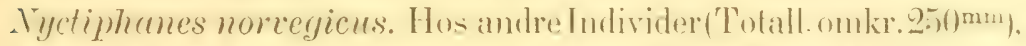
fangerle i Christianiafjorden am Hosten (:30te Sept. 190:3). rame ligeledes Ventriklerne fyldte nesten alenes af Nyclimhanes: los enkelte fandtes desuden wn an anden Fiske-linge (hvoral kunde kjendes Gobier).

Et Ind. fra Trondhjemsfjorden (Totall: $170^{\mathrm{mm}}$ ), fanget i Juli 1S98, var fuldproppet af Calames fimavehicus.

Gadus minutus, Lin. 1766.

Nordgrcendse. Denne Art forekommer spredt langs hele Norges Kyst indtil ovenfor Polarcirkelen.

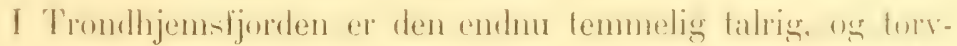

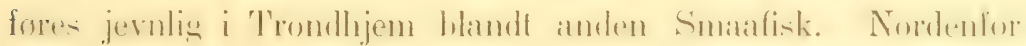

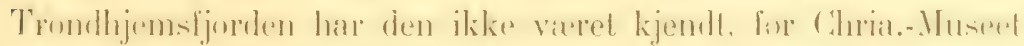
modtog et udvoxet Expl., fanget ved Ravik i Yttre Salten Sde Mai 1900.

Storrelse. Stavanger Mus. har et Expl. (udstoppet), der har en 'Totall. af 285 $\mathrm{mm}$; heraf har Hovedet en Langde af $60 \mathrm{~mm}$. (Stavangerfjord 30te April 1884). 
Noget mindre Individer har jeg flere Gange fundet paa Fisketorvet i christiania; et Int. med en Totall. af $250 \mathrm{~mm}$, fanget ved Langesund 28de Febr. 1903, var en rognfyldt Hun.

Forplanlning. Ved Landets sydlige Dele indtreffer Gydeliden i Marts og April. Enduu i den sidste Halvdel af Marts træffes Individer, hvis Rogn er fast.

Forde. Hos Individer, langede i Hostmanederne mellem (Gerne udenfor Christiania. er Ventrikelen i Regelen fyldt med sma Fiske (Gohier), og blandt disse er især hyppig Aphya mimete. Allerede hos en Unge med en Totall. af $87^{\mathrm{mm}}$ har jeg fundet et Expl. af den nævnte Art, hvis Totall. var $33^{\mathrm{mm}}$.

Et Inrl., optaget ved Ferkingstadoerne (udenfor Stavanger) lide August 1898, indeholdt Dele af en IIipuolyte. Et andet Inst-Ind. fra Trondhjemsfjorden (7de August 1885) var fyldt med mindre Bund-Crustaceer (Lemon nasicus, og Metridia lucens), samt med Borster af Annelider, satedes Former, hentede paa eller ved Bunden.

Hos Inger med en Totall. af omkr. 100"mm, fangede udenfor Christiania 1sile Sept. (1903), fandtes nesten udelukkende Crustaceer, fornemlig Mysis inermis i stort Antal, samıt smaa Amphipoder (Commarus locusta og Aphernsa bispinosa), nogle Crangon, samt Unger af Mytilus.

lit Vinter-Ind. fra Christianialjorden ISde Jan. 1901) var fuldproppet af en Thysanopode (Nyctiphanes norergicus).

\section{Gadus merlangus, Lin. 1766.}

Udbredelse. Gaar mod Nord til den russiske Grændse, men -ynes at virer forholdsvis sparsom ostenfor Nordeap. Den foreknmmer imbillertid molnu i Varangerfjorten; et Ex., fanget

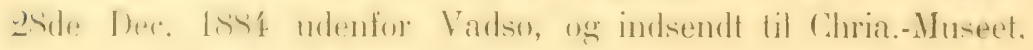
havde en 'Totall. af $305^{\mathrm{mm}}$.

Storrelse. Det største Ind, som jeg i de senere Aar har

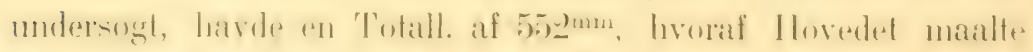
$136^{\mathrm{mm}}$ (Christianiafjord 25de Aug. 1887). 
Forplantning. Et Ind. (med endnu fast Ovarium), fanget udenfor Christiania 32 de April 190:3, (Totall. 345 $55^{\mathrm{mm}}$ ), havile of Rogn-Antal af omtr. 285,000 St.

Misdannet Ind. Et Ind. med lodret Pande (en Form, der ikke er sjelden hos G. morrima,) modtog Chria. Museet fra Derne udenfor Christiania 9de Juni 1897.

Ungernes Fode. Hos Unger med en 'Totall. af omkr.

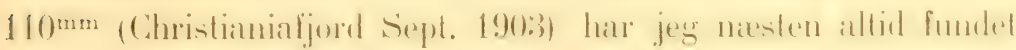

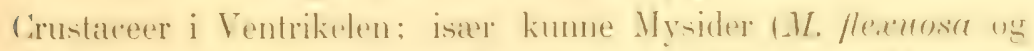
II. incrmist undertiden helt fide denne. Ofte linden Unger at forskjellige Amphipoder (Gammanus og Hyperia).

Gadus esmarkii, Nilss. 1855.

Udbredelse. Denne Art er udbredt paa mange Localiteter ved Landets srdlige og restlige Kyster op til Tromdlijemstjorden men er muligens i sin Optræden noget local.

I Christianiafjorden, hvor den kaldes Øienpaal, er den

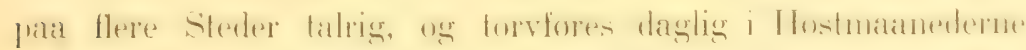
i Christiania; den fanges paa Dynd- eller Lerbund mellem

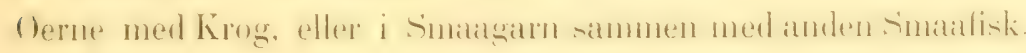

I de senere Aar har den vist sig at være talrig ogsaa $i$

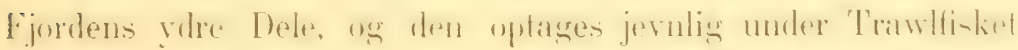

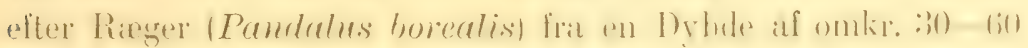

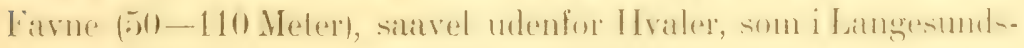
fjorden, (hvor den gaar helt op i Frierfjord til Porsgrund).

I Sept. 1901 fandtes den af Dr. Hjort (med „Michael Sars")

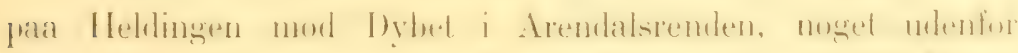

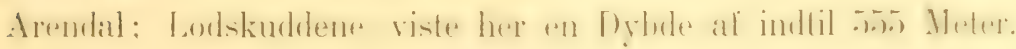

Det er sandsynligt, at den efterhaanden ogsaa vil paavises ved andre Puncter af Landets Sydvestkyst. Som tidligere nævnt, eier Chria.-Museet et Expl., samlet af Prof. M. Sars i Femti-Aarene udenfor Florø (Nordfjord). 
Eudrlig or den ikke sjelden i Trundhjensfjorden, hvor den

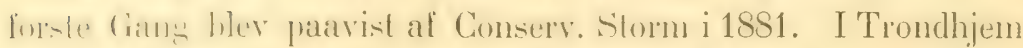
hate jes flere Giange indsanlet torvforte Exemplarer, og den mholder her jernlig paa Heldingen ud mod de store Dyh i Sommermanederne. Den kaldes her Lysing.

Forplanmine. Groder i Christianiafjorden i Februar ag Marti. Hunner (med en Totall. af omtr. 215, man) have de fleste af Rognene rindende $\mathrm{i}$ Slutningen af Februar.

Et Individ. optaget i Trondhjensfjorden 24te Februar 1s S4, (Totall. 1!1 $\left.{ }^{m m}\right)$, havde netop Ovariet udspendt af fuldt moden

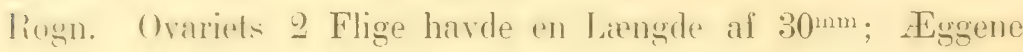
vare yderst smaa, alle jevnstore, og havde en Diameter af imtr. $01, \cdot)^{m+m}$

E) Par Ex.. fangede ved Steilene (udenfor Christiania) Lode Mart (1!):3), havde gydelordig Rogn, hris Antal hos hegge viste sig at være omkring $70,000 \mathrm{St}$.

Smat Unger (med en Totall. at $333^{\mathrm{mm}}-75^{\mathrm{mm}}$ ) har jeg af og til truffet on Ibsten (Sept. til Nonember) blandt de til Christiania lorvforte smanfisk. men paa Grund af de forholdsvis stormaskede? Garn blive disse kun sjeldent fangede.

Føde. Hos halvvoxne og udvoxede Individer, fangede i Christianialjordens indre Dele i Hostmananederne, har jeg ofte fundet Ventrikelen fyldt af Aphya minutu, an Art, der om Inoten alsiver Forde for en Flerhed af de smaatiske, der heho moderate Dybder paa denne Localitet.

Hos de smaa Unger om Hosten er ofte Ventrikelen fyldt al Copromerer (Tulestris) eller Mysider. og selv noget storre

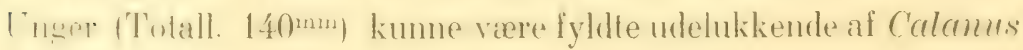
helgolandicus.

Gadus poutassou, Risso 1826.

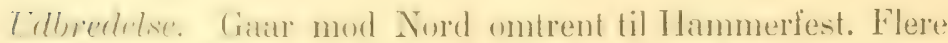
Individer w. ustat $\mathrm{i}$ de senere Aar fundne i Oxfjord og ved Hasvig paa Søroen. 
Storrelse. Det storste Ind., som jeg har undersogt fra Norge, havde en 'T'otall. af $460 \mathrm{~mm}, o g$ var fanget blandt andre 'l'orskearter paa ringe Dybde mellem Derne udenlor Christiania 24de Oct. 1896.

Fode. Hos unge Individer fra Oxfjord (V. Finmarken) har jeg fundet fVentrikelen fyldt af Eoreophousin enermis. Ilos

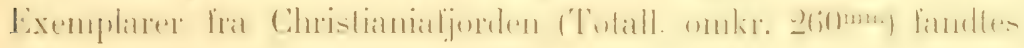
Pasiphä̈ tarda (2den Oct. 1903).

Gadus argenteus, (Guich.) 18500.

Ny for Fannaen 1897. Denne Art blev forste Gang paa-

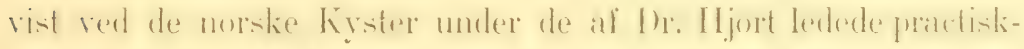

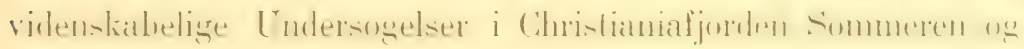
Hosten 1897.

Det viste sig snart, at den paa det noget dybere Vand paa Lerbund forekom i ikke ringe Antal, og i de nærmest paafolgende Aar blev den gjenfundet saavel paa nye Localiteter i

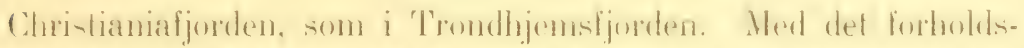
vis hetydelige Materiale af denne Alt, som afterhatanden stod til

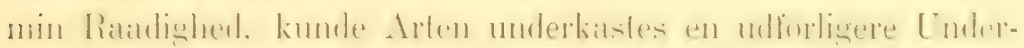

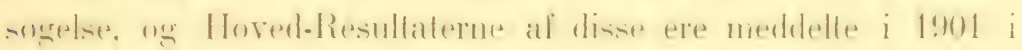

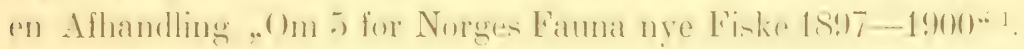

Af disse Meddelelser gjengives nedenfor det væsentlige af dem, der vedrøre Artens Storrelse, Forplantning, Fode, og Udhreedelse hos os. samt de nyere lagttagelser. der foredigger frat de sidst forlobne Aar.

Storrelse. De fleste ved Norges Kyster erholdte Individer

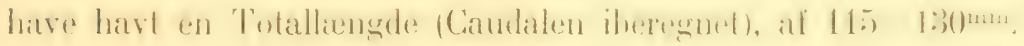

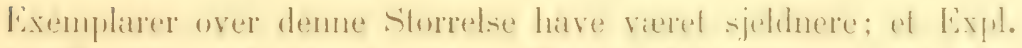

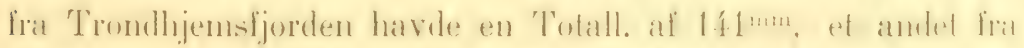

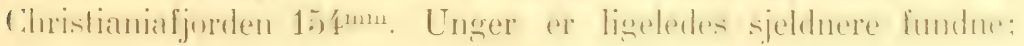
de mindste hidtil undersogte vare fra $71-78^{\mathrm{mm}}$ lange.

1 Archiv Math. Naturv. B. 23, No. 7, p. 5 (Chria. 1891). 
Forplantning. Hunnerne syntes at være talrigere, end Hannerne. on saagodtsom alle storre Individer vare Hunner. . If 12 Individer, optagne mellem (lerne ovenfor Drobak 7de-9de Sept. 1\$? V. vare saaledes 2 Hanner, \& Hunner, samt 2 Unger.

Yngletiden strækker sig over flere af Høst- og VinterMannederne. Allerede $\mathrm{i}$ Begyndelsen af September vare flere Humner rognfyldte. om end Eggene hos de fleste vare ujevne $i$ Sturrelse; et lixpl. syntes dog allerede at vere udgydl (Drohaksund Sept. 1897).

Individer, optagne i 1898 i Slutningen af September i Laurvigsforil, vare ligeledes rognfyldte, tildels tilsyneladende sydefardige: men hos et stort Hun-Individ fra Trondhjensfjorden, uptaget i Midten af Januar (1S99), var Rognen fremdeles ikke rindende, men temmelig ujevnt udviklet.

De yogite rognberende Humer havde en Lengde af $110^{\mathrm{mm}}$, de fleste 1200-130mm. De undersogte Hanner hare udviklede Tester ned en Totall. af 115-118mm; en Han med en 'totall. af blot 10.4m havde svulmende Testes Dosde Nor. (1s:9S).

Rognene ere relativt store, omtr. $0,5^{\mathrm{mm}}$ i Diameter. Antallet er forholdsvis ringe, sammenlignet med Antallet hos de ægte Gadus-Arter.

Fode. Ventrikelen, der er aflangt kegleformig, tykragget, og hlansort. har i Regelen indeholdt foruden ukjendelige Lerninger) yiterst fint knuste Dele af Crustaceer (Calanider), samt Borster at Anmelider. Hos et Individ var Ventrikelen udspendt af el Dusin Individer af Euchaeta noreegion. (en Calanide med et forholdsvis haardt Chitinskelet).

Filbredelse. Slijont ar. argentens forekommer i Christiania-

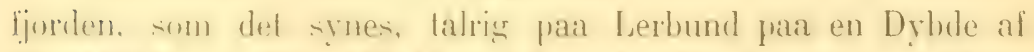
:30-100 Favne (bo-1so Meter) lige fra Fjordens inderste Dele

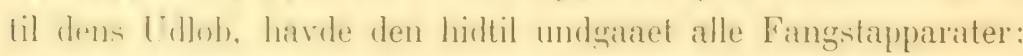
den fanges aldrig $\mathrm{i}$ de ordinere cian, der udsettes for Torsk, Sild eller anden Fisk. og den bider ikke para linog med alminde. lig . Inn: den havele heller aldrig verel at opdage $\mathrm{i}$ de Dyh- 
vandsfiskes Ventrikel, hvorat jeg i Aarenes Lob har kunnet undersoge et ikke ringe Antal.

Den havde idethele kunnet ganske unddrage sig vor Kund.

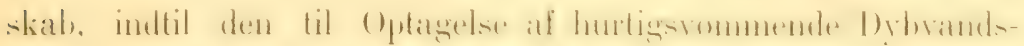

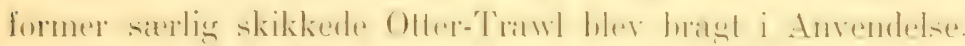

Efterat dette Fangstapparat i Aug. 1897 havde begyndt at virke i Fjordene udentor Drobak, og mellem Oerne nordenfor Drobaksund, erholdtes denne lille 'Torske-Art i næsten hvert

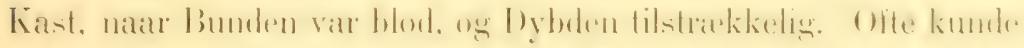

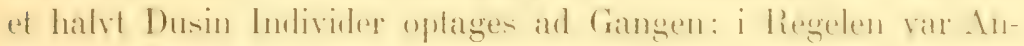
tallet $\operatorname{dog}$ blot 1 eller et Par. Idethele optoges i August og September dette Aar omkring 50 Expl.

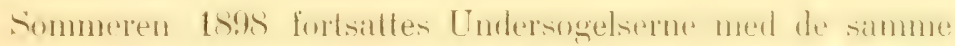

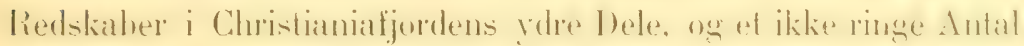

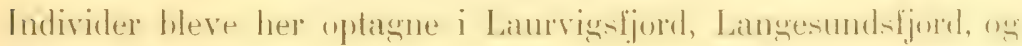
Brevigstjord.

Endelig blev samme Sommer (2Sde Juni 1S9S) et Individ fundet i Tromdhjemsljoteden al Comserv. Storm; "ng moner den al In. Hjort ledede Undersogelse af Fiskeriforholdene i lenme Fündindre Dele i Jan. 1899 optoges atter en Del Individer paa forskjellige Puncter af Fjordens mellemste og indre Dele.

I de seneste Aar er Arten gjenfunden paa saggodtsom alle

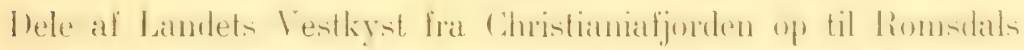

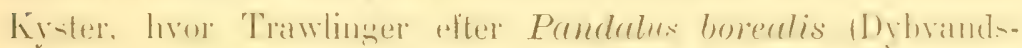
Rægen) have været drevne, og Dr. Wollebæk har herunder kmmet optage lige til omkr. 100 Individer i enkelte 'Trask med Trawlen.

De specielle Localiteter, paa hvilke $G$. angentens hidtil er paavist ved Norges Kyster, ere folgende:

\section{Christianiafjorden.}

Fjorden lige udenfor Christiania (Lysakerfjord og Bundefjord) Sept. 1897.

Mellem Derne nordenfor Drobak (Haagen, etc.) Sept. 1597.

Drobaksund Aug. og Sept. 1897.

Laurvigsfjord Sept. 1898.

Langesundsfjord op til Brevigsfjord Sept.-Dec. 1895. 
2. Vestiysten.

'Talrigr Lomaliteter indentor Bergens Stifts hyster op til Nordmore (Romsdalen) 1901-1902.

3. Trondhijemsfjorden.

Gulosen Juni 1898 og Jan. 1899.

Beitstadfjorden Jan. 1899.

Merlucius merlucius, (Lin.) 1766.

Unger. Smaa Unger af denne Art (med en Totall. af omkr. lonman) optages forholdsvis hyprgt i Rage-Trawlene (under Fang-sen af I'andalus borealis) paa en Dybde af omkr. 50-150) Mrter i lamblets syllige Fjorle. Den deler her ()pholdssted med Ciadus argentens, halvvoxne Gaidropserus cimbrias, og Unger al Mippoglossoid. platessoides. De noget storre L Inger fanges mere leilighedsvis i Gimene on Iusten blandt anden Smatisk i Christianiafjorden.

Storrelse. Det storste Ind. af denne Art, der vides fanget ved Norges Kyster, havde en Totall. af $1350 \mathrm{~mm}$. Dette Ex. vill finget ved Loshingen i Lofoten i Marts 15i3, og indsendtes til Tromso Mus.

Flere Ind. med en Længde af noget over 1 Meter ere erlublte i Chrialianiafjorden og Trondhjemsfjorden. Ved Bergen langedes et Ind. i Jan. 1897, hvis Totall. var $1060 \mathrm{~mm}$.

Nordgrcendse. Som ovenfor nævnt er Arten fundet op til

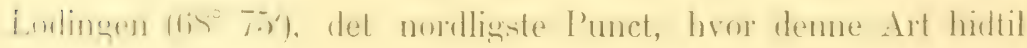
er parvist.

Fode. Hos de smaa Unger med en Totall. af omkr. $100^{\mathrm{mm}}$

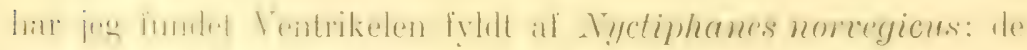

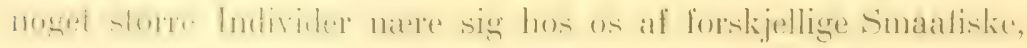
saasom Unger af Sild og forskjellige Gobius-Arter (især $G$. minutus). 
Lota lota, (Lin.) 1766.

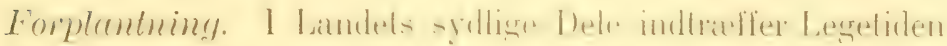
i Februar og Marts. I Mjosen leger den saaledes i Regelen mellem 25de Februar og 25de Mlarts (Huitfeldt-Kaas).

Fode. Smaa Unger', med en Totall. af $32-46^{\mathrm{mm}}$, ere tagne i Maalselven indenfor 'Tromso i Juli 1894. En Del af disse

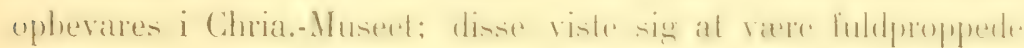

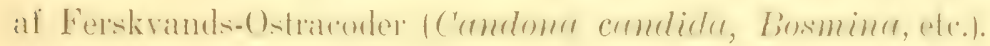

Et yngre Ind. (Totall. $290 \mathrm{~mm}$ ), fanget i Mjosen 27de Oct.

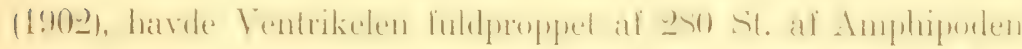

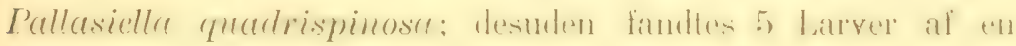
Libellula, og en Larve af en Dytiscide.

Phycis blennioides, (Brümn.) 1768.

Udbredelse. Denne Art viser sig idethele blot sporadisk

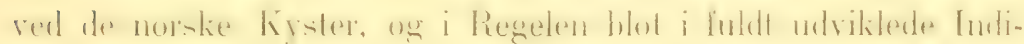
vider, men har været fundet lige op ved Kysterne af 'T'romso Stift. Flere af Individerne have værel fangede paa betydeligt Dyb (180-200 Meter).

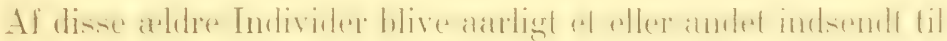

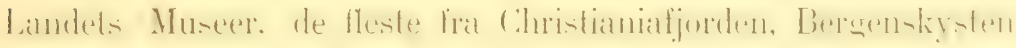
og 'Trondhjemsfjorden.

Smaa Unger vides hidtil ikke iagttagne hos os, men det er dog sandsynligt, at den er stationær og forplanter sig ved vore Kyster.

I de seneste Aar har Chria.-Museet fra Christianiafjorden

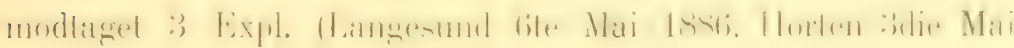
1897, og Skiensfjord 20de Oct. 1897).

Fra Bergenskysten har Bergens Mus. i det samme 'Tidsrum ligeledes modtaget et og andet Individ. Den er her kjendt af Fiskerne under Navn al Skjæl-Brosme.

I Trondhjemsfjorden, hvor tidligere blot et enkelt Ind. var' erholdt (i April 1851), har den senere vist sig at være ikke 


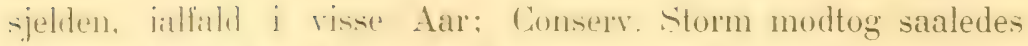
Honten lisyli flere Fxpl. fra Fordens indre Dele, ligesom den hlev langel ved ILaiten ulenfor Fjordens Munding 17de Febr. 1888.

Tordgrandse. Nondenfor Trondhjemstjorten ere blot enkelte Individer kjendte.

I Mai 1SY, erholdt Tromso Mus, ef Expl., langet ved Bjarko (1i! $)^{P}$ N. B.): ug omtrent fra samme Sted (Grotavier) modtog samme Museum et Expl., fanget i Mai 1888.

Endelig. fangedes ver Borholmen i Vesteraalen el Ind. 31te Juli 18SS, hvilket indsendtes til Chria.-Museet.

Stormplse. De storste hos os undersogte Individer have havt "n Totall. af 5.50mm (Christianiafjord Sdie Nai 1897); $555^{\mathrm{mm}}$ ITrondhjemsfjord 17ile Fehr. 1SSS); (i2. mm (Langesund 12te April 18S3); $665^{\mathrm{mm}}$ (Trondhjemsfjord Sde April 1880).

Fode. De fleste af mig undersogte Individer have været uden Fule i Ventrikelen. Ft stort I Iun-Individ fra Halten (udenfor Trondhjemsfjorden) indeholdt Levninger af Fiske.

Molva molva, (Lin.) 1766.

Tilholdssted. Af Fiskerne ansees Langen som en idethele stationater Fisk, der har sit Ilovedtilhold i Kulper i den ydre

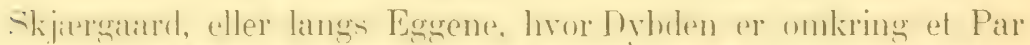
Hundrede Meter. og hvor Bunden hestaar af sandhlandet Ler.

Sum flere andre Gathider foretager den dog utvivbomt liengere "llar kortere l'andringer, skjont disse endnu er lidet kjendte.

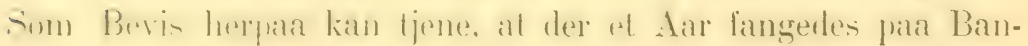

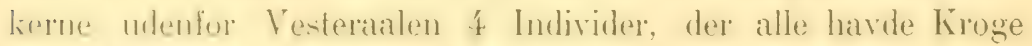

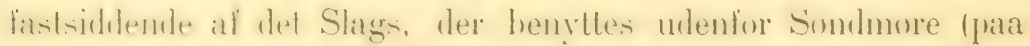
storeggen): hos det ene Individ var endog i Behold det Trixstykke, hvorpaa Skoitens Navn var indbrændt.

1 Meddelt af Væreier Borthen (T'rondhjem). 
1903.] MEDDELELSER OM NORGES FISKE I A ARENE 1884-1901. 5\%

Forplantning. Gydetiden indtræffer i de sidste Vaar- og Sommermaaneder. Paa denne Tid, da den er i sit bedste Huld, foregaar det storste Fiskeri paa Bankerne.

Fra Rodo i Helgeland modtog jeg Ovariet af el stort Ind.,

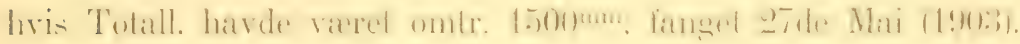
Ovariets Vægt var 2293 Gram (Membranerne veiede heraf S1 Gram). Den venstre Flig havde en Læungde af $440^{\mathrm{mm}}$, den hoire af $330^{\mathrm{mm}}$; deres samlede Bredde var $210^{\mathrm{mm}}$.

Eggenes Antal hos dette Individ var omkr. 12,617,300 St.

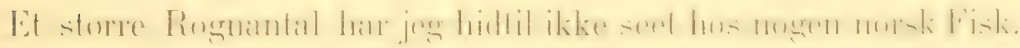

Ungerne kunne leilighedsvis træffes inde i Fjordene, og pan forholdsvis grundt Vand. Dr. Dahl har saaledes fanget flere Unger med Garn paa blot 10-11 Meters Dybrle udenfor Mundingerne af Orkla og Gula i Trondhjemsfjorden i Mai og Juni 1899; disse havde en Lrongde af 170-260mm. Ogsaa i

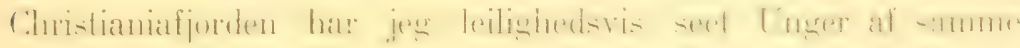

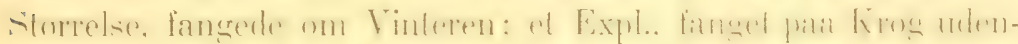
for Larkollen i Dec. 1S91, havde en Totall. af $275^{\mathrm{mm}}$. Det er sandsynligt, at alle disse ere Unger fra foregaaende Aars Gydning.

Fode. Denne bestaar saavel af fritsvommende Former, som af Bunddyr.

De smaa Individer, der fiskes paa de moderate Dybder i Fjordene eller nær Kysten, indeholde ofte udelukkende Bundformer, især Echinodermer og Crustaceer. Hos et Par yongre

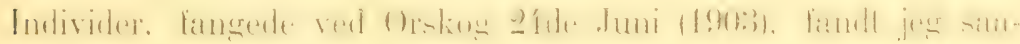

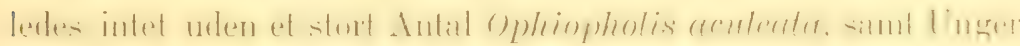
af Strongyloc. droebrachiensis.

Storre Individer, fiskede paa de store Havbanker, synes væsentlig at leve af storre Krebsdyr (Decapoder), og af forskjellige Slags Fiske, (selv Sebastes marimus med sine skarpe Finnestraaler).

I Ventrikelen af Individer, fangede i Febr.-April 1897 ved Sundero (Vesteraalen), og ved Rost i Lofoten, har Dr. 
Nordgatard sailentes fundet Levninger af $G$. neglefinus. Et Indivill. finget i Trondhjemsfjordon 18s0, indehohlt (ifolge Conserv. Storm) et stort Expl. af Chimaera monstrosa.

Sturrelse. Stavanger Museum eier et udstoppet Expl. Ifra Mundingen af Buknfjord ¿tide Juni 1883), der har en Totall. af $1792^{\mathrm{mm}}$ (Hovedets L. $365^{\mathrm{mm}}$ ).

\section{Molva dipterygia, (Penn.) 1784.}

Artsnaun. Pennants Benærnelse af denne Art i hans store Vark "Aretic Zoology". Vol. I. p. LXXVI (London 1784) er grundet paa Müller's L Dagnose i „Prodr. Zool. Danicae“, p. 42. No. 346 (Kbhn. 1776), hvilken lyder saaledes:

346. G. dipterygius, cirratus, maxilla inferiore longiore, pinnis analibus LXX. N. Byrke-Lange, etc.

Det er her at mærke, at Ordet dipterygius utvivlsomt blot tulherer Diagnosen. og ikke er tilsigtet at være et ArtsNarn. Et saadant er aabenbart af Forfatteren (eller under Trykningen udeglemt, hvad der kan sees red Sammenligning med de nærmest foregaaende og efterfølgende Arter ${ }^{1}$.

Skjønt Pennant ikke ledsager Arten med nogen Bestrivelse, hor den af ham anvendte Benawnelse² dog, ifnlge Prioritetens Love, anvender, da den er grundet paa en tidligere, og kjendelig Diagnose ${ }^{3}$.

1 Saaledes lyder Diagnoserne for disse som folger:

313. G. Molva dipterygius cirratus maxilla superiore longiore . . . Lange, etc.

344. G. Lota dipterygius, cirratus, maxillis aqualibus . . . N. Luke, ete.

345. G. Mustela dipterygius cirratus cirris quinque, pinna dorsali priore exoleta.... N. Rodbrune T'ang-Brosme.

377. G. aeglefinus tripterygius cirratus albicans, cauda biloba, maxilla superiore longiore... N. Kollie, Hyse, etc.

2 Cfr. Smitt: Skandinaviens Fiskar, 2dra Uppl., B. I, p. 251 (Stockh. 1892).

3 Af Pennant gjengivet som Dypterygius. 
Tilholdssted. Som en arctisk Art fra det dybere Vand er

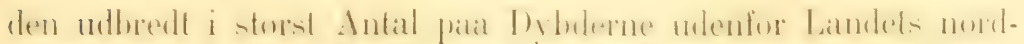
lige Kyster.

Den gaar sjeldnere ind i de dybe Fjorde, og er idethele

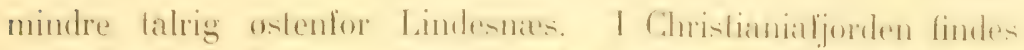

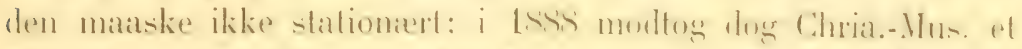

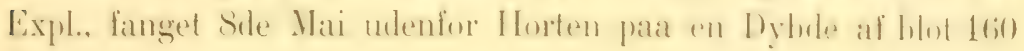
Meter.

De fleste Individer pholdtes faia Dybsign tra en Dohute al

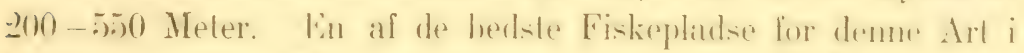
Lamlets norillige Dele er Andena: prial Andrent. Her oplages. atarligh paa Bankerne. i ut Snes Kilometers Afstand fra Land, flere Tusinde Individer: den henternes her alf Fiskerne BlataLange eller Bjerke-Lange, men anseps for mindre rardifuld. end $M$. molva (som her benæunes Norsk Lange).

Unger af denne Art ere hidtil ikke undersogte hos os. Et yngre Ind. i Chria.-Museet (Trondhjemsforden Tde Mart. 1Ssti). hvis Totall. er $498^{\mathrm{mm}}$, er forholdsvis livligt farvet. Oversiden re forstet med hvilightige Marnoreringer i form af korte lya Baand, der noget minde om Tegningerne hos visse Lycoder. En sort Plet findes paa Enden af Dorsalen og Analen, og en stor sort Plet i Enden af hver af Caudalens Flige.

Fode. Da denne Art i Regelen fanges paa udestaaende Redskaber (Line), er Tentrikelen som oftent tom, nam Ludivilerne bringes tillands.

Hos et Par store Individer fra Bergens Fisketorv 27de Juni

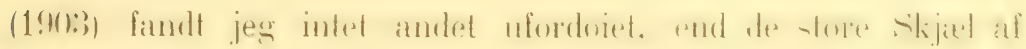
Argentina silus.

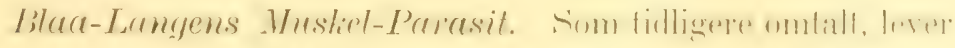

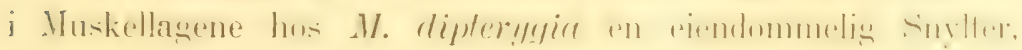
Sarcotaces arcticus ${ }^{1}$, der nærer sig af Fiskens Blod. Dens

Sarcotaces arcticus, Collett. Forh. Seand. Naturf: 11te Monde, Khhrn. 1873, p. 387 (Kbhrn. 1874). 
Levmetshe a i Hoved-agen endmu nasken ukjendt, ligesom den

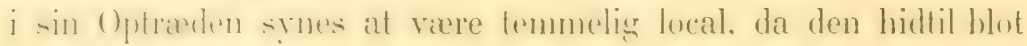
er paavist fra et $\mathrm{Par}$ Localiteter ved Norges nordvestligste Kyster. Ved sit Levesæt og sit eiendommelige Ydre afviger den lra der fleste andre Entozoer, og dens Stilling i Systemet lain endnu neppe siges at vare fuldt oplyst. skjont det red Dr.

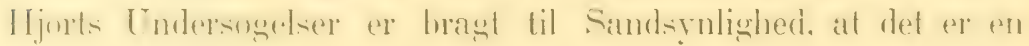
parasitisk Cirriped.

De forste Par Individer af denne Parasit bleve fundne i

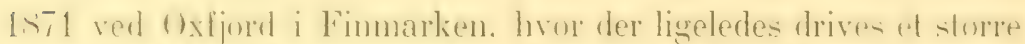

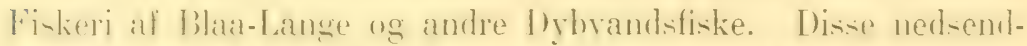

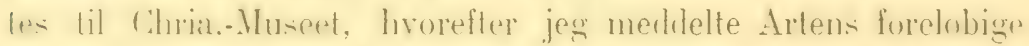
Ibiagnose under Niturforskermodet i Kjobenharn i Juli 1573.

I Aarenes Løb har jeg gjentagne Gange fra den samme Lomilite modtaget enkelte Expmplarer af den simme Snylter,

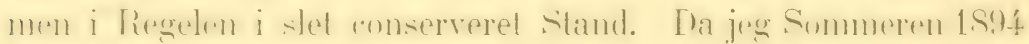

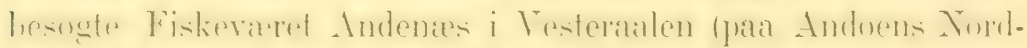

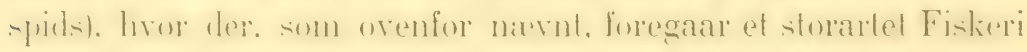

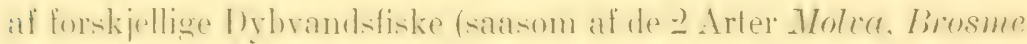

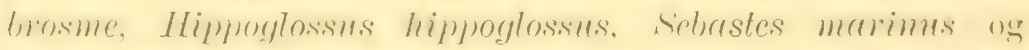
amblee sogte jegr derfor sabvilt muligh at forskafle mig Exemplarer af denne markelige I'arasit. Dette Materiale, horilhand fambles en Del mere eller mindre kjonsmodne Humner, tildek frkble

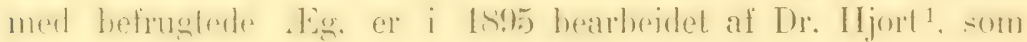

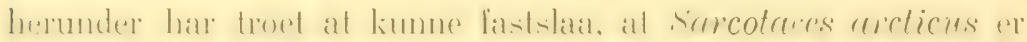
en abnorm, snyltende Cirriped.

Angaaende Artens almindelige Udseende henvises til Dr.

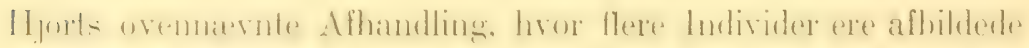

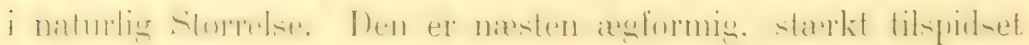
$\mathrm{i}$ den ene Ende, og afrundet $\mathrm{i}$ den anden, og har en ydre Lighed med en colossal Puppe af en Bombycide. Dens Læengde-

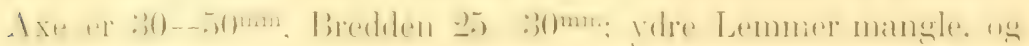

1 Hjort, "Zur Anatomie und Entwickelungsgeschichte einer im Fleisch von Fischen schmarotzenden Crustacie (Surcotuces arcticus, Collett) (Chria. Vidensk. Selsk. Skrifter. 1. Mathem. Naturv. Klasse, 1595, No. 2. Med 2 Pl.) Chria. 1896. 
dens Indre danner en stor Sak, der i Regelen er helt opfyldt af en blakagtig Vadske, det fordoiede Blod.

De Iagttagelser om dens Optræeden, som jeg ved den næevnte Leilighed paa Andenæs havde Anledning til at gjore, vare væsentlig folgende: 1

Blaa-Langens Muskel-Snylter er velkjendt af Fiskerne ved Andenas, og den er her forhadl, da hver Fisk, som skjuler en

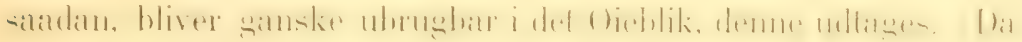
det kun med Vanskelighed kan sees udenfra, om en Lange har Parasiten eller ikke, gjennemskjærer i Regelen Kniven under den hurtige Rensning af Fisken sanvel Snylteren, som den hule Kapsel, hvori den ligger indleiret, hvorved den sorte Vadske flyder ud, og gjor Fiskens Kjod ubrughart.

For at erholde ubeskadigede Exemplarer af Sarcotaces undersogte jeg saamange Blaa-Langer, som jeg kunde overkomme, og i 3 Dage gik omtrent 200 Stykker af disse mellem mine Hander; et lignende Antal bleve undersogte i samme Die-

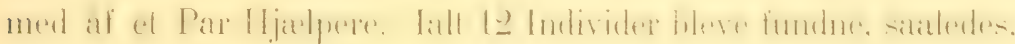
at omtr. 3 pCt. af Fiskene indeholdt denne Snylter. Dette Forhold stemmer ogsaa med Iagttagelserne fra den anden Localitet, hvor denne Art er fundet, i Oxfjord (Vest-Finm.). Her har Kjobmand Buck, som i en Aarrakke arrlig kjobte og lod op-

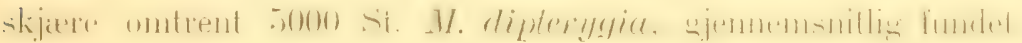
Snylteren hos 3 eller 4 blandt Hundrede Langer; dog har det ogsaa hæendt, at han ikke har fundet den hos flere Hundrede

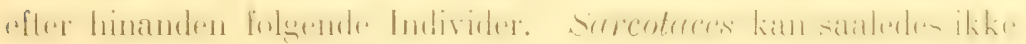
paa disse Steder kaldes nogen saerdeles hyppig Parasit.

De Exemplarer af Blaa-Langen, som indeholde Sarcotaces, kunne ved nogen Øvelse kjendes ved en svag Ophoining i

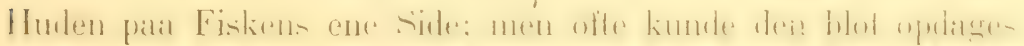

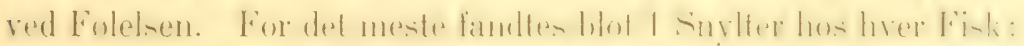

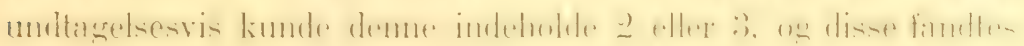
da paa samme Side.

1 De fleste af disse ere refererede i Dr. Hjorts Afhandling "Zur Anatomie", etc. (p. 5-6). 
Snytoren laa leiret i Musklerne paa den Maade, at dens tilspintserte llaleparti vendte ulad, og den afrundecle Side indad. Kun unltugetsesvis kunde sees en Aabning i Fiskens IIud, hrori sulterens yderste spidse stak ud: muligens er denne blot ainhen, indtil Forphantningen er forlo, hvorefter den fine Aabning lukkes. on Drret indkapsles ag dor. Der fandtes nemlig, foruden de friske og levende Individer, adskillige dode og halvt of liste. Wr silkte i Regelen halvt geleagtige, men dog endnu fyldte mend den sorte Vadske: enkelte vare nesten hentorrede, og laa mellem Muskellagene som en aflang, haard Gjenstand. Det synes saaledes, son om Blaa-Langen efterhaanden kan forvinde Sny. terens Ophold hos den.

Blandt de levende Individer vare enkelte blot halvt udvoxede, men invrigt i ingen væsentlig Henseende forskjellige fra de æeldre.

Surcotrces liggrer indleiret i Fisken. Muskler ligesom i en Inle, hris indre Vargge, der bestaa af flere Lag Binderav, ere ganske glatte, og stramt omslutte Snylteren. Naar de friske Muskelhundte. som omgave Kapslen, vare fjernede, blev tilsidst syuligh suylterens atgformige Legeme, som omgaves af en tynd Ind, der udgjorde Hulningens inderste Jag. Hvis Parasiten var levende og frisk. kunde dens Conturer og de vorteformige ('phroininger paa dens Legeme tydelig skjelnes under denne dakkende Membran: var den dod eller halvt oplest, laa den under denne $\mathrm{i}$ en Opløsning af Vand og Blod.

Kun mel den storste Forsigtighed lykkedes det at hefri den levende l'arasit fra det sidste stramme Ifylster. Det mindste Indsnit i T)ret, om hot ef Naalestik, loragte njeblikkelig den

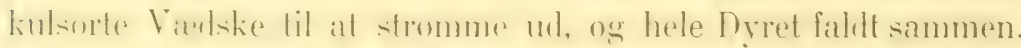

Ilos z af de fumbr. Exemplarer hemerkede jeg under den

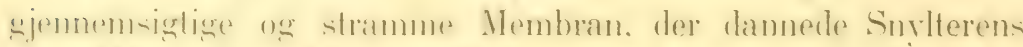

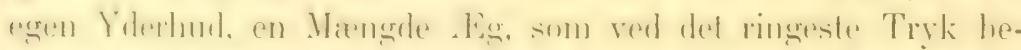

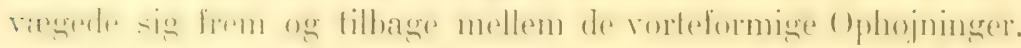

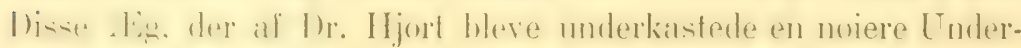
sogelse, befandt sig i 2 Stadier af sin Udvikling.

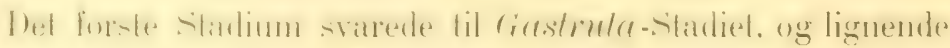

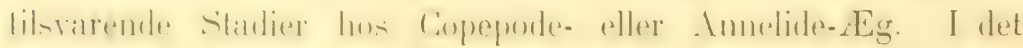




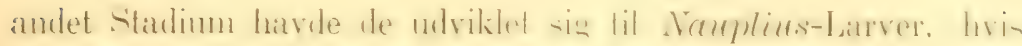

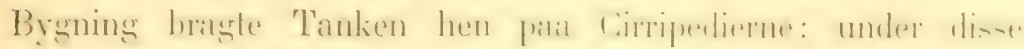

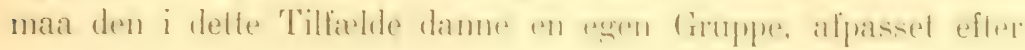
denne Snyllers eiendommelige Levesæt.

Ingelens videre Udvikling er ukjendt. Muligens fæste

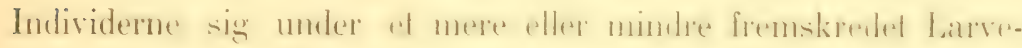

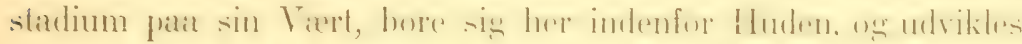
videre mellem Mluskullagenes, ided de med sin eiendenmmelige

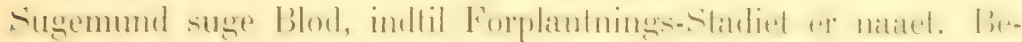

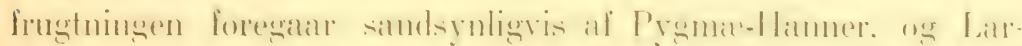

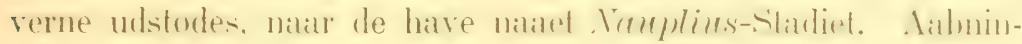
gen i Fiskens Hud gror atter til, hvorefter Individet, som ovenfor nævnt, dor, og hentorres i Kapselen.

Gaidropsarus cimbrius, (Lin.) 1766.

Udbredelse. Denne Art er udbredt langs Landets Kyster fra Christianiaforelens inderste Dele bil Ost-Finmanken. I Cilmi-

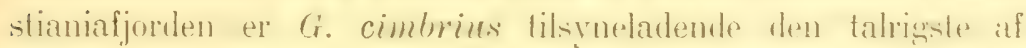
Slægten; i de Skrabbeforsog, som i 1897 og de nærmeste Aar

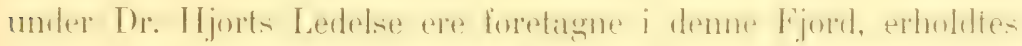
denne Art saagodtsom i hvert Kast med Otter-'Trawlen, saavel yngre, som fuldt udvoxede Individer.

Ligeledes horer den til de Arter, som hyppigt optages

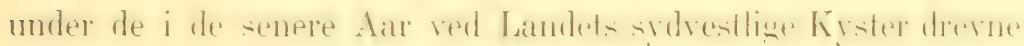

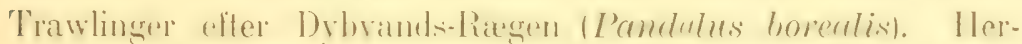

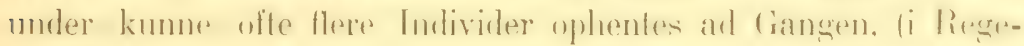
len yngre med en 'Totall. af $100-200 \mathrm{~mm}$ ) fra en Dybde, der varierer mellem 40 og 180 Neter.

Nordgrcendse. Arten er talrig ogsaa i Finmarksfjordene. 'Tromso Museum har nosten aarligt modtaget et eller andet Individ fra Kysterne mellem Lofoten og Nordcap, og under

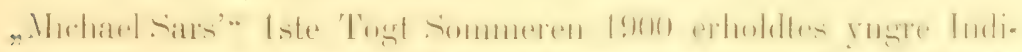

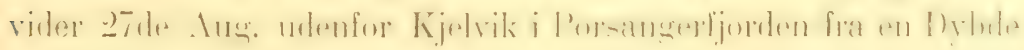
af 150 Favne (270 Neter). 
Forplantning. Hos en Hun med en Totall. af 263mm, op-

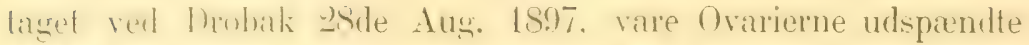
af lown. her dog andun ikke vare helt gydefirdig. Legetiden foregnar sandsynligvis i Vinter-Maanederne.

Storrelse. Den mindste Unge af denne Art, som jeg hidtil

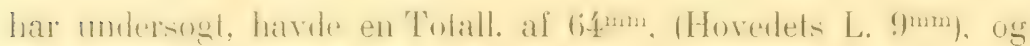

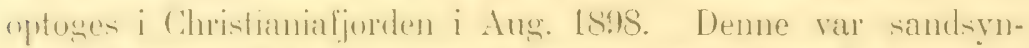

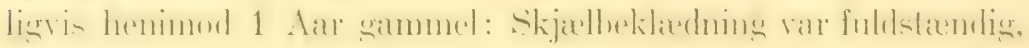
og Farven omtrent som hos de ældre.

Fode. Denne er varieret, og bestaar af forskjellige Invertebrater, samt Fiske.

Flere af de undersøgte Exemplarer have indeholdt udelukkende Pandalus borealis, i hvis Selskab den, som ovenfor

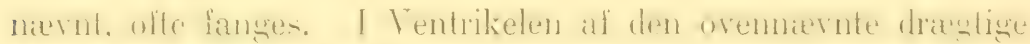

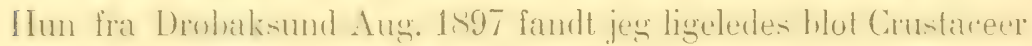

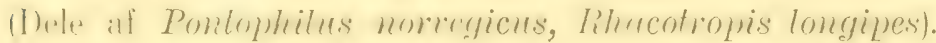

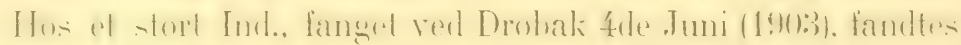
i Ventrikelen flere Expl. af Gobius minutus; hos andre Individer fra samme Dræt fandtes Annelider.

Gaidropsarus mustela, (Lin.) 1766.

Udbredelse. Udbredt langs hele Norges Kyst op til Øx-

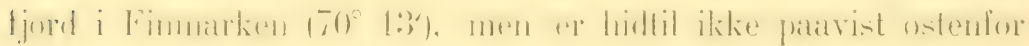
Nordcap.

Skjont Yngelen er optaget paa mange Localiteter rundt Kysten, og tildels i storre Antal, $\mathrm{i}$ de ovre Vandlag, er den ud-

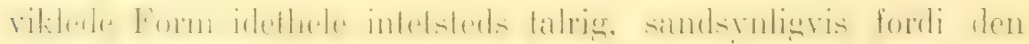

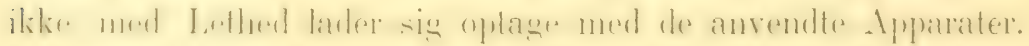

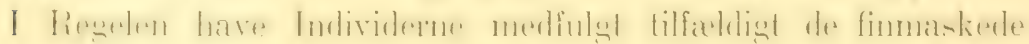

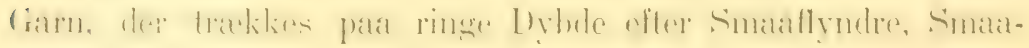
torsk, og anden Smaafisk.

De fleste Individer ere hidtil optagne i Christianiafjorden,

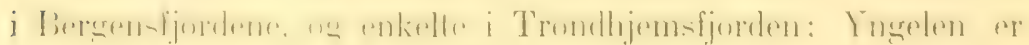




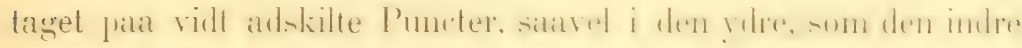
Skjærgaard, hvor det fine Overfladenet har varet anvendt.

Det nordligste kjendte Individ er en spæd Unge, (med en

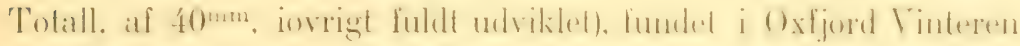
1879-s0 (Chria.-Mus.).

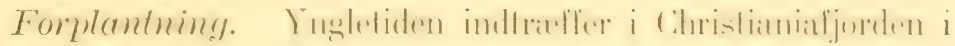

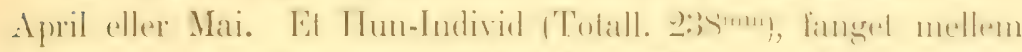

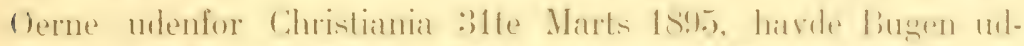

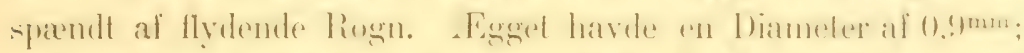

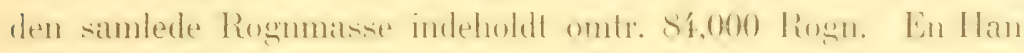

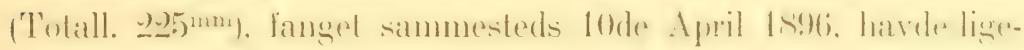
ledes modne 'Testes.

Yngel. Blandt de talrige Individer af denne Slægts Yngel i Larvestadiet, dette hegraendset indtil det Tidspunet, da den solv-

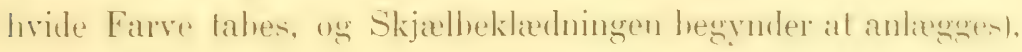
som jeg i Aarenes Lob har indsamlet ved de norske Kyster, kim intethele hol of mindre Antal med sikirtied hestrmmes. ug disse have alle tilhort G. mistela.

Eggene maa antages at være flydende i Vandskorpen

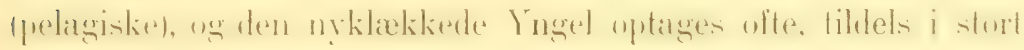
Antal, i de fine Overfladenet sammen med anden Plancton. I Juni 1875 traf jeg mellem Oerne udenfor Christiania en hel Stime af disse spæde Larver, som under Vaddragning bleve trukne mod Land merl Makrelgarnene. Disse havde en Trotall. af $15^{\mathrm{mm}}$; lignende Yngel, der alle maa antages at have tilhort

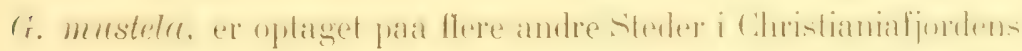
mellemste og ydre Dele, samt paa andre Steder af de sydlige Kyster i Sommermaanederne. I dette Stadium er blot det orre 'Tentakelpar udviklet.

Unger. Det Tidspunct, da Ingelen har afkastet sin eien-

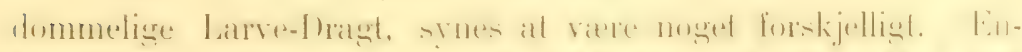

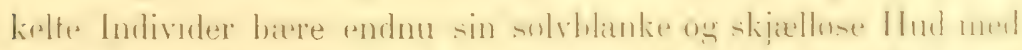

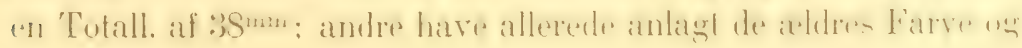


hele L'dreende, nam de ere $35^{\mathrm{mm}}$ lange, og hos disse ere alle 4 Snude-'Tentakler fuldt udviklede.

Gammelt Individ. Den 23de Juni 1897 fandt jeg paa Bergen- Fisketory et endnu levende Ind. af en ciadropsarus, der mala ansees som ef noget aberrant Ind. af denne Art; det afveg fra de normale Individer ved sin betydelige Storrelse, ved linliengede Kjover, ved skjwllenes ['dbredelse, samt endelig derred, at det nederste Tentakelprar paa Snuden manglede.

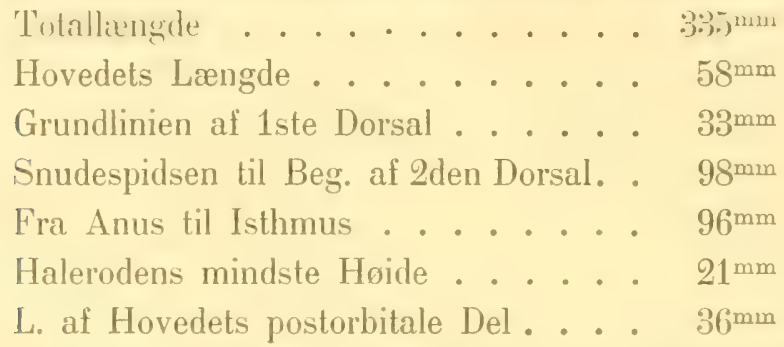

Individet var saaledes $\mathrm{i}$ Virkeligheden tri-cirrat. Af de 2 Fiostral-Cirri, fsom ogsaa i Larve-stadiel anlegges senere, end det ovre-Par), fandtes intet Spor.

Farven var helt hrun. Skjuelbekliedningen strakte sig frem Iil de hagre Nasehor, og beklaxdte Gjellememhranen; af Finnerne vare ogsaa Ventralerne skjælklædte.

Kjoverne vare forholdsvis lange, $81^{\text {mmo }}$. Mundspalten natede tilbage betydedight hagenfor (biet. Peetoralen havde 17 Straaler.

Exemplaret, der opbevares paa Chria.-Nuseet, var en gammel Ilan. med hrilender Testes. Lagtet sit abmome Udseende - temmer det dog i lluvedsagen narmest overens med ci. mustela.

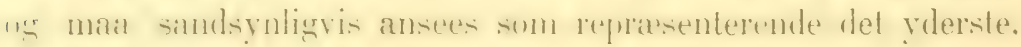
mest udviklede Stadium, som Arten idethele kan opnaa, et - Gadimn, som i Regelen ikle nates af de .typiske" (kijonsmodne) Individer:

Dette synes at antyde, at enkelte Individer af denne Art

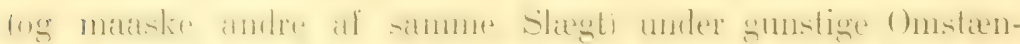

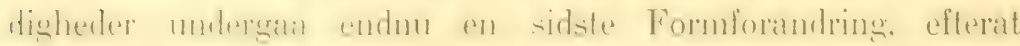

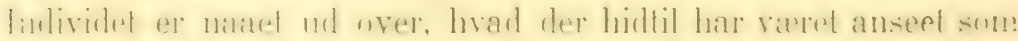
Grændsen for dets Udvikling. 
Fode. Hos Unger har jeg i Christianiafjorden fundet Ventrikelen fyldt af Crustaceer (Amphipoder).

Eldre Individer leve af forskjellige Slags Bunddyr. Et Ind. fra Christianiafjorden (16de Dec. 1857) var fyldt med Borster af en Aphrodite; et andet fuldroxent Ind. fra sanme

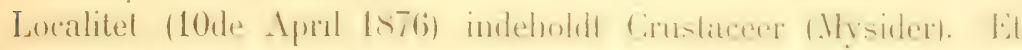

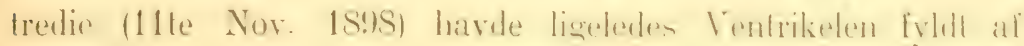
Palaemon og Mysis.

Gaidropsarus septemtrionalis, (tioll.) Lsi.).

Udbredelse. Af denne hidtil kun enkeltvis forefundne Art er

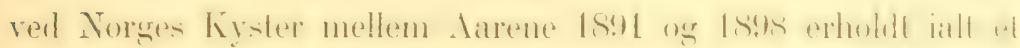
Dusin Individer, alle fra Strakningen mellem llammertust we Bergen. Af disse Individer ere de 4 smaa Unger; Resten ere yngre, eller mere udvoxede. Storst er det ene Typ.-Exemplar, hvis Totall. er $173^{\mathrm{mm}}$. De specielle Localiteter fra Norge ere folgende:

Finmarken. 2 Expl., begge spæde Unger, optagne ved Øxfjord i $1883\left(70^{\circ} 13^{\prime}\right)$. Totall. $45-51 \mathrm{~mm}$. (Chria.-Mus.).

Lofoten. 2 Expl.; det ene er et ungt Individ (Artens CoTypus), fra Bodø Aug. 1874; 'Totall. 100mm. Det andet er et

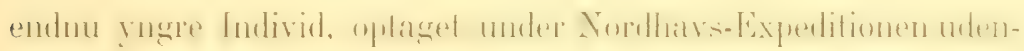
for Rost 2den Juni 1877; Totall. 69mm. (Chria.-Mus.).

Trondhiemsfjorden. 3 Expl. ere optagne i Fjorden udenfor Trondhjem 1880-83. Totall. 120 mm, $121 \mathrm{~mm}$, og $160^{\mathrm{mm}}$. ('Thjem.-Mus.) ${ }^{1}$.

Romsdalskysten. 4 Expl. Heraf ere 2 smaa Unger, fra Floro og Christiansund, optagne i 1871 og 1873. Totall, 44-4 $\mathrm{S}^{\mathrm{mm}}$. (Chria.-Mus.).

1 Et af disse opbevares nu i Museet i Hamburg, hvor jeg i 1895 havde Leilighed til at undersoge det. T'otall. var $121 \mathrm{~mm}$, Hovedets Længde $30 \mathrm{~mm}$ Legemet Hnide $21 \mathrm{~mm}$, Stratleantallet var: 2 D. 5\%; A. 41. 
Dermast ot udvoxet Exemplar, Han (Typ.-Exemplaret), fra Floro Juli 1873; Totall. 173 $\mathrm{mm}$. (Chria.-Mus.).

Enclelig et Hun-Expl. fra Aalesund 99de Marts 1896; Totall. $151 \mathrm{~mm}$. (Bergens Mus.).

Bergenshysten. 2 Ex., begge yngre: et optoges i Hjeltefjord bite Jan. 1898, Totall. 81 mm, et andet udenfor Bergen 7de Dec. 1897; Totall. 123 $\mathrm{mm}$. (Berg. Mus.).

Ldmactinger. De :3 senest erholdte Individer (1S96 95), der alle ere afgivne til Bergens Museum, havde, ifolge Conserv. Grieg1, følgende Maal:

\begin{tabular}{|c|c|c|}
\hline otallængde . . . . . & $81^{\mathrm{mm}}$ & $123^{\mathrm{mm}}$ \\
\hline ets Længde. & $19^{\mathrm{mm}}$ & $29 \mathrm{~mm}$ \\
\hline egemets største Høide & $11 \mathrm{~mm}$ & $18^{\mathrm{mm}}$ \\
\hline
\end{tabular}

Frre. Typ-Fxemplaret, og de fleste i Museerne opbevarede Individer, ere enslarvet graabrune, og uden Pletter; Undersiden er kun ubetydeligt lysere, især hos yngre Individer.

Et yngre Individ (Totall. 121 mm) fra Trondhjemsfjorden (nu i Hamburger-Nuseet), har en mork Plet paa 2den Dorsal hen mod Haleroden. Et endnu yngre Ind. fra Bergen (Totall. S1mm, har, ifolge Conserv. Grieg, langs Siderne en Rakke runde lyse Pletter, men er iovrigt, ligesom det ovenfor nævnte. normalt farvet.

Tilholdssted. Den Dybde, hvorpaa denne Art har været erholdt. har wftest varieret fra 30-90 Meter. Lit Ind. optoges paa Dyhsagn (snne) i Trondhjemsfjorden i Slutn. af Oct. 1850 fra en Dybde af 270 Meter.

Forplontuing. Et Individ (Totall. 151 $\mathrm{mm}$ ), fanget udenfor

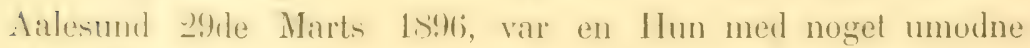
liogn i ()varierne. Sandsynligris vilde Ludividet have veret grdefærdigt i April eller Mai.

1 Bergens Museums Aarbog 1898, III, p. 12. (Bergen 1899). 


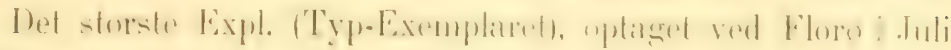
1873, var en Han med fuldt.udvoxede Testes, men disse vare hvilende, og syntes netop udgydte.

Fode. Hos de 2 Typ.-Exemplarer indeholdt Ventriklerne Cruslaceer, det mindre Expl. lar Budn an Mimpulyle pusiola, den store Han fra Floro en Galathea nexa. Det ovenfor

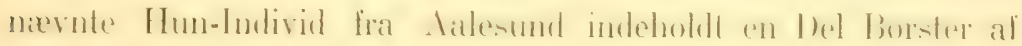
en Annelide.

Gaidropsarus argenteolus, (Mont.) 1818.

Gadus argenteolus, Mont. Mem. WVern. Nat. Hist. Soc. Vol, II, P. 449 (1818). Yngel-Stadiet.

Motella tricimata, Nilss. Prodr. Ichthyol. Scand. p. 48 (1832), (nec Brünn).

Motella vulgaris, Yarr. Brit. Fish. Ed. I, Vol. II, p. 186 (1836).

Onos maculatus, Lilljeb. Sveriges och Norges Fauna. Fiskarne. 2 Del, p. 164 (1891).

Lidbredelse. Tilhorer Landets Sydvestlyst fra Lindesinass idetmindste op til Aalesund.

Skjønt dens Udbredelse ved Norges Kyster synes at være forholdsvis indskranket, forekommer den paa enkelte strakninger. siasom mellem Stavanger og Bergen, temmelig talrigt. I Bergensfjordene er den alminlelig, og torvfores i lasgelen dixglig i bergen i Sommer- og Hostmanederne: salaledes kunde jeg pila en enkelt Dag (side Sept. 1S!) her finde et Tusin styker. alle fuldt udvoxede. Den kaldes her Tang-Brosme.

Ogsaa i de ydre Dele af Stavangerfjordene synes den at viere temmelig hyprig. og torvfores jevnligh i stavanger og Haugesund.

Edenfor disse Localiteter kjendes hol smente Individer. Et

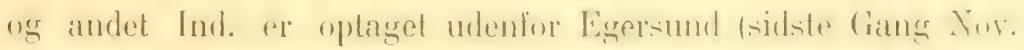

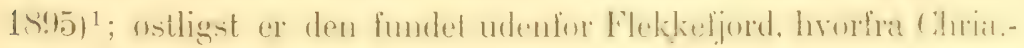
Museet eier et stort Expl., fanget 1Sde Marts 1898.

1 Hos dette Individ er den ene Nasal-Cirrus kloftet.

Vid.-Selsk. Forh, 1903. No. 3. 
Tordig-t a den fundet gientagne Crange udenfor Aalesund; men det a sundoynligt, at den forckmmer i den ydre Slijergiand endnu liengere mod Nord. Den er dog endnu ikle hemitrliet i Trondhjemsforden, ligesom Angivelser fra NordlandsKysten ere usikre.

Storrelse. De fleste erholdte Individer ere middelsstore. med coll Totall. af omkr. 4(0)mm. Eit Ind., som Chrit.-Nuseet modtug

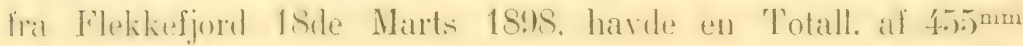
(IIoredets L. 102mm). Bergens Mus. eier et i Omegnen fanget

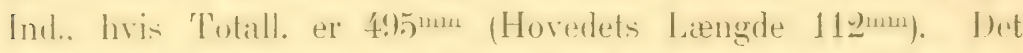
-torste af mor undersogte Lxpl. fra Norge er fanget i Bergens Omegn i 1877, og ophevares ligeleden i Chria.-Museet; dette har en Totall. af $518^{\mathrm{mm}}$ (Hovedets Længde 113mm, Legemets Høide $80^{\mathrm{mm}}$ ).

Fode. Denne synes hos os hovedsagelig at bestaa af Fisk ug Crustaceer, men de fleste til Nuserne indlobne Exemplaren have veret tomme. Itos et Par middelsstore Expl. (Tulall. 4201)

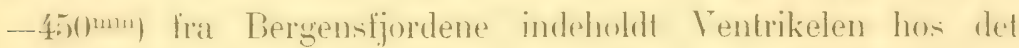
ene flere hele Expl. af Portumus depurator; det andet indeholdt "n ung Cancer pagurrs, sant en Fisk, Liparis montagui ${ }^{1}$.

Forplantning. Alle af mig hidtil undersogte Exemplarer

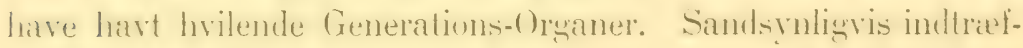
fer Legetiden i Sommermaanederne.

Yngel aller Unger, der med Sikkerhed hate tilhort G. aigenteolus, we hidtil aldrig undersogte fra vore Farvande. Lin Del

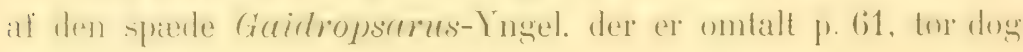
have tilhort denne Art.

Raniceps raninus, (Lin.) 1766.

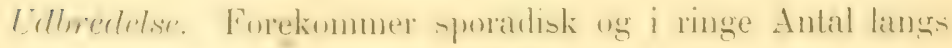
de sydlige og vestlige Kyster op til Trondhjemsfjorden.

${ }^{1}$ I Ventr. af dette Ex, af Liparis fundtes vel vedligeholdte Individer af litorale Amphipoder (Capreller og Podocerus anguipes). 
Hyppigst synes den at erholdes i Christianiafjorden, hvor jeg darlig lar fundet enkelte Individer torvforte i Christiania. især om Hosten.

Ligeledes er den ikke sjelden i Bergensfjordene; paa Christiansunds Museum findes et Expl. (fangel i Oct. 1898), hvis T'otall. er $290^{\mathrm{mm}}$, det storste Exemplar, jeg har undersogt fra de norske Kyster.

I Trondhjemsfjorden ere ligeledes flere Individer i Aarenes

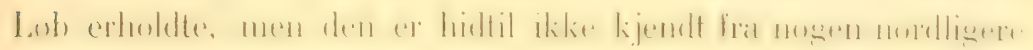
Localitet.

Fode. Hos saagodtsom alle af mig hidtil undersogte Expl.

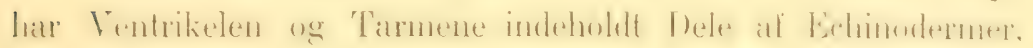
saa fint knuste, at de have fyldt 'Tarmene med Kalkvand. Et

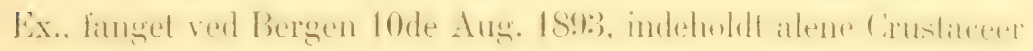
(Galathea dispersa).

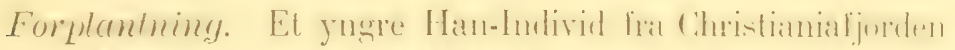

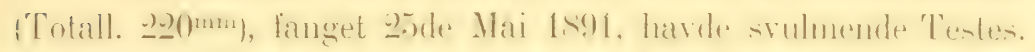

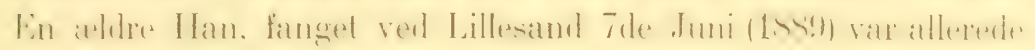
udgydt, men havde endnu opsvulmet Anus.

Sandsynligvis indtræffer hos os Legetiden i Mai eller Juni.

Brosme brosmé, (Ascan.) 1772.

Levescet. Som andre Gadider lever den stimevis, og fanges

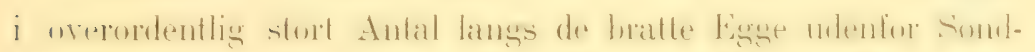

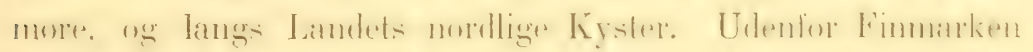
erholdes den ligeledes i store Mængder; i April 1883 fik en

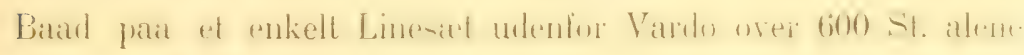
af denne Art.

Den opnaar i Finmarken en betydelig Storrelse, og Exemplarer ere fangede med en Vægt af omkring 10 Kilogr.

Forplantning. Gydetiden falder ved Landets Vestkyst i Mai-Juni. Den gaar da op paa det grundere Vand, og kan 
trafles paa mutr. :30-40 Favne (50-80 Meter). Hos et Ind. med en Tulall. al $79010 \mathrm{~mm}$, fanget ved Rodr i Ilelgeland 2den Mai (190:3), ogr indsentt til Chria.- Museet. indeholdt Rognssekken omtr. 1,300,000 Eg.

Fode. Angives af Fiskeme at besta af lorskjellige Arter Crustaceer, undertiden Cephalopoder.

Hos de Exemplarer, som Dr. Nordgaard har undersignt i Loloten Vaaren 1897, fandt han iscer Bund-Crustaceer, saasom Lithodes maja, hvis Torne kunde sees fra Ventrikelens Iderside, uden dog nogensinde at gjennemtrænge dens Vagge. Ligeledes har han hos dem fundet Annelider (Leodice). Hos Exemplarer fra Herlofjord ved Bergen (Aug. 1897) fandt han ligeledes Crustaceer (Hippolyte, Galathea).

Prof. Lilljebory har ligeledes hos de Exemplarer, som han har undersogt (paa Norges Vestkyst), fundet storre Crustaceer, især Nephrops norvegicus.

Hos et stort Expl., fanget ved Andenæs i Vesteraalen 6te Juli 1594, fandt jeg en Egkapsel af Chimaera; ifolge Fiskemes Angivelse var dette $\mathrm{Eg}$ oftere fundet i Brosmens Navesiek paa denne Localitet.

Ligesom G. morrhna sluger den sandsynligvis nasten alt. som synker forbi den gjennem Vandet ${ }^{1}$.

\section{Fam. Ammodytidae.}

Ammodytes tobianus, Lin. 1766.

Udbredelse. Smaa-Silen er den ved Norges Kyster talrigste Art, og er ulbredt isar paa sandige Localiteter fra de sydlig-te. Dede op til Varangerfjorden. P'a flere Steder i de mordlige Landistele mugion den en skattet Agn for forskjellige Torske. Arter.

1 Saledes blev i Mai 1893 et Ind. fanget paa Bankerne udenfor Aalesund, i hvis Ventrikel fandtes en Tollekniv, omtr. $235 \mathrm{~mm}$ lang (9 Tommer), hvilket var lidt over Halvdelen af selve Individets Længde. 
Yngelen findes ofte i stort Antal paa Sandbund paa ringe Dyb om Sommeren i Juli og August Naaneder; den har paa denne Tid en Langde af $35-45 \mathrm{~mm}$.

Fode. En Del unge Individer, oplagne i Mundingen al Grændse-Jacobs Ely i Varangerfjorden om Vaaren, havde Ven-

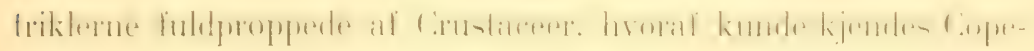
poder (Harpacticider), samt Dele af Mysider.

Hos udvoxede Individer, optagne i Ilsvigen i 'Trondhjems-

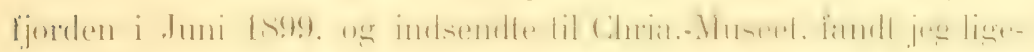

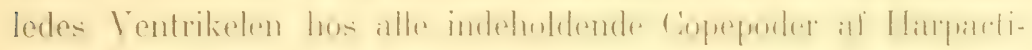
cidernes Familie (saasom Itlya furcatcr), samt en og anden

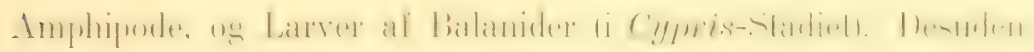
indeholdt flere af dem spæed Fiskeyngel, som det syntes af Gobiider.

2 af de ovennævnte Individer (Totall. $120-125^{\mathrm{mm}}$ ) vare Hanner med opsvulmede 'Testes.

Ammodytes lanceolatus, Lesauv. 1824.

Udbredelse. Denne Art, Stor-Silen, forekommer i Norge i ulige ringere Antal, end foregaaende, og trefles, som det synes, oftest blot i enkelte Individer, eller i smaà Selskaber. De luld

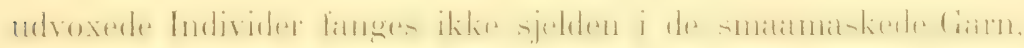
som trækkes i ringe Dybde efter mindre Gadider, Smaasild, og anden Smaafisk.

Tidligere var denne Art ikke sikkert kjendt nordenfor 'Trondhjemsfjorden, men har $\mathrm{i}$ de seneste Aar vist sig at forekomme idetmindste op til Tromso $\left(69^{\circ} 39^{\prime}\right.$ N. B.). Et Par Individer ere i Nitti-Aarene indlobne til T'romso Museum, deriblandt et fuldt

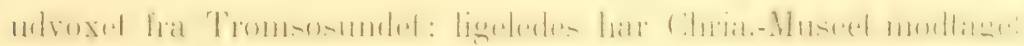
et Expl., fanget ved Balstad i Lofoten 20de Fehr. 1896. Ogsan ved Rodo i Helgeland, samt ved Bodo er denne Art fundet i store Exemplarer.

Storrelse. De storste Expl., som jeg har undersogl tra Norge, ere 2 i Chria.-Museet ophevarede Exemplarer, hvoraf det 
me. optaget ved Langesund :30te Mai L900, har en Totall. af

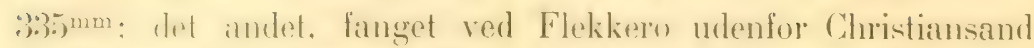

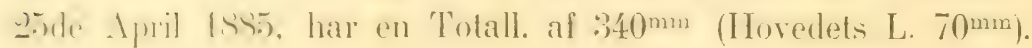

Forplontning. Et Tnd. med en Totall. af $309^{\mathrm{mm}}$, fanget wh Mos- i Christianiafjorden 15de Sept. 1897, have Ovarieme fylde med nixiten moden Rogn, der sandsynligris vilde have været gydefærdige $\mathrm{j}$ October.

\section{Ammodytes cicerelus, Raf. 1810.}

Udbredelse. Denne Art er hidtil blot fundet i nogle faa lixemplarer ved Landets Vestlyst paa 2 Localiteter. nemlig i Figrdene udenfor Bergen, og ved Grip udenfor Christiansuml $\left(63^{\circ} 15\right)$.

Det forste Expl. Arten hlev, som bekjendt, furste Gang paiavist red vore Kyster af Prof. Lilljehorg, som optog et rngre Ind.

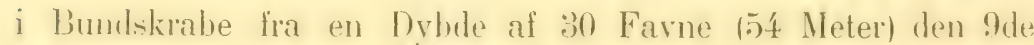
Aug. 1858 ved Grip udenfor Christiansund ${ }^{1}$.

Exemplaret havde en Totall. af $126^{\mathrm{mm}}$; Legemets storste

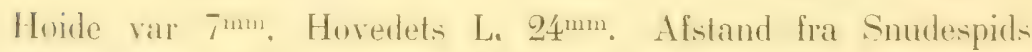
(Underkjerens) til Anus var $71 \mathrm{~mm}$, til Dorsalen $34^{\mathrm{mm}}$. Legemets Insde indehondter saaledes hos dette Individ 18 Cange i Total. længden.

Prof. Lilljeborg ansaa Arten, som forekom i Selskab med A. tobianus, som normal og stationær paa denne Localitet.

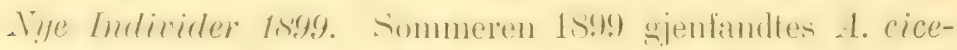
relas under de af Bergens Muscum foretagne skrabminger i Lercem-fjurlene. Al de: fumlne Expl. vall det rue af simme Storrelse, som Exemplaret fra Grip, de ovrige yngre ${ }^{2}$. Ved

Exemplaret blev noiere omhandlet i 1891 af samme Forf. i "Sveriges och Norges Fauna. Fiskarne". B. 2, p. 2928 (Upsala 1891). Som en Til. vaxt til den norske Fauna har jeg omhandlet Exemplaret i Archiv f. Math. og Naturv. B. 19, No. 8 (Chria. 1897).

2 Det mindste af disse opberares nu i Chria.-Musect. 
Dr. Appellöls Velvilje har jeg havt Leilighed til at undersøge disse Exemplarer i Bergens Museum.

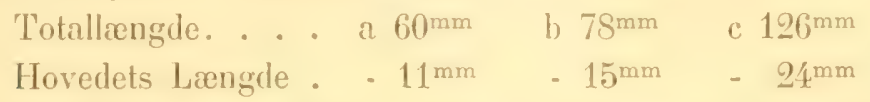

Hos det storste Individ har Underkjæven en Liengde af $10,5^{\mathrm{mm}}$, og Pectoralen en Længde af $9,5 \mathrm{~mm}$. Dorsalen begynder

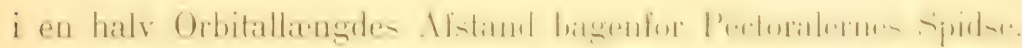

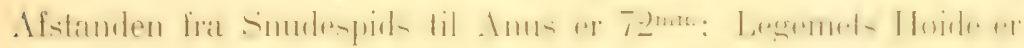
$\mathrm{S}^{\mathrm{mm}}$, og indeholdtes saaledes 15,7 Gange i 'Totallængden.

De 2 yngste af disse vare optagne ved Solsvig udenfor

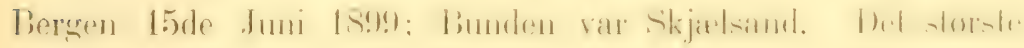
toges omtrent samtidigt i Hjeltefjorden.

\section{Fam. Macruridae.}

\section{Macruxus rupestris, (Müll.) $1776^{1}$.}

Udbredelse. Langstjerten forekommer, tildels i stort

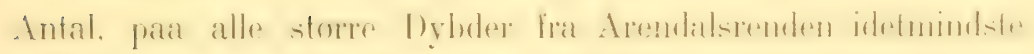
indtil Nordlands Grændse; men udenfor de Steder, hvor der

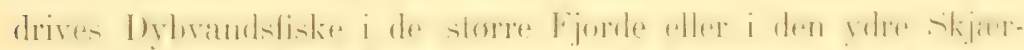

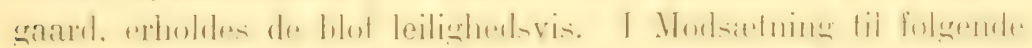

1 Artens forste videnskabelige Benzevnelse er, som bekjendt, Coryphacnoides rupestris, Gumn. 1765. Saavel i Afhandlingen "Norges Fiske" (1875), som i de senere Supplementer, er Nomenclaturen ikke fort liengere tilbage, end til 12te Udgave af Systema Naturae, 1766. Den neste Forf., der efter Gunnerus kjendeligt beskriver Arten, er Müller i Zoolorgice Danice Prodromus, p. 43 (1776).

Saafremt alle for Tiden svevende Prioritets-Sporgsmaale engang skulde komme til nogen endelig Losning, og der opnaaedes fuld Enighed om, at Nomenclaturen skulde fores tilbage til Aaret 1758, (til 10de Udgave af Systema Naturae), maatte Slagtsnavnet Coryphaenoides, Gunn. 1765, optages for denne Art og for alle narstanende Arter, der hidtil ere opforte under Slagten Macrurus, Bloch 1786, (saledes ogsaa M. berglax; der neppe generisk kan skilles fra Coryphaenoides rupestris).

$\mathrm{Og}$ saafremt et Familienawn skal dannes af den aldste bekjendte Slecgts Navn inden Familien, maa fremdeles denne Families Narn (Macruvidae) i Overensstemmelse hermed forandres. 
Art tranger den dybt ind $\mathrm{i}$ de storre Fjorde, og er saaledes, som det symes sirlig talrig udenfor Bergens Stift og i Trondhjemsfjorden.

Liengit mod Ost forekommer den udenfor Landets Sydkyst i den sitilialdte Arendalswende, og her $\mathrm{i}$ saa stort Antal, at den af Fiskerne fra Langesund kan fanes i Hundredevis paa Linerne, og den er her fuldt stationær og ynglende.

Al den. Talrighed paa disise Dybder maa vere helydelig,

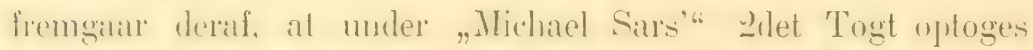
den Tke Seph. 1901 i 3 Trawlkast ndenfor Aremdal, i onkr. 60 Kilom. Astand fra Land, ialt S45 Sykker, (hworaf i 1 Kast 2 s1 Si., $i$ et andet 56 Si.). Dyblen varierede her mellem 300 og 555 Meter.

I Christimiafjurden ere jevnlig Exemplarer erholdte saa langt inde. sim ved Horten og Holmestrand, hvor Dyhden kan gaa ned til over 200 Meter, og den synes her, som overalt i sin Optræden. al vare til an vis Gand afhangig af sin Hovednating. I'andalus borealis.

Nordenfor Trondhyem-fjorden el den hidtil ikke fundet len-

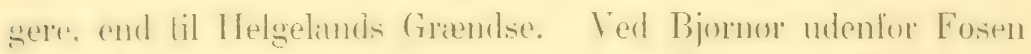
lagen den emdnu tildels i stort Antal paa Linerne: i 1890 modtog Chria.-Mus, et Expl. fia denne Localitet, hvor 20 St. vare fangerte ved samme Leilighed, men den angaves tilliges som tilligere ukjendt paa dette Sted.

$M$. mpestris synes idethele at hore til de Arter, der for

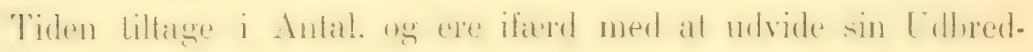
ningskreds mod Nord og Syd.

Storrelse. Det storste (complette) Expl., som jeg har kunnet

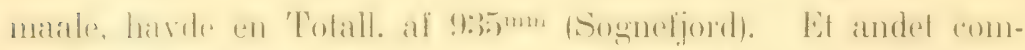

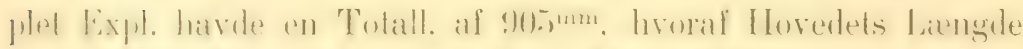

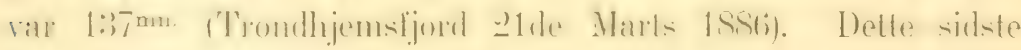
Expl. havde følgende Straale-Antal:

1 D. 11; 2 D. 183; A. 187.

Et andet Ind., som Conserv. Storm har undersøgt fra 'Trondhjemsfjorden, havde en Læungde af over 1 Meter. 
Pseudo-Candal. Et ikke ringe Antal af de erholdte Individer har havt Halespidsen afbrudt, og overalt, hvor denne

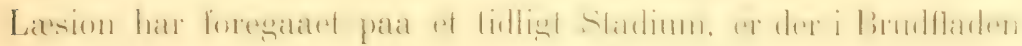
reproduceret Straaler, flere eller færre efter dennes Hoide.

Hos et Expl., optaget udenfor Aasgaardstrand (i Christiania-

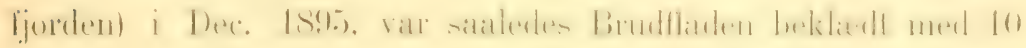
Straaler, der havde den anselige Læengde af indtil $65^{\mathrm{mm}}$. Brudfladens Hojde var her $10^{\mathrm{mm}}$.

Den bredeste regenererede "Caudal" havde el Expl. fra

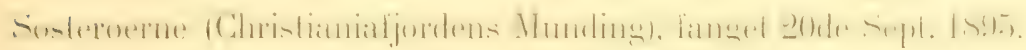
Brudfladen, der havde en Hoide af over $20 \mathrm{~mm}$, havde reproduceret omtr. 20 særdeles tætstaaende og spinkle Straaler, der

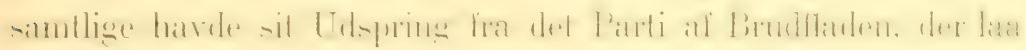
umiddelbart udenfor den sidste Hvirvel. (Hoiden var her omtr. $10^{\mathrm{mm}}$ ). De længste Straalers Længde var hos dette Expl. omtr. $35^{\mathrm{mm}}$.

Andre regenererede Halespidser have havt et noget mindre Straaleantal, tildels saaledes, at de danne ligesom en normal Caudal, kun noget bredere, end denne.

Levemaade. Den Dybde, hvorpaa Individerne oftest erhol-

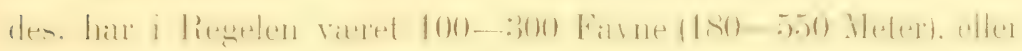
derover. Kun sjelden gaar den op og langes paa det noget grundere Vand; Chria.-Museet har saaledes modtaget et Ind.,

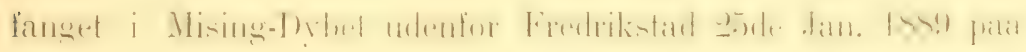
160 Meters Dybde. De fleste have værel langede paa Line, (eller med Dybvands-Redskaber), og have i Regelen været udvoxede, eller nær derved. Paa disse Dybder have de utvivlsomt sit 'Tilhold i store Stimer, og leilighedsvis kan, som ovenfor' nævnt, fanges et stort Antal i samme Linesæt.

Af Fiskerne betragtes den som vardilos, og bringes sjelden tillands med den ovrige Fangst.

Forplantning. Legetiden indtræfler hos os on Hosten, eller $\mathrm{i}$ de forste Vintermaaneder.

Den Sde Octoher 1886 modtog jeg et Dusin Individer, alle

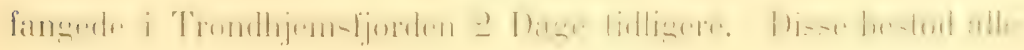


af drargtige Ilumner. der vare midt $i$ sin Grdetid: et var helt

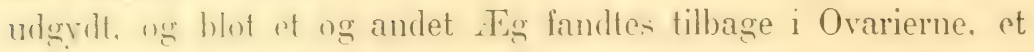
andet var halveyit: hos alle de ovrige vare Rognmassen tilstede i gydefærdig Stand.

Da alle de ovemnærnte drægtige Individer vare fangede paa samme Linsiet, og da der ingen Han fandtes deriblandt, synes dette at antyde, at de grdefærdige Hunner danne sirskilte Stimer.

lit andet Individ i Chria.-Museet fra Arendalsrenden (udenfor Christiansand). fanget 1Sde October 18s?. havde ligeledes temmelig los Rogn.

Den samme Gydetid havde sandsynligvis et Ind., fanget mellem Rordskjær og Tisler (Hvaler) 21de Oct. 1893, og undersngt af Conserv. Hanson, idet dette var paa denne Tid udgydt.

Ograa i Larets sidste Maaneder kan der findes rognfyldte Individer. En Hun, fanget udenfor Langesund 129te Nov. 185… indeholdt saaledes Rogn, der endnu ikke var gydefærdig.

Fggene. Rognmassen blev trellet hos 3 af de storste Individer handt de ovemnarnte fra Trondhjemsfjorden, fangede side Oct. 1886.

Totall. $830 \mathrm{~mm}$. Rognenes Antal omkr.15,100 St.

$$
\begin{aligned}
& \text { - } 870^{\mathrm{mm}} \text {. - } \quad \text { - } \quad-16,500 \text {. } \\
& \text { - } 890^{\mathrm{mm}} \text {. - - } \quad \text { - } 12,000 \text {. }
\end{aligned}
$$

Antallet symer saaledes gjennemsnitlig bos udvoxede Individer at rare omkr. 14.000 Stykkrr. Eggrets Diameter er omtr. $1,8^{\mathrm{mm}}$.

()varierme are store, ug dobhelte, og km paa et ganske ringe Strkke sammonvoxede; of storre Parli af dem ere derimod ind-

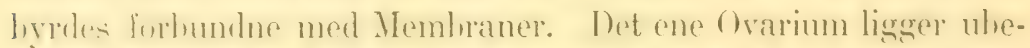
trodelight foran det andet: deres Laengde ar hos de storste moder-

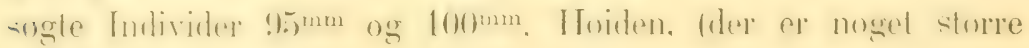
end Bredden) omtr. $35 \mathrm{~mm}$.

Unger. De mindste Unger, der hidtil ere opbevarede fra de norske Kyster, have havt folgende Maal: 


\begin{tabular}{|c|c|c|c|c|c|c|c|}
\hline & & & & Totall. & Hovedets L. & Øiets Diam. & $\begin{array}{c}\text { Snudespids } \\
\text { til Anus. }\end{array}$ \\
\hline a & . . & . & . & $107 \mathrm{~mm}$ & $21 \mathrm{~mm}$ & $6^{\mathrm{mmm}}$ & $25^{\mathrm{mm}}$ \\
\hline 1) & . . & . . & . & $123 \mathrm{~mm}$ & 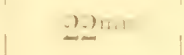 & $?$ & $30: m \ldots$ \\
\hline r. & . . & . . & . & $220 \mathrm{~mm}$ & $43^{\mathrm{mm}}$ & $14,5^{\mathrm{mm}}$ & $55^{\mathrm{mm}}$ \\
\hline
\end{tabular}

Disse ere alle optagne $\mathrm{i}$ Arendals-Renden, de 2 forste $^{1} \mathrm{i}$

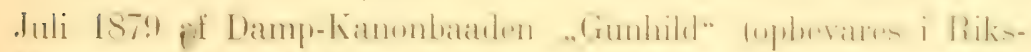

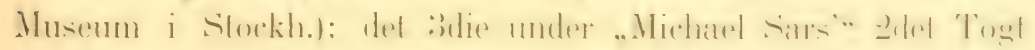

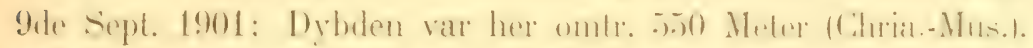

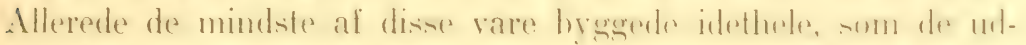

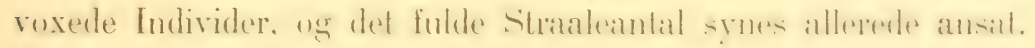

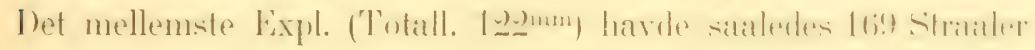
i Analen.

Fode. Ventrikelen hos de talrige Exemplarer, jeg i Aarenes

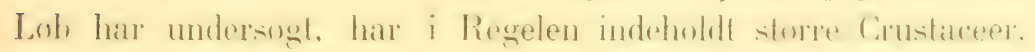

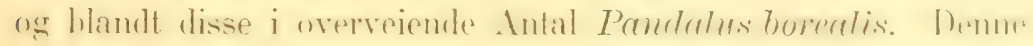

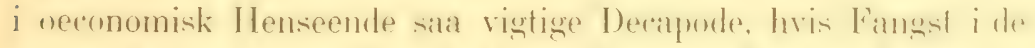

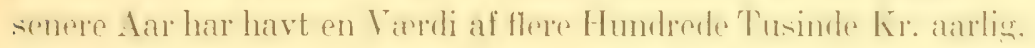

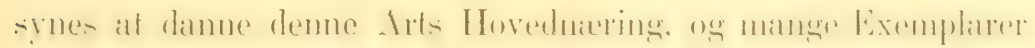
have Ventriklerne fuldproppede af denne Art (ofte dog blot et enkelt Ind., eller et Par St.).

Af andre Crustaceer fra dens Ventrikel kan nævnes Pan-

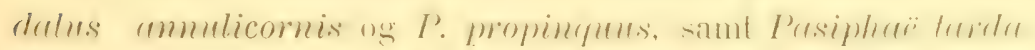

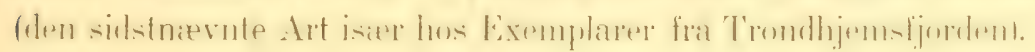

Hos Exemplarer fra Bergensfjordene har Dr. Nordgaard

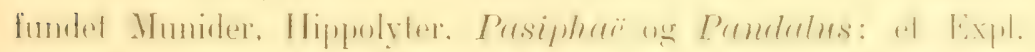

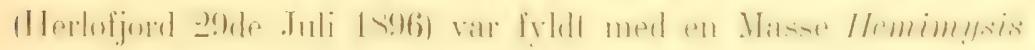
abyssicola.

Macrurus berglax, Lacep. $1800^{2}$.

Udbredelse. Is-Galten er den arctiske Repræsentant blandt Nacruridernes talrige Arter, og har hos os sin fornemste Ud-

1 Disse ere udforligt beskrevne (18S4) i 2 det Hoved-Supplement lil Norges Fiske, 1879-83. (Nyt Mag. f. Naturv. 29 B., p. 97).

2II. fabricii, Sundev. 1810. 
bredelae i Istarvet udenfor Fimmarkens og Tromso Ants Kyster. Invigt tranger den ogsia sondenfor det arctiske Omraade, og tages leilighudsvic saa langt mod syol, som red Kysterne af Bergens Stift.

I Finmarken har den været kjendt siden 1837, da Lovén lomgle det lorste europaiske Expl. lar Hammerfest til RiksMnsenm i storkholm. Senere sjenfandles den i Varangerfjorden og paa Dybderne udenfor Vardø, hvor det har vist sig, at den

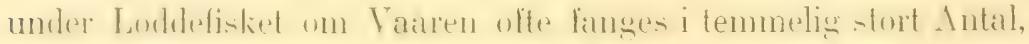

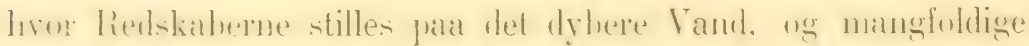
Exemplarer are herfa i Aarenes Loh indlobne til Museerne.

I Vest-Finmarken kan den ligeledes paa visso Fiskepladie mholdes i sture Antal, saasom i Porsangerfjorden, ved Ingor og ved Gjesvær, samt fra Dybderne udenfor Hammerfest.

sandornligrio forekommer Is-tialten overalt langs kisten.

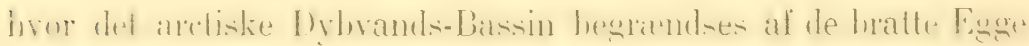
i forskjellig Afstand fra Land.

Sommeren 1894 fandt jeg den saaledes yderst talrig paa

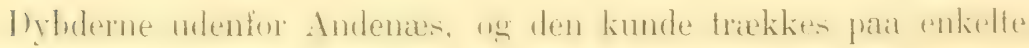
Dage $\mathrm{i}$ hundredevis af de her stationerede Fiskere.

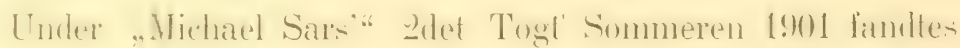
den ligeledes at være talrig ved de samme Dele af Kysten, og mange Lxpl. erholiter under do af Dr. IIjort her furetagne Fiske. Forsog udenfor Andenæs i Aug. s. A.

Ogsaa fra andre Puncter i Vesteraalen ere Exemplarer kjendte (saaledes fra Borholmen 31te Juli 18s8, og fra Bo Juni 1901).

Fra Værene ved Nordlands Kyster vides den endnu ikke omtalt, men det kan neppe betvivles, at den her forekommer.

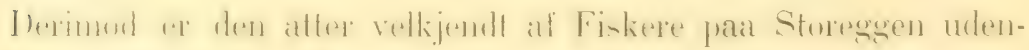
for Aalesund, og Bergens Museum har i de senere Aar gjen-

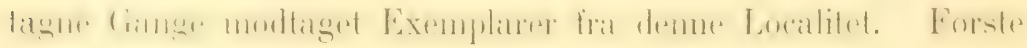
Gang indlob et Exemplar herfra i Sept. 1896, og Aaret efter flere. Dette er det sydligste Punct, hvor Arten vides bemærket hos os $\left(62^{\circ} 40^{\prime}\right.$ N. B.). I Arendalsrenden er den endnu ikke fundet. 
1903.] MEDDELELSER OM NOIGES FISIE I AARENE 1884-1901.

Storrelse. Det mindste Expl., som jeg har seet fra Norge,

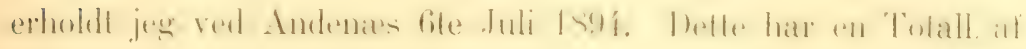
$449^{\mathrm{mm}}$ (Hovelets L. 105 $\mathrm{mm}$ ). Det storste Individ har Chria.-

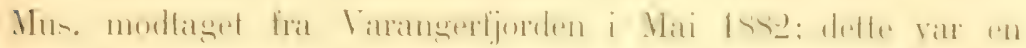
Hun med en Totall. af $935^{\mathrm{mm}}$ (Hovedets L. 174mm).

Navne. Ved Vardo benrevnes denne Art Is-Galt; ved Andenæs kaldes den Hav-Mus; (det sidste Navn anvendes

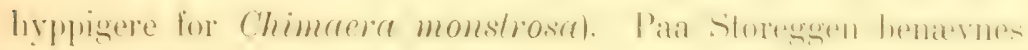
den, ifolge Dr. Grieg, Log-Fisk.

Levemaade. Den forekommer sjelden paa ringere Dybde,

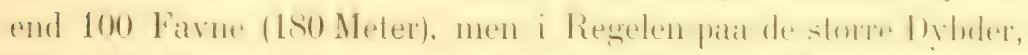

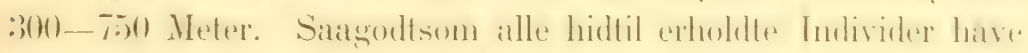

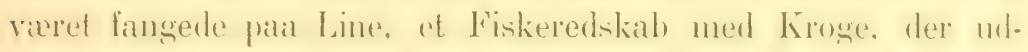

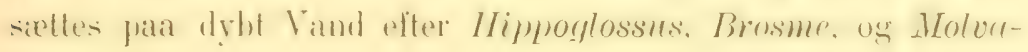
Arterné.

Ligesom foregaaende Art færdes den i Dybet i store Stimer. som wentor nawnt, erholdt en enkelt Fisker pata en eneste Nat ved Andenæs (6te .Juli 1894) omtr. 100 St., da hans Line ved el

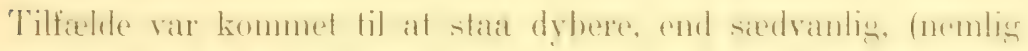
paa over 500 Meters Dyb).

Den ansees som værdilos, og bringes ikke tillands at Fiskerne. Friskfangede Fixemplares alsonder an werententlis Nasse Slim.

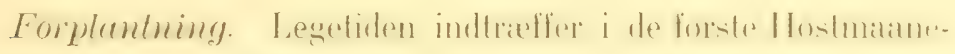
der, i August eller September.

Et Individ, som Chria.-Museet modtog fra Borholmen i Vesteraalen, fanget :3te Juli 18SS, havde Ovariet fyldt med

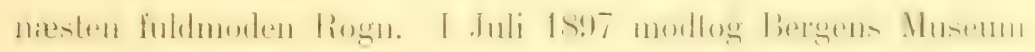

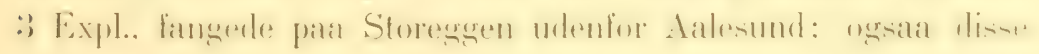
indeholdt Rogn, der vare fuldmodne.

Endelig kan anfores, at blandt 3 Individer, der optoges under

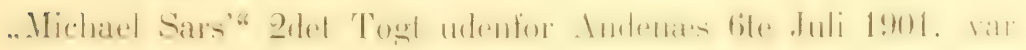
det storste en Hun, hvis Rogn vare næesten fuldmodne, og som sandsynligvis vilde have gydt i August eller September. 
Iln Individer, langede i Vaarmatnederne (April og Mai). har Rognen endnu været temmelig fast.

Tingenes Antal hos del orennernte (nixsten gydefierdige)

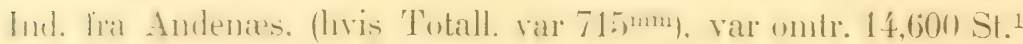

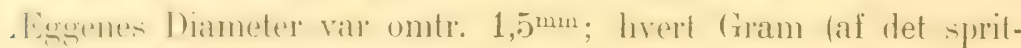
lagte Individ) indeholdt omtr. $365 \mathrm{Eg}$.

Foden bestaar al større Crustaceer, Echinodermer (især Ophiurer), Mollusker, samt Fiske.

Hus Lndivider fra Vardo, fangede i Sommemnamederne, har jeg funted Tentrikelen i Regelen tom. Enkelte Lndivider havdte den fildt al Pandalus borealis, hos andre fandtes Dele af Burriner og Fusus; hos ef Wxpl. (finget i Januar) fandtes Lodde (Mallotus villosus).

Et vonge Ind., fanget ved Andenas lite Juli Is!), indeholdt alene Echinodermer (knuste Ophiurer).

IJos a af Dr. Grieg undersogte Exemplarer (frat Storeggent) fander I'andalus ong Ophiacantha abyssicola. (hos det ene aleme den sidstnæevnte Ophiur).

\section{Fam. Plenronectidae.}

Mippoglossus hippoglossus, (Lin.) 17tili.

Forplantning. Kveitens Gydetid indtræffer regulært i Aarets forste Maaneder. Fra October til Januar er dens liogn fant; i ipril lates oftest udgrolte Individer. Som den mormale dividetid kim ansedes Marts og April, men det er sandsynligt, at enkelte Individer gyde $\mathrm{i}$ de senere Vaarmaaneder.

Dette Antal, som er fremkommet efter gjentagne Tællinger, stemmer ikke med Griegs Angivelse i Berg. Mus. Aarb. 1898 (No. III, p. 14). Hos det af ham undersogte Expl. (Storeggen Juli 1897), hvis Totall. omtrent var den samme, som hos det ovennæunte Expl. fra Andenæs, fandtes $530 \mathrm{Ag}$ pr. Gram, og da Ovariets Vægt var 67 Gram, fremkom et Antal af omtr. $35,000 \mathrm{Ag}$. Fratrekkes Vægten af Ovariets Vægge og Membraner (omtr. 8 Gram), bliver det samlede Antal her lidt over 30,000 St. 
Paa demne Tid foregaar en Vandring fra Dybet ind mod de grundere Steder, og de kunne herunder træffes paa saa ringe Dybde, som paa 10-15 Favne (1S-2S Meter). Det er sandsynligt, at Gydningen foregaar paa disse moderate Dyb, men herom mangle endnu sikre Iagttagelser.

Under denne Periode kan den undertiden træffes svommende om i selve Vandskorpen; et saadant Ex., hvis Vægt var 110 Kilogr., blev dræbt 14de Juni 1899 paa Nordeggen.

Yngel. Drivende Agg, der antoges at tilhore denne Art, ere

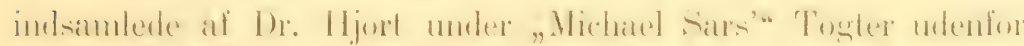

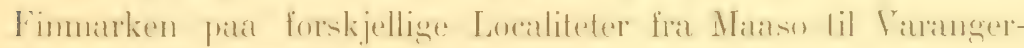
fjorden i Mai 1901.

Et Yngel-Individ (Chria.-Museet), hvis Totall. er $31^{\mathrm{mm}}$, optaget af Prof. G. O. Sars i det overste Vandlag udenfor Chri-

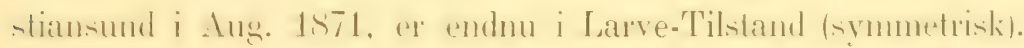

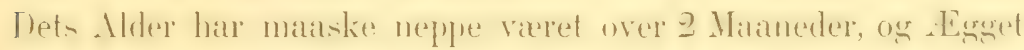
har saaledes været gydt omtrent i Mai eller Juni Maaned ${ }^{1}$.

Unger, med en Totall. af $70-100^{\mathrm{mm}}$, ere af Dr. Knut Dahl ${ }^{2}$

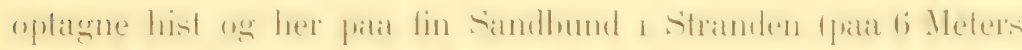

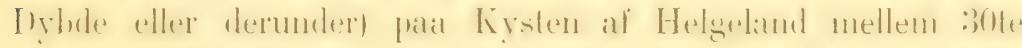

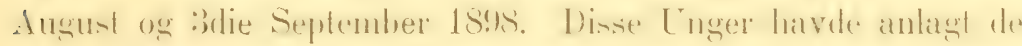
ieddres Legenn-form, men Farven val i enkelfe Henseemder elen-

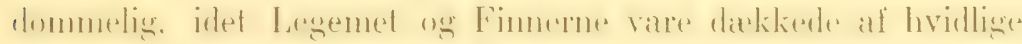
eller morkere Pletter, ligesom hele Legemet var forsynet med halvmaaneformige mørkfarvede Ringe.

Det er sandsynlight, at disse Uneger tilhorte liollige Airskuld. og vare omkr. 6 Maaneder gamle.

Unger med en 'T'otall. af $170-180^{\mathrm{mm}}$, som jeg har fundel

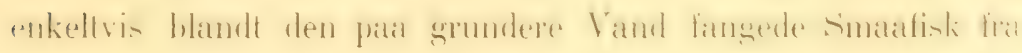

1 Dette Ind. er noiere beskrevet (1874) i min Afhandling: "Norges Fiske", p. 134; senere af bildet (1893) af Dr. Pelersen i "Indberetn. fra Danske Biologiske Station" IV, 1893, Pl. II, Fig. 20. (Kjobenhavn 1891).

2 Kgl. Norske Vid. Selsk. Skr. 1898, No. 10, p. 57, Pl. I, Fig. 2. 
Christianiafjorden i Mai og Juni, have sandsynligvis været 1 Aar gamle.

Storrelse. En Del i de senere Aar undersøgte Individer, hris Storrelse ansiaes som usæedvanlig, havde folgende Mnal:

\begin{tabular}{l|c|c}
\hline & Længde. & Vægt. \\
Gjæsvær Vaaren 1896... & - & 160 Kilogr. \\
Lofoten 15de Febr. 1899... & - & $175-$ \\
Tanafjord Vaaren 1897. . & $4700^{\mathrm{mm}}$ & $180-210-$ \\
Udenfor Hammerfest 1884 . & - & $240-$
\end{tabular}

Et Exemplar er endvidere kjendt fra Nordland, hris Vagt var 170 Kilogr. uden Indvolde; (hos dette Expl. veiede Hovedet $27 \mathrm{Kg}$.$) . Hanmerne ere i Regelen de mindste, og naa sjeldnere$ over 60 Kilograms Vægt.

Irasen. En markelig, og hurligt indtradende Farveforandring er iagttaget hos de levende Individer af denne Art. - Saasmart el Individ (isæer de storre) kommer op paa grundere Tand, staar det gjerne med Hovedet skjult i Laminarierne, eller ved Siden af en stor Sten. Narmer der sig en Baad, og Fisken fiar (O) par deme, hliver dens Farve lidt efter lidt hlegere: og er Farven blevel triteligt lys, ved Fiskeren, at den er faerdig til at fly ${ }^{1}$.

Iovrigt er Kveiten af en yderst træg Natur; de unge Individer liunne ligge en hel Dag uhevingeligt nedgravede i Sanden. De ere yderst seiglivede, og kunne ligge timevis levende i Baaden.

Fomblimger. I'aa Storeggen (udenfor Aalpsund) er i NittiAarene langet at Ind. hoori landtes redhengende Dele af et snore (Line) we en liskekrog, der var al fransk oprindelse.

1 Meddelt af E. Havno, (Rodø i Helgeland). 
Dette Expl. maa antages at have faaet disse af franske Fiskere under Island.

Under disse Vandringer kan den bevæge sig med betydelig

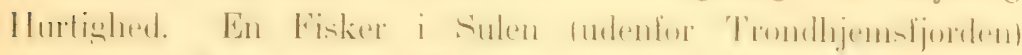

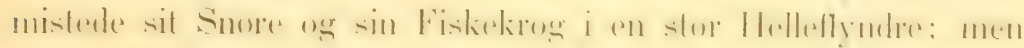

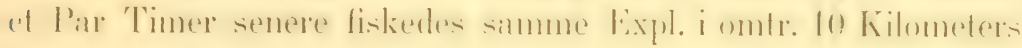
Afstand af en af hans Naboer, saaledes at Eieren inden Aften havde sit Redskab tilbage ${ }^{1}$.

Foden beslaar i Regelen af store Crustaceer, eller af Fiske. Af de sidste fortæres helst Smaatorsk, Brosme, Hyse, Uer

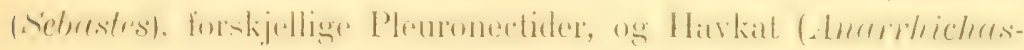
Arter); hos Exemplarer fra det grundere Vand findes ofte $C y$ -

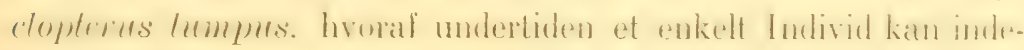
holde $6-8$ St.

I Ventrikelen af det ovenfor omtalte store Individ fra Lofoten, (hvis Vægt var 175 Kilogr.), fandtes 2 hele Exemplarer af Vinter-Torsken (Skrei).

Iovrigt er Foden ofte forskjellig i de forskjellige Aar. Sanledes fandt en Iagttager ${ }^{2} \mathrm{i}$ hele Aaret 1901 næsten udelukkende Lithodes maja hos Individer, langede udenfor Rodo i Helgeland.

Af lavere Dyr fortæres jevnlig Cephalopoder, ligesom lor-

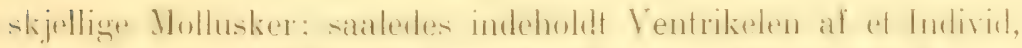

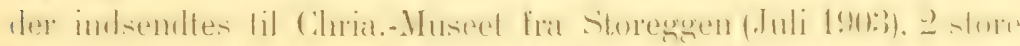

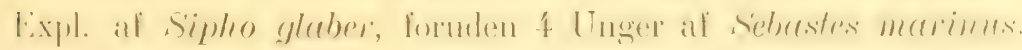

Hos 3 Unger fra Froien 20de Oct. 1903 (Totall. omkr. $430 \mathrm{~mm}$ ) var den fyldt alene med Crustaceer (Hyas, Inachus, Pandahrs, Munida).

Venstrevendt. Et Ex., fanget udenfor Aalesund omkr. 1S9S, (Totall. omkr. $300^{\mathrm{mm}}$ ), er venstrevendt (Chria.-Huseet).

Meddelt af Vareier Borthen ('Trondhjem).

2 E. Havno, Rodo, (Helgeland). Det samme er iagttaget ogsaa hos andre Fiske, sansom Sebastes, Gadus virens, og tildels hos 'T'orsken.

Vir.-Selsk, Forh. 1903. No. 9. 


\section{Roinhardtius hippoglossoides, (Walh.) 1792.}

Udbredelse. Sort-Kveiten er stationær, og paa flere - Seder rderst tatrig paa storre Dybder utenfor Finmarkens Kivter ${ }^{1}$; mod syd optreder den sand-ynligris paa alle passende Lrealiteter lings hele den Dylirands-Eg, som hegrandser Polarhassinet udenfor Nordlands Krster lige ned til Inoderne af Bergen, da den jevolig endnu erhodes af Fisker paa Storeggen udenfor Aalesund $\left.\left(62^{\circ} 63\right)^{\prime}\right)$.

Udenfor Finmarken ere firre sikre Localiteter kjendte, dia den som en paa disse Steder nasten viendilos Fisk sjelden af Fiskerne bringes tillands fra Bankerne.

Under et Besog paa Andena's (i Vesteraalen) (i Juli 1S!14). lindt jeg den her ligesaa talrig. som i Varangerfjorden, og den erholdtes multent daglig on Sommeren paa Pankerne. tildels i stort Antal, sammen med Anarh. Tatifroms ug M. berglan.

Endelig har den i de sidste Aar vist sig at bebo Bankerne udenfor Aatesumd. I Sept. LS96 modtog Bergens Museum el Ex. fra demene Loralited. hvor den angares af og til at erholder paia

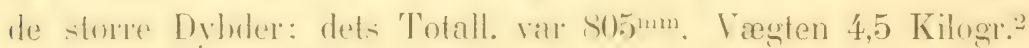

Shorrelser. Det mindste Expl., som jeg har undersogt fra din norske Kyst, havde en Totall. af $447^{\mathrm{mm}}$, og var fanget ved

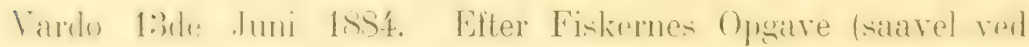
Vardo, -om wed. Indenies) kan den naa en Langde af over I Meter.

Udmaalinger. En Del Individer, afgivne i Aarenes Lob (i) Christimia-Mnseet fra Varangerfjorden. harde folgende Marl og Straaleantal:

2 Af en Bemærkuing af Leem fra 1767 fremgaar, at denne Art har været kjendt $i$ Varangerfjorden idetmindste fra Midten af hans Aarhundrede. "Ved Bug-Øen hos Rafte-Siden i Øst-Finmarken falder efter Beretning et ugemeent Slags af Helle-Flyndrer, hvilke ere de andre ulige paa Farven, saasom sorte over alt, saavel under Bugen som paa Ryggen; disse siges at overgaa hine i Fedme og Velsmagenhed." (Beskr. over Finmarkens Lapper, etc., p. 315. Kbhvn. 1767).

Berg. Mus. Aarbog 1898, No. III, p. 14. 


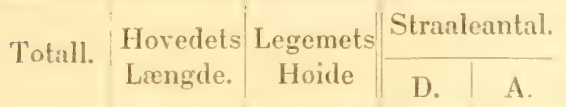

\begin{tabular}{|c|c|c|c|c|c|}
\hline $445^{\mathrm{mm}}$ & $104^{\mathrm{mm}}$ & $120 \mathrm{~mm}$ & 96 & 72 & Vadso 13de Juni 1884. \\
\hline $503^{\mathrm{mm}}$ & $132^{\mathrm{mm}}$ & $138^{\mathrm{mm}}$ & 96 & 73 & Vardo 14de Juni 1893. \\
\hline $90^{\mathrm{mm}}$ & $138 \mathrm{~mm}$ & - & SS & 66 & Vardo Juli 1891 (Han). \\
\hline $625^{\mathrm{mm}}$ & $145^{\mathrm{mm}}$ & $210^{\mathrm{mm}}$ & 90 & 73 & Vardo 14de Juni 1893. \\
\hline $650^{\mathrm{mm}}$ & $165^{\mathrm{mm}}$ & . & 99 & 76 & Vardo Aug. 1891 (Hun). \\
\hline (iti: $)^{111 \mathrm{~m}}$ & $(\tilde{5)} \cdot)^{m+1}$ & $1: 1)^{11,11}$ & 108 & 72 & 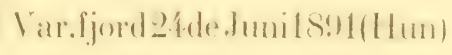 \\
\hline $70 \mathrm{~mm}$ & $176 \mathrm{~mm}$ & $210^{\mathrm{mm}}$ & 99 & 70 & Vardo 14de Juni 1893. \\
\hline $55^{\mathrm{mm}}$ & $168^{\mathrm{mm}}$ & & ? & ? & Vardo 14de Jumi 1893. \\
\hline
\end{tabular}

Levemaade. Sort-Kveiten, (som paa enkelte Steder kaldes Trold-Kiveite eller Gronlands-Kreite), har sit Tilhold paa de storm Dyblex, fra 100-500 Favne (1S0-910) Meter). eller derover: de fleste fanges pair en Dylude af mellem :300 og 400 Meter. Deni

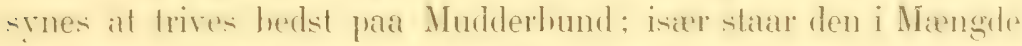
$i$ de store Fordyhninger mellem Fjeldgrundene. hoor Strmmen er svag, eller de samme "raadne Huller", hvori ogsaa Anarrhichas latifrons har sit Tilhold.

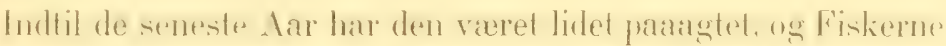

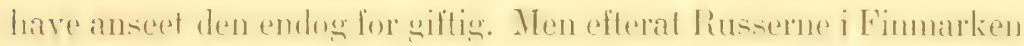

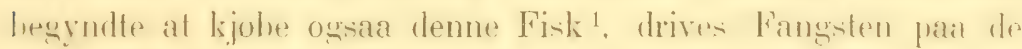
molite steder i stor Lidstrekning. og kan udenfor Vardo i e'llkelte Aar belobe sig til over 100,000 Stykker.

Den forekommer i disse dybe Huller i overordentlig stort Antal, og jevnlig kan et betydeligt Antal fanges paa samme Linesæt ${ }^{2}$. Saaledes er paa en enkelt 8-Aarers Baad i et af de sidste Aar taget $i$ et enkelt Dræt omtr. 6000 Kilogr. af denne Art.

1 Prisen er særdeles lav, for Tiden (1901) omtr. 17 Ore pr. Kilogr. (meddelt af Inspector Dahl).

2 I 1893, da Arten endnu var lidet paangtet, modtog Chria.-Ausect 6 St., alle fangede paa samme Dag (14de Juni) af en Fisker, som tilfieldigris var kommet til at stille sine Liner pai et stort Dyb. 
De kmmo vistmok erholdes lil alle Airstider, men det storste Fiske foregan i Vaamannederne, og det er sandsynligt, at en Cimandring fimber Sted efter Cigdetiden til de volre Banker $i$ I'olarhatred. Vind Virdo erholdes de fleste i Manederne Mai til August. men isier i Juni og Juli: til Agn benyttes Sild, Lodde. eller Blæksprut.

Som ovenfor nævnt, synes den at være ligesaa talrig paa Bankerne udenfor Andenes i Vesteraalen, som unlenfor Vardo. Inder "Michael Sars" (Mphold verl Andenes Sommeren 1901 sila Dr. Ifjort 2 Jaade optage ialt 40 St. (19) August) fra en

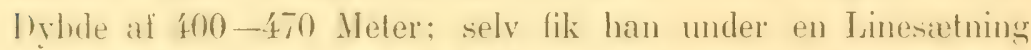
-imme Dag pata omtr. 914 Meters Dyb 13 St. af samme Art (foruden of Iatakjarringer, 16 Macrurns berglax, samt 2 Rokker, hvoraf den ene var Raja hyperborea).

Leilighedsvis gaar den ogsia, ligesom foregaamde Art. op

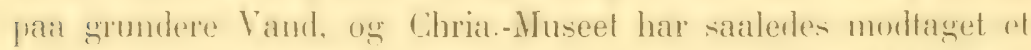
magl Expl., fanged med Lyster ved Vardso (1:3de Juni lisst), allsaa paa blot nogle faa Meters Dybde.

Forplantning. Rognen angives ved Vardo at være gydelierdig i sommermannederne; men intet er iovrigt kjendt on dens Forplantuing. Ungerne erholdes ikke af Fiskerne blandt de andre. Hos de af mig undersogte Individer. fangede ved Vardo eller Andenæs i Juni eller Juli, har Rognen endnu været fast og umoden. Hos en Hun, fanget ved Vardo i August (1891),

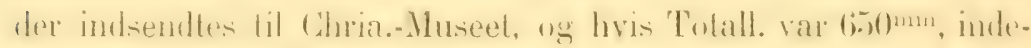

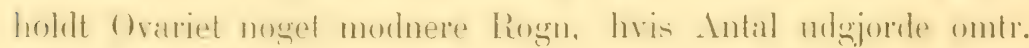
22,000 St. Aggets Diameter var ontr. $1,4 \mathrm{~mm}$.

II ipposlossoides platessoides, (Fahr.) 17,

Udbredelse. Gabe-Flyndre $n^{1}$ har af alle Landets Pleuro-

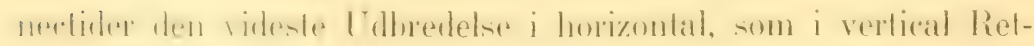
ning. Den er talrig overalt paa blod Bund saavel i Fjordene,

2 Arten har, (ligesom mange andre af vore Fiske), forskjellige locale Narne, ofte blot kijendte udenfor et lidet Omraade. 
som i Skjærgaarden, og saa langt ud fra Land, som der over-

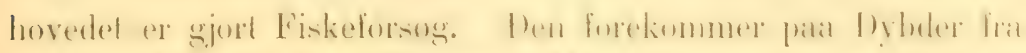

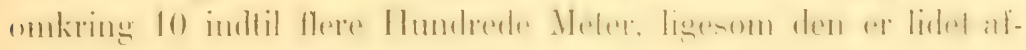
hængig af Bundtemperaturen, der kan vexle fra flere Grader over, til et Par Grader under 0 paa dens 'Tilholdssteder.

Den har især' sit 'Tilhold paa blod eller mudret Bund, og der kan

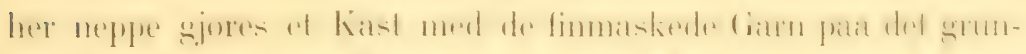

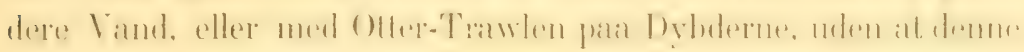
Art erholdes, underiden blot nogle enkelte, men ofte et stort Antal, og af vexlende Storrelse tira smaa Unger til de udvoxede Individer.

Saaledes optoges under "Michael Sar's'" 1ste 'Togt Sommeren 1900 i det indre af Porsangerfjord ${ }^{1}$ i et enkelt Kast 24 de

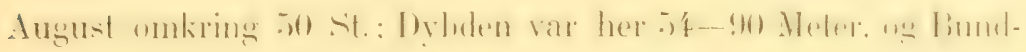
temperaturen $\div 1,2^{\circ}$.

Under Skibets 2det Togt Sommeren 1901 toges i 3 Træk i

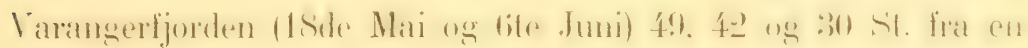

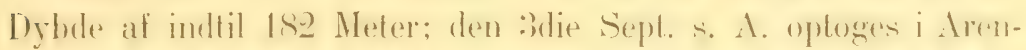

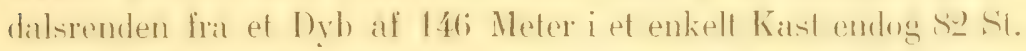

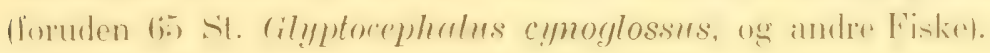

Vardilos. Denne Art er intetsteds Gjenstand for Fangst. I Finmandisfordene hiver den ofte hangende pata Linerme hlandt

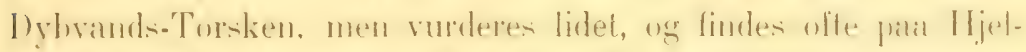

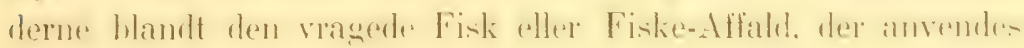
til Guano eller Kı'eaturforle.

Bothus rhombus, (Lin.) 1766.

Udbredelse. Slet.Hvarrens Udbredelse ved de norske Kyster kan endnu ikke angives med Sikkerhed.

I Christianiafjorden er den ikke sjelden, og et og andet Individ torvfores om Hosten i Christiania næsten daglig. Den er

2 Hjort, Fiskeri og Hvalfangst i det nordlige Norge (Aursheretn. vedlk. Norges Fiskerier 1902, 1 H. p. 18). Bergen 1902. 
fremdeles kjendt fra Stavangerfjordene; ligeledes er den fundet i enkelte Exmpliner red Bergen. Af disse sidste er et Expl. (i Bers. Nusenum) fanget i Mundingen af Sognefjorden; et andet modlon Bergens Biologiske Station fra statland i 1899. Dette H det mordliste P'uncl, hvor den hidtil med Vished er iagttaget, men sindsynligvis gan den mod Tord idemindste til Trondhjemsfjorden.

Et Ex. af en glat, venstrevendt Flyndre, fanget ved Rødo i Helgeland i 1902, tor saaledes have været denne Art ${ }^{1}$.

Hoirevendt. En Unge med en Totall. af $95 \mathrm{~mm}$, optagen af 1)r. Hjort red Sandesund i Christianiafjorden i Aug. 1897, ar høirevendt (Chria.-Museet).

Forplantning. Legetiden indtræffer hos os i Vaar-Maanederne, i liegelen i Mai. Ingel i Civelop-Stadiet er i -tort Antal optaget fra Vandskorpen ved Fspever (udenfor Stavanger) ite Juli 1873; hos de storste af disse (Totall. 20-28 $\mathrm{mm}$ ) var Oiet kommet helt orel pala (Hensiden. Lignende Yngel har jeg samlet fra Vamdskorpen ved Larkollen i Christianiafjorden lode Juli 1579: et Expl. med en Tolall. af $20^{\text {min }}$ var ligeledes nasten heli forvandlet.

Storrelse. De storste af mig under'sogte Expl. fra Norge havde en Tolall. af $525^{\mathrm{mm}}$ (Moss 4de Juni 1903), og 562mm (Tønsberg 23de April 1903).

Bothus maximus, (Lin.) 1766.

Nordgrondse. Pig.Hvarren har en vidtstrakt Udbredelse

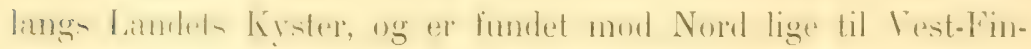

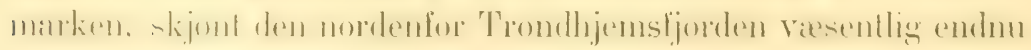
blot er kjendt gjennem spredte Individer.

: Meddelt af E. Hanno, Rodo. 
Udenfor Helgelands Kyster er den saaledes lundet hist og her, og ved Bodo er den neppe særdeles sjelden, men erholdes saagodtsom aarligt $\mathrm{i}$ et eller andet Individ; i Lobet al Vinteren 1897-98 bleve saaledes flere store Individer fangede ved Landegode. I Vesteraalen er et stort Ind. fanget 12te Mai 1S83, og indsendt til Chria.-Nuseet.

Endelig har Tromso Museum modtaget et Expl., langet ved Hasvik paa Soroen i $1889\left(70^{\circ} 28^{\prime}\right)$.

Forplantning. Legetiden indtrælfer i Mai, ligesom hos foregaaende Art. I April er Rognen endnu fast.

Det ovenfor omtalte store Exemplar fra Vesteraalen, fanget

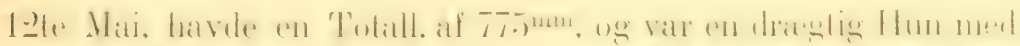

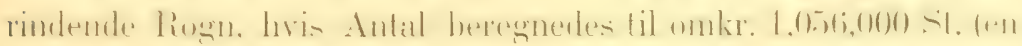
Del turde dog allerede have været gydt).

Yngel i Cyclop-Stadiet er optaget ved Vallo 2den Juli (1893),

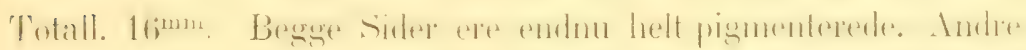
Yngel-Individer ere optagne, (i Selskab med foregaaende Arts Yngel), ved Espevær 5te Juli 1873 af Prof. Sars.

Ungerne kunne ogsaa efter Forvandlingen i nogen Tid fore et pelagisk Liv oppe i Vandskorpen. Under en Udflugt med Dr.

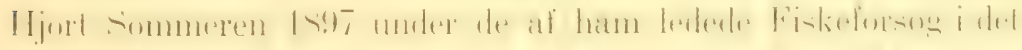

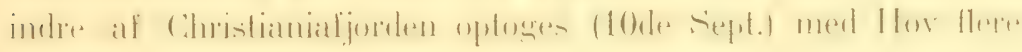
saadanne tommelange Unger, der oftest havde Tilhold under drivende Zoster $a$, og med stor Hurtighed svommede (med Oiensiden opad) hen under Vandfladen. De største af disse Unger havde en 'Totall. af $42 \mathrm{~mm}$; Blindsiden var' endnu forsynet med spredte brune Pigmentpuncter.

Storrelse. De storste Exemplarer, jeg hidtil har maalt fra Norge, havde en Totall. al $707^{\mathrm{mm}}$ (Moss, Christianiafjord 10de Juni 1903), og $775 \mathrm{~mm}$ (Bo i Vesteraalen 12te Mai 1853), og $790^{\mathrm{mm}}$ (Smolen 1Sie Oct. 1903). 
Varietet. Et Ind., der var forsynet med (svage) Bentorne ogsia pata Blimbiden, fandt jeg handt den Lorvforte Fisk fra Oerne i Christianiafjord 29de Mai 1891.

Hybrid (B. maximus + B. rhombus). Af den hybride form mellem I'ig-Ilvarren og Slet-ITraren, beskrevet af Malm i $157 \bar{i}$ moler Navn af Rhombus hybridus ${ }^{1}$, har Chria.-Nuseed gjomem Conserv. Hanson modtaget 2 bxpl., begge fangede i de -rmere Aar ved Sondre Sando, Hvaler (paa Grandsen af Bohuslen).

Af disse Exemplarer, hvoraf det største erholdtes 25de ().tober 18:2, det mindre den 7de Mai 189:3, var det storste Expl. luldt typisk, medens det mindre frembod enkelte Afvigelser. De havde folgende Maal og Straaleantal:

Totall. $285^{\mathrm{mm}}$. Hoide $157 \mathrm{~mm}$. Hovedets L. $80^{\mathrm{mm}}$. D. 67. A. 50. - 368 $\mathrm{mm}$ - $198^{\mathrm{mm}}$. - 103m: D. 67. A. 48.

Hos det mindste Expl. var der i Buen 4; skjel, i Resten af sidelinien omtr. 56 Skjoel, tilsanmen omtrent 99 Skjæel. Dog ex skjiellenes Begrandsning saa utydelig. at Antallet blot tilner'melsesvis kan angives.

Det sidsturevnte Exemplar synes at forbinde i sine Chama-

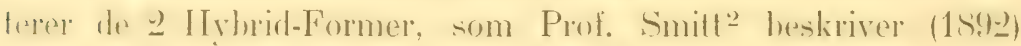
under Navnene Bothus maximus hybridus, og Bothus wombus hylurilus. Straaleantallet ligger saaledes omtrent midt mellem begge Formers; med den forstnervate Jybrid har den fielles Tormevolnding og Farver, og straalernes ringe Klowning; med den sidstnevente Form halr den naxmest farles de relative Legemsproputioner, idet Haleroden indeholdes i Lexemets storste Hoide nmtr. il:3 limge. Sideliniens Bue er ligeledes lang og lav, som lon denne -idste Iybridform, idet Perpendicularen indeholdes 2.5 Gange i Buens rette Grundlinie.

2 Götebb. och Bohuslïns Fauna, p. 511 (Göteb. 1877).

2 Smitt, Skandinaviens Fiskar, 2dra Uppl. 1, p. 441-445 (Stockh. 1S92). 
Lepidorhombus whilf-jagonis, 11 alh.) 17!!n!

Udbredelse. 'Tilhorer alene Landets sydvestlige Kyster, og

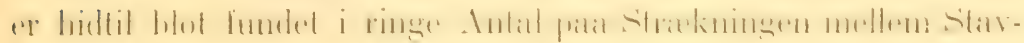
anger og 'Trondhjemstjorden.

I Skagerrak synes den ikke at forekomme, og intet Individ

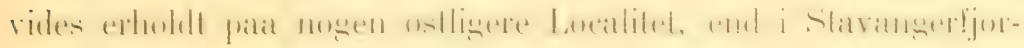
dene, hvorfra Exemplarer opbevares i Museerne i Stavanger og Christiania (sidste Gang indsendt 27de Juni 1901).

Hyppigst synes den at forekomme udenfor Bergenskysten, og den bringes aarligt i et eller andet Ind. tiltorvs i Bergen, hvor den kaldes Glas-Flyndre, eller Sjaa-Flyndre.

Fra Sondmor-Kysten er den beskreven allerede af Strom i

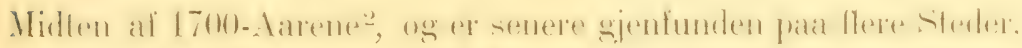
isier udenfor Chrisliansund: i 'l'rondhjemstjorden hler den fumbel

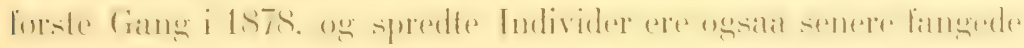
i denne Fjord. $\left(63^{\circ} 40^{\prime}\right.$ N. B.). Ved Nordlands Kyster er den hidtil ikke paavist.

\section{Udmaalinger.}

Totall. | Hovedets L. Hoide.

\begin{tabular}{l|r|r|r}
$165^{\mathrm{mm}}$ & $45^{\mathrm{mm}}$ & $45^{\mathrm{mm}}$ & Herlofjord Juli 1898. \\
$234^{\mathrm{mm}}$ & $61^{\mathrm{mm}}$ & $69^{\mathrm{mm}}$ & Herlofjord Juli 1S98. \\
$490^{\mathrm{mm}}$ & $122^{\mathrm{mm}}$ & $163^{\mathrm{mm}}$ & Bergen 1ste Sept. 1SS7.
\end{tabular}

Fode. Hos de af mig undersogte (yngre) Exemplarer tra

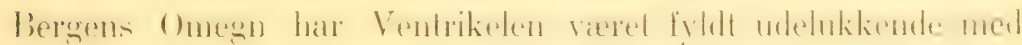
Levninger af Fiske. Hos et stort Ind. fra 'I'rondhjemstjorden

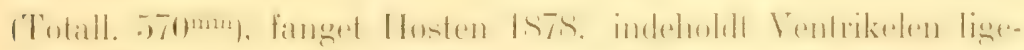

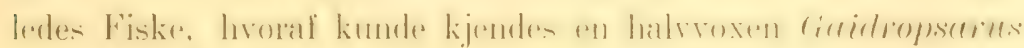
cimbrius ('Totall. $185^{\mathrm{mm}}$ ).

L. megastoma, (Don.) 1808.

2 "Annotations-Bog over forelaldende Merkwerdigheder i Natur-Historien paa Syndmor" (2 Dele, 1756-1780). Manuscript, opbevaret paa Universitets.Bibliolheket i Christiania. 
Forplemenimy. Legetiden synes at indrefle hos os i Vaareller. sommermantederne, men sikre Tagttagelser heron foreligge amdnu ikke. I 1844 meddelte Dühen og Koren, at de ved Berwen havile fatet et Individ med ikke fuldt moden Rogn i April.

lin Inge i Chria.-Nuseet, fanget red Bergen :3die Juni 1S:17 fiat en Dylude af omtr. 130 Meter, har en 'Totall. af $145 \mathrm{~mm}$, og er sandsynligvis omtrent 1 Aar gammel.

Farve. Hos de fleste Exemplarer danne de brunsorte Meleringer pait Legemets Oiensille 2_:3 tydelige Ringe paa Partiet indenfor interspinalhenene; lignende ringformige Pletter, men mindre. findes paa Bugen under Sidelinien udenfor Pertoralens Spidse.

Scophthalmus norvegicus, (Günth.) 1862.

Udbredelse. Denne Art (Smaa-Hvar) har en vid Udbredelse ved de norke Kyster, og forekommer mod Nord lige up i Finmarken, men overalt (som det synes) i ringe Antal.

I Christianiafjorden er den ikke sjelden, og jeg har aarligt mon Itusten kumnet udtage Exemplarer blandt de Smatisk. sum torvfores i Christiania fra Fjordens inderste Dele.

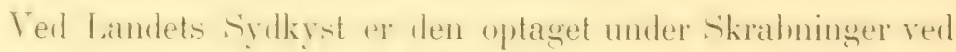
Miredo udentor Arendal i Aug. 185., ligesom flere Exemplarer

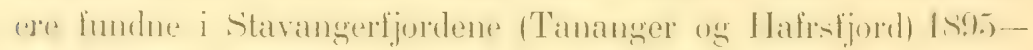
1898, samt ved Kopervik i Buknfjord i Juli 1881.

Far bergenskysten are Exemplarer, optagne ndenfor Bergen,

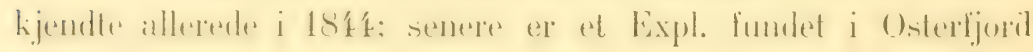
1895.

Mellem Bergen og Nordland er den fundet i Hevnefjord,

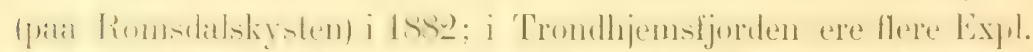

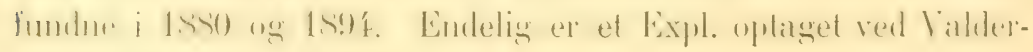
sund (Fosen) i Aug. 1884.

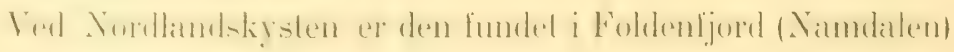
i Juli 1875, samt ved Bodo i 1874 .

Endelig er et Expl. kjendt fra Porsangerfjord i Vest-Finmarken. Dette Expl., hvis Totall. var $64^{\mathrm{mm}}$, blev optaget fra en 


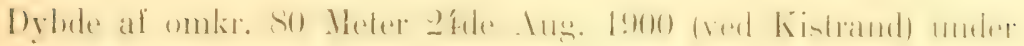
„Michael Sar's'، 1 ste 'Togt. $\left(70^{\circ} 25^{\prime}\right.$ N. B.).

Storrelse. Det storste af mig hidtil undersogte Individ har havt en Totall. af $98^{\mathrm{mm}}$ (Chr. fjord 16de Oct. 1903).

Farve. 'Til de foreliggende Beskrivelser af denne Arts Farvetegning kan foies, at hos enkelte Individer (Hanner) er Blindsiden ikke helt hvid, men langs Grunden af Dorsalen og

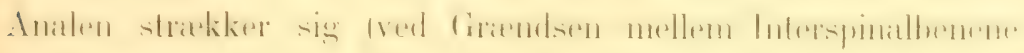
og Straalernes Rod) en Rrkke af 4 brunsorte Pletter, hvoraf de 3 bagerste staa indbyrdes noget trottere, end Afstanden mellem de 2 forste.

Forplantning. Gydetiden indtræffer ved Landets sydlige Kyster i Sommermaanederne. Den mindste Unge, der ophevares i Chria.-Nuseet, har en Totall. af 12,8mm, og er optaget i Christianiafjordens Munding i Aug. 1875. Denne Unge, der i en

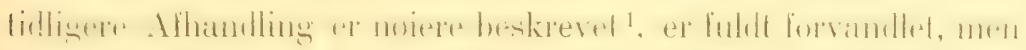
endnu uden Skjæl, og sandsynligvis udklækket $i$ Juni.

Et Individ, optaget ved Kopervik (Buknfjord) i Juli 1851 ('Totall. $88^{\mathrm{mm}}$ ), var en Hun, hvis Rogn syntes endnu ikke helt gydefærdig.

Flere Unger foreligge med en Totall. af $23-30 \mathrm{~mm}$, fundne i Juli og August; disse maa antages at være et Par Naaneder gamle.

Foden bestaar af Bunddyr, især Crustaceer, Annelider, og Unger af Bundfiske.

I det ovenfor omtalte udvoxede Ind. fri Christianiafjorden

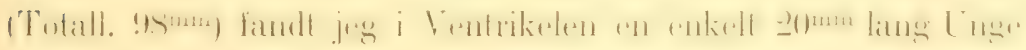

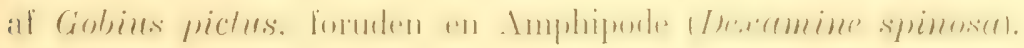

Forh. Vid. Selsk. Chria. 1879, No. 1, p. 77. Senere afbildet af Dr. Petersen i Beretn. fra den Danske Biologiske Station. VI, 1893, Pl. I-II, Fig. 16 (Kbhvn, 1894). 
I andre Exemlparer fra Christianiafjoden har jeg fundet Annelider (Polynomi): ot Expl. fra Hafrefjord (sondenfor Stavanger) indeholdt Dele af Mysider.

Zeugopterus punctatus, (Bloch) 1787.

Udbredelse. Haar-Flyndren tilhorer Norges Syd-og sydrestliyst, oge or udhredt fra Bohushen op idetmundste til Polarcirkelen.

Den forekommer overalt i forholdsvis ringe Antal. I Chri- liania og de andre Byer ved Christianiafjorden torvfores den log ikke ganske sjeldent, isar om Husten, og jeg har undertiden kunnel udtage et Par Stykker samme Dag blandt den sumafisk. der langes i Garn paa det grundere V'and i C'hristimiafjorden.

I samme Antal træffes den spredt rundt de ovrige Dele af de srdvestlige Krister. I Trondhjemsfjorden er den saaledes ingrinlunde solden, og Dr. Dihl har under sine Fiskeforsug i ls!s kummet optage et halvt Dusin Individer i Aalevad i forskjellige Dele af denne Fjord.

Nordligst er Arten fundel red Valdersund on Apelvar (paa (iramden af Helgeland) i 18st. samt ved Bodo, hror et YngelIndivid optoges under Bundskrahning af Prof. Sars i Aug. 1Ssi $\left(67^{\circ} 20^{\circ}\right.$ N. B. $)$.

Foryluntuim. Civdelerdige Exemplarer have hos os vared fundne i Mai og Juni. Lit sadant, langet She Mai 1900 (ved Christiansund). harde (Trarierne udspeentte af nasten modne Rogn: hos andre Exemplarer, fangede i Juni, har denne ræret

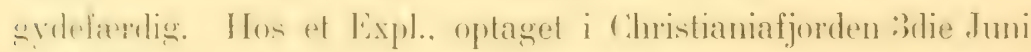

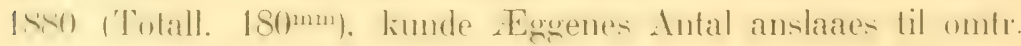
38,000 Stykker.

Unger. Den ovennæunte spæde Unge, optaget ved Bodo i Aug. 1887, havde en Totall. af $13^{\mathrm{mm}}$, men var allerede helt for-

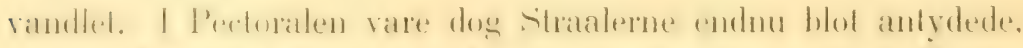

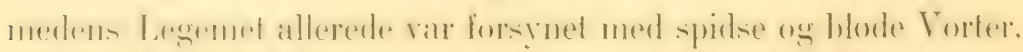


i Lighed med de reldre Individers. Farven er noget afvigende fra disses, idet venstre Side var tegnet med store, rundagtige morke Pletter, der ere jevnt udbredte overalt, ogsaa paa Hovedet og Finnerne ${ }^{1}$.

\section{Arnoglossus laterna, (Walb.) 1792.}

Uabredelse. Af denne Art er hidtil fundet (undersogt) omkl.

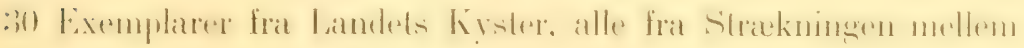
Christianiafjorden og Stavanger.

Det overveiende Antal af disse ere fangede i Christiania-

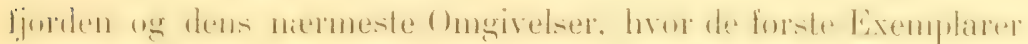

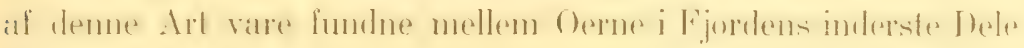
i Mai og Juni 1863.

Siden Begyndelsen af Sytti-Aarene, da en mere regelmæssig

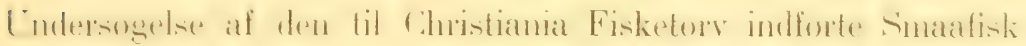

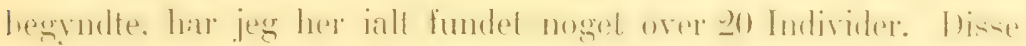
have alle varet oplagne i forskjellige Dele af Christianiafordent. hvor den synes at forekomme paa de fleste Localiteter lige op mellem Gerne udenfor Christiania. Enkelte Individer ere lige-

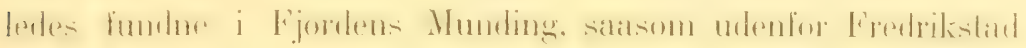
og ved Hvaler.

I de seneste Aar (1897-9S) ere fremdeles enkelte Individer

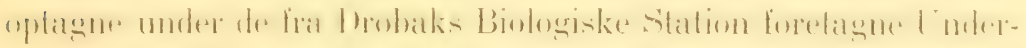
sogelser af Fjorden og den nærmest liggende Del af Kysten, saasom ved Aasgaardstrand og i Langesundsfjorden.

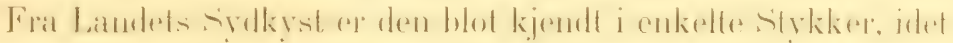
et yngre Individ optoges under Skrabninger af Prof. Sars ved Mærdo udenfor Arendal i Aug. 1885 (Totall. 112mm), ligesom ved Stavangerkysten 3 yngre Individer ere optagne under Dr. Hjorts Fiske-Forsog ved T'ananger 6te Aug. 1898.

Udenfor de ovennæunte 'Tilfæelde vides den hidtil ikke erholdt, men det er sandsynligt, at den er udbredt paa alle gun-

Individet er noiere beskrevet og afhildet (i 1893) af Dr. Petersen, (Beretn. fra den Danske Biol. Stat. IV, 1893, Fig. 15, p. 135. Kbhvn. 1891). 
stige Lomaliteler red Landets sydlige Kivster, om end i forholdsvis ringe Antal.

Stomelse. Det storste Ind., jeg hidtil har undersogt af denne

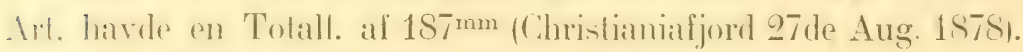

Legrmshoide. Af de tidligere meddelte Udmaalinger ${ }^{1}$ af demme Art vil fremgan, at Legemsforholdene re ikke helt ronslante hos ligestore Individer, og fornemmelig synes Legemets Hoide at kunne variere ikke ubetydeligt.

Silaledes havde af a nyligt erholdte (dragtige) Ung-Hururer fra Tananger, hvis Totallangde var noiagtig den samme hor herge. nemlig $110^{\mathrm{mm}}$. den ene en Legemshoide af $35^{\mathrm{mm}}$, den anden af $41 \mathrm{~mm}$.

Lemmunde. Deme Ant fanges i Tiegelen bot tillixldigl paa forholdswis ringe Dy (20-40 Meter) i de finmiskede Garn. dor kastes efter smansihl og anden Fjordfisk. Dog gaar den ogsa dyere. og tre fanget para en Drble af 100 Meter. Den er ikke synderlig lijendt eller paragted af Fiskerne, og hringes sjelden tillands, men udkastes handt Affaldet efter Garntrakningen.

Fomplamlming. I Ghristianiafjorden have Ifunnerne vitret rognfyldt i Mandederne Juni-.Juli: men endnu i August findes Hunner, der endnu ikke have kastet sin Rogn.

sataledes optoges ved Tananger af Dr. IJjort den tite August

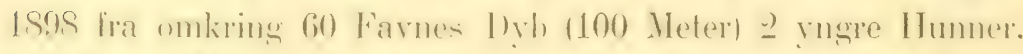
der begse have Ovarierne mdipandte af natsten moden liogn. Disse Individer havde en Totall. af $110 \mathrm{~mm}$.

Rognenes Antal hos et Par fuldt udvoxede Individer (Chri-

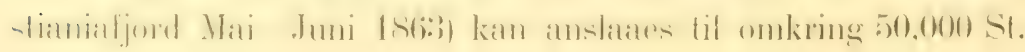

Unger. Chria.-Museet eier en spæd Unge med en 'Totall.

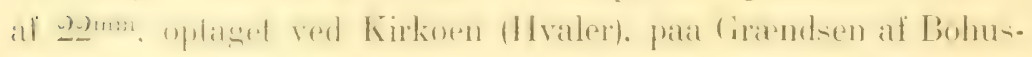
len i Aug. 1883. Delte Exemplar, der var i alle Henseender

I Forh. Vid. Selsk., Chria. 1879, No. 1, p. 79. 
udviklet som de udvoxede, og allerede var skjæilklædt, maa antages at have vreret et Par Maaneder gammelt ${ }^{1}$.

Fode. Hos de Expl, som jeg har kunnet undersoge af

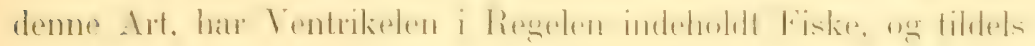
Crustaceer:

Hos Exemplarer fra Christianiafjorden have de kjendelige

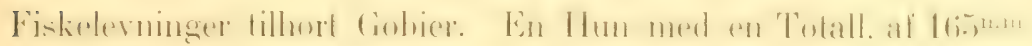
indeholdt en G. mimutus, omtr. $63^{\mathrm{mm}}$ lang: hos et andet Exemplar har jeg fundet Aphya mimuta, samt et Par Expl. af en Crangon.

Et Par Individer fra Tananger, optagne fra en Dybde af

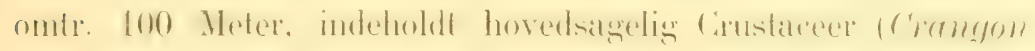
allmanni og Ampelisca typica), samt Dele af Fiske.

\section{Pleuronectes platessa, Lin. 1766.}

Storrelse. Det storste Ind. af Konge-Flynderen, som

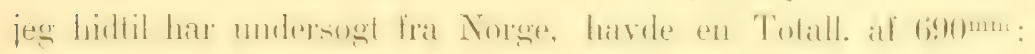
Hovedets L. var 180 $\mathrm{mm}$ (Trondhjemsfjorden 18de Oct. 1889). Ved Kysten af Nordland kunne Individerne naa en endnu be-

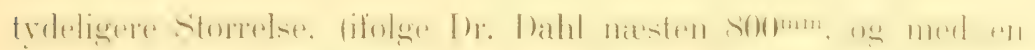
Vægt af næsten 4 Kilogr.).

Tillıoldssted. I Forhold til Landets enorme Kystlinie ere

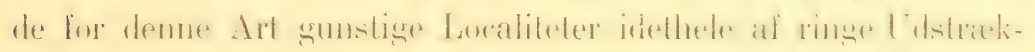
ning hos os. De aabne, sandige Kyster med svag Heldning mod Dybet, som betinger dens overordentlige store Antal ved

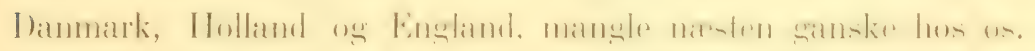
Dens 'Tilholdssted hos os bliver saaledes, som Dr. Hjort² har

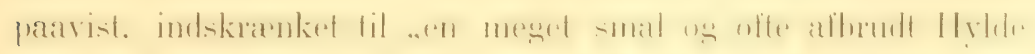
om Land og Øer, hvor til og med Bundens Beskaffenhed ofte

I Exemplaret er afbildet af Dr. Petersen i Beretn. fra Danske Biolog. Station, IV, 1893, Pl. I-II, Fig. 17 (Kibhvn. 1894).

2 Hjort og Dahl, Fiske-Forsog i norske Fjorde, p. 60 (Chria. 1899). 
kan Viere usumstig for Fisken. De wrumde Sandbugter og Strande. hor den smata lingel skal voxe op, er far og langt imellem, og de ligger kun sjelden aabne mod Havet."

Indivil-Antallet af denne Art maa sanledes idethele kaldes rulativt ringe hos as, summenlignet med de Masser, der forekomme ved Nordsoens vestlige og sydlige Kyster.

Forplantning. Den regulære Gydetid hos os er i Vaar.

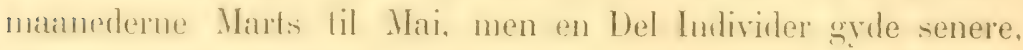
lige ud i Juni og Juli.

Paa Legepladsene synes Hannernes Antal at være storst. Sialches hive enkelte Fiskere iagttaget, at Ifunnen, der i Regelen er storre, end Hannerne, ofte kan være omgivet af $6-8$ Inanfis: borttages den store Hun, forsvinde llannerne snart fra stede!. molems alle dis-e kumne optages, uden at Hunnen forlader Gydepladsen.

Som ovenfor nærnt, maa Konge-Flynderens Gydepladse hos

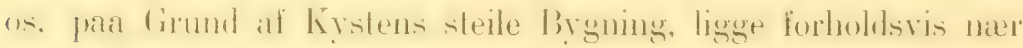
Jambl. Laat enkalte Steder ved Nordland. hror deme Art hidlil i kun ringre (rrad (eller ikke) har veret Gjenstand for Fiskeri, simbr de sydende Individer sig ofte $\mathrm{i}$ stort Antal paa enkelte crumber i lagetiden, og kmune her give Anledning til indhringende Fiskerier, de eneste Fiskerier af denne Art hos os, der we af monen stome Betydning. endskjont Fisken pata denne Tid er af forholdsvis ringe Værdi.

Eygene. Gjemem talrige L'ndersogelser ved Dammarks og andre vestenropieiske Kyster. hrille for rort Lands Vedliom-

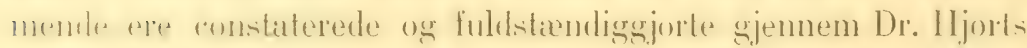

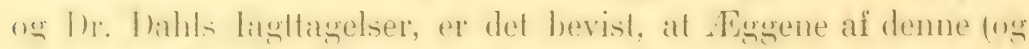

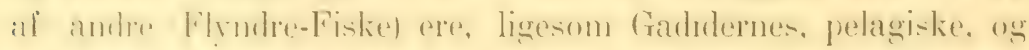

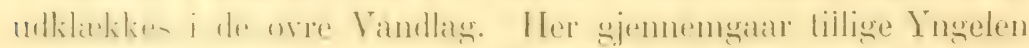
$\sin$ Larvetilstand, og forst naar Forvandlingen er fuldendt,

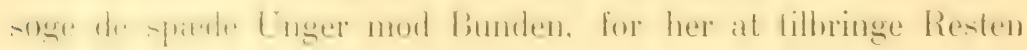
af sit Liv. 
Saasnart Aggene ere belrugtede, stige de derfor (hvor Salt-

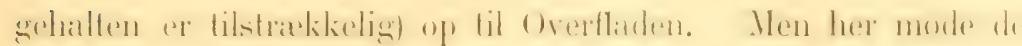

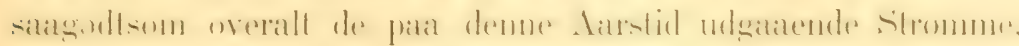
og det overveiende Antal $\mathrm{Eg}$ fores (sammen med alle andre dri-

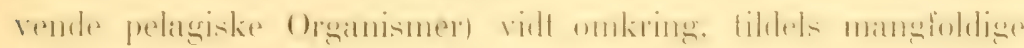
Mile fra Land, eller ud af Fjordene.

Under denne Drive-Periode foregaar Eggenes Udklækning,

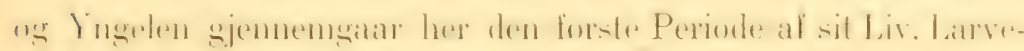

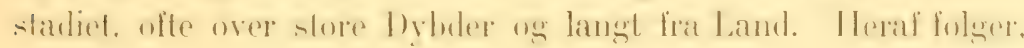
som Dr. Hjort har paavist, at kun et ringe Faatal af den for-

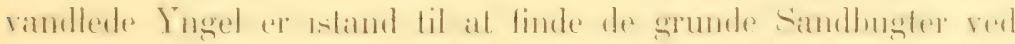
Stranden, der ere nodvendige for deres videre Udvikling, men Hovedmassen af de gydte Eg og Yngelen gaar tilgrunde.

Gydetiden strækker sig, som ovenfor nævnt, over et 'l'idsrum af flere Maaneder, og der erholdes ofte lugel i forvantlingsistadiet endum langt ud i Juli. Fu Del satulu lingel. optaget ved Vadsø (Finmarken) i Juli 1879, havde en 'Totall. af 10-12 ${ }^{m}$ : de vire endum nesten helt transparnte, og det venstre Die befandt sig nærved eller i Profillinien. Aggene, hvoraf disse vare udklækkede, have sandsynligvis været gydte i Juni (Chria.-Mus.).

Ogsaa i Christianiafjorden findes undertiden Yngel i Forvandlingsstudiet endnu i Juli; men de fleste Unger ere her paa denne Tid fuldt forvandlede, og have en Totall. af $15-20 \mathrm{~mm}$, eller derover.

Unger, der netop have tilendebragt Forvandlingen, har jeg

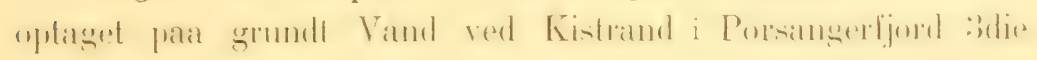
Tuli 1883. De mindste af disse havde en Totall. af blot $10^{\mathrm{mm}}$, og var saaledes endog mindre, end enkelte af de ovenfor om-

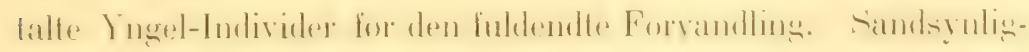
vis have disse været udklækkede $\mathrm{i}$.Juni, medens de storste al

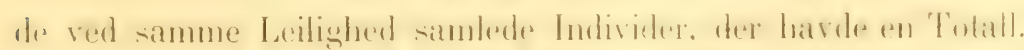
af $41^{\mathrm{mm}}$, maa antages at have været udklækkede $\mathrm{i}$ April eller Mai. 
Under "Michael Sars" 1ste Togt Sommeren 1900 toges ligeleder nelop) forvandlede Unger (Totall. 12-16 ${ }^{\mathrm{mm}}$ ) i Stranden

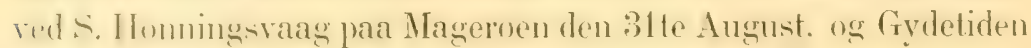
har her neppe været tidligere, end i Juli.

Ungerne holde til paa grund Sandbund, ofte umiddelhart oppe i Stranden. I Sammenligning med de enorme Masser af Unger af denne Art, som forekomme ved de ovrige vesteuropreiske Kyster, ere Norges Kyster relativt fattige paa Individer. ogsaa $\mathrm{i}$ denne Periode af Fiskens Liv.

Ungernes Fode synes hovedsagelig at bestan af littorale Crustaceer. Hos en Del Unger med en Totall. af omkr. $3.5^{\mathrm{mm}}$. uptagne ved Foldenfjord $\mathrm{i}$ Namdalen, vare Ventriklerne fyldte af Strand-Copepoder (Harpacticider).

Frrevariationen med helt eller delvis pigmenteret Blindside kan opstaa allerede hos Ungerne. Hos et Ind. i Chria.Museet, optaget red Moss i Juli 189?, hvis Totall. var $71^{m m}$, var hele Blindsidens bagre Ialvidel af samme Farve som Oiensidens.

Pleuronectes limanda, Lin. 1766.

Forplantuing. Fydetiden indtraffer hos Sand-Flyndren i Regelen i Maanederne Juni og Juli, sandoynligvis tildels i Mai. I Trondhjemsfjorden har Dr. Dahl udtaget og befrugtet Rogn i Midten af Juni, og faret Ungerne udliakkede faa Dage senere.

Inger. Af derne Art eier Chria.-Alweet flere Unger, optagne fial forskjellige Dele af Kysten i Juli ong August Manneder. De

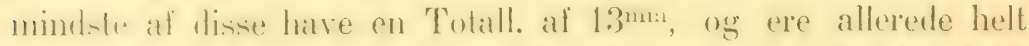
forvandlente: disie optoges udenfor Bodo fra en Pybde af :31;

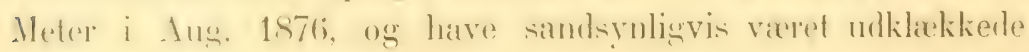
i Juli.

Amdre: Individer, der ligeledes vare eptagne udenfor Kysten

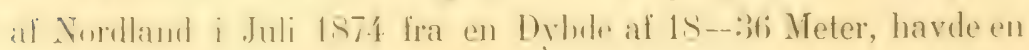


L. af $20-35^{\mathrm{mm}}$. Alle vare eiensynlig af Aarets Kuld, og udklækkede i Mai og Juni.

Et Yngel-Individ i Cyclop-Stadiet i Chria.-Museet, fanget i

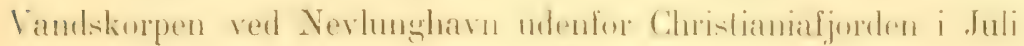
1875, synes at tilhore denne Art. Totall, er 9, $3^{\mathrm{mm}}$; det er endnu

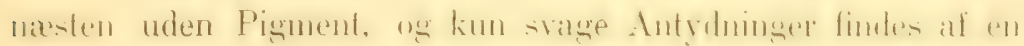

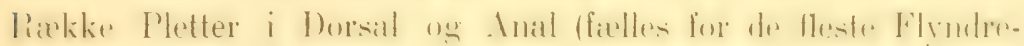
Arter's Yngel). Sidelinien er ikke ansat.

Ungernes Fode. De smaa Unger synes at have sit Tilhold paa et noget dybere Vand, end f. Ex. Ungerne af $P l$. platessa, og flere ere, som ovenfor næunt, optagne paa indtil

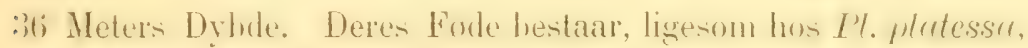
inere af smaa Crustarer. Hos de ovemavnte smat Unger meal

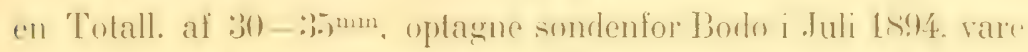

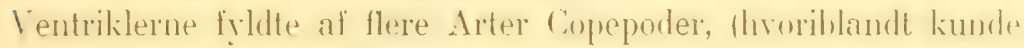
kjendes Longipedia coronata).

Hos de noget storre Individer ffra Christianiafjordent har jeg ligederles fumlet Crustaceer, satsom Pagurer. Disse lages i

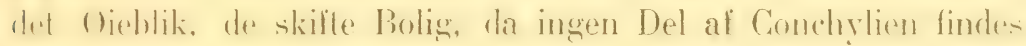
blandt Foden.

Pleuronectes flesus, Lin. 1776.

Forplantning. Skrubben gyder hos os saavel i Vaar-, som sommermantederme. Ilos el Individ at Middelatorrelore. fanged undenfor Christiania sde Marts, havde liognen alleredt.

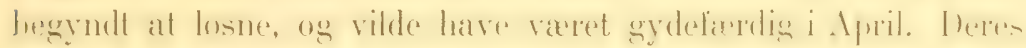
Antal hos dette Ind. anslog jeg til omtr. 413,000 St.

Gydefærdige Individer ere iøvrigt fundne (ved Landets sydlige Kyster) lige ud i Juli.

Eggene drive, som andre Flyndre- Eg, med Strommen i

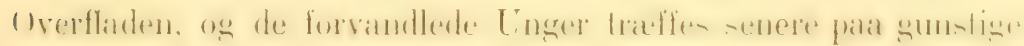
Steder i Stranden paa det grunde Vand, tildels i stort Antal.

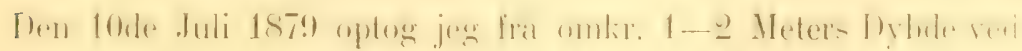

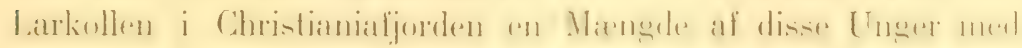
en Totall. af $30-40^{\mathrm{mm}}, \mathrm{og}$ alle bestaaende af Aarets Kuld. 
Unger af lignende Storrelse kunne om Sommeren optages vel de fleste sandede Strande satavel i Fordene, som ved Havet. Chria.- Muset eir saaledes Expl. med en Totall. af $36^{\mathrm{mm}}$, der (re tagne i Harkanlen ved IJvitingso i Mundingen al Buknfjord i Aug. 1872.

I Ferstwand. Et ikke ringe Antal af de smaa Unger, og sandsynligvis ogiaa de noget storre Indiviler, stige fra Elvemunllingrue op i Elvene, hvor lisse have gunstige Betingelser for deres Indvandring, og de kunne herunder trienge langt op, on ind i de lavereliggende Indsoer. En saadan Indvandring svnes; at finde. Sted i nesten alle nogenlunde sagteflydende Elve lang.s. Krysten, og Individerne nedsatte sig derefter for kortere eller liengere Tid i Elvene selv, eller i Tudsoerne, hvor de kunne træffes i alle Aldre fra tommelange Unger til Individer. Aer i Storrelse nærme sig de fuldt udvoxede i Havet.

Paa enkelte Steder kunne disse i Elvene indramberle Unger foreksmme i store Masser. Dr. Dahl traf dem saaledes i ()rklas nedre Luh, omtr. \& Kilem. fra Mundingen, den lode Mai 1894 i saa stort Antal, at han i hvert Træk med Aalevadet kunde trekke flepe Hundrede Stykker. Deres Langde varierede fra 45 til $130^{\mathrm{mm}}$; de fleste var $50-60^{\mathrm{mm}}$ lange $^{1}$.

Det er sandsinligh, at alle disse vare Unger fra foreganende Aar, selv de mindste; i. dette Tilfælde havde de allerede indvandret det foregaaende Aar, men Væxten $\mathrm{i}$ det ferske Vand kan have foregaaet langsommere, end i Havet.

De Individer, der forekomme i Elvene eller" Søerne, naa -jehlen nogen betylelig Storrelse. Chria.-1huseet eier et Exemphar hra Storevand i Hardanger, indsamlet af Prof. Sar's i Juli 1873 , hvis Totall. er $245^{\mathrm{mm}}$.

I enkelte af de storre Elve kunne de trænge op i en be-

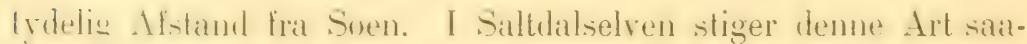
lerlen up h1 Drage. omkr. 55 Kiloneter fra Mundingen; i Orkr. dalselven gitar den op til Aarlivold, der ligger omtr. 20() Kilom.

1 Det Kgl. Norske Vid. Selsk. Skr. 189S. No. 10 p. 49, Appendix, p. XVIII ('Thjem 1897). 
fra Soen; i Tanaelven er den fundet idetmindste udenfor Mats-

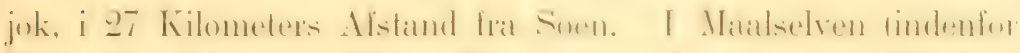

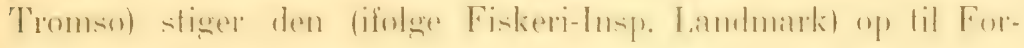
eningen af Maalselven og Bardo-Elven, eller til en Afstand fra Soen af lidt over 34 Kilom.

Den længste Afstand fra Soen naar den maaske i NamsenElv, hvor den stiger op idetmindste til Grong Kirkeplads, eller i en Afstand af omtr. 50 Kilom. fra Soen. De forekomme pan dette Sted endnu i temmelig stort Antal, og fiskes paa Krog: Størrelsen pleier at variere mellem 100 og $200^{\mathrm{mm}}$. Smaa Unger ere ikke med Sikkerhed bemarkerle her.

Sikre Iagttagelser om, hvor længe den kan opholde sig i det ublandede Ferskvand, eller on den her er istand til at forplante sig, foreligge endnu ikke. Det sandsynlige er, at alle Individer, fra de storste til de mindste, ere indvandrede, $o g$ at nogen Forplantning her ikke kan finde Sted ${ }^{1}$.

Fode. Ungernes Fode i Stranden bestaar, som hos andre

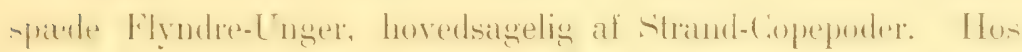
en Del Unger med en Totall. af omkr. $35^{\mathrm{mm}}$ (Larkollen 10de Juli 1879) vare Ventriklerne fyldte af Harpacticider (Idya).

Ferskvands-Individemes Føde bestaar af allehaande Dyr fra Bunden, især Insecter, samt Fiske-Unger. Hos en Unge med en 'Totall. af 58m, sum jeg optog paa grundt Vand i Drammenselven i Juli 1880, omtr. 8 Kilom. fra Mundingen, fandtes et halvt Dusin Yngel af en Leuciscus-Art, samt Larver af

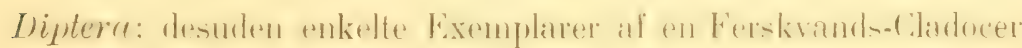
(Alona affinis).?

Hos det ovenfor nævnte nær udvoxede Exemplar fra Storevand i Hardanger (Juli 1873) fandtes knuste Skaller af Ferskvandssnegle, et Par Larver af Odonater, samt 4 Expl. af en

1 I "Norges Fiske". (Tillagsh, til Forh. Vid. Selsk, Chria. 1874) p. 146, har jeg fremsat den Formodning, at de smaa Unger, som ofte treftes i Ferskvandene, vare udklakkede lier, en Antagelse, som hidtil ikke er bekreltet. 
Coleopter, der viste sig at være en i Norge hidtil blot ved Christiania funden Art, Deronectes 12-pustulatus. ${ }^{1}$

(ynicoglossus microcephalus, (Don.) 1802.

Shorrelse. Det storste Expll, jeg har undersogt fra Norge. (fanged ved Bergen בfide Juni 1899), havde en Totall. af $4.355^{\mathrm{mm}}$. Den henevnes i Bergen Lomra, i Christianiafjorden .IL r iTunge, eller Berg-Flyndre, i Trondhjem Mari-Flyndre.

Unger. Et Par Unger, optagne af Prof. Sars udenfor Vadsø (Varangerljortent i Aug. 1874, ere 36 4-2nu lange. Disse ere nærmere beskrevne i "Norges Fiske" (p. 145), og ere de eneste silire Unger al deme Art, som jeg hidtil har kunnet undersoge. De mata ankages at have tilhort Aarets Yngel, og at have veret udklækkede i Mai eller Juni.

Fode. De ovennævnte Ungers Ventrikel indeholdt mange Eximplarer af den par moderate Dybder overalt talrige Copespode Idya furcata.

De seldre leve af forskjellige Slags Bunddyr. I Ventr. af et Expl., langel ved (1)kedalsoren itte Mai Ls!!?, har Dr. Dahl fundert sman Actinier.

Varietet. Chria.-Museet har modtaget et Expl., fanget uden-

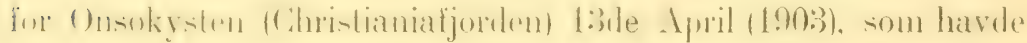
Hovedets forreste Del, hele den ydre Rand af Dorsal og Anal

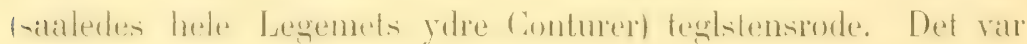
en Hun, fyldt med umoden Rogn.

Glyptocephalus cynoglossus, (Lin.) 1766.

Udbredelse. Denne Art (Hunde-T'Inge) hører til de ved

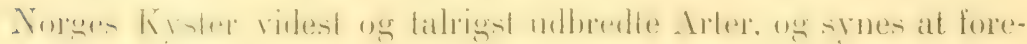
komme overalt paa det noget dybere Vand, hvor Bunden er ler-

1 Bestemt af Conserv. Strand. 
holdig. I Fjordene trange de ind lige til disses Bund, og de

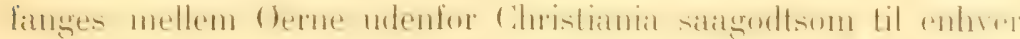
Aarstid; de synes at være $\mathrm{i}$ hoi Grad stationære, og paa alle

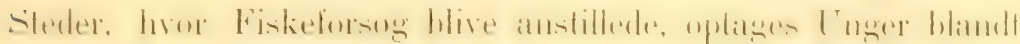
de gamle i samme 'Trrk.

Paa gunstige Localiteter synes de at forekomme samlede $\mathrm{i}$ stort Antal. I Arendalsrenden kunde saaledes "Michael Sars" i Beg. af Sept. 1901 optage mellem 50-100 St. i samme Kast med Otter-Trawlen; Dybden var her 300-500 Meter.

Unger. De mindste Unger af denne Art i Chria.-Museel have en 'Totall. af $46^{\mathrm{mm}}$ og $65^{\mathrm{mm}}$, og ere optagne paa en Dybde af $164 \mathrm{og} 270$ Meter ved Florø i Juli 1873. De ere i dette

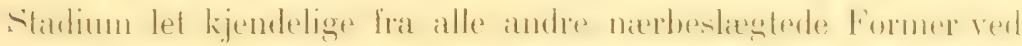

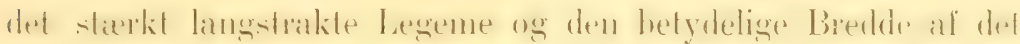
af Interspinallnenene optagne limm, i forthindelse med dettemærkelige 'Transparents.

Allerede hos det mindste af disse Unger var Artens characbriskike Farvelegnimg liktede. Interspinalstyket havde paia

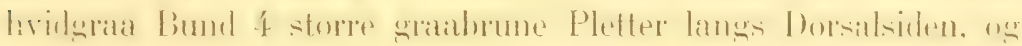
3 langs Ventralsiden, foruden 1 Plet tvers over Caudalens Rod.

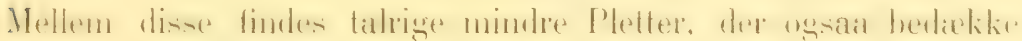
Finnerne. Oiensidens Pectoral har allerede faat sin sorte Farve.

Disse regelmæssige Rækker al Pletter, der bibeholdes hos

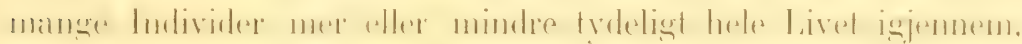
synes dog ofte helt at mangle ogsaa hos Ungerne, og et stort

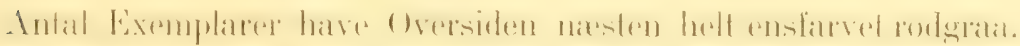
En Del noget storre Unger, med en Totall. af $70-80^{\mathrm{mm}}$, optagne i Langesundsfjord 29de Sept. 1898, vare saaledes oventil ensfarvede, men harde alle henimod Spidsen af Caudalen Spor af et dybsort 'T'verband (ligesom Pectoralens Spidse).

Ungernes Fode. Hos de ovenfor omtalte Unger fra Lange-

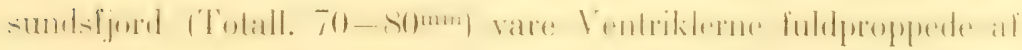
smaa Crustaceer, nemlig at Isopoder en Leptognasia, af Cuma-

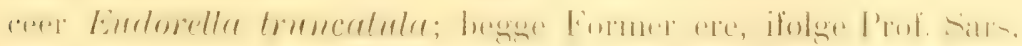
væsentlig knyttede til Lerbund. 


\section{Fam. Soleidae.}

Solea solea, (Lin.) 1766.

Uabredelse. 'T'ungens Udbredelse ved de norske Kyster' kim mulnu ikke med sikkerhed angives. Den forekonmer idethele i mindre Antil. og er endnu bot kjendi fra et ringe Antial Localiteter.

I Christianiafjorden synes den at viere mindst faratallig, og den kin om sommeren og Hosten nasten daglig sees $i$ et ellem amlet Lxemplar pai Fisketorvet i Christiania: men heller ikke her langes den uden enkeltris, eller i faa lixemplarer sammen.

Fra Stavangeregnen el den ligeledes kjendt som en idet. hele sparsonit forekommende Art, men erholdes dog fra og til udenfor Jæderen og i Fjordene omkring Stavanger.

Ved Bergen angives et Expl., (der dog ikke er blevet opbe-

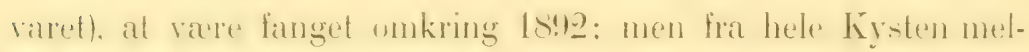
lem Fergen og Varangerfjorden mangler hidtil enhwer sikker Tagttagelse om denne Art ${ }^{1}$.

Storrelse. Et Hun-Ind. med flydende Rogn, fanget ved suon i Christianiafjorden 14te Juni $189 \%$, havde en Totall. af

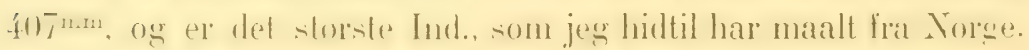

Forplentuing. Rognfyldte Individer har jeg andigt fundet

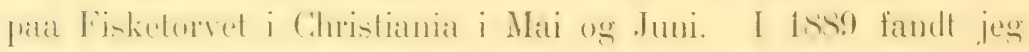
her et næsten gydefærdigt Exemplar allerede den 1ste Mai.

Unger. Den mindste Unge, som vides iagttaget i Norge, havde en 'Totall. af $8 \mathrm{~mm}$, og var, (som i Noten omtalt), angivelig

Det var derfor helt uventet, at et Glas med Yngel-Individer af forskjel. lige Pleuronectider, optagne af Prof. Sars udenfor Vadso (i Varangerfjorden) i Juli 1879, og af ham afgivet til Chria.-Museet, indeholdt et enkelt, netop forvandlet Individ af denne Art. Dets Totall. var $8 \mathrm{~mm}$.

Forsavidt ingen Forvexling af Localiteten her har fundet Sted, kan det derfor neppe betvives, at Solea efterhaunden vil blive paavist ogsia pai andre Puncter ved vore nordlige Kyster. 
1903.] MEDDELELSER OM NORGES FISKE I AARENE 1884-1901. 105

optaget af Vandskorpen (blandt Yngel af $P l$. platessa) ved Vadso af Prof. Sars i Juli 1879. Dette Ind. var allerede fuldt forvandlet.

Andre smaa Unger med en 'Totall. af $14-32 \mathrm{~mm}$ ere lundne

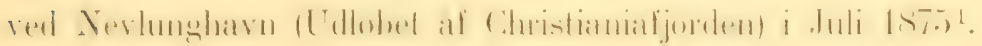

Solea lutea, (Risso) 1810.

Ny for Noryes Fanna. Et ungt Individ, af denne Art el

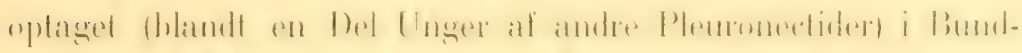

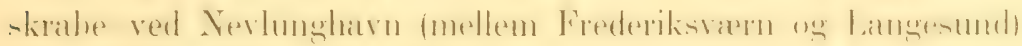
i Juli 1875 af Prof. Sars.

Dette Ind. er, tilligened de ovrige paa samme Localitet op-

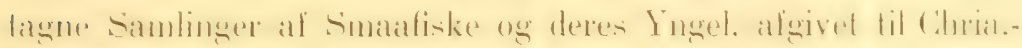
Nuseet, og har en 'Totall. af $22 \mathrm{~mm}$. Det er nærmere omtalt i "Archiv for Math. og Naturv." B. 23, No. 7, p. 11. (Chria. $1901)$.

Uagtet sin ringe Storrelse er Artens Characterer vel udprægerle. Blindsilens l'ectoral mangler; Mundspalten narr til Forranden af det nederste Oie; Pectoralens ovre Straale er hvid.

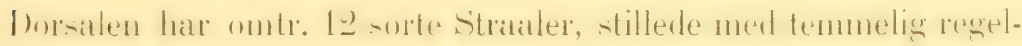
mæssige Mellemrum.

Da denne Art neppe kan antages at foretage lange Vandringer, er det sandsynligt, at den, skjont senere intet Ind. er

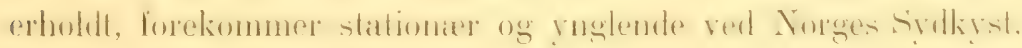
on end i ringe Antal.

\section{Fam. Sternoptychidae.}

Argyropelecus elfersii, (Guv.) 1829.

Udbredelse. Af denne Art er i Aarenes Lob omtr. et Snes

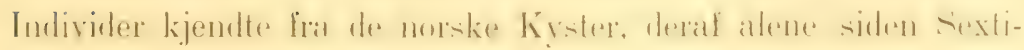
Aarene 12 Individer.

1 Disse ere alle narmere lueskrevne i Forh. Vid. Selsk. Chria. 1879, No. 1, p. 8:. 
Disice ere alle nataede under Land paa Strakningen mellem Bersen og Norkap. Sondenfor Bergen vides intet Individ med Sikkerhed hemarket. De fleste Exemplarer ere fundne udenfor Bermensisisten. hror der enkelte Aar har veret iagttaget flere Individer. dels opkistede paa Stranden, dels udtagne af Ventriklerne af Torsk og Sej.

Fremdeles have enkelte Individer fundet $\sin$ Vei helt ind $\mathrm{i}$ Tromdhjemstjorden. Fra Nordlands Kyster foreligge flere Stykkerr; men da sjeldent furekommende Former idethele hlot leilighedsvis blive omtalte eller opherarede paa denne lange Kyststrakning. man det antages, at el ulige storre Antal $i$ Aarenes Lob i Virkeligheden ere havnede paa denne Del af Kysten.

Fremdeles enkelte Individer fundne udenfor Krsterne af Tromso Amt: endelig er 1 Ind., det nordligste af alle, strandet

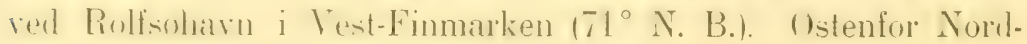
cap er Arten hidtil ikke paavist.

De Individer, der vides at have været opbevarede, ere folgende. ${ }^{1}$

\section{Bergens-Kysten.}

Bougestrommen, Bergen . . 10de Marts 1849. Totall. 68mm Glesvær, Bergen ..... 15de Mai 1849. Totall. $76^{\mathrm{mm}}$ Glesver, Bergen . . . . 15de Mai 1849. Totall. $66^{\mathrm{mm}}$ Glesvær, Bergen . . . . . ult. Marts 1865. Totall. $67 \mathrm{~mm}$ Glesvær, Bergen . . . . u ult. Narts 1865. Totall. $81^{\mathrm{mm}}$ Dalsfjorden, Sondfjord ..... April 1874. Totall. $75^{\mathrm{mm}}$ Bergensfjord . . . . . 26de Mai 1876. Totall. $80^{\mathrm{mm}}$ Hegholmen, Bergen ... . 28de Jan. 1890. Totall, 69mm

\section{Trondhjems-Kysten.}

Bjugn, 'Trondhjemsfjord . . . . Nov, 1879. Totall. $79^{\mathrm{mm}}$

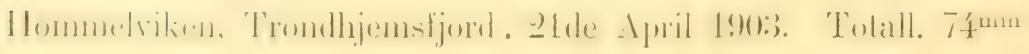

1 For Tiden (1903) oplevares i de norske Museer 15 Exemplarer af denne Art, (7 Expl. i Chria.-Museet, 4 Expl. i Bergens Mus., 2 i Trondhjems Mus., og 2 i Tromso Mus.). 


\section{Nordlands-Kysten.}

Ranen, Helgeland .... 16de Marts 1835. Tatall. $70^{\mathrm{mm}}$ Nordland ....... Tredive-Aarene

Hvalvar, Rodo..... Vinteren 18S1-82

Lovunden, Helgeland . . . 30te Dec. 1897. Totall. 64mm Rodø, Helgeland . . . . . Gte Febr. 1903. Tolall. 94

Tromso-Kysten.

Tronnsi-Kisten. . . . . . . NST

Dverberg, Andøen . . . . Hosten 1885. Totall. 84 $4^{\mathrm{mm}}$ Tromsosund ....... Iste Marts 1898. Totall. $50 \mathrm{~mm}$

Vest-Fimmarken.

Rolfso........ 15de Jan. 1882. Totall. $66^{\mathrm{mm}}$

Storrelse. Det mindste af de hos os hidtil fundne Exemplarer havde en Totall. af omtr. $50 \mathrm{~mm}$. Dette fandtes opkastet paa Stranden i torret og noget defect Tilstand i Tromsosund Iste Marts 189S. De største Exemplarer havde en Totall. af

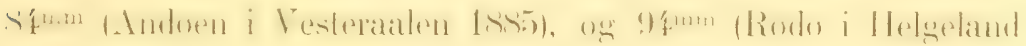
Febr. 1903).

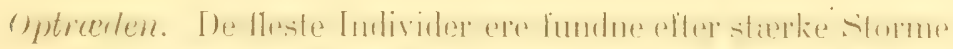

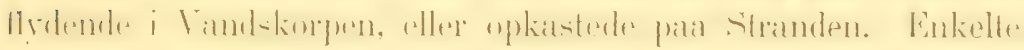
ere udtagne af de storre Gadiders Ventrikel (G. mowmuce og G. virens). I levende Tilstand vides intet Individ fundet hos os.

Forplantning. Som tidligere meddelt ${ }^{1}$, har et Ind., strandet ved 'Tromsøkysten i 1871, og afgivet til Chria.-Museet, vist sig at være rognfyldt ${ }^{2}$. Rognmængden havde, efterat Individet $\mathrm{i}$ flere Aar havde været oplevaret paa Spiritus, en Vægt af 0,285 Gram; Antallet af Rogn var omtr. 950, foruden en Del mindre, der syntes ikke at skulle udvikles. Eggene havde en Diameter

1 Medd. Norges Fiske 1879-83. (Nyt Mag. f. Naturv. 29) B., p. 103). Chria. 185.5.

2 Noiagtig Tidsangivelse mangler for dette Individ. 
(i praparenel Thilstand) af $0,5^{\mathrm{mm}}$, men denne har sandsynligvis i frisk 'Tilstand været noget større.

[Et nyt, stort Individ, hvis Totall. var $94^{\mathrm{mm}}$, strandede ved lindor i Helgeland efter en svaer Storm bte Febr. 190)3, og indsendtes til Chria.-Museet. Dette, der er det største af alle ved rore Kyster hidtil undersogte Individer, var en Hun med umodne liogn, der andsunliguis forst ud para Sommeren vilide have varet gydefærdige].

Fode. Hos et Ind., udtaget af Ventrikelen af en Gadus virens (bergen Marts 1865), fiundt jug i dens egen V'entrikel de halpfordoiede Tiester al en Maurolicus mälleri, hris Totall. havde været omtr: $50^{\mathrm{mm}}$.

\section{Argyropelecus aculeatus, Cuv. Val. 1849.}

Ny for Norges Fanma. Under et Ophold i Christiansund i Juli 18s!n tandt jeg i Latinskolens Samling et fuldstamdis uskadt Expl. af denne Art, der var indleveret til Skolen i et af Aarene 18S0 - S6), og urlen Trivl fundet, (i Lighed med de forholdsvis mange Indiv. af $A$. olfersii, som i Tidernes Løb ere skyllede iland red Golfstrommens Hjoelp paa Norges Vestlivst). paa et eller andet Punct af Kysten udenfor Byen, skjønt den nøiagtige Localitet ikke længer kunde oplyses.

Individet var en udvoxet Hun, med en Totall. af $70 \mathrm{~mm}$. Ovarierne vare rognfyldte, men Eggene vare endnu smaa og

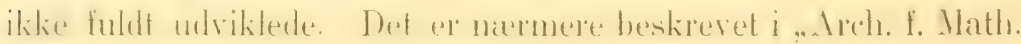
og Naturv." B. 23, No. 7, p. 22 (Chria. 1901).

Diagnose. Denne Art staar A. olfersii nær, men skiller

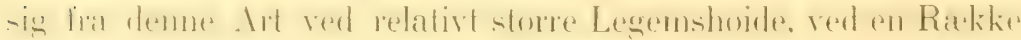
lave, tornede Kamme langs Legemets Ventrallinie, samt ved

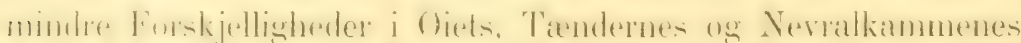

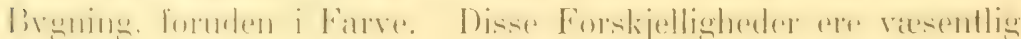
folgende :

Hos A. aculeatis er Legemshoiden storre, omtr. lig Af. standen fra Orbita til Haleroden; fremdeles er Halens under 
Profillinie forsynet med en Række lave, tornede Kamme. Hos A. olfersii er derimod Legemets Hoide lavere, omtrent lig Af-

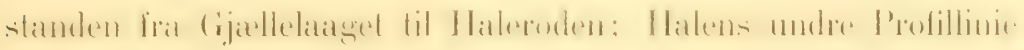
er glat (uden 'Torne).

Oiet er hos $A$. aculeatus relativt stort; dets Hoide indeholdes i Legemets 'Totallængde omtrent 8 Gange. Bredden er'

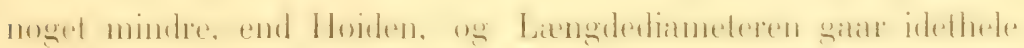
temmelig parallelt med Pandens Profil, hvorved Oiet faar en stærkere skraa Stilling, end hos A. olfersii.

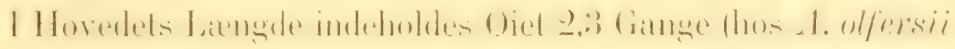
omtr. 2.8 Gange).

Endvidere kan navnes, at hos A. aculeatus ere alle Under-

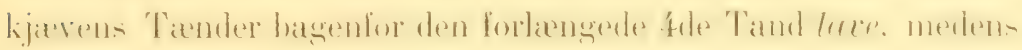
hos A. olfersii tlere af disse ere forlængede.

1ste Gjællebue har 16 "Tænder".

Tornevcebning. Straaleantallet er D. 9, A. $7+5$. Antallet er saaledes det samme, som hos A. olfersii; men Rækken er tildels afbrudt ved enkelte Torne, hvoraf 2 sidde foran, og 1 bag den Sde Analstraale.

Denne eiendommelige 'T'ornevæbning langs Halens Underside, der er characteristisk for denne Art, bestaar af folgende Dele:

1. En tandet Kam paa hver Side af Analspalten.

2. En kort vifteformig Kam, bestaaende af 2-3, hos et yngre Individ 7 'T'œnder, (hvoraf de mellemste ere de længste), mellem 7de og Sile Analstraale.

3. En enkelt Torn mellem Sde og 9de Analstraale.

4. En tandet Kam paa hver Side af Halerodens Ventrallinie i Mellenrummet mellem Analen og Caudalen. Kammen er noget udspærret foran Halerodens Lyspletter, men næsten sammenstodende paa Stykket mellem disse.

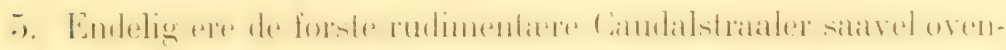
til som nedentil udspæerrede, og danne fri 'lorne.

Nevralkammen er hos $A$. aculeatus fint crenuleret i Randen; dens Hoide er storre, end Halerodens Hoide. Hos $A$. 
olfersii el Nevalkammen i Randen glat og forholdsvis lav; dens ILoide er her mindre, end Halerodens Hoide. Ogsaa Ventralkammen (form Anus) er fint crenuleret, og relativt hoiere hos A. aculeatus, end hos den anden Art.

\section{Udmaalinger.}

T'otallængde ........ . $70^{\mathrm{mm}}$ Snudespids til Halerod ...... . $56^{\mathrm{mm}}$ Hovedets Laengde til Gjællelangets Bagrand. $21 \mathrm{~mm}$ Hovedets Længde til Skulderen . . . . $24 \mathrm{~mm}$ Største Høide (til Grunden af D.) . . . . $41 \mathrm{~mm}$ Afstand fra Skulderkammen til Beg. af G. . $36^{\mathrm{mm}}$ Længde fra Skulderen til Spidsen af C. . . $52 \mathrm{~mm}$ L. fra Gjællelaagets Bagrand til Spidsen af C. $47 \mathrm{~mm}$ L. fra Beg. af Dorsalen til Beg. af Caudalen $36 \mathrm{~mm}$ Oiets Hoide-Diameter . . . . . . . $9^{\mathrm{mm}}$ Exemplaret opbevares nu i Chria.-Museet.

Areyropelecus hemigymuns, Cocco 1829.

Ny for Norges Fauna. I Febr. 1895 fandtes et Expl. af denne Art drivende i Stranden ved Udsiden af Kraloen Inax

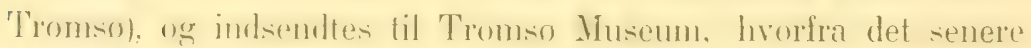
afgaves til Chria.-Museet $\left(70^{\circ} 30^{\prime}\right)$.

Totallienglen var $35.5 \mathrm{~mm}$, og Individed var saaledes omtrent udvoxet. Det var i alle Henseender normalt.

Ligenom de 2 foregaaende Arter er dette Individ loragt under lamd reel vore Kyster paa Golfstrommens vartie Bolger ${ }^{1}$. Det er nærmere beskrevet i "Arch. f. Math. og Naturv." B. 23, No. 7, p. 19 (Chria. 1901).

1 Ved Atlanterhavets nordostlige Dele var tidligere et enkelt Expl. af denne Art optaget fra en Dybde af 330 Meter af den engelske "Porcupine"-Expedition i 1869 i Faro-Renden (mellem Scotland og Freroerne). 


\section{Fam. Mamrolicidae.}

\section{Maurolicus mülleri, (Gmel.) 17881.}

Udbredelse. Denne Art (Prik-Fisken) synes at være sta-

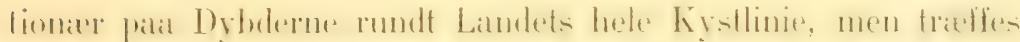

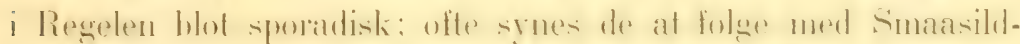

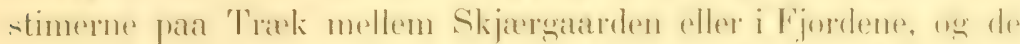

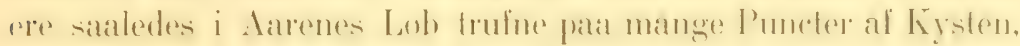
saavel ude i Havkanten, som lige op i Bunden af de storre

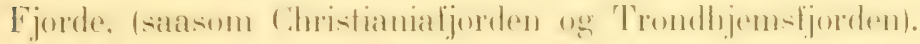

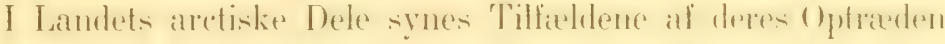
at være hyppigere, end paa andre Localiteter; det er idethele sandsublist, at .1. malleri har sil Hovedtilhold over Dybderne. i Allanterhavets nordligste Dele. og herfra leilighentsvis fores ind under Landets Kyster.

De fleste Tilfælde af deres Optræden ere kjendte fra Christianiafjurden, ulen at de her kumne ansees som hyprice, men hvor Iagttagelsernes Antal er storst. Individer ere her fundne

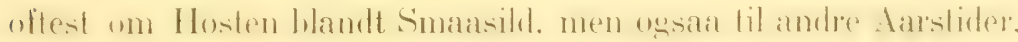
dog idethele neppe aarligt.

Fra Landets Sydkyst er et eller andet Ind. fundet udenfor

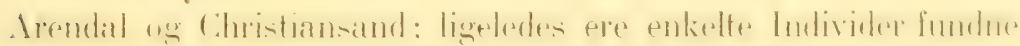
udenfor Stavangerfjord ug i Ilardangerfjondens Munding.

Fra Bergenskysten ere ligeledes sporadiske Individer ind-

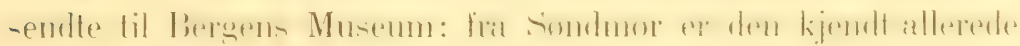

1 Efter en fornyet Gjennemgaaelse af de Stromske Dagboger fra den sidste Halvdel af 1700-Aarene, der i Manuseript opbevares paa Universitets-Bibliotheket i Christiania, er jeg med Prof. Smitt (Scandin. Fiskar, 2dra Uppl., B. 2, p. 93ュ, Amm. Stockh. 1895) enig i, at denne Arts rette Benavnelse er $M I$. mülleri.

Det maa nemlig ansees som utvivlsomt, at Gmelins Satmo mülleri (1788), der er grundet udelukkende pan den af Fabricius (Zoologice Danicce Prodromus, p. 49, No. 415) i 1776 givne Diagnose, alene har Hensyn til ovenstaaende Art, og ikke til den nordatlantiske Art af MIyctophum (Scopelus), som af Reinhardt i 1835 benavnedes Scopelus glacialis, og som Strom i 1791 (Skr. af Naturhistorie-Selskabet, 2 b., 2 H., p. 15) havde sammenblandet med Maurolieus mïlleri. 
1766, dat Strom ,med Haanden tog den lige af Havstranden ved min forrige Prastegaard i Wolden". Ted Romstalskysten er den fundet ved Christiansund.

I Trondhjemsfjorden ere ligeledes spredte Individer fundne hlandt Smaissild, eller ilanddrevne paa for:kjellige Localiteter lige op til Størdalsfjorden.

Ved Nordlandskysten vides blot ved et Par Leiligheder Individer fundue (sidste Gang ved TJotto i 1S72), men sandsynligvis strander den her ikke særdeles sjeldent.

Nordenfor Polar irkelen (i Landets arctiske Dele), haves det eneste Exempel hos os paa en hel Stimes Indsig under Kysten (Lyngen 1stiti): iovright ere spredte Individer fundne ved Trondenes, ved Tromso-Krsten, i Oxfjord, og ved Soroen (udenfor I Tammerfest).

Nordligst er et Ind. fundet ved Gjæsvær (paa Vestsiden af Nordeap) i 1ss6: fra Ost-Finmarken kjendes intet Tilfielde af deres Optræden.

Storrelse. Smaa Unger ere hidtil ikke fundne hos os. Det mindste Expl. fra Norge laa havt en Totall. af $41^{\text {min }}$ (Soroen red Hammerfest): fra Oxfjord haves ligeledes Unger med en Totall. af $433^{\mathrm{mm}}$. men fra Landets sydlige Krster blot storre Individer med en Totall. af omkr. $60-65 \mathrm{~mm}$.

Optroeden. Prikfisken har været fundet ved vore Kyster til alle Aarsider, om Vinteren, saavelsom om Sommeren, men whest under Fansten af Smaasild i Hosmaanederne. Dog have de bandt disse i Regelen blot været iagthagne tilfaldigt.

Adkillige Individer ere ogsan fundne flydende i Vandskorpen. eller strandede: andre ere udtagne af storre Fiskes Ventrikel, saasom af Gadus virens og G. morrhua. Som ovenfor

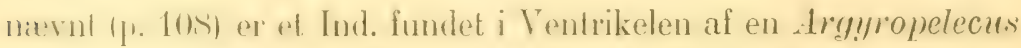
olferwii. Aer aller var bleven slugh af en Gadrs virens (Bergen Marts 1865).

Endelig er el Ind. optaget fra en Dyhde af omtr. 90 Meter monder de af l)r. IJjort drevne pratisk-hologiske Undersogelser af Christianiafjorden (25de Aug. 1895). 
1903.] MEDDELELSER OM NOLGES FISKE I AARENE 1881-1901. 11\%

I et enkelt 'Tilfæelde har det vist sig, at de kunne fore-

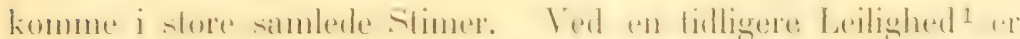
berort det mærkelige Indsig af denne Art, som fandt Sted i

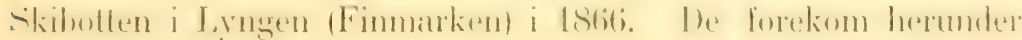
i saa store Stimer, at de bedækkede Stranden i tusindvis, og Individerme lod sige optage i spanderis af somen. for at loruges til

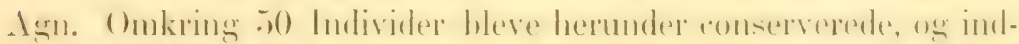

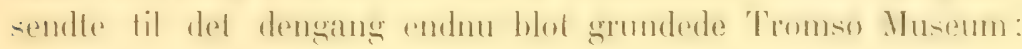
flere af disse opbevares endnu i Landets Museer.

Forplantmine. Inted af de Expl., jeg hidtil har molersoget fra vore Farvande, har havt moden Rogn. Hos det ovenfor umbalte Ind., der optoges udenfor Drohak fra en Dvbute af an Heter asde Ang. 1897, vare Eggene omtrent halvmodne. we vilde maaske have veret gydte engang i Vintermannederne.

Fode. De undersogte Exemplarer have indeholdt Copepoder, rasom Calumus finmarchicus og Methridia longa. Flene? Expl. havde valgt udelukkende den sidstnævnte Art.

\section{Fam. Myctophidae.}

Myctophum glaciale, (Reinh.) 1835-36.

Udbredelse. Allerede i Aaret 1774 blev det første kjendte Exemplar af deme Irt fumbet alf den gamle Naturforsker Stron i simdnor (indenfor Starltand); men senere er i Lobet af 100 Air blot 4 eller 5 lixpl. med sikkexhed natede under Land ved de nurske Krster, og blevne ophevarede. Disse are strandede eller langede par spredte Localiteler mellem Llardangerforden og Hammerfest: astenfor Nordap er drten ikke bemarket.

1. Hardangerfjorden. Et Expl., det første til et norsk Husem indlobne Exemplar, hlev afgivel til Pergens Musemm al stiftantm. Christie, og antoges al -lamme fra llardangerfjorden, hvor det var fanget engang i Aarene 1830-1840.

1 Norges Fiske (Tillægsh. til Forh. Vid. Selsk. Chria. 1874, 1) 152).

Vir.-Selsk. Forh. 1903. No. 9. 
2. Volden, Sondmor, 1774. Strom fandt sit Exemplar den inlie Iuni .. forfulgt af Morten" (Unger af radus-Arter) i Voldsforden: det heskrives udforligt i hans efterladte Daghog, som i Manuseript opherares paa Univ.-Bihl. i Christiania ${ }^{1}$ (Afsnittel for 1774 , No. 4).

I 1791 giver Strøm af det samme Exemplar en kjendelig Figur i en Afhandling „Om et Par rare Fiske" i .Skrifter at Naturhistorie-Selskahet" 12 B., 2- H., 1. 15. Khhvn. 179:3): men den ledsagende Text er uklar, og affattet dels efter ovenstaaende Exemplar, dels efter et tidligere (I/76i) fundet Indivii af Maurolicus mülleri².

3. Tromihjemsfjorden 18st. Et Ind. er fanget i Traw udenfor 'Trondhjem :30te Mai 1886. og ophevares i Thjems. Mus.

4-5. Hasvig 1864 og 1885 (Søroen ved Hammerfest). 2 Individer, begge ullagne af Ventrikelen af Iavtorsk (Skreil. Deres Totall. er $63^{\mathrm{m} m}$ og $75^{\mathrm{mm}}$; begge opbevares i Chria.Museet $^{3}$.

Udmaalinger: De 2 Exemplarer fra Otti-Aarene (a. Trond-

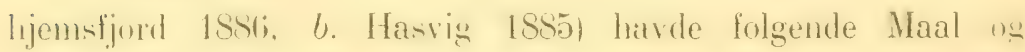
Straaleantal.

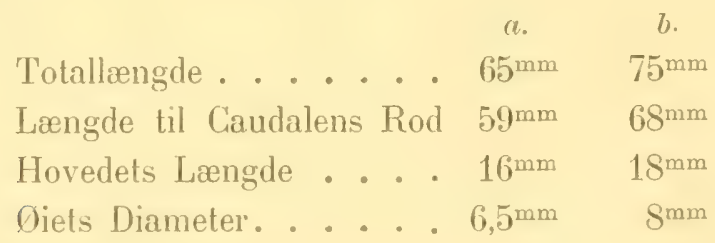

1 Hefternes Titel er: "Annotations-Bog over forefaldende Merkværdigheder i Natur-Historien par Syndmor" (2 Bind, 1756-1780).

2 Angaaende Artens Benævnelse (MIyctoplum [Scopelus] glaciale) henvises til p. 111, Noten.

Et Expl. af denne Art (Totall. 78mm) fandtes drivende i Vandskorpen 30te Juni 1876 under Nordhavs-Expeditionens 1ste Togt udenfor Stor. eggen $\left(63^{\circ} 5^{\prime}\right.$ N. B., $3^{\circ} 0^{\prime}$ Ø. L. Greenw.), som det antoges, udkastet af en Fiskemave.

Dette Exemplar har jeg tidligere (Forh. Vidensk. Selsk. 1879, No. 1. p. 85) opfort som henhorende under den norske Faunas Omraade; men efterat dette (efter Udgivelsen af de nyere Dybdekarter) bedre har kunnet fixeres, bor denne Station (No. 33) ansees som liggende udenfor den Linie, som rettelig bor henfores under det norske Kyst-Areal. 
Stracileantallet var hos a. D. 13, A. 17; hos b. D. 14, A. 18 .

Anale Lys-Pletter. Sangodtsom alle de fundne Exemplarer ere i mindre god Forfatning, og have varet optagne, som ovenfor nærnt, drivende i Soen, eller været udtagne af Fiske-Ventrikler; alene et enkelt Ind. er optaget med Trawl (Trondhjems.

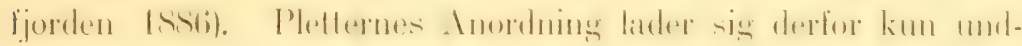
tagelsesvis iagttage $\mathrm{i}$ sin Helhed. Hos et af de $\mathrm{i}$ Chria.-Museet

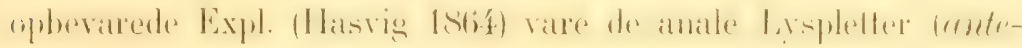
riores + posteriores $5+7$.

['Til Sammenligning kan anfores de samme Pletters Anordning hos 7 Expl., optagne under „Michael Sars" 1ste T'ogt

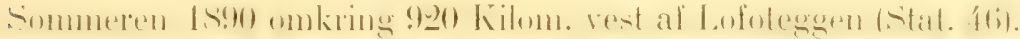
a. $6+7$
e. $6+$ ?
b. $6+7$
f. $6+5$
c. $6+7$
g. $5+6$
d. $6+7$

Disse Exemplarer havde en Totall. af $35-85 \mathrm{~mm}$. De varc

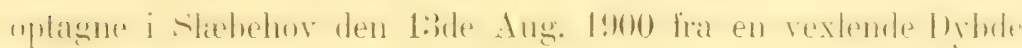
af $0-1000$ Meter].

Myctophum elongatum, (Costa) 1844.

Udbredelse. Af denne Art havde en hel Stime sit Tilhold

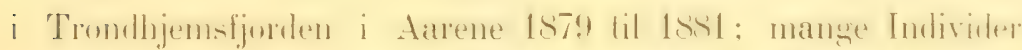

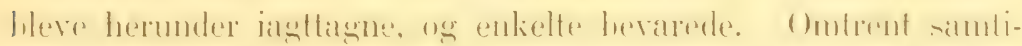
digt er et Individ (i Otti-Aarene) fundet ved Sorøen nær Hammerfest. Senere er Arten ikke iagttaget ved vore Kyster.

Som ved en tidligere Leilighed meddelt, bleve de forste Indi-

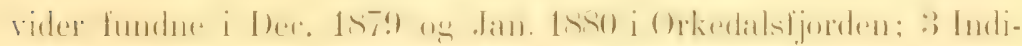

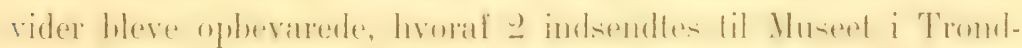
hjem. De syntes at have optraadt her i ikke ringe Antal under

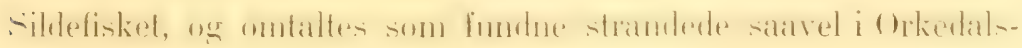
fjorden, som i Gulosen ${ }^{1}$.

1 Forh. Vid. Selsk. Chria. 1850, No. 8 (Scopelus resplendens, Rich.). Nyt Mag. f. Naturv. 29de B., p. 47 (1881); Storm, Kgl. N. Vid. Selsk. Skr. 1880 p. 78, og 1883 p. 30. (Thjem. 1881, 18si). 
Sommeren 1880 fandtes atter flere Individer $\mathrm{i}$ de samme Dele af Forden, og 2 nye Individer bleve indsendte til Trondhjems Museum, foruden 1 fra Rissen (paa Fjordens Nordside).

Endmu i $18 S 1$ bleve de bemarkede i Trondhjemsfjorden, men noget Ind. bleve dette Aar ikke ophevaret. Senere vides de ikke at have været iagttagne her.

Til den Beskrivelse af de forst erholdte Exemplarer, som jeg har meddelt i 1850, har Conserv. Storm (i 1883) kunnet foie (n) Del supplerende Bemærkninger vedrorende de Exemplarer, der senere (Sommeren 1880) bleve fundne.

De rodgule Nakkepletter have saaledes vist sig at strække sig i 2 Rxkker lige hen til Dorsalen, og hver af disse tælle 16 Pletter. Sideliniens Skjæl ere hos Storms Exemplarer 45 (eller lidt derover), saaledes talrigere, end hos de 2 af mig undersogte, hvor Antallet blot syntes at være 38 eller 39.

Udmatinger. Af de i Trondhjemsfjorden i 1879 og 1880 erholdte Exemplarer opbevares for Tiden $1 \mathrm{i}$ Chria.-Museet, ㄴ i Trondhjems Museum. 1 i Bergens Museum. 3 af disse havde folgende Maal:

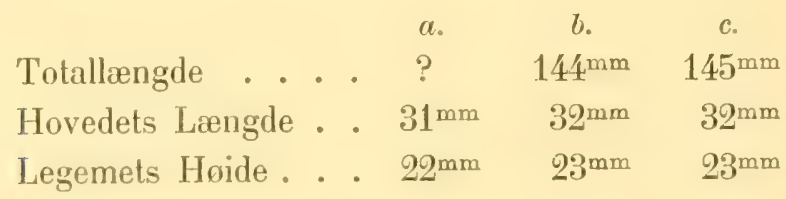

Fimmark-Exemplaret. Under et Besog paa Hasvig paa Sorren i 1994 modtog jeg af IIandelsmand Bull et Exemplar af denne Art, fundet i ()tti-Aarene udenfor dette Fiskevær, og sandsynligvis udtaget af Ventrikelen af en større Fisk.

Dettr er det nordligste Sted, hwor denne Art vides iagthaget $\left(70^{\circ} 30^{\prime}\right.$ N. B.).

Jette Exemplar, der var slet vedligeholdt, havde omtrent samme Storrelse, som de tidligere erholdte. Det ophevares $\mathrm{i}$ Chria.-Museet. 


\section{Udmaalinger.}

Totallængde . $143^{\mathrm{mm}}$

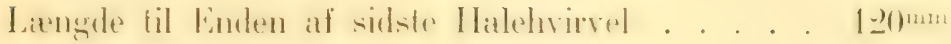

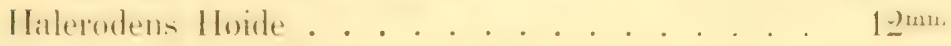

Hovedets Længde . . . . . . . . $31^{\mathrm{mm}}$

Oiets Diameter . . . . . . . . $7,5^{\mathrm{mm}}$

Hovedets postorbitale Del. . . . . . . $21^{\mathrm{mm}}$

Mundspaltens Længde ......... . $22 \mathrm{~mm}$

Pectoralens Længde . . . . . . . . $11 \mathrm{~mm}$

Ventralens Liengde . . . . . . . . . 15,

Fra Snudespids til Dorsalen . . . . . . $50^{\mathrm{mm}}$

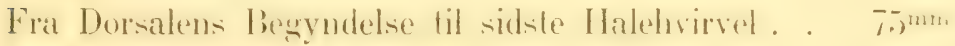

Fra snudespids til Analen . . . . . . . . . $7 l^{1}$

Straaleantallet var: D. 21; P. 13; V. S.

Storrelse. Alle hidtil erholdte Exemplarer have vierel fuld udvoxede, og have havt en jevn Størrelse af 143-145 mm.

Forplantuing. I)et i (hria.-Museet opbevarede Expl. fra 'Trondhjemsfjorden, fundet i Dec. 1\$79, er en Hun med rel ud. viklede Ovarier, (disses Langde or omtr. $3\left(\mathrm{mmm}^{\mathrm{mm}}\right)$. Figgene vare endnu umodne, og vilde maaske have været gydte $\mathrm{i}$ de første Vaarmaaneder.

\section{Fam. Sudidae.}

Sudis kroyeri, Ltk. 1891.

Ny for Europas Fauna. Et Expl. af denne forst i 1891 af Lütken tharateriserede Art, (af hrilken Typ-Fxemplarerme tilhore de addre gronlandake Samlinger i Museet i Konhenhavnl,

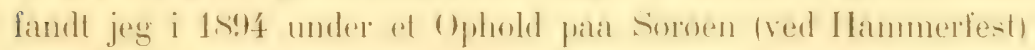

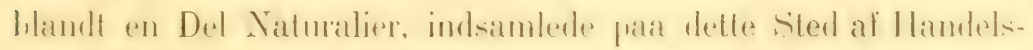
mand liull i otli- og Nilli-Aarene. Exemplaret var udtaged a!

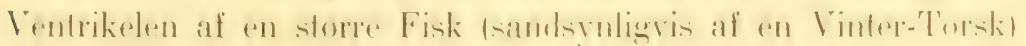
omkring 1885, og opbevares nu i Chria.-Museet. 


\section{Udmcalinger.}

Totallængde. . . . . . . . omtr. $242^{\mathrm{mm}}$

Længde til Enden af Hvirvelsoilen . . . . $234^{\mathrm{mm}}$

Hovedets Længde ......... . 49mm

Snudespids til Dorsal. . . . . . . $148^{\mathrm{mm}}$

Sundespids til Ventral ........ $164^{\mathrm{mm}}$

Legemets storste Høide. . . . . . . . 19 19mm

Afstand fra Fedtfinnen til Caudalen .... $4^{\mathrm{mm}}$

Exemplarel, der var slet vedligeholdt, og hvis Undersogelse har varet noget vanskelig, svarer $\mathrm{i}$ alle sine tilgjængelige $\mathrm{De}$ tailler til Lütkens Beskrivelse af Arten i „Korte Bidrag til Nordisk Irhthyographi“ VIII, p. 201. . Det er nærmere omhandlet i "Archiv for Math. og Naturvid." B. 19, No. 8 (Chria. 1897).

Hovedet indeholdes saaledes hos dette Individ næsten 5 frange i Totallixnglen (4.93). eller $4: 3 / 4$ Gange $(4,77)$ i Legemets Længde til sidste Halehvirvel (Lütkens Totallængde).

Oiet indeholdes i Hovedets Længde ikke fuldt 5 Gange (4,90), i Sumdelengden ikke fuldt $21 / 3$ Gange $(2,30)$, og i Hovedets postorbitale Del lidt over 1/2 Gang $(1,60)$.

Legenets Inide indeholdes i Totalliengden 122/3 Gange

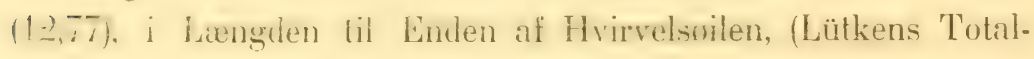
længde), 12//3 Gange (12,31).

Ventralerne kumne sees at sidde hagentor sidste Dursalstrasle. og Ferltinnen ganske nær Caudalen.

sidelinien kinn forfolges indtil i omtrent 1 Hovedlengdes Afstand fra Candalen. og tieller indtil dette Punct (je Porer; paa det manglente siglike. (hwor Huden er afreven), har antagelig været omtr. 14 Porer, tilsammen omtr. 76 Porer.

Ganens lange Tænder ere 6, Underkjæevens 10. Iovrigt er Tandvæbningen som af Lütken beskrevet.

Al denne Slirgt eier Museet i Kjohenharn enkelte mindre vel redligeholdte homodiske Exemplarer eller Brudstyker, tilveiehragle gjenm.m Reinharil og Krover, som sammenfalte alle

1 Vidensk. Medd. Naturh. Foren. Kbhun. 1891, p. 222. 


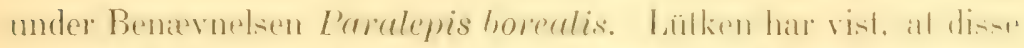

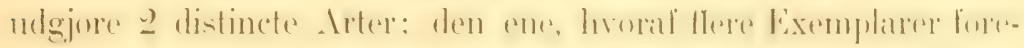
ligge. saavel fra Gronland, som fra Island, er at ham givet

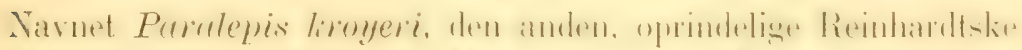

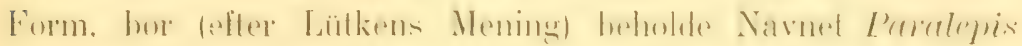
borealis.

Ved de europaiske Kyster vides S. kroyer i ikke tidligere med Sikkerhed iagttaget.

\section{Fam. Salmonidae.}

Salmo salar, Lin. 1766.

Opstigningen. Tiden for Laxens Opstigning fra Havet er i Norge ikke ubetrdeligt forskjellig i de forskjellige Filve, men ex for hrert enkelt Tasdrag forholdsvis conskant fra dar til andet.

Dog er Opstigningen ogsaa i hver enkelt Elv noget foranderlig, idet den, især $\mathrm{i}$ de mindre Elve, i nogen Grad paavirkes af Regnflommens tilligere efler senere Indraxden i de forskjellige Aar.

I enkelte Elve foregaar saaledes Opstigningen for Midten af Mai, medens den for de flestes Vedkommende foregaar i Juni ${ }^{1}$.

Ved Mærkningsforsøg, der i Lobet af de senere Aar med

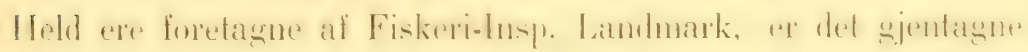
Gange godtgjort, at Laxen i de fleste Tilfæelde soger op i den Elv, hvor den selv er fodt, for at gyde. Under sin Vandring fra Havet mod Kysten stoder den imidlertid ofte under Land i betydelig Afstand fra den Elv, hvori den senere skal stige op.

Indsigene gjennem Fjordene foregaar i Regelen med moderat Hurtighed, og Laxen gjor ofte storre eller mindre Ophold

sn Rrokke Tabeller, indeholdende en detailleret Oversigt over Tiden for Opgangens Begyndelse og dens Afslutning $\mathrm{i}$ de fleste af vort Lands Laxe.Elve, er meddelt af Fiskeri-Insp. Landmark i Storth. Forh. 18ss. Oth. Prop. No. 13, p. 14. 
underveis. men kan dog hevislig flytte sig mellem 10 og 20 Kilometer i Dognet.

Anderledes er det i Elvene, hvor Ernæringen er uden Betrdning. Her foregan Opstigningen ofte med hetydelig Hurtighed; i Tana-Elven erholdes undertiden Laxe med frisk Sil 1.1 mmorlytes) eller Lodde (Mallotus) i Ventrikelen i en Afstand fra Søen af mellem $30 \mathrm{og} 40$ Kilometer.

I Tana-Elven naar Laxen op i en Afstand fra Søen, der er flere Gange storre, end i nogen anden norsk Elr. Den stiger her (ifolge Landmark) i Bantajok op til ontrent 30 Kilometer wenfor denne Elys Sammenlob med Karasjok, eller i en VandAfstand fra Elvens Munding af omtr. 300 Kilom.

Gydetid. Laxens (rydetid falder i Norge for de fleste Elves Vedkommende i october og den forste Ilalvdel af November; i cnkelte Five hegynder den allerede sidst i September, $\mathrm{i}$ andr. forst senere, i Norember og December, eller tildels endog kort over Nytaar.

Piognens Lillitrkining $i$ Saltvand. For at undersnge et af Fiskere reist Sporgsmaal om, hvorvidt Laxens Rogn kan komme til Ldvikling i selve Soen, er ved Bergens Biologiske Station af Dr. Nordsaard i Aarene 18sti-189s anstillet en Rikke Forsog, af hvilke ere fremgaaede folgende Resultater ${ }^{1}$.

Laxen lian ulvikle sin Rogn og Melke til fuld Molenhed i suen (Saltvand af rirca $: 3^{\circ}$ o). og lian her anlægge sin Parringsdragt, selv om den ikke kommer op i nogen Elv.

En Befrugtning af Rogn i Saltvand bevirker, at denne ncesten altid gaar tilgrunde.

Den gydte Rognns videre ITwikling lion loregan i sragt salthoddigh Vand (Brakrand af circa $1^{0}$ o). men en Ldvikling i Soen (med almindelig Saltgehalt) er umulig.

Ingrenes Toudringer. Ender de af Dr. Dahl i 189S-1902 ofter offentlig Foranstaltning anstillede Condersogelser anganende

1 Nordgaard, Bergens Museums Aarbog 1896, No. IV, og 1898, No. VIII (Bergen 1897 og 1599). 


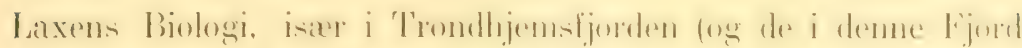

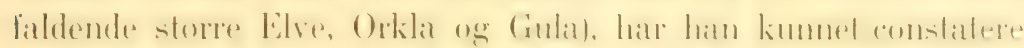
llere. 'Trak af Interesse vedrorende Laxe-Ungernes Ophold og forste Vandringer.

Skjont disse Undersogelser kun ere foretagne i et enkelt District, kan det neppe betvivles, at de $\mathrm{i}$ sine Hovedtrak have almen Gyldighed.

1 'Trondhjemsfjordens Elve og Elvemundinger have Laxe-

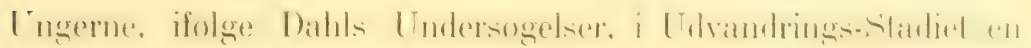
Storrelse af indtil $130^{\mathrm{mm}}$; de fleste ere omkring $110^{\mathrm{mm}}$, og kun

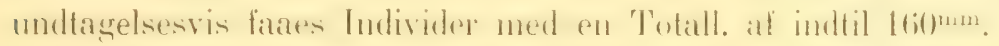

I Gula og Orkla begynder Ungernes 'Trak mod Havet i Mai. 'Trækket vedvarer hele Sommeren igjennem; Ungerne

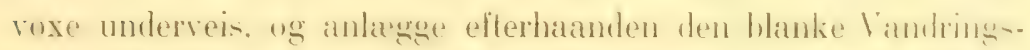

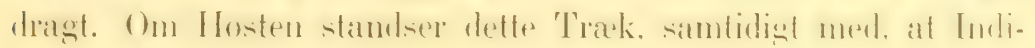
vidernes Væxt standser'.

De fleste af disse Udvandrere maa antages at være udklækkede det foreganende Aar, og ere saaledes, naar de naa Havet, $11 / 1-11 / 2$ Aar gamle.

I Landets sydligere Elve synes Ungerne i UdvandringsStadiet gjennemgaaende at være storre, end i Orkla og Gula.

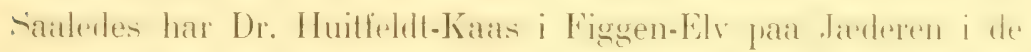
forste Dage af Oct. (1902) opfisket Unger med en 'Totall. af $170^{\mathrm{mm}}$, og ikke engang alle disse syntes at ville udvandre samme Aar.

Ungernes Væxt antages i den sidstnavnte Elv at foregaa saaledes:

1. Om Hosten det 1ste Aar ere Ungerne omkring $60-60 \mathrm{~mm}$ lange.

2. I Juni naste Aar er Langden $80-100^{\mathrm{mm}}$, saaledes en 'Tilvaxt i Vinterens Lob af omkr. $20 \mathrm{~mm}$.

3. I October 2det Aar, (naar Ungerne ere 11/2 Aar gamle), - er Langden $130-170^{\mathrm{mm}}$. Blot en Del af disse, hvis Dragt er

1 Dahl, "Orret og unglaks, samt lovgivningens forloold til dem". (Chria. 1902).

Norsk Fiskeri-Tidende 1903, p. 2333. 
naaet langst (Stir-Dragten), kunde antages at ville udvandre samme Host, medens Resten bliver endnu en Vinter over i Elven ${ }^{1}$.

Ing-Iare $i$ Hacel. Efter Idvandringen tillninge Ungerne sin naste Periode i selve Havet, og de vende ikke tilbage til Kisten, Fjordene eller Elvene, for de have naaet en Storrelse af omkr.1/2 Meter eller derover.

Denne lagttagelse, der tidligere hlot var en los Formodning², (u' forste Gang bleven fremstillet og bevist af Dr. Dahl ved hans ovennitunte Indersogelser i Trondhjemsfjorden. Lng-Lax med ('ll 'Totall. af mellem $170 \mathrm{~mm}$ og omkring 450$)^{\mathrm{mm}}$ ere derfor satgodtsom ukjendte $\mathrm{i}$ vore Farvande, idet de $\mathrm{i}$ denne Alder ude. lukkende have sit 'Tilhold i ITave i storre elier mindre Afstand fira Land.

Denne Antagelse vinder yderligere Stotte derved, at UngLax i llav-stadiel af sidstuevnte Storrelse saagodtom aldrig are erholdte al Limdets forskjellige Samlinger. I Museerne findes saaledes for Tiden blot 2 Individer, (begge i Chria.Museet), muligens de eneste sikre Lng-Lax i dette Stadium, som for Tiden ere opbevarede fra vore Farvande ${ }^{3}$.

${ }_{1}$ Om Individernes Vaxthastighed i Soen har Fiskeri-Insp. Landmark meddelt en Række oplysende Tabeller i hans 4 Indberetninger om Ferskvands-Fiskerierne for 1887-1890, for 1891-1894, for 1895-1896, og for 1897-1898.

- Allerede i 1896 blev dette udtalt som en Formodning af Fiskeri-Insp. Landmark, stottet dels til hans egne Iagttagelser, dels til de Under. søgelser, som Fiskeri-Assistent Simomes paa hans Anmodning havde anstillet anganende de Ungformer af Salmonider, som under forskjellige Navne (især Blerge) i stort Antal fanges i Søen udenfor vore Kyster, og som viste sig at være uden Undtagelse Orretformer (Fiskeri. Inspectorens Indberetn. om Ferskvandsfiskerierne 1895 og 1896, p. 19, og p. 103).

Ifolge denne Antugelse foresloges derfor i 1895 en Bevilgning til "Undersogelser angaaende Laxyngelens Vandringer", en Opgave, der blev overdraget Dr. Dahl, livis indgaaende Undersogelser synes at have bragt Sporgsmaalet udenfor al T'vivl.

3 I Bergens Museum opbevares 2 unge Individer, (ifolge Dr. Dahls Maalinger 205 og $215 \mathrm{~mm}$ lange); disse have veret opdrettede i Fangen. skab i en l'erskvandsdam paa Jæderen. 
Naar Ungerne ere komne udenfor Elvemundingen, trække de hurtigt videre ud $\mathrm{i}$ Havet; under denne Vandring blive de

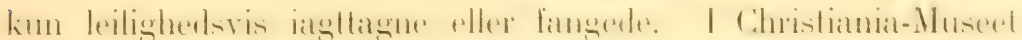
opbevares dog 2 nylig udvandrede Unger, udtagne af Ventrike-

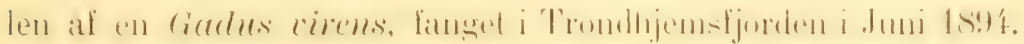
Deres 'Totall. er 126 og $128^{\mathrm{nm}}$.

On Ung-Laxens Ophold i Havet udenfor vore Kyster foreligge hidtil kun faa positive Iagttagelser. De lleste Makrel. Fiskere berette, at de faa en og anden Ung-Lax paa Garnene

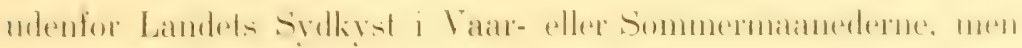
blot undtagelsesvis ere disse bragle til Land, og ere blevne undersogte.

Som ovenfor nævnt, eier Christiania-Museet 2 saadanne UngLaxe, hvis Totall. er 235 og $280^{\mathrm{mm}}$. Begge disse ere indkjobte af mig paa Fisketorvet i Christiania i Aug. 1886. Den mindste var fanged lode dugunt blandt sman-Makrel (yogre Individer med en Totall. af omkr. $240^{\mathrm{mm}}$, altsaa omtr. af Laxe-Ungens

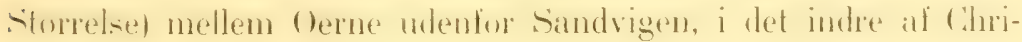
stianiafjorden; det andet var langet ligeledes i Fjordens Bund nogle Dage senere.

Et Ind., som undersogtes af Assistent Simonnæs, var fanget

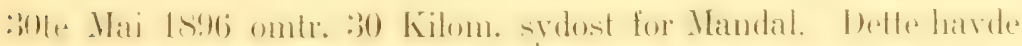

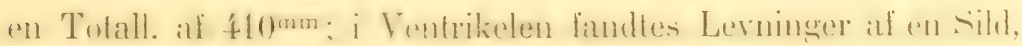
(hvis L. havde varet omkr. $160^{\mathrm{mm}}$ ).

I Mai og Juni 1901 undersogtes af Dr. Dahl 3 lignende Individer. alle fangede 20 sol Kilemeter sid for Christiansiand; det storste af disse havde en Totall. af $430 \mathrm{~mm}$.

Efter Fiskernes Opgave gaa disse Ung-Lax helst paa Makrel-Garnene i morke Nætter; de synes at fardes i de ovre Vandlag, da de sjelden fanges $\mathrm{i}$ storre Dybde, end $1-1^{1 / 2}$ Meter under Vandfladen.

Leilighedsvis faaes ogsaa paa Makrel-Garnene udvoxede Lax, der opgives at være $\mathrm{i}$ godt Huld, og $\mathrm{i}$ Regelen fuldproppede af Fode (Sild).

At Ung-Laxene i sit "pelagiske" Stadium sporadisk ogsaa

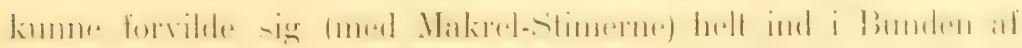


de storre Fjorde. fremgaar af de ovennernte Fund fra Christianiafjorden.

l'nder Vinteren kommer Laxen regulært ikke under Land red de norske Kyster. Dog fanges mu og da et og andet Exemplar ogsaa paa denne Aarstid, men dette omlales i Regelen -om en Mierkelighed. Et saadant, fanget udenfor Egersund 277de Dec. 1S9\%, var af Middelstorrelse (Vegt \& Kilogr.); et andet Lxpl. langedes ved ()rokog (Sondmor) i en Kastenot efter SmaiSei i Midten af Dec. $18 \%$ (Vougl omtr. 12 Kilogr.). Lignende Tilfixlde kunne herettes af Fiskere paa flere Steder rundt Kysten. Disse Exemplarer angives ofte at være $\mathrm{i}$ slet Huld.

Derimod kan i de fleste storre Elve et og andet Individ hlive tillage om Insten, og friste Livet Vinteren over (.. VinterStonninger"), men disse ere om Vaaren strerkt afmagrede, da Naringen i de strerkttlydende Elve er utilstrækkelig. Nogle Individer fra Saltdalselven (indenfor Bodo), der undersogtes af den aldre Sommerfelt henimod Vinterens Slutning, havde i Ventrikelen snegle, Phrygané-Larver (saaledes (Mrretens Fode), og rngang en liden Aal. Ved enkelte Leiligheder kunne flere Individer eller hele Selskaber af en eller anden Grund blive hindrede fra at søge Havet om Høsten ${ }^{1}$.

Locale Trextforhold. En Raxke (af Fiskeri-Insp. Land. mark udforte) Maalinger og Veininger af Laxe fra forskjellige Landstele udviser, at Forholdet mellem Longden og V'xgten ikk? altid er den samme overalt langs Kysten.

Salaledes har den Stamme, der bebor hegge Bergenhus- on Condre Trondhjems Amter, gjennemganende en mere sammentrangt Legemform, end f. Ex. den Stamme, der tilhorer Jæeler.n og lister og Mandals Amt. Et Individ fra Landets sydvestlige Dele vil saaledes have en ikke ubelydelight ringere Vagt. end ef lige langt Individ fra Bergenskysten og del Trondhjemske”.

1 I Storelven (Geiranger) drev saaledes engang i Nitti-Aarene under Islosningen om Vaaren et Par Hundrede dode Laxe, der havde staaet Vinteren over i Elven, ind ved Bredderne.

2 Et Ind. med en Totall. af $900 \mathrm{~mm}$, fanget ved Christiansand, har saaledes gjennemsnitlig en Vrgt af $\mathbf{6 , 5 5}$ Kilogr., medens et Ind. af samme Liengde fra Bergenskysten veier omkr. 8,50 Kilogr. 
1908.] MEDDELELSER OM NOHGES FISKE I AARENE 188.1-1901. 195

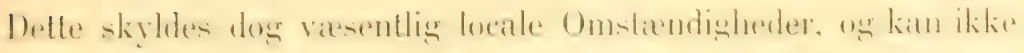
hringes ind moler bestemle Regler efter situlels bediggenterd.

Store Expl. Af sarligt store Individer fra de senere Aar har jeg fundet folgende omtalte:

\begin{tabular}{|c|c|c|c|}
\hline & $\begin{array}{l}\text { Total- } \\
\text { længde }\end{array}$ & Omkreds & Vaegt \\
\hline & $\mathrm{mm}$ & $\mathrm{mm}$ & Kilogr. \\
\hline Helle, Arendal 26de Mai 1893 & 1438 & - & 20,4 \\
\hline Aaroen, Sogn 12te Sept. 1902 ... & 1200 & - & 21 \\
\hline storelven, Giluppen 1Sde sept. 1899. & 1211 & - & 21 \\
\hline Sluppen, Nidelven 15de Juni 1903. . & - & - & 21 \\
\hline Sandselv. Ryfylke Juli 1903 . . . . & - & - & 21,5 \\
\hline Nidelven Juli 1902 . . . . . . . . & 1180 & - & 22 \\
\hline Tigeland-fos. Chr.sand :30te .Juli 189!) & li:?n & :35) & 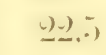 \\
\hline Namsen-Elv 24de Aug. 1897 . . . . & - & - & 22,8 \\
\hline Trondhjemsfjord Mai 1901 . . . . & 1150 & 740 & 23 \\
\hline Flaam 20de Dec 1902. . . . . . & 1260 & - & 24 \\
\hline Rokenstranden Juli 1899 . . . . . & - & - & 24,1 \\
\hline Bolstadelv 25de Juli 1901 . . . . . & 1300 & - & 24,1 \\
\hline Bolstadelv 1Sde Juli 1901 . . . . & 1310 & 一 & 24,5 \\
\hline Drammensfjord 3die Juni 1900 . . & - & 一 & 24,5 \\
\hline Aaroelv, Sogndal Aug. 1899 . . . & - & - & 25 \\
\hline Sogndal 21de Juni 1903 . . . . . & 1023 & - & 26 \\
\hline Stryenselv, Nordfjord 21de Aug. 1895 & 1330 & 700 & 26 \\
\hline Namsen-Elv 24de Aug. 1S97 . . . & - & - & 26 \\
\hline Evanger, Voss 11te Juli 1902. . . . & 1300 & - & 26,3 \\
\hline Gjæsdal 3die Juni 1900 . . . . . & - & - & 26,5 \\
\hline Namsen-Elv 1886 . . . . . . . & - & - & 26,8 \\
\hline Pasvigelv, Syd-Varanger Aug. 1897 . & 1300 & - & $2 \pi$ \\
\hline Bolstadelv 20 de Juni 1902 . . . . . & 1028 & - & 27,5 \\
\hline Namsen-Elv 1894 . . . . & - & - & 28,8 \\
\hline Aaroelv, Sogndal 1894. . . . . & 1412 & 740 & 30,5 \\
\hline Aaroelv, Sogndal Aug. 1884 . . & 1551 & 770 & 30,5 \\
\hline Sogndal Aug. 1894 . . . . . & 1245 & - & 31 \\
\hline Aaroelv, Sogndal Aug. 18S4 . . & 1551 & 770 & 31 \\
\hline Tanaelv Aug. 1879 . . . . . & - & 一 & 33, \\
\hline Pasvigelv, Syd-Varanger 1853 . . . & - & - & 36 \\
\hline
\end{tabular}


I Fangenskab. En Del Laxe-Unger i Vandre-Stadiet, som af Dr. Dahl holdtes levende frorst i Ferskvand, senere i Saltrand. ten Orerflytuing som let taaltes). gav Antedning til enkelte Iagltagelser af Interesse over deres Væsen ${ }^{1}$. Disse Unger, som i Midten af Juni vare omtr. $130 \mathrm{~mm}$ lange, havde i Aquarium i Midten af October naaet en Længde af 230 til $315 \mathrm{~mm}$.

Medens Orret-Unger af samme Storrelse og under lige Forlookde i Fangenskibed holdt sig nasten ubevageligh sverende. hele Dagen, og blot af og til gionde et raskt Sprang for at gribu. Fode, sirmmede Laxe-['ngerme Nat og Dag i maflutelig Berasgelse rundt i Aquariet.

Simmen med deme Rartloshed hos Laxe-L'ngerne fulgte en storre Fierdighed i Brugen af Pectoraleme. Hvis en Samling levende Unger af Lax og Ørret bleve lagte torre f. Ex. paa el skrat skibsdirk, bleve alle orret-Lngerne liggende sprollende paa Siden, medens Laxe-Ungerne. alle som en reiste sig paa Fugen, stoftende sig paa Brystfinnerne: alene paa Grund af

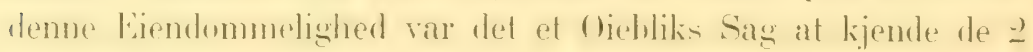
Arter fra hinanden.

Og medens Ørretens Appetit var vexlende, idet de enkelte Dage fastede, paa andre helt fyldte sin Ventrikel, saa at de undertiden kinde ligge i flere lage paa Bunden og fordrie, tow Laxe-Lingerne som Regel Fode flere Gange hrer Dag, men mindre ad Gangen, og fordoiede hurtigt.

\section{Salmo eriox, Lin. 1766.}

Ncring. Orretens Hovednæring hos os er Fiske, Crustaand: Inseder eller Mollusker. Denne Nixring hentes after On-

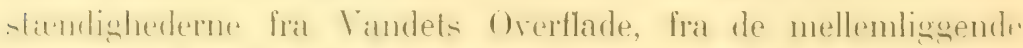

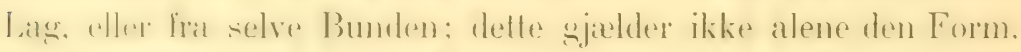

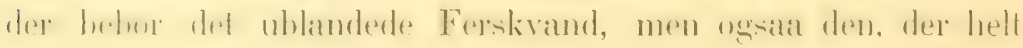
eller for en væsentlig Del er knyttet til Havet.

I Dahl, Orret og unglaks, samt lovgivningens forhold til dem, p. 10. (Chria. 1902). 
I. Saltvandsformen (So-Orret, Blege, etc., S. eriox,

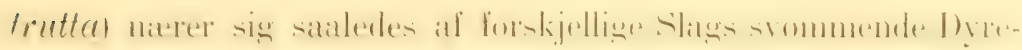
former fra Overfladen til Bunden, men dens naturlige Naring, hvoraf den henter sin Fedme, er uden 'Tvivl Fiske, fremfor' alt Sild.

a. Hos Individer ('T'otall. omkr. $300 \mathrm{~mm}$ ), fangede i Vaar-

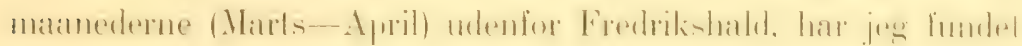
folgende Fode:

Fiske-Yngel (af Sild eller Clupea sprattus); hos enkelte Individer udelukkende Smaasild. Andre havde mindre Surand-

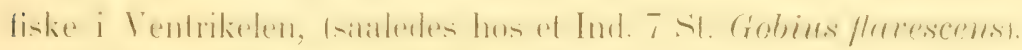

Dernæst Crustaceer; hos enkelte Ind. fandtes udelukkende disse, hos andre blandet med Fiskefode. Disse Crustaceer vare

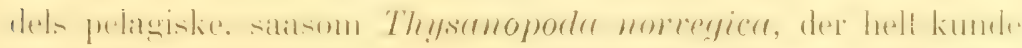
fylde Ventrikelen, dels mere littorale, sansom Mysis flexuosa, Gammanus locusta, en og anden Metopa, og Palaemon fabricii.

b. Saltvandsformens Nreringsmidler i Sommermanederne (April-October) ved Landets sydlige Kyster have i Aarene 1896 og 1897 varet Gjenstand for en speciel Undersogelse (mellem Lister og Sondmor) af Hr. Simonnæes ${ }^{1}$. Antallet af de under-

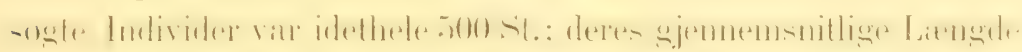
var omkr. $300^{\mathrm{mm}}$, leilighedsvis noget storre eller mindre.

Over Halvdelen af dette store Antal indeholdt udelukkende

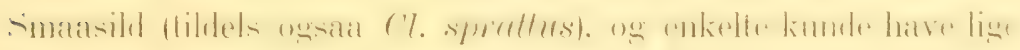
indtil 12-20 saadanne i Mavesxkken.

Af Fisk var dernæst hyppigst Yngel af Ammodytes, hvoral

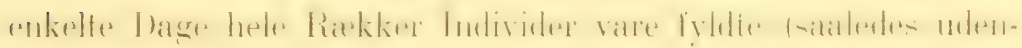
lor Sondfjord i Juli 1S97).

Srrdeles hyppige vare ogsaa Crustaceer (Arterne ubestemte). som ofte ligeledes helt kunde fylde Ventrikelen.

Mange Individer vare ogsaa fyldte med Insecter, som de saaledes havde hentet i Vandskorpen nær Land, eller i Elvemundingerne.

1 Fiskeri-Inspectorens Indberetn. om Ferskvandsfiskerierne 1895 og 1896 , p. 106-145. (Chria. 1899). 
If mere spredt forekommende Fodemidler kunde blandt Fiskene nirves forskjellige Gadider, saasom en og anden SmaaTorsk, I lwitting, eller Lyr ( $\boldsymbol{F}_{i}$. pollachius). Hos enkelte fandtes Makrel-Lnger (med en L. af 8()$-170^{\mathrm{mnn}}$ ); leilighedsvis fandtes unge ()rreter (ikke hyppigit), og en og anden ung Aal, tildels Yngel i Montée-Alderen (L. $70^{\mathrm{mm}}$ ).

Flere Ind., fangede i Mai, indeholdt fremdeles et eller flere Expl. af Rihamphistoma belone; sailedes fandtes hos et (Làng-

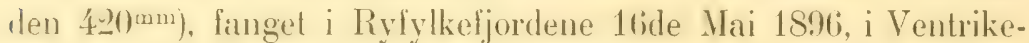
len 5 Expl., hvis L. var fra $100-150^{\mathrm{mm}}$. Et andet (L. 255 $\mathrm{mm}$ ), finget udenfor Listerland 20de Mai 1896, indeholdt S smaa Individer af denne Art.

De Fiske, som sluges, ere olte af forholdsvis hetydelig Storrelse. lit lixpl., hvis $L$. var :S80mm (Lister 2'tde Mai 1896), inde. holdt fforuden Rester af Sild) en Gadus merlangus, der var $230^{\mathrm{mm}}$ lang.

I Landets nordlige Dele indtrade tildels andre Arter blandt su-Grretens Fode. Et Ind., langet i Balsfjord indenfor Tromso تtlen Aug. (1903), og nedsendt til Chria.-Nuseet, indeholdt foruden Unger af Sild og Sil (Ammorlytes), tillige Unger af Lodde (Mallotus).

Ungerne, som i stort Antal kunne optages langs Land og i Elvemundingerne om sommeren, ernære sig vasentlig af littorale finstaceer, saasom Gommarms locusta og Idothea tridentata, $0 g$ andre.

c. Hos Host-Exemplarer fria (hristianiafjord, fangede tole sept. (190:)), har jeg fundel en handet Fode af Fiske og Insecthr. Iner har forekommet Svierme-Nyrer i stort Antal (vingede Ind. af F. fusce og af Myrmica-Arter), pai enkelte Dage i hn-indvi-; leilighedsvis ogsan andre skihbrudne Insecter. Fiskene have virret Smaasild eller Gohier; et Ind. havde fundet Ungerne af Crystallogobius linearis.

Ston. Fxpl. (Sponviken „bide ().t. 1!10:3) vare fyldte udelukkende med Smaasild og Brisling ( $C l$. sprattus).

II. Ferskvands-Ørreten henter sin Fode, alt efter Aarstirl og Lowalitet, i alle Vaudlag fra Overflaten og til Bunden. 
Denne Forms Ernaringsforholde ere i de senere Aar, for de

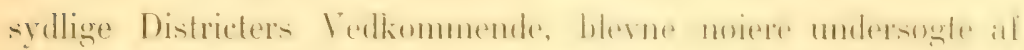

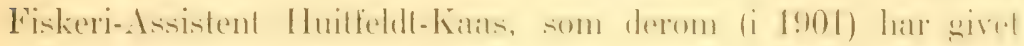
en Del forelobige Meddelelser ${ }^{1}$.

a. Den Fode, som hentes i de overste Vandlag, bestaar

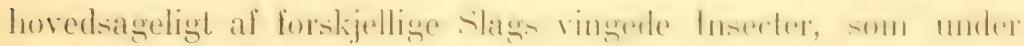
sin Flugt over Vimbllaten filde ned, eller komme demme silit nær; at de kunne naaes af Fisken.

Herunder kunne ogsaa regnes de Masser af Insecter, Lar-

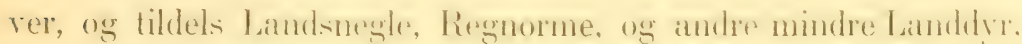

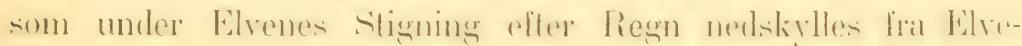
bredderne.

Af saadanne Luftdyr kan undertiden Ventrikelen om Sommeren indeholde 'T'usinder af Individer af en enkelt Art. Saa-

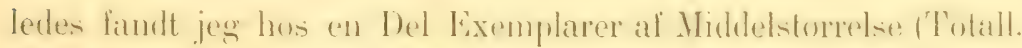

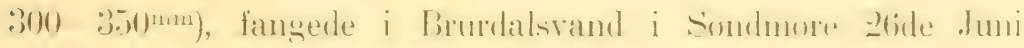

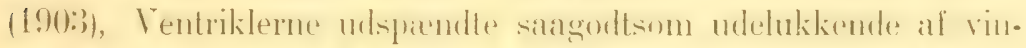

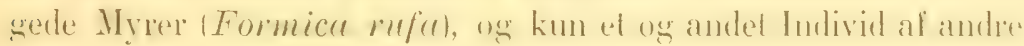
Insect-Arter fandtes blandt disse.

b. Den anden Gruppe er fritsvommende Dyre-Arter, der leve

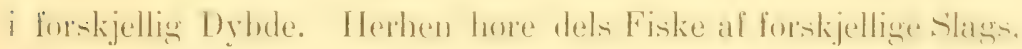
dels mindre Ci'ustaceer, der ofte findes $\mathrm{i}$ saa enorme Masser i

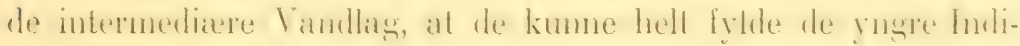
viders Ventrikel. Dette er isaer Tilfaldet i de nogel hoiereliggende Vande.

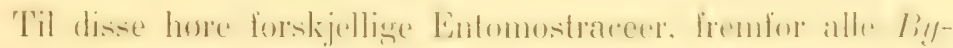
thotophis tomgimmms, dernest bosminn oblusirostris. as Daphinia galeata.

Ethvert storre Individ af Orreten er rede til at sluge de mindre af sanme Art, simt enhver anden Fisk, der naar inden

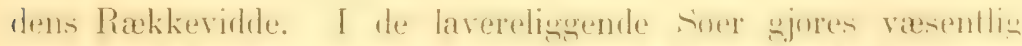

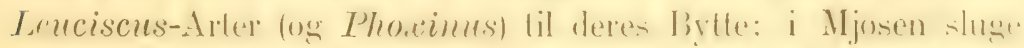
de: store orreter liblels Coregomas lavaretus. Ilas ed Ind., lamenel

\footnotetext{
1 Naturen 1901, p. 176 (Bergen 1901).
}

Vir..Selsk. Forh. 1903. No. 9. 
her 26de O(t. (190:3), og hris Totall. var $590 \mathrm{~mm}$, fandt jeg et Expl. af den sidstnæunte Art med en Totall. af $220 \mathrm{~mm}$.

c. Endelig nærer Ferskvands-Ørreten sig af forskjellige Clag- Drr, der have sit Tilhold paa eller ner Bunden. Herhen lorre forskjullige Snegle og Muslinger, især af Slægten Limnaea, en Del Krehsdyr, isar Gammans pulex, samt tildels InsectLarver; af de sidste ere af Vigtighed Larverne af en Dipter 1. Simulia). som i enorme. Masser forekommer i mange Elve (isar i Fjeldegnene).

Blandt Naringsmidlerne paa Bunden horer ogiaa Fiske. Rogn. Fra Solensoen i Tolgen er det bekjendt, at den indfinder ig paa Harrens Grdepladse. Ligeledes er det et relkjendt Far. tum. at den med Begjærlighed fortarer andre Orreters Rogn (eller sin egen), idet hvert Rogn, som kan naaes eller kommer i Drift fra Grdepladsen, hliver opsnappet af de nedenfor ventende Individer.

Alt efter Localiteten kan hver af disse Grupper Fondemidler have storre eller mindre Betrining. Den Orret-Stamme, der har sit Tilhold i Elve og Bakke (S. eriox, fario) er for en ikke ringe Del henvist til den forste af disse Grupper, og i de fleste Exemplarer her vil under hele Sommeren findes Spor af storre Insecter (isier af Diptera og Hymenoplera); desuden hore handt Elvefiskenes hyppigste Nrering Larver af Phryganeer og diverse andre Insecter, især af Simmlia-Arterne, hris Larver i tusindvis som an lodden Bekladning ere fastede til Stene paa mange Steder i Elvene.

Blandt sjeddnere Crustaceer fra det grunde Vand kan nwenes den meteorisk optradende Phyllopode Lepridums areticus. smn Hr. Initf.-K. enkelte Gange har lundet i Orretens Ventrikel i Fjelwand paa Dovere, og i Bjoreia (paa Hardangervidden).

I de store Indsøer ere Orreterne fornemmelig henviste til de Drreformer, der have Tilhold ved Bunden, eller i de mellemliggende Vamdlag. I Fjeldvandene damer paa flere Steder riammans pulax den orerveiende Del af Nieringen, og dennes Tilstedeverelse betinger her i vatsentlig Grad orretens Qnalitet. ofte are Individerne frldte udelukkende af denne Fode; i rn 


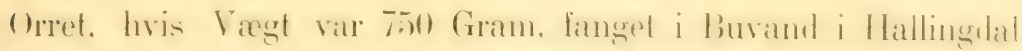

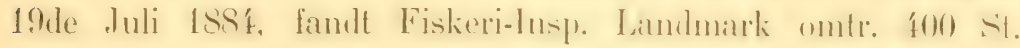

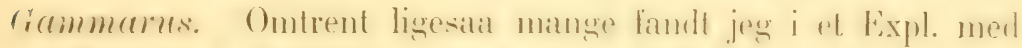

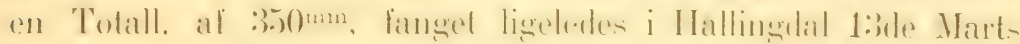
(1903).

I Regelen vil Orretens Ventrikel i alle storre Vande indeholde hovedsagelig Fode fra et enkelt af disse Vandlag.

Hos 20 yngre Individer, fangede i Reinsvand i Ringebo

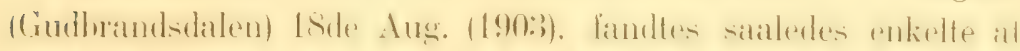

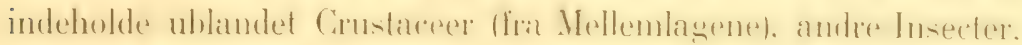
$0 \mathrm{~g}$ et enkelt Ind. alene Mollusker. Crustaceerne bestode af

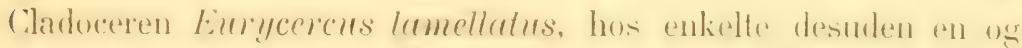
anden fommarus pulex: Inserterne vare vingede. Former al forskjellige (Ordener, der vare faldne tillieldigl i Vander. Lit Ind. indeholdt alene ef Dusin Slo al Tratcata piscimalis, samt en anden Sphcierium.

I mindre Søer og i Elvene vil dog ofte forekomme Prover fra de forskjellige Dybder hos samme Individ.

Abnorme Fodemidler. Under Orretens Næring kan ogsaa indsita smati-Pattedrr, nemlig Leman (L. lemmms). on tildal-

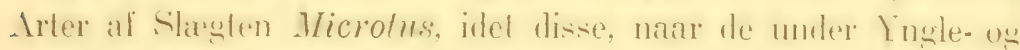
Vandre-Aarene sette over Elve eller Vande, kumne hlive slugte. af de større Orreter.

Saadanne Tilfælde ere kjendte fra de fleste Egne under Leman-Aar. I 1895, da L. lemmus havde Yngle-Aar over en

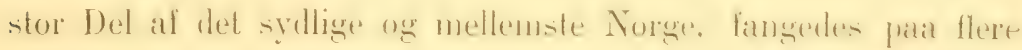
Steder Individer med hele eller delvis fordoiede Leman eller

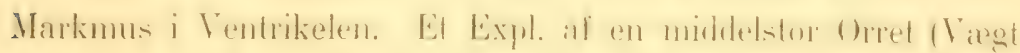
21/2 Kilogr.), fanget i Selbo 16de Aug. 1895, havde saaledes i Ventrikelen 3 friske Lemæn. Et Expl., hvis Vægt var blot 11/2

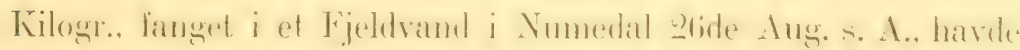
4. nelop slughte Leman i Ventrikelen: ved Hegre (Sinrdalen) fiskedes 15de Aug. (1903) et Expl., hvori 2 Lemæn.

Et stort Ind., fanget i Skogsvand paa Ringerike 16de Oct. 1894, havde i Ventrikelen 2 hele Rana temporaria, en 
Vand-Spidsmus (Neomys fodiens), foruden Rogn af Sik (Coreg. lavaretus).

Ilaarene af disse Smaa-Pattedyr samles efter Fordoielsen i Ventrikelen til langagtige Boller, der sandsynligvis opgylpes ligesom hos Rovfuglene.

Hoide over Havel. Det hoieste Punct i Norge, som vides hehoet af denne Art, er Normanslaagen paa Hardangervidden, hvis Høide over Havet er 1250 Meter.

Store Individer. De storste Individer af Orreter erholdes i Norge i de dyhe Indsøer, især i Tyrifjord og Mjosen.

Den Form, som under Navn af Viul-Ørret stiger op fra Tryrifjorden til Viul-Fossen, angaves ${ }^{1}$ i Midten af 1800-Aarene at have kunnet opnaa en Veegt af omkr. 29 Kilogr. I vor Tid ere Individerne mindre, og naa i denne Su sjelden en Storrelse, som Mljos-()reten. Det storste Individ, som vides langet i Tyrifjorden i desenere Aar, havde en Vaegt af 13 Kilogr.; el andel Individ, der nylig toges i Holsfjorden (11te Aug. 1597), veiede 11 Kilogr. Dette havde en Totall. af $950 \mathrm{~mm}$, og en Omkreds af $570 \mathrm{~mm}$.

Mjøsens store Ørret-Form, der er kjendt under Navn af Hunner-()rret. og som især fanges i Laagens nederste Del (op) til Hunnerfos), samt i den nordlige Halvdel af Mjosen, kan angivelig naa en Viegt af 15-1S Kilogr. Saadanne Individer ere log sjeldue, og $\mathrm{i}$ de seneste 40-50 Aar er neppe noget Expl. linget, hvis Viegt har oversteget 14 Kilogr. Som sierligt stort omlaltes derfor et Expl. fra de senere Aar, fanget i Laagen (i Juli 159.5), der reiede 12,2 Kilogr. Et andet Expl., fanget $i$ Mjusen udenfor Gjovik 2Lde Dec. 1S9S, havde en Veget af 12 Kilogr:

I Kystdistricterne naa Individerne neppe en Storrelse, som de ovennevente fra Landets indre Dele. I Raarand i Maalselvedalen (indenfor' 'Tromso) kan den dog opnaa en Vagt af 9 Kilogr.:

1 Meddelt af afdode Prof. Rasch. 
i Jolstervand (i Sondfjord) erholdtes of (som det ansaates) usidvanlig stort Ind. i Sept. 1897, hvis Vægt var 7,5 Kilogr.

Vener-Lax. Den Form af S. eriox, som under Navn af Vener-Lax befolker Dybderne i Venern, og som i Regelen er omtalt som en relict Form af $S$. salar, stiger fra denne So op

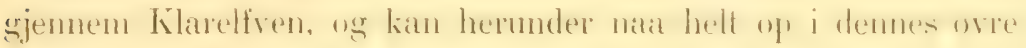
Del i Norge ('Trysil-Elven) for at gyde.

Denne store og temmelig udprægede Ørret-Form, som i Hahitus og andre Charaterer normer sig Laxen, er i Lobet al

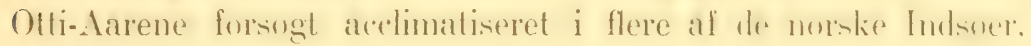
og med tilswneladende Fremgang. I de navole Air ree. ifolger

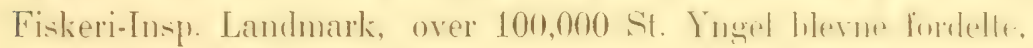
væsentlig i folgende Søer:

Tyrifjorden: Randsfjonden og spirillen: Mjosen med Falkstadely (IIamar) samt Laagen: Gjersjoen i Akershus Amt: rn Del Elve og Vande i Thelemarken: nogie hrierelignende Vande i Gran (Hadeland).

Fra flere af disse Vasdrag opgives det, at Exemplarer, der antages at stamme fra den indinte Ingel. ere erholdte, nghave. bibeholdt Stam-Formens Characterer.

Salmo alpinus, Lin. 1766.

Udbredelse. a) I Landets sydlige og sydvestlige Dele fore-

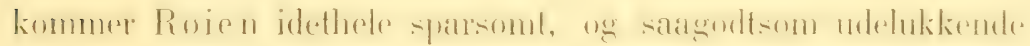
i Indsterne. i Regelen de meget horepeliggendes simt i rejeldvandene, hvor den i flere 'Tilfælde er indfort i Lobet af de sidste 30 Aar. I Elvene forekommer den i disse Dele af Landet yderst sjeldent.

I Saltvand forekommer Roien i disse Landsdele saagodtson aldrig. Et Expl. er omkr. 1860 erhvervet af Prof. Esmark, an-

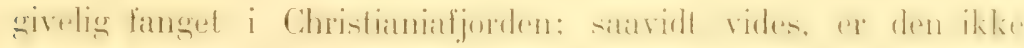
iagttaget her senere. Et Expl. angives endvidere at være fanget udenfor Bergenskysten i Mai 1897. 
h) Fra Nordland og nordover langs Tromso-Kysten fore. kommer Roien baade i Ferskvand og i Soen; den hebor her saavel Elve, som Indsoer, og gaar regelmæssig ud i Havet om Vinteren.

Det sydligste Vasdrag i Landet, hvor Røien vides at gaa regelmæssigt fra Elvene til Soen og tilbage igjen for at gyde, er (ifølge Landmark) Røsaaen i nordre Helgeland.

Nordenfor Helgeland begynder Saltvandsformen at optræde almindeligere, og i de store Vasdrag i Tromso Stift (Salangselv, Maalselv) er den en regelmassig Vandrefisk fra Swen af og langt op i Elvene, ligesom den er talrig i disse Egnes Fjeldvande.

c) I Finmarken er den ligeledes nærmest at betragte som en Saltvandsform, der ligesom So-Orreten stiger fra Havet op i Elvene og Vandene for at gyde. Denue Saltvandsform anlægrger en lys og blank Farve, der ligner Laxens, og næsten er uden spor af Pletter (isar el dette Tilfieldet med de mindre Individer).

I disse Landsidele naar den sjetden nogen betydelig Storrelse, og Individer med storre Vægt end 2 Kilogr. træifes kun undlagelsesvis. I Altevandet, overst i Maalselvens store Vasdrag, skal den (ifolge Sparre-Schneider) dog kunne naa en Viegt af omtr. 6 Kilogr.

So-foimus Treving. Fra Fiskeri-Assistent Melle modtog Chria-Nuseet (Hosten 1903) outrent 50 Ventrikler af Roie, indsamlede pai min Anmodning samme Sommer i Ulfsfjorden og sorfjorden indentor Tromso, dels $\mathrm{i}$ selve som, dels under Opstigningen i det nierliggende Jiegervand og at Par andre Smaivande.

Individerne fra Soen (28de Juli), hvis Totall. var omkring 5y)mm. indeholdt enten Fiske, eller Cirustiteer. Af de forste kunde kjunder Lnger al Sild on al Sil (.lmmodytes). De fleste Ventriklen valre dog fyldte af I'lancton-Cirustaceer, isier Euthemisto librllnder og Boreophansia inermis, horal fornemmelig den sidstnavole Art kunde mblanded folde Ventrikelen. Desuden fandles i mindre Antal Mysis oculnte, hindet med en og anden Strandfisk (Pholis gumnellus). 
Individer, fangede (14de Juli) under Opstigningen i Jægervands-Elven (de fleste yngre med en Totall. af indtil $250 \mathrm{~mm}$ ),

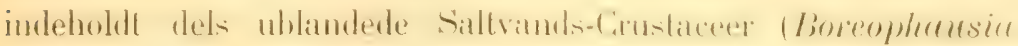
inermis og Gammarus locusta i Hængde, saml en og anden

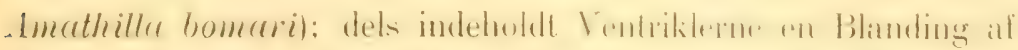

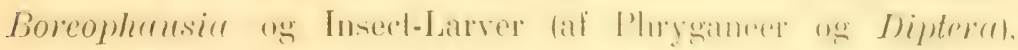

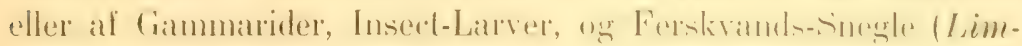
naea ovata).

Individerne fra Ferskvandet (Jægervand Juli-Aug.) inde-

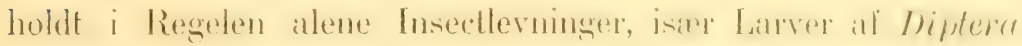
og Phryganeer, simt af Ephemerider. Enkelle Ventrikler rant.

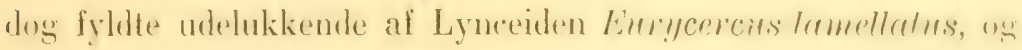
et Par Ind. indeholdt alene Limnaea ovata.

Storrelse. Det storste Ind., som jeg har undersogt fra Norge, modtog Chria.-Mus. fra IFolsfjord (T'yrifjorden), haror det var fanget i Garn paa ringe Dyb 7de Nov. 1900. Dets Vægt var 6,3 Kilogr. Det havde en Totall. af $794^{\mathrm{mm}}$ : Hovedets Latengde. var $198^{\mathrm{mm}}$, Legemets Hoide $220^{\mathrm{mm}}$. I Forhold til Storrelsen var sadedes Individet, (der var en Han). forholdsvis knd ug hovil.

Coregonus lavaretus, Lin. 1766.

Uabredelse. Som de fleste ovrige Ferskvandsliste al osllig Oprindelse har siken (og dens forskjellige Ralcer) i Norge liesentlig ב store Udbrednings-Centrer, uhtenfor hvilke den iklir forekommer.

Det ene af disse omfatter den storste Del af det "ostenfjeldske" Norge, eller Landet sondenfor Dovre, hvor dens Ud-

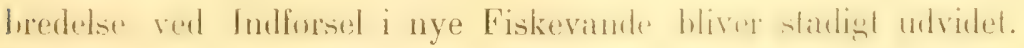
Dog mangler den endnu i hele Bergens Stift.

Det andet er Finmarken, hvor den er talrig $\mathrm{i}$ de fleste Vande og Elve, og hvor den allerede har været omtalt (g.jennem Leem) siden Midten af det 18de Aarbundrede.

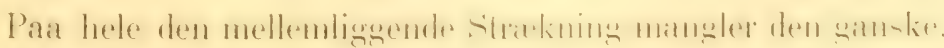
naar undtages, at den forekommer i nogle Smaavande $i$ Liernes Præstegjæld i Trondhjems Stift (ind mod Rigsgrændsen). 
I Saltuand. I Norge er Siken saagodtsom udelukkende bunden til det ferske Vand, og blot paa enkelte Steder er iagttaget en Brakvandsform, der synes at have sit Hoved-Tilhold udenfor Elvemundingerne (f. Ex. ved Fredrikstad), ligeson spredte Individer ere hist og her fundne i ublandet. Saltvand, tilsyneladende forvildede fra nærmeste Elv eller Indsø.

I Dranmensfjorden, der, som hekjendt, danner et lukket Bassin, adskilt fra den ydre Del af Fjorden ved den grunde Tarskel ved Svelvig, synes dog en hel Stamme at have sit. normale Tilhold, og den stiger herfra op i Drammenselven i October for at gyde, ligesom fra en Indsø.

Underarter. Ogsaa i Norge er Siken en polymorph Art, der optrader under en Rakke af Former, der dog indbyrdes ere forbundne ved Mellemformer eller individuelle Variationer. Ofte har den Stamme, som hebor et enkelt Vand eller et begrandset Omraade, et eller andet Sierprieg. hrorved den skiller sig fra nerhoende Stammer, saasom i Storrelse, Legemsform. Snudens Bygning eller ved sin Grdetid. Men at fastswtte skarpe Characterer for alle disse Former lader sig ikke gjemnemfore. Dels ere disse Eiendommeligheder idethele lidet constante, idet hver enkelt Character kan forandres, naar Individerne udsiettes for andre Neringsvilkaar. eller de overflyttes til en anden Localitel; dels we Charatererne ofte hlot fremlradende hos de mere udvilitede Individer, medens Ungformerne flyde over i hinanden ${ }^{1}$.

Nedenfor vil derfor under særskilte Benævnelser blot blive opfort 2 siadame Former, der i Regelen opfattes som de mest

1 Opfatningen af C. lavaretus som en Fielles-Art, der indbefatter i sig flere af de tidligere som distincte Arter beskrevne Former, er allerede antydet af Forf. i 1874. "Under ovenstaaende Navn indbefatter jeg alle de Arter af denne Slagt, som af Prof. Malmgren i 1864 ere beskrevne under Navnene C. Tavaretus, Lin., C. marcena, Bl., og C. widegreni, Malmgr. At de güntherske Arter C.lapponicus og C. gracilis ligeledes ma henfores under samme Hovedart, folger af den samme Opfitning af Artsbegrebet hos denne Slagt, hvis Arter jeg, i Modsætning til de ovennæunte Forfattere, anser i hoi Grad saavel individuelle som locale Tariationer underkastede" (Norges Fiske, Tilliegsh. til Forh. Vid. Selsk. Chria. 187t, p. 166). 
udpragede, skjonl der ogsala imben disie vil kumne funder Individer, der gaa over $\mathrm{i}$ en eller anden at de ovrige Former.

1. C. lavaretus, lavaretus, Lin. 1766.

Denne Form, der danner Artens typiske Stammex, udgjør Hovedmatsen af de Siker, som helon de norke Vatshag. Itoke Artens Tendents til Variation kan ogsila denne Form lettelig deles i Underformer, der med mer eller minder inindialdende Eiendommeligheder tilhore bestemte Localiteter. ligesom dere ogsan inden hver Stamme jevnlig kan parvises individuelle. Uligheder.

Hovedformen er udbredt i de sydlige Dele, saavelsom i

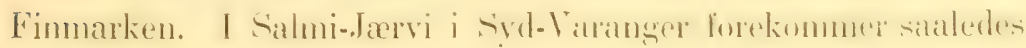
en Form, der $\mathrm{i}$ ingen Henseende alviger fra svollige Individer. I Tama-Elven er denne Sik-Form ligeledes talrign, og af ikke ulutralelig neconomisk Betydning: i Vest-Finmarken er den muligens mere local, og forekommer saaledes i Alten-Elven blot i dennes ovre Dele.

Forplantning. Gydetiden falder regulært i November $0 \mathrm{~g}$ December, men èr iøvrigt efter Localiteten ganske vexlende.

oite er saaledes Grdetiden forskjellig i g norliggende Vande;

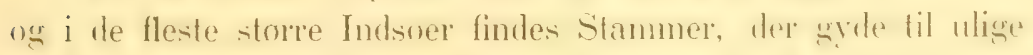
Tider, og som ogsaa $i$ andre Henseender, saasom i Valget af Tilhohksterler, kunue unvise Forskjelligheder. I Kroteren forekommer saledes en Slamme, der (ifolge Fiskeri-[nspr. Lamdmark) regelmasigt gyder i Januar og Fehruar, merlun Hovedmasien gyder fra Midten af November til Midten af December. Den

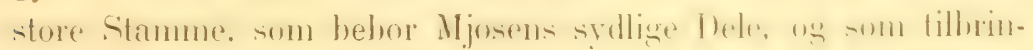
ser sommeren paa de her forekommende store D) Dhler. hiver forst henimod Midten af December forplantningsdygtig, og anger da ned mod Vormens Udloh for al sydis. Den chamme derimud, som forekommer i denne Indsøs nordlige Del, der er grundere,

1 Characteriseret ved sin mer eller mindre hoie Snude, som (seet forfra) danner et tydeligt Qvadrat, samt ved det forholdsvis anbne Gjallegit. ter, hvor 1ste Gjællebue treller 30 Straler, eller mindre. 
og ved Elvenes Indflydelse tidligere synker ned til den lavere Temperatur, som er norlvendig for Arten under dens Gydetid, soger allerede $\mathrm{i}$ Shutningen af September og i Octoher op i Laagens nedre Del for at gyde; denne Stamme naar dog aldrig en rita betydelig Storrelse og Væogt, som den sydlige, der lever under gunstigere Nærings- og Temperaturforholde paa de storre Dybder.

Forle. Demne Art er, ligesom Salmo alpims, vasentlig en Bundfisk. "g henter hovedsagelig sin Fode nær ved eller paa selve Bunden. Deme bestaar derfor af Snegle og andre Mol. lusker, Fiske-Unger, Insert-Larver (især af Myg), samt, for Ungernes Vedkommende, for en hovedsagelig Del af Entomostraceer, der ogsaa leilighedsvis kan findes helt, eller blandet med anden Føde, hos de mere udvoxede.

Som Exempler paa Arten af deres Fode i de forskjellige Landsdele kan anfores følgende.

Af Fiske-Arter har jeg i Ventrikelen fundet Unger af Leuciscus-Arter (Glommen).

Et Ind. fra Orrevand paa Jæderen (24de Aug. 1873) indeholdt en blandet Samling af Bunddyr og Crustaceer, nemlig en Mitsise Insect-Larver, flere smaa Mollusker (Sphaerium, Pisidiuml, samt af Entomostraceer talrige Sida crystallina. Desuden flere Expl. al en i denne So forekommente relict Amphipode (Pontoporeia affinis).

Hus 7 storre lixpl., fangede i llittersjo indenfor Roros lizt. Weter o. II.) I fte Juni (190:3), vare Veutrikterme fuldproppede udelukkende al Ferskvands-Mollusker. Hovedmassen bestod af Plunorlis horealis, hvoraf kunde forekomme flere Hundrede Stykker lus enkelte af Individerne; dernast nogle Limnaen ovata, samt enkelte Sphaerium mammillanum.

Lublex cigdetiden fortares ligeledes i stor Udstrakning Rugn af deres ogen Art. Hos et stort Expl., fanget ved Lillehammer

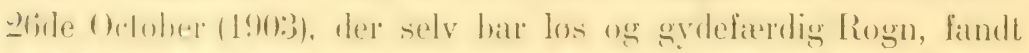

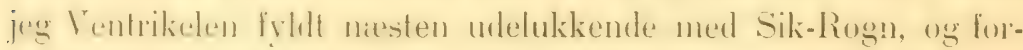
uden denne blot en og anden Unge af en Limnaea. 
Hos Individer fra Finmarken har jeg fundet Foden hos

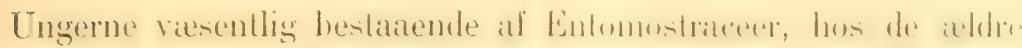
at Snegle.

Hos en Del Unger ('T'otall. S0-100 mm), tagne i Salmi-Jærvi,

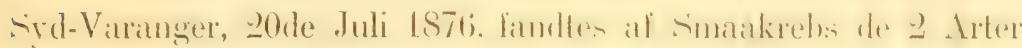

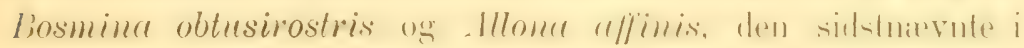
overveiende Antal. Desuden en Del Myggelarver.

Hos Unger af samme Storrelse fra Langfjordvand, Syd-

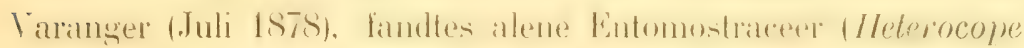

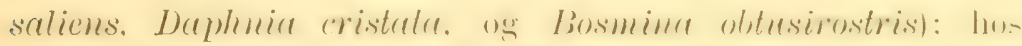

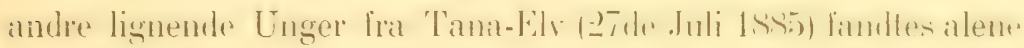
Nyggelarver, men ingen Smaakrebs.

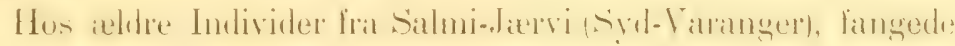
sammen med de ovennævnte Unger 20de Juli 1876, val Ventriklerne fyldte med en Planorbis.

Endelig kan nævnes, at hos et Ind., langet i Saltvand (blandt sild) udentor soon i Christianiafjorden 10de Juni l.s!). indeholdt Ventrikelen ublandet Siltrandsurering, nemlig nogle Unger al Gobius flavescens, samt et Par Gammarus locusta.

Hermaphrodit. Et Ind. med udviklet Rogn og Melke modtog Chria.-Museet i Nov. 1887 fra Ekervandet (mellem Drammen og Kongsberg).

2. C. lavaretus, wartmanni, (Bloch) 1781.

Udbredelse. Denne Race ${ }^{1}$ er mere local, end Hoved-Arten.

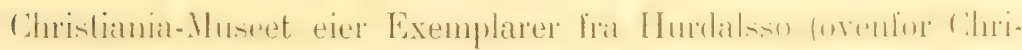
stiania), samt fra Langljordvand i Syd-Varanger (Sept. 187T, Sept. 1883).

Den synes aldrig at opnaa nogen betydelig Storrelse; i Hur-

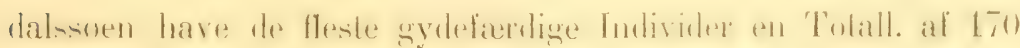

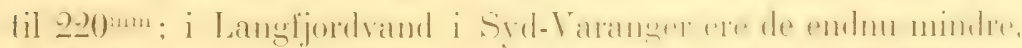

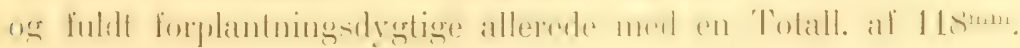

En lavneset Form af ringe Storrelse, hvor Snudens Qvariat er lavt eller næsten utydeligt, og hvor Gjallegitteret samtidigt er mere tæet. straalet, idet 1ste Gjallebue har mere end 30 Straaler. 
Det storite loreliggende Expl. fra denne sidste Localitet har en Totall. af $146^{\mathrm{mm}}$.

I loggge disse Soer forekomme de ved Siden af Hovedformen, men holde sig altid i sarskilte Stimer. I Hurdalssnen har stammen endog sit eget Navn (Sild); dens Gydetid falder her i November og December. I Langljordvand er Gydetiden i Slutningen af September.

Iovrigt er Racen, som ved en flygtigere Betragtning kan strnes udpraget nok ${ }^{1}$, tilhoielig til at flyde over i Hovedarten, naar Livsvilkarene forandres. Saaledes bliver, ifolge Beloernes Udsagn, "Ilurdalsioens Sild til Sik, naar den overfores til andre Vande".

Sandsynligvis forekonmer den samme Dvergform i andre Søer og Elve (især i Finmarken).

Fode. I Overensstemmelse med denne Arts svagere Byg. ning og twtlere Gjwllegitter er Naringen vasentlig mindre Drr, eller det grovere Plancton; specielt kunne enkelte Arter af Entomostraca i enkelte af vore Søer optræde i saa enorme Masser, at Vandet synes næsten tykt (f. Ex. af Bosmina).

Hos Exemplarer fra Langfjordvand i Syd-Varanger, fangede Mnsten 1ss:3 (Totall. omkr. L20 mm), vare saledes Tentriklerne fuldproppede af Entomostraceer, næsten udelukkende Bosmina obtusirostris. (i tusindvis), sant enkelte Daphnia lonupispina.

3. C. lavaretus, oxyrlyynchus, Lin. 1766.

litbredelse. Den spidisinudede Form². Nizh-Siken, der, lige. som de arrige, ved Overgange er forthudet med Hovedtormen. syne idethele at udvikles sparsomt i Norge, og er her videntlig kjendt fra Brakvand. Allerede i Fenti- "ge sexti-Aarene modtog lihria.-Musent Exemplarer fra Elvemundingeme nden-

1 1ste Gjallebue indeholder hos Exemplarer sanvel fra Hurdalsso, som fra Syd-Varanger omkr. 33 Straaler.

2 Kjendelig red den uddragne Snudespids, der rager betydeligt from foran Munden, og ender conisk eller spidst afrundet; Gjællegitteret har, som hos Hovedformen, 30 Straaler (eller mindre) para 1ste Gjollebue. 
for Fredrikstad og Fredrikshald, hvor ogsaa i de senere Aar flere eller færre Individer ere fangede, især om Hosten; den angiver her al slige op i Glommen medentor sarphore for at lege.

Fra andre Localiteter, end de ovennævnte, har jeg hidtil hol seet at enkelt Individ. Dette var hanget verd likekkers unden-

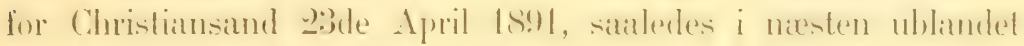
Saltvand (Chria.-Mus.).

Fode. I Ventrikelen af et reldre Ind. fra Glommens Mun-

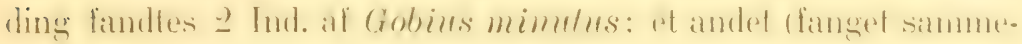

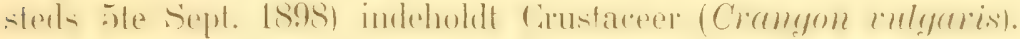

Coregonus albula, Lin. 1766.

Udbredelse. Er i Norge indskrænket til Landets sydostligste Dele, hvor den for Tiden forekommer i 3 hegrændsede Districter, nemlig:

I Mjosen; i forskjellige Soer i Akershus Ant og henimod de:n stenske Cirendire mellem Fredrik-hald og Kongsinger; siml i Tyrifjorden.

1. Fra Mjosen er den omtalt allerede $\mathrm{i}$ de topografiske Skrifter fra Midten af det 1Sde Aarh., og har her altid været kjendt under Navnet Jage-Sild (rettere Latage-sild). Then har her, salurill vibes, allene en enkelt Gydeplads, nemlig i Latagens rillol, ved lillehammer. hor Gidningen forengar i len forste Halvdel af October, (undertiden allerede i de sidste Dage af September).

Under denne Gydetid fanges den i stort Antal i Søens ovre Ende og i Laagens nedre Lob (indtil i omkring 7 Kilometers

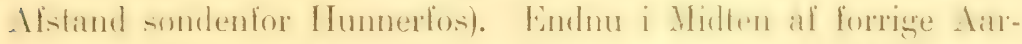
hundrede (i sexti-Aarene) kunde her ophiage- lige til 1000 Tronder aarligt; $i$ de senere Aar er Udbyttet betydeligt mindre.

Et mindre Fiskeri foregaar omkring Helgeøen i Sommermanederne, men dette ophorer i septrmber kot for frotudiden.

2 I I de sydlige Grendsedistricter mod Sverige forekomume den under forkjellige Navne toftest Y emme) i llere Sorer i Mkrr- 
hus ug smatilenenes Amter. Saaledes fundes den i Holangen, i Havsjo, i Vangen, og i Netmangen: alle disse Soer staa i Forhindelse med himanden, og have Udlob, i Sverige. Fremdeles findes den i Floensjo (eller Ulvigsjo) og i Tersjo (i Urskoug), samt i T'unsjo (i Holand), og i Sitten, i Mjwermen, ug i Romsjo (i Romskougen): de sidstnevnte Soer have alle Udloh i FredrikshaldsVasdraget, hvor den ligeledes findes i flere Soer.

3. I Tyrifjorden er Lagesilden, ifolge Fiskeri-Insp. Lantmark, oprindelig indfort (i 1SS3): ligeledes er den (i 1S81) forsogt indfort i Randfjorden, men tilsyneladende uden Fremgans.

Storrelse. Det storste Ind., jeg hidtil har maalt fra Norge,

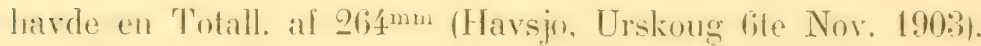

Forplantning. I Soerne $\mathrm{i}$ de sydlige Grændsedistricter falder frydetiden senere, end i Mjosen, eller omkring Beg. af December. I 1857 modtog jeg gydefixdige Individer, fangede i Urskoug fde Dec., og i 1891 en Del fra Aremark, fangede tite Dec., der endnu ikke vare helt udgydte.

Eggenes Antal hos el mesten gydefardigt Individ (Floensis i Urskoug 12te Nov. 190:i) var omtr. 9100 St.: hos et andef (C) demarksjo ltide Nor. 190:3) var Antallet omtr. 9200 St.

Naring. Denne synes for den overveiende Del at bestaa af Entomostraceer. Hos Individer, fingede udenfor Hamar (14de Sept. 1S841, vare Ventriklerne fyldte med Daphnier og Bosmina.

En Del Individer, indsendte til Chria.-Nuseet fra Fluensjo i Irokoug, langede teste Nov. 190:3, havile Tentriklerne fyldte udrlukkende af Timmocalams macmms ${ }^{1}$, af hvilken Art et enkelt (rognspæendt) Individ indeholdt omkr. $2500 \mathrm{St}$.

1 G. O. Sars, An Account of The Crustacea of Norway, Vol. IV, Cope. poda Calanoida, p. 81, (Bergen 1909). Denne mærkelige Calanide, som af enkelte Forfattere ansees som en relict marin Form, er af Prof. Sars fundet tidligere i Soerne Mjosen, Tyrifjord, Randsfjord, Storsjo og Femsjo; sandsynligvis vil den vise sig at have en betydelig videre Udbredelse i Soerne i Landets sydostlige Dele. 
19037. MEDDELELSER OM yoRGES FISKE I AAREXE 18S1-1901. 143

Thymallus thymallus, (Lin.) 1766.

Udbredelse. Har i Norge i det store taget den samme Ud-

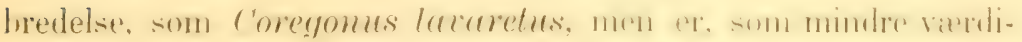
fuld, ikke sa hyppigt som denne overfort til nye Localiteter.

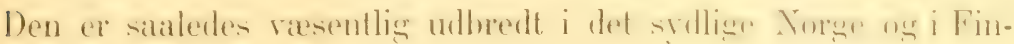
marken; den mangler i Bergens Stift, og forekommer kun paa nogle faa Sterler mellem Trondhjem og Tromso.

1. I det sydlige District forekommer den for 'Tiden alene

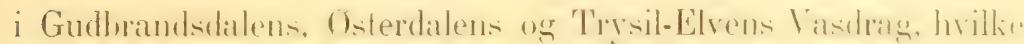

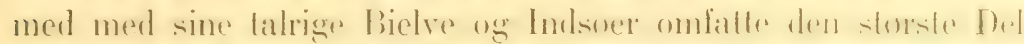

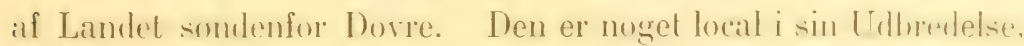
men paia flere steder talrig, og stiger $\mathrm{i}$ en enkell alf Feldwerme

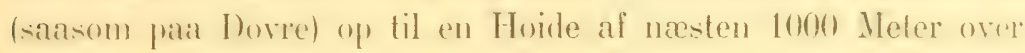
Havet.

Derimod mangler den langs hele Landet. Vestkyst, med den Undlagelse, at den i Rauma. som har Vandforlindelse med Gudbrandsidalens Vasdrag. gaar i Romsdalen ned nasten til Veblungsnæs.

2. Paa Strækningen mellem Trondhjemsfjorden og Fin-

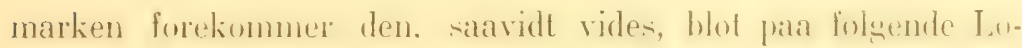
(aliteter:

a. I en Del Vande i Liernes Præstegjæld i nordre Trondhjems Amt (ifolge Landmark: Ringrand. Mururamd. "ge Kiva. sjoen).

b. I Vefsenelv i Nordland, samt i Harvand ved Rigsgrændsen (sparsomt).

c. I Maalselvedalen indenfor Tromso (i Hovedvasdraget).

3. I Finmarken er den atter talrig i Alten-Elv, i Laxelv i Porsanger (saavel i Elven, som i de ovenforliggende Vande),

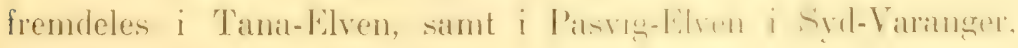
med dens Tillob og Vande.

Ncoring. Denne hentes saavel fra Bunden, som (i stor Ud-

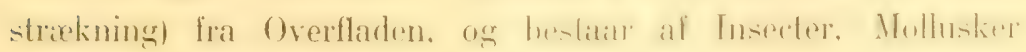
samt tildels Fiskerogn. 
() Sommeren kan Tentrikelen vare fuldproppet af Insecter og deres Larver, og denne Fode violges allerede af de tomme. lange Unger, der herunder vise sig yderst graadige.

Saaledes har jeg hos Ingel-Individer (med en Totall. af $2 \mathrm{~S}$ -30.mm), oplagne i Smaabrkke verl Langfjordvand i Syd-Varanger 1 fte Juli 1S7S. fundet alene Insectlarver, samt en og anden flyvente Hymenopter; tildels vare disie saa store, at en enkelt kunde helt udfylde den lille Ventrikel.

Hos en noget storre Unge (Totall. 5.5m), optaget ved Lillehammer 14de Oet. 1877, fandtes ligeledes blot Dele af LuftInsecter, der tilfeldig vare faldte i Vandet (en Hemipter-Larve, og Dele af Coleoptera).

Et halvroxent Ind. (Totall. $190^{\mathrm{mm}}$ ), optaget ved Hamar 1Sde Juli 1900, indeholdt et broget Selskal, af Luft-Insecter, de fleste endmu hele og ubeskadigete, saa de kunde noiagtigt bestemmes ${ }^{1}$. Disise rare for en overveiende Del Coleoptera, enten StrandInsecter frlirina fossor, Cryptohypuns riparius, sant nogle sman Staphylinider), eller Arter fra Treer, der have hængt ur over Vimdet (Iihagonycha atra og Iih. lestacea, Agriotes obscurus, Orchestes populi, Cassida flaveola, samt en Deronectes). Fremdeles af IIymenoptera et Par Myre-Arter og en Bladhveps, samt enkelte Iniptera og IIemiptera. Endelig et enkelt Brudstykke af en Mollusk-Skal.

Inos 14 Individer, med en Gjennemsnits-Liengde af $270 \mathrm{~mm}$, fangrefle i Sulat-Elve red Folistuen paa Dorre i en Hoide af 940 Meter 0. II. (Aug. 1903), fandtes Foten ligeledes at hestan nesten alene af Insectlevninger. Hos de fleste var T'entrikelen fyldt nasten udelukkende af Dipter-Iarver (Simulier); hos andre var Ifoverhneuglen Luft-Insecter, der tilfieldigvis vare faldne $\mathrm{i}$ Vindet, sabsom Myg og Fluer, Ephemerider, og i mindre Antal Myrer (F: frsco), Blad-Hrepse, Cantharider og Perlider. Sparsommere fandtes forskjellige andre Blat-Insecter (iser Staphylinider os andre Coleopter(t), en og anden Edderkop (Erigone).

\footnotetext{
1 Bestemte af Conserv. Strand.
} 
samt nogle faa virkelige Vand-Insecter, saasom en Agabus, en Haliphs lapponum, og nogle Hydroporus atriceps.

Endelig indeholdt en Del Exemplarer, fangede i Hittersjo ved Roros 14de Juni (1903) Masser af Phrygané-Larver med deres Sandhuse, samt en Del flyvende Insecter.

Hos Ind. fra Finmarken (Klostervand, Pasvigely 10de Juli

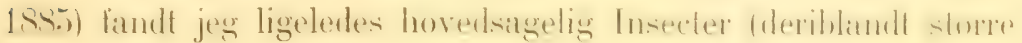
Hymenoptera), men desuden enkelte Limnaeer.

Et Par Individer fra Salmi-Jærvi, Pasvig-Elv (Juli 1876)

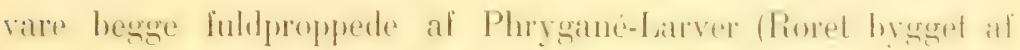
Sand), samt en og anden voxen Phrygané, og en Dipter.

Ligeledes fortæerer den Fiskerogn. En Del Individer, op-

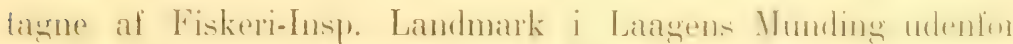
Lillehammer i Oct. 1sit. havde Ventrikleme fyldte af dent metop gydte Rogn af Coregonus albuta.

\section{Osmerus eperlanus, Lin. 1766.}

Udbredelse. Er i Norge en Ferskvandsform, som blot paa et enkell Sted. nemlig i Glommens Munding udenfor Firedriks-and. forekommer normalt i Brakvand; i ublandet Saltvand er den blot fundet i spredte, tilfældigt forvildede Exemplarer.

Den tilhorer alene Indsøerne i Landets sydostlige, lavere Dele, og gaar neppe nordenfor Mjosen. Den mangler overalt

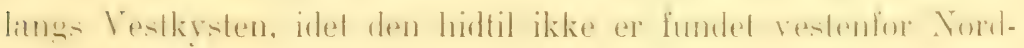
sjo i Skienselven ${ }^{1}$.

I Saltvand ere enkelte Individer fundne i Christianiafjorden,

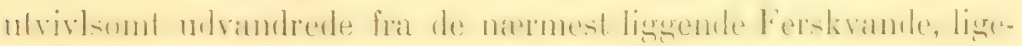
som den er opgivet (af Prof. Rasch) at være fundet i den overste Del af Drammensfjorden.

Dens Navn er hos os Krokle (Mjosen), Nors (Fredriksstad), samt Slom (tlere Steder).

1 I Olsen, "The Piscatorial Atlas" (Grimsby and London 1883) angives denne Art at forekomme langs hele Kysten fra Christiansand af og op til Bergen. Dette er en Feiltagelse; intet Individ vides med Sikkerhed hidtil fundet paa hele denne Strækning.

Vid.-Solsk. Forh, 1903. No,9. 
Storrelse. De fleste hus os forekommende Individer tilhore 'tl mindre Riace, med en gjennemsnitlig Læengde af omkr. $1500^{\mathrm{mm}}$, og i mange af vore Soer synes den aldrig at blive større.

Den storre Form, hvis Totall. er $200^{\mathrm{mm}}$ og derover, optræder idethele sparsomt, og synes ikke at udvikles paa alle Localiteter.

I Mjosen forekommer saaledes enkelte Stammer med en Totall. af omkir. 230 mm; men i Regelen bestaa de store Stimer, nom her i Gydetiden optages para flere Steder i tondevis, udelukliende af den mindre Form. I Mesnavandene ovenfor Lillehammer, hvor den er udsat, har den (ifolge Fiskeri-Insp. Landmark) udviklet sig til en kraftig Form, der er storre, end Gjennemsmits-Individerne (af den mindre Race) i Mjosen, hvorfra den stammer.

Ogsaa fra Fredrikshalds-Vasdraget har Chria. Huseel i de -enere Aar morlaget enkelte af den storre Race fordefierdige Hunner), hvis giennemsnitlige Totall. er $230 \mathrm{~mm}$.

Udenfor Fredriksstad forekommer ligeledes denne større Race i Brakvandet. hwor den fanges i Garn sammen med Torsk. Sild, Ansjos (Clupea sprattus) og Smanflyndrer. Iit Ind. fra denne Localitet havde en Totall. af $240 \mathrm{~mm}, 0 \mathrm{~g}$ er det største, jeg hidtil har undersøgt fra Norge.

Forplantning. I Mjøsen gyder den i Lobet af Mai, den storre hiare (ifolge Iagttagelser af Fiskeri-Assist. H.-Kaas) noget tidligere. end den mindre. I Fredrikshalds-sinerne falder Gydetiden ligeledes i Mai.

Ncering. Hos Unger med en 'Totall. af omkr. $70^{\mathrm{mm}}$, oplitgne ved Lillehammer Sde Oct. 1900. vare Ventriklerne fyldte

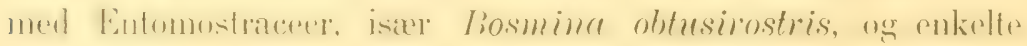
Cyclops.

Hos en 'Del større Brakvands-Individer', fangede udenfor'

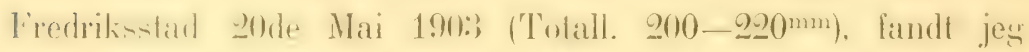

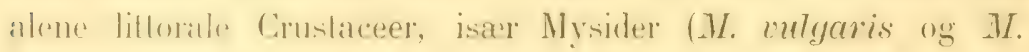
inermis), simb enkelte Amphipoler (Corophimm longicone ow Gammamis locusta). 
Mallotus villosus, (Müll.) 1776 .

Uabredelse. Lodden har sit Hovedtilhold i Ishavet, og søger herfra i enorme Stimer ind under Norges Kyster i Vaarmaanederne for at gyde ${ }^{1}$.

Disse Indsig mod Kysten have dog altid været noget usikre,

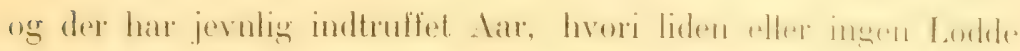
har været sporet, men hvor Gydningen maa antages at have

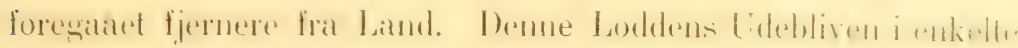
eller i flere Aar ad Gangen har været kjendt og omtalt af flere Forfittere allerede i 1700 -Aarene, ligesom der ogsaia i forrig. Aarhundrede har indtruffet Perioder paa 20 Aar eller mere, hvori deres Besøg er helt eller næsten ganske urleblevet.

Indsigene mod Gydepladsene finde Sted paa mere eller mindre sammenhangende Dele af Kysten lige fri Varangerfjorden af og ned til Lofotens Yiderside, men i storst Autal og mes regelmæssigt langs Kysterne af Finmarken.

Allerede langs Tromsøkysten vise Stimerne sig mere spredt "g uregelmassigt; langs. Nordlands-Kysten indlinde de sig paia enkelte steder anrligt, men sjellen i noget storme Antil. skjonl de ogsaa her kunne være tilstede i saa store Masser, at de kunne "oses op af Havet". Et aarligt Indsig pleier saaledes

1 De nedenfor givne Meddelelser om Loddens Levesæt og Optreden ved de norske Kyster ere grundede dels paa de Iagttagelser, som jeg under gjentagne Ophold i Finmarken har havt Anledning til at anstille, samt de Lrfaringer, som herunder have kunnet indhentes hos oplyste Fiskere og Fangstmand; dels ere de fremkomne i forskjellige af de nyere Skrifter og Afhandlinger, der have behandlet Lodden og Loddefiskeriet. Af disse Skrifter kunne sarligt nærnes:

G. O. Sars, Indberetn. til Dept. for det Indre om ... praktisk-videnskab. Undersogelser over Loddefisket ved Finmarken (Chria. 1879). (Juel), Indstilling . . . . Forslag til Lov om Hvalfingsten i Finmarkens og Tromso Amter (Chria. 1890).

Johan Hjort, Fiskeri og Hvalfangst i Det Nordlige Norge (p. 63). Bergen 1902.

Vor Kundskab om denne Arts Biologi er dog idethele endnu mangelfuld, og flere Afsnit af dens Livshistorie, selv under den Tid, da den staar under vore Kyster, ere endnu lidet kjendte. 
at finde Sted i Saltenfjord (under Polarkredsen), hvor de forrette sin Leg udenfor $(\mathrm{g}$ i) Mundingen af Saltdalselven.

somlenfor Polarcirkelen ere dens Besog mere uregelmassige; dug indfinder den sig nesten hvert Aar i enkelte af de storre Fjorde i Nordland. saasom i Ranen, og den kan her i enkelte Aar fanges i ikke ringe Antal (se p. 160).

I 'Trondhjemsfjorden forekommer den i visse Aar talrigt, og den angaves at have havt Legeplads ulenfor Vardalselven, indtil det store Jordskred i Værdalen indtraf i Mai 1893.

Ferl Landerts Sydliyst. Udenfor Bergenskysten er Lodden idethele at betragte som sparsom, skjont den undertiden fsitarom i $1 S \bar{Z}(0)$ ugraa her paa flere Steder har vist sig i hele Stimer lige ned til Haugesund udenfor: Stavanger.

Mllerede i Midten af det 1side Aarh. (1762) omtaler Strom, at den trefles fra og til udenfor sondmores Kyster; han angiver, at Fikkere paa Storegren ikke sjelden finde den i l'en-

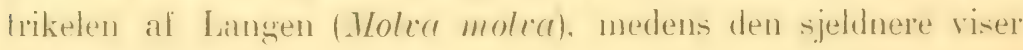
sig under Land.

Et og andet Ind. erholdes dog endnu fra og til paa FiskeLorvet i Bergen; et saadant, der var fanget paa Havnen lode April 189', holdtes en Tid levende i Apvariet paa Biologisi viation i Bergen. Dette var et yngre Individ (Tolall. 14.5.1mu).

Østenfor Lindesnæs kan den ansees som en blot tilfældig Cijaz-t. I Christianiafjorden hev i Sexti-Aarene enkelte Individer fundne, der af Prof. Limark erhervedes for Chria.-Museet. I de senere Aar vides den blot en Gang at have forekommet; den fde Mai 1s86 fandt jeg paa Fisketorvet et udvoxet HanIndivid, fangel samme Dag i Garn (blandt smansild) i Bundefjorden lige udenfor Christiania (Chria.-Mus.).

Tilhold i Ishuret. Den Lodde-Stamme, der besoger Norges Kreler for Forplantningens Skyth i Vaarmanederne. har i den orrige bet af lare sit Tilhold i de tilgrandsemde Dele af Ishavel, hrol dens opholdsited er afhengig af de IIavitromme. fug deres Trmpreratur), der fore de Plancton-Organismer med sign, som paa denne Tid udgjøre deres Fode. 
Dens Hovedtilhold om Sommeren synes derfor især at være

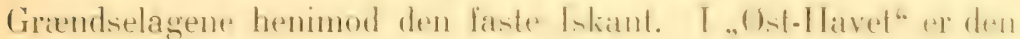
saaledes paa denne Aarstid al Fangimaxul truffet i stole Mats-

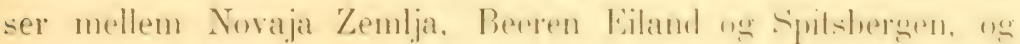

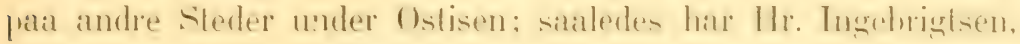
der $\mathrm{i}$ en Aarrokke har drevet Hvalfangst mellem Norge og

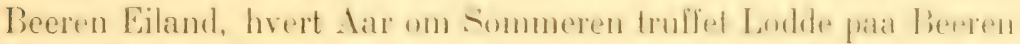
Filand-Banken, ligesom andre Fangulmand have lundef dem i August og September op under Spitsbergen.

Især synes Lodden at være aarvis om Sommeren paa Beeren Eiland-Banken (Bjorno-Iawet). Her kunne Fan-tunkmlene ; Midten af August treffe store Stimer af dels fuhdoxen, dels

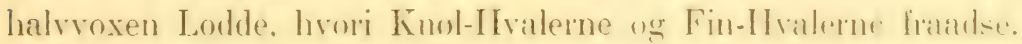
De sines her isor at have sit Tilhold i Bankernes Vilorkanter paa en Dybde, der kan variere mellem so til tso Meter. og hror Vandets Temperatur er mellem 1 og $2^{\circ} \mathrm{C}$.

I Juli 1901 traf ogsaa Dr. Hjort (under "Michael Sars"6 Qdet Togt) Lodde i Mangde i den Torke, der fiskeden i Eggen af denne sirlstnæv'nte Banke. $\mathrm{Og}$ han udtaler derfor ${ }^{1}$ som sandsvnligt, at dens Udbredelse idethele vil vexle med Isgraxulserne. „Naar i.sbaltet on vinteren trækker sig sammen mod Fimmirken. vil ogsaa lodden nærme sig dennes kyster. I aarets forste maaneder finder man den $\mathrm{i}$ havet mellem isen og land, de samler sig da til valdige stimer, som, idet de passerer havel. ligesom samler op alt, hvad der findes af storre hevergelige dy og forer dem alle mod kysten."

Loddens Fiender. Disse Drreformer (.. Brug."I. dee ledsilge Loddestimerne for at fraadse $\mathrm{i}$ deres Masser, ere væsentlig store Fuglesvarme. bestaaende iswer af liksar tridactyla og forskjellige Lams-Arter. (deriblandt den hwidvingede $I$. glancus). fremdeles Fulmarus glacialis. Somateria spectabilis, Liva arra, og andre. De fleste af disse klække ikke ved Norges Kyster, men trekke atter on summen ved Loddens lisig lilbage til Ishavets Der.

${ }^{1}$ Hjort, Fiskeri og Hvalfangst i Det Nordlige Norge, p. 65 (Bergen 1902). 
Af Fiske folges Stimerne fremfor alt af Lodde-Torsken, samt vardige Massere af IIrse (roudus aeglefinus): fremdeles af Hatkiarring fismmiosus microcephalus) og andre Dybvandsfurmer. der mer aller mindre directe folge Loddens Indsig, og

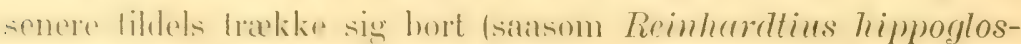
soides. Lyfoodes esmartii. Anarhichas latifrons on A. minor).

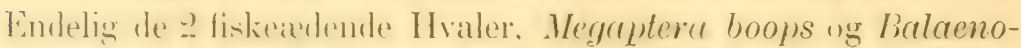
hera physulus. samt flere J)elphiner (isier Lagenorhynchus albirostris): den lidligate af Hvalerne er Knolhvalen (Megaptrert). der indfinder sig med de forste Loddestimer allerede i Marts, men forsvinder igjen i April.

somdenfor Finmarken er dette Brug mindre fremtredende.

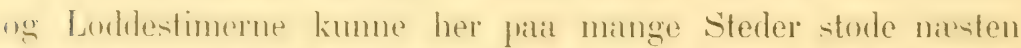

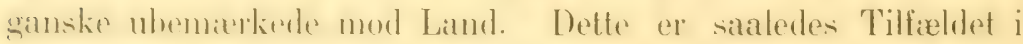
Nordland-fjortene: saavel i Ranenlford. som i Vefsenfjord sker

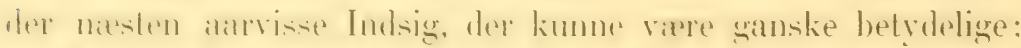
men de bagldages idethede sjedtent. for de ere natade lige ind i Fondlumden. Londe findes her sjeldent eller aldrig i Fiskesmaverne, og Indsiget ledsages lidet af Fiskestimer.

Indsiget kan finde sted pai nesten enhrer Del af FinmarksKysten, men er intetsteds anrist, skjont risse Dele hesoges mere regelmæssigt end andre.

I milde Aar, hvori Golfstrommen virker kraftigere, og Isstimulion ligger lirnger mod (1). vente Fiskerne som Regel stimerie ind moler (1)-Finmarken (og Murman-Kysten): Ind-

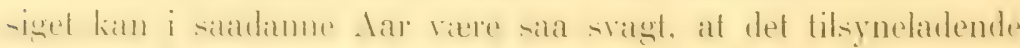
ikke engang berorer Kysten.

Er Aaret koldt, og Isgrændsen ligger Norge nærmere, kan

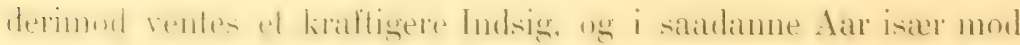
Vest-Finmarken. Saaledes har det altid vist sig, at de storste

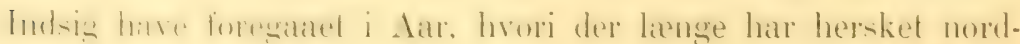

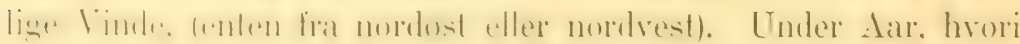
der om Vinteren viser sig Rækved (drivende Træstammer fra Ost), pleie saaledes Fiskerne at vente et godt Lodde-Indsig. 
Men disse Strom- og 'Temperaturforholde, hvoraf Indsiget i Hovedsagen er afhængigt, have dog endnu ikke været Gjenstand for noiagtige Undersogelser.

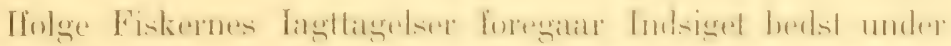

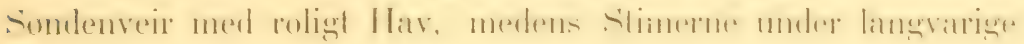
nordlige Storme vente længere med at soge under Land.

Under særligt rige Indsig kunne Masserne være spredte i

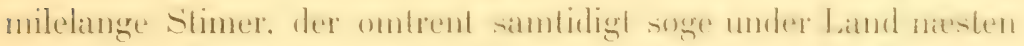

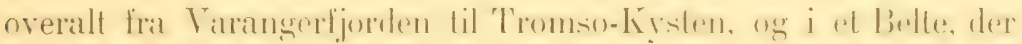
kan have mangfoldige Miles liredele. Men detle hasuder idtet-

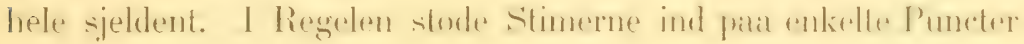
eller mindre Dele af Kysten, og udeblive fra andre. Det har saaledes oftest vist sig, at naar den optræeder i Masser paa Finmark-kysten motenfor Nordeap, har den kun sparsomi indfundet sig i Vest-Finmarken, og omvendt.

Enkelte Aar kunne, som ovenfor næunt, deres Besøg være

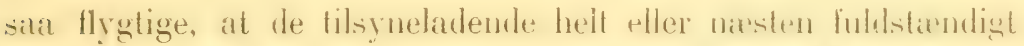

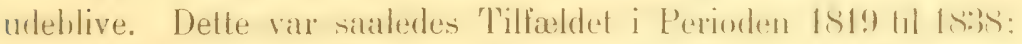

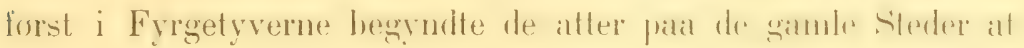
blive aarvisse.

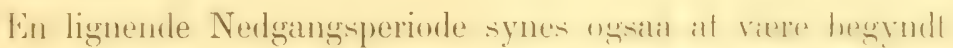
red Aarhundredets Udgang. Lige fra Slutningen al Nitli-Aitrent.

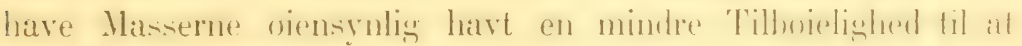
komme op under Land, end tidligere: Gydningen formatar ofte

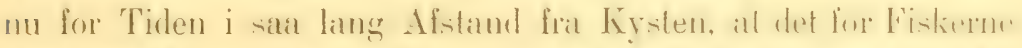
kan viere forbundet med Vanskelighed at finde dems. "se tur-kalle

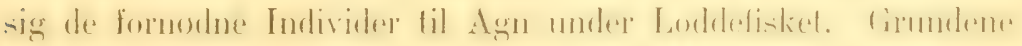

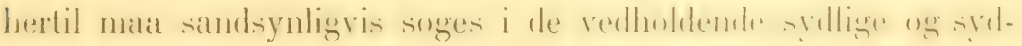
vestlige Vinde, som have været fremherskende om Vinteren i Finmarken i de senere Aar, og som have holdt Lodden under

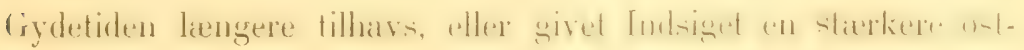
lig Retning.

Stimerne kunne bestaa udelukkende af det ene Kjon, især i

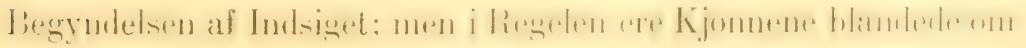
hinanden, saaledes at der i en Stime snart er flest Hanner, suart 
llest Humner. De forste Stimer indeholde ofte blot Han-Lodde ${ }^{1}$; red Udsiget forsvinde ogsaa i Regelen Han-Lodderne tidligere, end Hunnerne.

Da Indsiget sker i flere Repriser, kan det vedvare i flere Mataneder, og nye Indsig kunne vise sig endnu i Juni. Ifolge Capt. Juels Undersugelser stodte Lodden i 1880, (der i Vest-Finmarken var et rigt Aar), under Land ved Gjæsvær i 7 forskjellige Repriser.

Under Indsiget gaar ofte Lodden i tætte Stimer i de ovre Vandlag, og kan herunder undertiden presses saa tæet sammen, at de kumne uses op af Havet med en Hov. Ogsaa hvor Stimerne jages af Hval eller Spækhugger, kunne de danne saa tæette Masser, at de lofte sig op i Vandskorpen, saaledes at Aarer og lignende kunne flyde paa dem. Hvor Hvalerne boltre sig i Lodde-Stimerne, sees ofte Masserne at valte sig ned over Hvalens Ryg, naar denne hæver sig op over Vandet.

Af Fiskerne hetragtes idethele Ivalen som en værdifuld Assistent, idet disse undertiden, naar de staa under Land, kunne drive en eller anden Lodde-Stime foran sig med saadan Voldsomhed, at denne presses lige op i Stranden; her blive de et let Bytte for Fiskerne, for hvem de ere den værdifuldeste af al Agn under det paagaaende Torskefiske (Loddefisket).

riydetid. De forst ankomne Stimer gyde i Finmarken allerede i April eller Begyndelsen af Mai, de senere endnu i hele Juni. I 1S79 traf Prof. Sars allerede udgydte Expl. ved Vard" den ste Mai. Men undertiden træffes endnu i de forste Dage af Juli i Varangerfjorden Smaastimer eller unkelte Individer af IIan-Lodde, som endnu ikke have af.sluttet sin Leg, ligesom der fra on til par demne Tid fanges Torske. i hvis Tentrikel findes Lodde, der endnu bærer paa sine Rogn.

Gydningen. Ere stimerne naaede under Land, hevinge de -ig gjerne langs dette for at soge de gunstige Gydepladse. Disse

IIan-Lorden kialdes i Fimmarlien Fakse-lodde, Ilumnen Rogn-Lodale eller Sil-Lodde (efter Fisken Ammodytes). 
ere oftest beliggende i Bugter og Fingle, og kimne vexle fra . Aar til andet. Enkelte Puncter ere dog aarvisse, og opsoges altid,

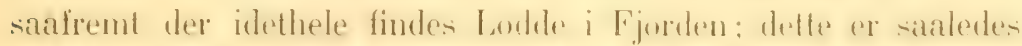
i Varangerfjorden Tilfelded udenfor Mundingen af (Grendse)Jacohselven.

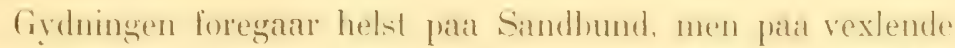
Dyb; undertiden kastes liognen pata el Dybu at hlot nogle: fai Favne, og Fiskerne patastaia da, al ... Timerne ere drevne derind af Hrale1.". I Regelen gyder den dog paa de noged storre Dyb. indtil 40-50 Favne (70-90 Meter).

De Loddestimer, der søge ind mod Grundene for at gyde, ere dog idethele kun en ringe Brokdel nond de Masser, der grde paa det dybere Vand, og her forblive mere eller mindre ubemærkede.

Hvor stort dette Dyb kan være, er endnu ukjendt. En Fangstmand iagltog (1902). at Lodden, der i Marts var kommen i Masse under Land, after forsvandt efter kort 'T'id, og senere holdt sig haardnakket flere Nile fra Land, hvor Dybden var umtr. 220 Neter; her, hvor ingen Hval kunde naa dem, holdt Torskemasserne til, og her antoges ogsaa hydningen at have foregaaet.

Eggene ere forholdsris store, rodgule af linve, og have en Diameler af omkr. $1^{\mathrm{mm}}$.

Rognmængden er noget varierende efter Storrelsen. Hos middelstore Exemplarer er den fra 7000 til omkr. 10,000 St..

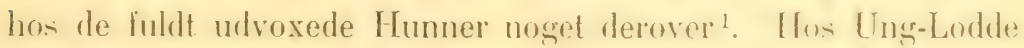
er den betydeligt mindre.

Hos et Ind. fra Vardo af Middelstorrelse, fanget i April 15i:, hvor hele Rognmengden ulvivlomm var i Behold, viste Antallet sig at være 7300 St.

Hos 3 Individer af ulige Storrelse, fangede ved Mehavn (Ost-Finmarken) i Mai 1903, var Antallet folgende:

1. Prof. Lilljeborg angiver Antallet af Rogn til 30-40,000 (Fiskarne, 2dra Delen, p. 660). 
Totall. $126^{\mathrm{mm}}$, Antallet 2696 St.

Totall. 152mm, Antallet 10,038 St.

'Totall. $170^{\mathrm{mm}}$, Antallet 13,363 St.

Eggene synke tilbumds, ligesom Melken, og her foregaar unsaa Befrugtuingen. Rognen fiester sig (ligesom hos Silden) til Bunden, og kan bediekle deme med et tykt Lag; ved Paalandsvind skrfles ofte store Masser i Land, der ligge og raadne i Stranden.

Yngel. Den nyklækkede Yngel iagttoges i store Masser forste Gang af Prof. Sar's ved Vadso 17de Juni 1879. Denne havde en nu Totall. af $S-10^{\mathrm{mm}}$, var glasklar, og havde sit Tilhold i Vandskorpen, hvor den var vanskelig at opdage.

Senere paa Sommeren gjenlandtes denne spiede Ingel i enorme Masser sammen med Thysanoporlerne („Kril“) og andre Plancton-Organismer over Seigrundene, hvor de kunde udgjore Seiens fornemste Niering: deres Læugde var da næsten 1 Tomme (omkr. 23m $)$.

Unger. Den noget større Yngel fandt jeg allerede i Juli LAT under et ophold i Porsangerfjorden i store Masser i Seiens og Torskens Ventrikler; og jeg antog derior, ,at Loddens Yngel i sine første Perioder driver om stimevis i de ovre Vandlag i F jordene, hwor de paa Grund af sit fuldkomme transparente Leseme undgata Opmierkismuheden"1. De mindste af disse Unger

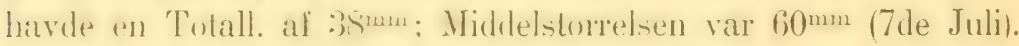

Alle disise vare Aars-Yngel, de shrste udklekkede af lidlige Kuld i April eller Mai, og saledes omkr. :3 Maaneder gamle. The havile enduu huldkommen lingelens ydre Charaterer, med det weromdentlig smale on spinkle Legeme, der nesten er uden Pigment.

Fomben den wennevole Aars- Yngel fandt jeg i Porsanger-

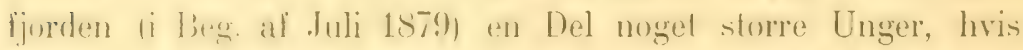
Totall. var onkring $100^{m m}$, og sandsynligris vare 1 Aar gamle.

: Forh. Vid. Selsk. Chria. 1879, No. 1, p. 87. 


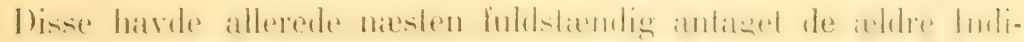
viders Legemsforhold.

Sandsynligvis tilbringe saaledes Lodde-Ungerne hele det forste Aar i Fjordene eller i Kystens Narhed, og begive sig

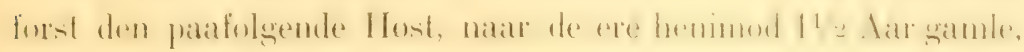
ud paa Havet; i Løbet af Vinteren opnaa de derelter Kjons.

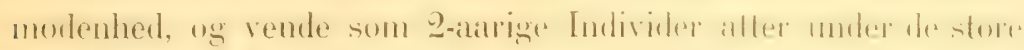
Indsig tilbage mod Land for at gyde.

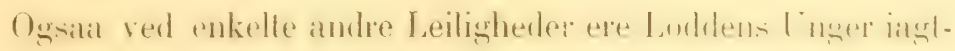
tagne ved vore Kyster. En Unge med en 'Totall. af $65^{\mathrm{mm}}$ optoges af Dr. Hjort under „Michael Sars" 2det 'I'ugt Sde Juni

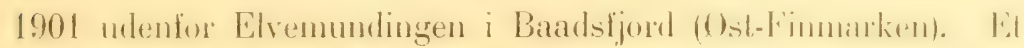

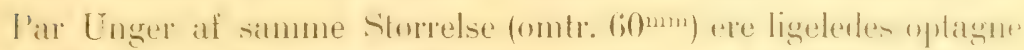
at K. Dahl i Trondhjemsfjorden lved Inderoens i Mirllen al Norember 1sos; ogsa disse sidste have lilhort darels Kuld, mon -andsynligvis varet udklakkede al sildige Kuld om Sommeren.

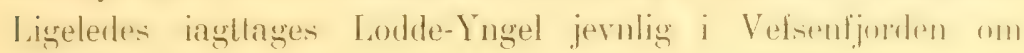
Sommelen.

I Ventrikelen af en So-Orret (S. eriox, trutt $\iota)$, fanget i Bals-

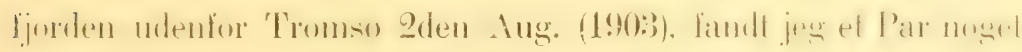
storre Lodde-Unger', hvis 'Totall. var $90 \mathrm{~mm}$.

Dodelighed. Saasnart Lodden har gydt, synes enorme

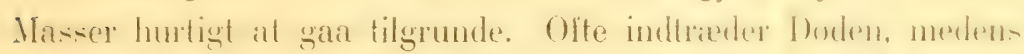

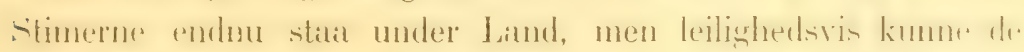

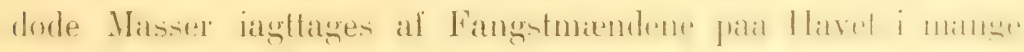
Miles Afstand fra Kysten.

De døende Individer sees herunder at skyde op mod Overfladen og gjore her nogle uregelmassige Svingninger; berores de, soge de atter at trange ned i Dybet, men flyde atter op, falde snart om med Bugen i Veiret, og do. En tidlang bliver

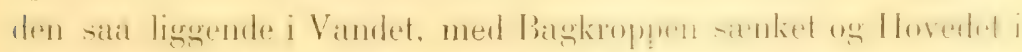

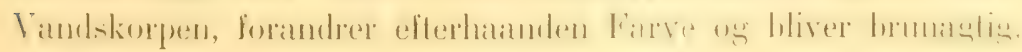
og synker.

Hovedmassen af de dode Individer angives at være Hanner, men der forekommer ogsaa, skjont sjeldnere, dode Humner. 
Den dode Lodde vrages af Hvaler, af Fisk og Fugl. Selv den gratalige Larus glancus prover den flere Gange, hæver sig i Luften med den, slipper den atter, gjor flere Forsog, inden den lader den ligge, og flyver bort. Selv til Agn er den utjenlig.

Denne Dodelighed indtreffer vistnok efter hver Gydning, skjont den ikke altid iagttages; kun i visse Aar fore Havstrommene de dorle Individer op mod Overfladen. eller under Land, "g defte kan vare Grunden til, at der undertiden kan gaa flerè Aar hen, uden at nogen Dodelighed spores af Fiskerne.

Ved Paalands-Strom ere ofte saa store Masser af disse dorde Lodder drevne ind mod Land, at de have "ligget i hele Bjerge i Fjieren og raadnet", og de have $\mathrm{i}$ Sren ligesom dannet en flydende Bro over lange Strækninger.

Saaledes iagttoges i Marts og April 1888 udenfor Vest-Finmarken dord Lodde i saa enormt Antal lige fra Sorvær og op forli Nordcap, at de kunde regnes i Tusinder af Tonder. I 1897 traf Fangstmendene dod Lodde i ligesaa colossale Masiser flydende paa Ilavet omtrent 50 Kilometer af Land udenfor OstFinmarken.

Mulıgens det er de 3-arrige Individer, som nu normalt afslutte sin Livsvandring, medens Resten af de gydende Individer ere 2-aarige.

I'cesen. Af Naturel er Lodden lidet sky, og lader sig med Lethed fange, naar den hevinger sig saa hoit $\mathrm{j}$ Vandet, at den kan naaes. Naur den trekker mod Land, kan intet standse den; den hindres ikke ved Blod eller Affald fra HvalfangerElablissementerne, men svommer ofte om $\mathrm{i}$ det urene Vand lige udenfor disse.

Fre Stimerne nogenlunde tætle, lade Individerne sig let ose "I af Vindet med on Hov, og de vise i Regelen ingen sardeles Frygl for deres talrige Fiender. Den Rovfisk, der ved sine voldsomme Bevegelser leftest er istand til at splitte Stimerne, er Seien.

Den synes idethele (under Gydetiden) at vare temmelig dorsk, ug urviser sjedten livlige hevegelser. I Regelen driver den sagtelig med Strommen: under Liksiget gaar den dog noget hurtigere, 
omtrent med samme Fart, som en liden Baad ror, eller omkring et Par Mile i Dognet.

Paa Grund af dens eiendommelige Lugt, der noget minder om Lugten af Osmerus eperlamus, benyltes den hos os ikke

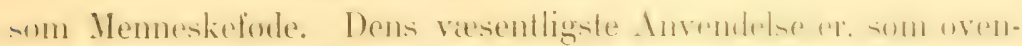
for nævnt, som Agn under Torske- („Lodde-“) Fiskeriet.

Enkelte Fiskere have gjort den Erlaring, at 'Torsk, der om

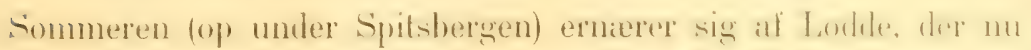

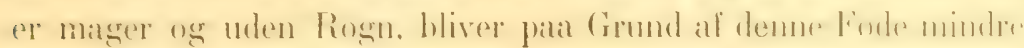
værdifuld som Handelsvare ${ }^{1}$.

Efter Doden udvikler den et seigt Slim, der bevirker, al flere Han-Individer kumne harnge sammen ...efter Taxel. aller den lodne Sidekjol.

Fode. Som Regel tager Lodden ikke synderlig Fode til sig under Gydeperioden. Hos de Individer, hvor Rester af Foden har kumnet parvises, har deme hoved-agelig bestated af prelagiske Smaadrr. Saaledes indeholdt Ventriklerne al en Del Tndivider, som af Prof. Sars undersogtes ved Vardo Vaaren 1879, viesentlig Hyperier (II. oblicia), Calaniter, pelagiske ()rme (Sugritter), og enkelte af de forholdsvis store Boreophansin inermis

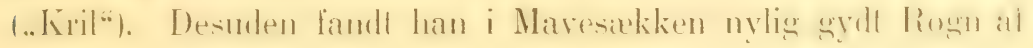
Lodden.

Hos et. Par ligeledes gydefærdige Individer, fangede ved Mehavn (i Ost-Finmarken) i Mai 1903, fandt jeg ligeledes

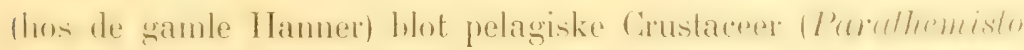

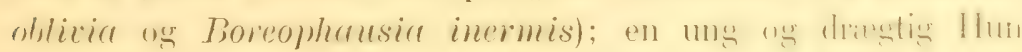
indeholdt foruden de ovennævnte Crustaceer tillige Rogn af Lodden.

Hos et Par Hanner, indsendte til Chria.-Museet fra Komag-

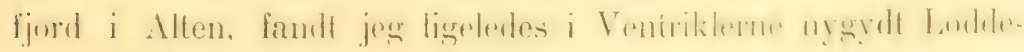
rogn (blandet med lidt Grus fra Bunden); hos det ene Expl. desuden et Par Expl. af Calanus finmarchicus².

1 Meddelt af P. MI. Skancke (Mehavn).

"Hos et yngre Expl. fra Lyngenfjord Juni 1898 var hele Ventrikelen opfyldt af 6 Cestoder. 
Hos en halvvoxen Unge med en Totall. af $90^{\mathrm{mm}}$, udtagen (rom ovenfor nievnt) af Tentrikelen af en Su-Ørrel (S. eriox, trutta), der var fanget i Balsfjorden indenfor Tromss Qden Ang. (1!103), var ligeledes Mavesakken fyldt med PlanctonCalanider.

Ldsiget. Efterhanden som Stimerne have endt sin Gydning. suge de atter tilhavs. fulgt af Torske-stimerne og de nvige Dyrearter, som fremdeles fraadse i deres Masser.

Den Retning, som de udsigende Stimer tage, antages i Hovednagen at viere afhængig af de paa demne Aarstid herskende Havstromme. og disces Indhold af Niering (Aate). I Regelen ville derfor Stimerne komme til at tage en nordostlig Retning. og Lordens Aarsiandringer ville saaledes. $\mathrm{i}$ det store taget. danne nærmest et Kredslob.

Ognia under disse Udsig kumne de leilighedsvis traffes i enorme Masser. En Fisker har i Juni og Juli seet de udsigende Loddestimer "saa trotle. at de har staaet og kogt fra Stranden indtil omkring 20 Mile af Land"1.

Fjord-Lodde. I de fleste større Finmarks- eller TromsoFijorde, eller i de udenfor liggende sunde, vil der hele Aaret kumne findes smaa Stammer af Lodde, hwori Individerne ere s.jennemganende mindre, end den axgle Har-Lodde, og som synes her helt stationære.

Disse Ludite-stammer synes at streife frem og tilhage, ofte i Selskab med Smatisilden, og kunne tildels om Vaaren træffes i Codsig mod llavel; de ere g.jennemgitiende magre, i Regelen ikke forplantningolygtige, skjont der delvis treffer Stmer af

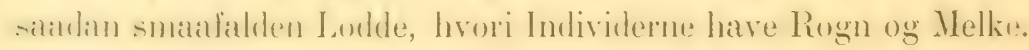
Fiskerte kilde disse: Ludder. der olte viser sig paa Gydepladseme blandt den ixgle Hay-Lodde, las-Lodde, men finde dem losere og mindre tjenlig til Agn, end denne.

Af et Loddestime, der optoges i Tromsosundet 23de Mai ISS1, havde sialedes Hannerne en Laengde of $10 \mathrm{~S}-1 \mathrm{t}^{\mathrm{mm}}$.

' (Juel), Indstill. og Forslag ... Afgivne Forklaringer, p. 55 (Chria. 1890). 
Hunnerne, der allerede var rognfyldte, en Længde af blot $15-1: 30^{\mathrm{mm}}$.

Ligeledes har Capt. Juel i Maven paa en Sei, fanget i

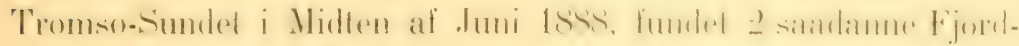

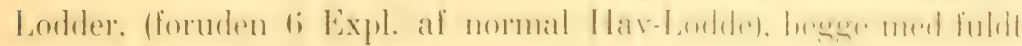
udviklet Rogn.

Under Sonmerfisket i Varanger- og Porsangerfjord findes jevnlig en og anden saadan Fjord-Lodde $i$ Ventrikelen af StorSeien, (som desuden i stor Udstrækning, som ovenfor næunt ${ }^{1}$. nærer sig af Loddens Yngel og Unger).

Om Vinteren træffes disse Stimer ofte helt ind i Bunden af Fjordene, f. Ex. i Mæsketjord inderst i Varangerfjorden, hvor de $\mathrm{i}$ visse Aar endog ere iagttagne at staa under Isen i ikke ubetydeligt Antal2.

()gsa i Trondhjemsfjurden er leilighedsvis of on andet Individ iagttaget om Vinteren.

Elve-Lodde. Paa flere Steder opsoge Lodde-Stimerne om Vaaren Elvemundingerne, hvor de blive staaende en Tid i det halvt ferske Vand, og endog trække et Stykke op i selve Elven.

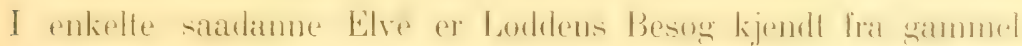

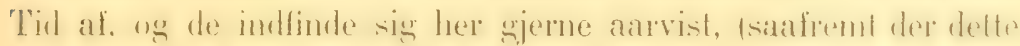

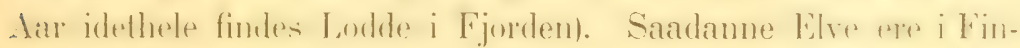

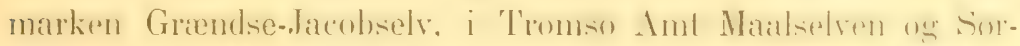

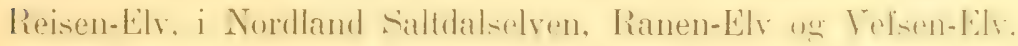

Hvorvidt nogen Gydning finder Sted i selve Elvene, er "ndnu ukjendt. Behoerne have bagttaget, al .modwiderme stat med Snuden mod Elvebunden, som om de sogte Fode". Søn-

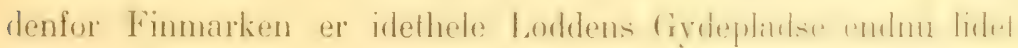
kjendte.

I Sør-Reisen gaar Lodden ${ }^{3}$ lige op i Reisen-Vand, hvis Afstand fra Soen er 4-5 Kilometer; Opstigningen finder Sterl

3 Under et Ophold ved Tamso i Porsangerfjord udtog jeg allerede 2den Juli 1872 af Gabet paa Stor-Sei flere yngre Individer og enkelte storre Exemplarer af denne Fjord-Lodde.

2 G. O. Sars, Indberetn.... Loddefisket ved Finmarken, p. 11 (Chria. 1879).

3 Ifolge Forstmester Hagemann. 
«ndnu, medens Soen er isbedakket. I Naalselven gaar den ligeledes op til (M) Wanken nedenfor Iollæudernæs, eller 4 Kilom. fra suen: den fanges her i Garn, og anvendes til Kreaturfode.

1 Saltalselven i Nordland omtales dens Besog allerede i Beg. af forrige Aarhundrede af Sommerfelt, som nevner (1827). at den gatr op i Elven mellem 9.5de Martsog 14 de April ,for at Eyrle sin Rogn", og at den her fiskes i Miengle for at benyttes til Kreaturfode ${ }^{1}$.

I vor Tid gaar den i denne Elv (ifolge Hagemann) op saalingt fra Elvemundingen, som Son kin merkes red Hoivande. eller et I'ar Kilom. fra Mundingen, og hliver staaende i Elven ontrent 14. Dige, om Vandet er kolit og klart, men kortere, hvis det ar urent. Den upfiskes her med Garn for at benytten som Agn), endum medens Isen ligger. saaledes at demne delvis maa borthugges.

I Teforufjord og Ranenfjorl, hror der ligeledes foregaar et ikke ubetriteligh Intsig om Vararen, hemarkes den i Regelen forst, naar den staar lige udenfor Elvemundingerne.

I Vefsenetvens Munding indtraffe Stimerne i Marts eller April (oftest omkring zbile-27de Marts), og soge ved Hoivande op i Filven. hror de trange op indtil 1 Kilometers Afstand fral Mundingen, hvor Vandet i Bunden endnu or brakt. Deres Antal kan vere saa hetrdelight. at de kumne sive Anledning til et indhringende Fiskeri. Saaledes dreves Fangsten i 1895 af 20 Nothrug. og ier opdiskedes Lodde for 30--10,000 Kroner, der med

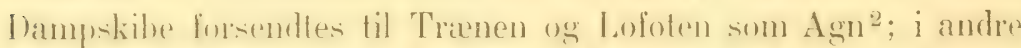
Aar er Udbyttet mindre. Fn Del af Fangsten foregar i selve Elven, og Noten stilles her i Evjer, hvor Strommen er svag; Resten fanges i Elvemundingen, eller i Fjorden udenfor.

Ogsaa her angives Faxe-Lodden at være den forste paa

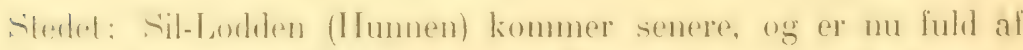

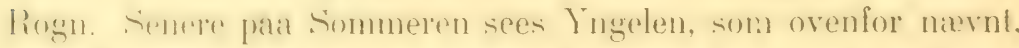
whe i Forden. og kan her iagthages fra selve Brysgerne paa Land.

1 Phys. Oecon. Beskr. af Saltdalen (Kgl. Vid. Selsk. Skr. 19de Aarh. 2 B. 2 H. p. 97 (Thjem. 1824-27).

2 Meddelt af' E. Havno, Rodo. 


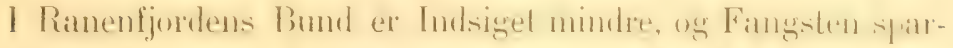

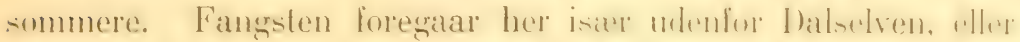

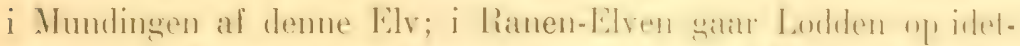

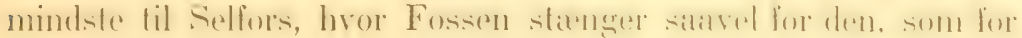
Havvandet.

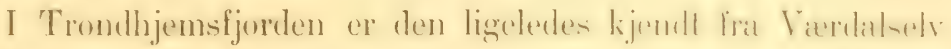

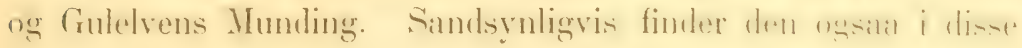
Elvemundinger gunstige Gydepladse med Sandbund.

Sulfossil er M. villosus lundet para lorskjellige sterter i Landet i Glacialtidens Mergeller.

Disse Fund ere gjorte hist og her ligefra Asker (ved Christianiafjorden) ug op til Saltdalen under Polardiketen. Hoilen wer Invels nuvarende Nivean har varet forskjellig, men modertiden gaaet op til over 100 Meter; Afstanden fra Søen har i Regelen været ringe, men har kunnet belobe sig til et Snes Kilometer.

Alle Exemplarer ligge indesluttede i Boller af haard Herael. hrvis sturrelse og ydre Form ofte er i paafaldende Grad svarende. til Skelettets Omrids. Begge Kjon findes representerede, dus

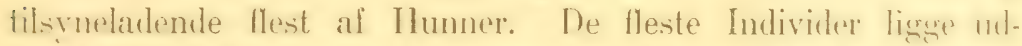
-trakte pail Siden, men enkelte have hrilet pail bugens. med Pectomalerne vifteformigh udbredte til hver side, hvilket agsiat her har givet Bollen dens ydre Contur.

Findestederne for Mergelbollerme have nusten iltid varet de.

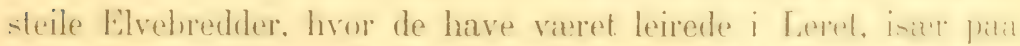

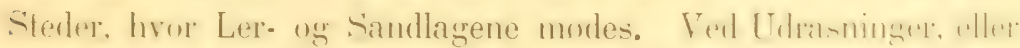
hvor Vandet har udvadsket det fine Grus og Sand, ere de grovere Stene og Bollerne blevne blottede, og kunne findes $\mathrm{i}$

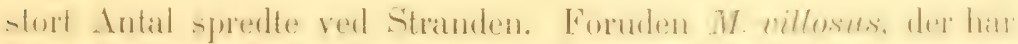

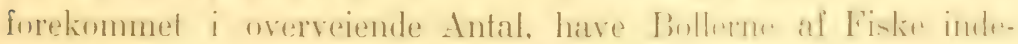

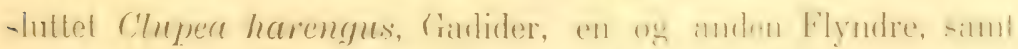

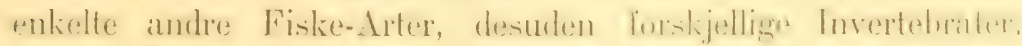
saasom Annelider, Virgularier, og Echinodermer.

De forste af disse Fund ere gjorte af Prof. M. Sars i Gul-

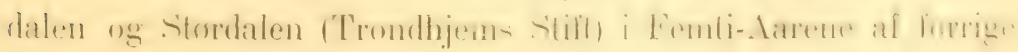

Vid,-Selsk. Forh. 1903. No, 9. 
Aarh., og sentere ere nye Findesteder pariste lige op i vor Tid. De fleste af disse Fund have tidligere (mellem Aarene 1864 $\operatorname{og} 1880$ ) været omtalte og beskrevne ${ }^{1}$

I disse Mergelholler forekommer Lodden hyppigere, end nogen anden Fiske-Art. De specielle Findesteder ere folgende:

a. Hogstad i-Asker. 112 Meter o. Havet². Ved Bredden af en Indso; et enkelt Stykke.

b. Leinstranden, S. Trondhjems Amt. 16 Meter o. Havet. Et enkelt Stykke.

c. Stordalens Prastegand, S. Trondhjems Amt. 16-2001) Meter o. Havet. Et Par Stykker.

d. Melhus, S. Trondhjems Amt. 16 Meter o. Havet. Omtrent et Dusin Stykker, enkelte complette.

e. Kvaal, Guldalen. 47 Meter o. Havet. Et stort Stykke Ler, indeholdende mer eller mindre complette Aftryk af omtr. 11 Expl. (simt 1 St. Pecten islandicus). Desuden foreligger fra et andet Sted i Culdalen (Loraliteten usikker) et halvt Snes Stykier.

f. Aabjorvand, Bindalen, Nordlands Amt. Høiden over Havet omtr. 67 Meter. Et Stykke.

g. Storjord, Beieren, Saltens Fogderi, Nordland (67 N. B:). Ifsiden over llavet ansloges lil omkr. 60 Meler, Afstanden fra

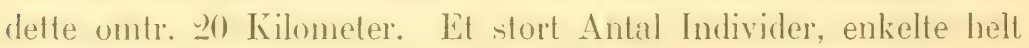
complette.

Disse Mregelloller med Fiskelevninger oplesanes fornemmelig i Chria.- Musect, andre i Museerne i Trundhjem og Tromsos.

1 M. Sars, Fossile Dyrelevninger fra Qvartærperioden (Univ.-Progr. for 1ste Halvaar 1864. Chria. 1865).

MI. Sars, Om Fossiler i glaciale Mergelboller fra Stjordalen (Forh. Vid. Selsk. Chria. 1866. p. 46. Chria. 1867).

Th. Kjevilf, Udsigt over det sydlige Norges Geologi, p. 3. (Chria. 1877).

R. Collett, Norges Fiske (Tillægsh. til Forh. Vid. Selsk. Chria. 1874, p. 164. Chria. 1875). De i Norge hidtil fundne fossile Fiske fra de glaciale og postglaciale Afleiringer (Nyt Mag. f. Naturv. 23de B. 3 H. p. 11. Chria. 1877). Glaciale Mergelboller med indesluttede Fiskelevninger fra Beieren i Salten (Tromso Museums Aarshefter, III, p. 96. Tromsø 1880).

2 Ikke 200 Fod, som paa flere Steder tidligere angivet. 
Argentina sphyraena, Lin. 1766.

Udbredelse. Strom-Silden er udbredt langs Landets sydlige og restlige Kyster idetmindste up til Cimerulsen al Nordlands Amt.

I Christianiafjorden forekommer den lige imb lil onene ndenfor Christiania, og faaes her daglig, isier om Haisten, i dre finmaskede Ciarn, der trakkes elter Smaasidd og Ansju- i lijmentenBund. Fra Fjordens ydre Dele er den kjendt fra de fleste Steder, hor Fiskeri med Garn foregaar; under de al Tr. Iljort dreve binlogicke Undersogelser af Christianiafjorden ug don ()mgivelser i 1\$97-O9 erholdtes den ogsaa i Fjordens Munding (i Langesundsfiford ng Brevigs-fjord) fra en Dybde af !n-110 Meter.

Ved Landet. Sydvestlyst forekommer den utvivkomt langhele Christiansands og Bergens Stifter, og jeg har kunnet underange Exemplarer fra Kragero, Flekkefjord, Christiansand, Slarangertjurdene, og Bergen. Paa flere af disse Steder synes den at være almindelig.

Norrdenfor liergen ar den flere Gange hemarket i Trakten if Aalc:sund, og den er angivet at forekomme par lriskethankerne paa Storeggen, (hvor dog A. silus utvivlsomt er talrigere).

Dens Nordgrandse er endnu usikker. I Trondhjemstijonten ar den ikke sjelden, og flere Individer ere erhvervede for Muset i 'Trondhjem af Conserv. Storm. Det nordligste l'unct, hwortra den hidtil ar kjendt, er Namsenfjord, hvorfra Chrir.-Musent irholdt et Expl., fanget 15de Febr. 1892.

Storrelse. De slorste Individer, jeg hidtil har undersogt,

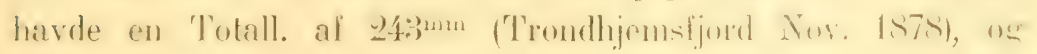
$265^{\mathrm{mm}}$ (Tønsberg April 1881).

Levemaade. Den forekommer pata fur-kijallig Dylude, i liegedent

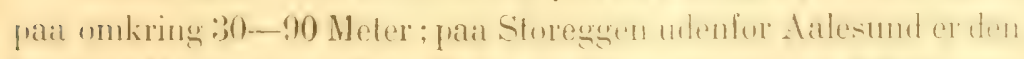

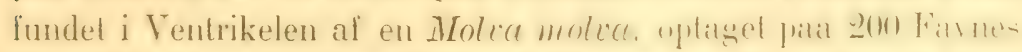

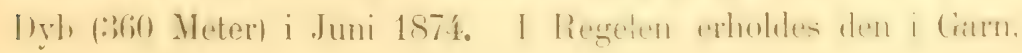


men den bider villigt paa Krog, og mange Individer optages om Vinteren fra Isen paa Lysakerfjord og andre Steder udenfor Christimia handt Smaatorsk og Smanflyndre fra en Dybrle af 10-20 Meter.

Den forekommer stimeris, og Fiskerne have undertiden kunnet faa 100 St. eller mere paa et enkelt Garn. I Beg. af Octoher (1903) uptog saaledes en Fisker i et enkelt Trak onkr. 1 Skjeppe (eller flere Hundrede Individer) mellem Oerne udenfor Christiania. I Regelen erholdes den dog blot enkeltvis eller nogle faa sammen, men er uden Værdi, og bringes sjeldnere tillands.

Naring. Skjont A. sphyraena ifolge sin Bygning maa antages at hente sin Fode hovedsagelig fra de mellenliggende Vandlag, have saagodtsom alle Individer, jeg hidtil har undersogt (fri Christianiafjorden). indeholdt Bunddyr, oftest Annelider (Potynoë, Eunice, Vephthys, Terebella); hos et Expl. tillige en liden Philine. hos el andet ef Par Amphipoder (Apherusa. Halimedon).

Et Expl.. optaget i Brevigsfjord i Oct. 1898, havde Ventrikelen fyldt af Thysanopoder.

For at undersoge denne Arts Niring og Forplantnings-Orsaner har jeg IIosten 1903 aabnet niesten 100 St., alle fangede handt Smatasild og Ansjos (Cl. spraltus) i Lobet af October on November mellem Oerne udenfor Christiania. IIos næsten alle var Ventrikelen fom, eller indeholdt blot Slim, og kun hos (i-S - t. fandtes stierkt fordniede Rester af Forlen, der altid var Amelider. Sandsynligvis tager den sin Fode blot til enkelte 'Tider' af Døgnet, og gaar udenfor disse længe fastende.

Sambidist rare nesten alle Individer forsynede med et Over-kinl af Nieringsstof i Form af en stme eller mindre Fedtsamling. der var fiestet til den ydre Vaxg af Ventrikelen, og strakte sig bagover langs Bughulens Underside med en fri tilspidset Flig. der kunde have en Længde af 1 Tomme eller mere:

Forplandming. Gydetiden synes hus denne Art fog hus A. silns) at indraffe noget uregelmasight, og at strakke sigr 
over fleve Maaneder fra Vaaren lil ifosten, men de flustr syues at gyde om Sommeren.

Flere Exemplarer fra Christianifforden. mulersogte i Marts og April, have endnu havt fast Rogn. Derimod har jeg her

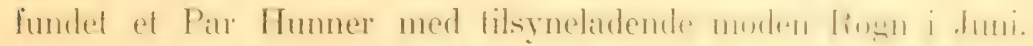

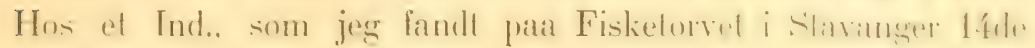
Juni 187?, var Rognen ligeledes nasten moden, wg vilile samlsynligvis være gydt i Juli.

I Octoher ag November (190:3) undersogte jes molmont so udvoxerle Individer, alle fangede i Christianiafjordens inderste loele.

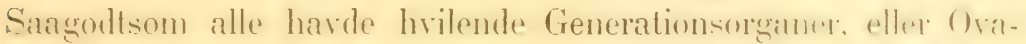
rierne viste de forste Anlarg at Eg: alene en pulcell Ifan haveh

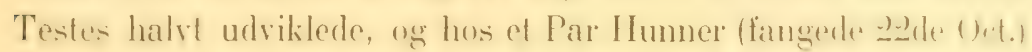
vare tranierne fuldt udvoxede, fyldte hele Pirsthulen lige of

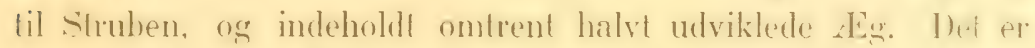
muligt, at dise Fer vilde have reret gydelardige $i$ de hor-h. Vaar-Maaneder.

()gia hos ef Exemplar, optaget i Brevigstjord ste (1). 1s!18, var Rognen blot halvmoden.

De fuldvoxne Rogn have en Diameter af omtr. $1^{\mathrm{mm}}$; deres simlede Antal udgiorde hos ef Ind., fangel ved Christiania I0de. Juni 1877, omtr. 15,000 St.

Yngel eller smaa Unger ere hidtil ikke bemærkede hos os. lee mindste Expl., jeg har undersingt, har havt en Totall. al !sm.

Parasit. Hos flere af de ovenfor næunte (udvoxede) Individer fra Christianifjorden (Hosten 190:3) var Ventrikeden optrilli af en enkelt aflang, valselormig Parasit, der syntes at ulghime ef Starlium af en eller anden anthocephal-lignende finrm. men uden Echinorhynchernes typiske Tornekrands.

Argentina silus, (Ascan.) 1775.

Udbredelse. Denne Art har en videre Udbredelse ved de

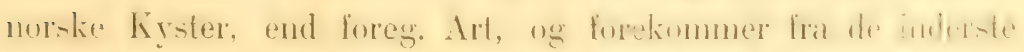

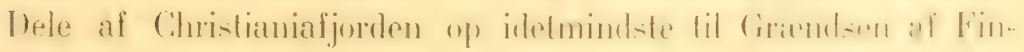
marken, og, som det synes, i ganske stort Antal. 
Den tilhorer fornemmelig det dybere Vand, og findes derfor i strrist Antal i den ydre Skjærgaard og de udenfor liggende T)e af den continentale Platform. I de storre Fjorde forekommer den blot, hvor der findes tilstrixkkelige Dybder, (saasom i Christimialjorden, Sognefjorden, Trondhijemsljorden).

I Christianialjorden el den udbredt paa forskjellige Steder, lwor Dybden er 50) Farne $(90$ Meter) eller derover. I Aug. 1897 optoges den af Dr. Hjort i Drobaksund, og jeg har fra og til fundet Individer paa Fisketorvet i Christiania, fangede i Bundefjorden, saaledes i Fjordens inderste Dele.

I Christianiafjordens ydre Dele er den ligeledes optaget paa de fleste storre Dybder fra Soon og Larkollen af, og til Fjordens Udloh; dog synes den idethele her at viere sparsom. Hyppigere lringes den tillands af Fiskere udenfor Langesund, og Chria.Museet har jevnlig i de senere Aar modtaget Individer herfra; de storste af disse (13de April 1890) havde en Totall. af 4:39 $9^{\mathrm{mm}}$ $\log 452 \mathrm{~mm}$.

Ved Landets Sydkyst forekommer den over hele ArendalsRenden, og den sees ikke sjelden par Torvene om Sommeren i Kragero, Christiansand og Flekkefjord. I dette Bassin er den utvivlsom talrig paa alle storre Dybder; under "Hichael Sars'“ ¿det Togt Sommeren 1901 optoges saaledes paa en enkelt Dag (9de Septemher) i et Par Kast med Otter-Trawlen fra et Dyb af $300-555$ Meter omkring 20 St.

Fra Landets Vestkyst er A. sihes kjenlt fra Stavangerfjordene og langs hele Kysten af Bergens Stift. Den synes her at vare talrig i alle dybere Fjorde: og den har herfira varet kjendt ug heskrevet tilligere, end fra nogen anden Localitet, eller fra den sidste lantvdel af Syttenhundrede-Airrene, fialaledes af Strom 1 ma Gondmor 1750-1791, af Ascamius fra Bergen 1775, af Krog fra Nordfond omkr. 178:3). Om Sommeren bliver den nasten daglig torvfort i liergen, og jeg har flere Gange i Juni til August kumet

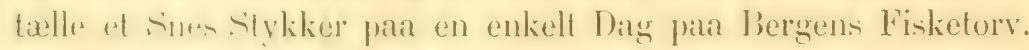

I Tromblyjemsfjorden ar den ligetedes ikke s.jelden. og forekommer her, ifolge storm, lige ind lil heminod Fjordens Bund (udenfor Stenkjær). 
Fra Nordlands Kyst ere endnu kun faa Exemplarer hidtil

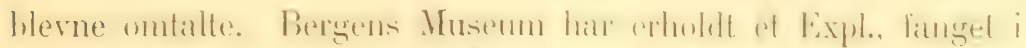

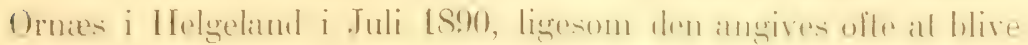
fanget i Fiskeværene udenfor Rodo.

I Lofoten erholdes den jevnlig af Dybvandsfiskerne, men

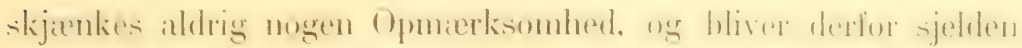

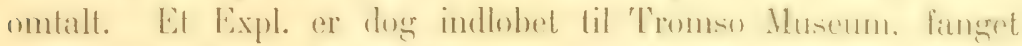

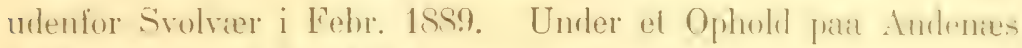

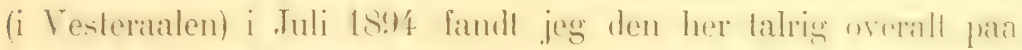
det dybere Vand, hvor den leilighedsvis langedes simmen med de - Arter Lange. Kreite og anden Dyhwandsfisk; et Expl. udloge

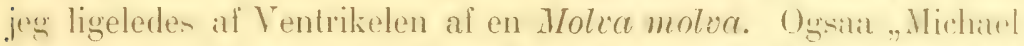
Sars" erholdt under det zdet Togt Sommeren 1901 deme Art

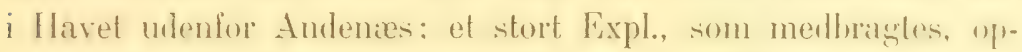
toges fra en Dybde af omkr. 500 Favne (900 Meter).

Endelig er den fremdeles stationær i Fjordene udenfor Tromso, og adskillige Individer ere i Aarenes Iub indlomne til Tromsos Museum fra disse Dele af Kysten. Nordligst er ot Ind. indlobet fra Lyngen under $70^{\circ} \mathrm{N}$. B.. saaledes paa Griendsen af Vest-Finmarken.

candsrnligvis forckommer den paa Dybderne idetmindste (1) til Norkap, men lia det egentlige Finmarken er endnu intet Ind. med Sikkerhed kjendt.

Storrelse. De storiste Individer, jegr hidtil har undersogt fra Norge. have havt en Totall. af 475, mm (Kjerringe i Sillen lSS1).

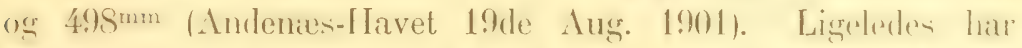

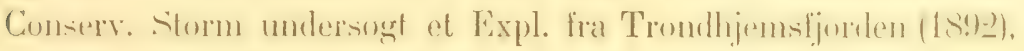
som havde en Totall. af $488^{\mathrm{mm}}$.

Navn. Ved Bergen kalde Fiskerne den Guld-Lax, Vas. Sild, eller undertiden Berg-Lax. I Trondhjemsfjorden og nordover lil Andenæs benævnes den Stav-Sild.

Levemaade. Ligesom A. sphyraena synes den at holde sig

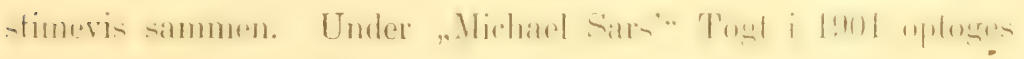


saaledes i at enkelt Kast med Otter-Trawlen (den 9de September) 14. St. Disse vare gjennemgaaende yngre; et Expl., der nu opherares i Chria.-Museet, har en Totall. af $283^{\mathrm{mm}}$. Af Fiskerne rrholdes den oftest paa Krog (med Sild til Agn), og torvfores, -nn ovenfor nevnt, nasten daglig i Bergen, men opmaar ingen betydelig Pris ${ }^{1}$.

Forplantming. Gydetiden indtraffer simdsynligvis i Vareller Sommermaanederne.

Egrgenes Antal er stwrkt varierende efter Individets Sturrelse. Blandt de i Christiania-Mluseet ophevarede Individer findes - rognlyldte Individer, hos hvilke Antallet var folgende:

Totall. $315^{\mathrm{mm}}$, Antal omtr. 3600 St.

Totall. $452^{\mathrm{mm}}$, Antal omtr. 7500 St.

Det storste af disse Exemplarer var fanget i Christianiafjorden (udenfor Larkollen) 31 te Aug. 1855, det mindste i Arendals-Renden (udenfor Langesund) 30te Oct. 1897. Hos begge vare Ėggene endnu umodne, men dog læengst udviklede hos det forstnavnte Individ; sandsynligvis vilde de have væet gydefæerdige $\mathrm{i}$ de første Vaarmaaneder.

Eggene vare alle jevnstore, uden at der forekom blandt dem mindre udviklede Eg. Deres Totall. (hos de lange paa Alcohol opbevarede Exemplarer) var omkr. $2^{\mathrm{mm}}$.

()varierne ere af hetydelig Langde. og fylde hele Bug- og Brysthulen lige op til spiseroret. Ilos det struste Ind. (Totall. $452 \mathrm{~mm}$ ) havde hvert Ovarium en Længde af $160 \mathrm{~mm}$.

Ungerne ere ikke fundne. Det mindste Fxpl.. jeg hidtil har

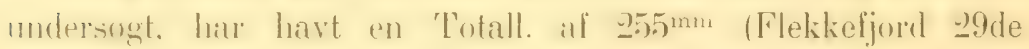
Jan. 1877).

2 I et af den gamle Naturforsker Strom efterladt Manuscript (opbevaret paa Universitets-Bibliotheket i Christiania) anfores, at denne Art fandtes i stort Antal flydende dod i Vandskorpen i Hjorundfjord (Sondmore) i Dec. 1750, hvorefter den i nogle Aar "forsvandt", men viste sig atter i 1766 .

Nogen saadan Dodelighed hos denne Art vides ikke omtalt $\mathrm{i}$ de senere Anr. 


\section{Fam. Esocidae.}

Esox lucius, Lin. 1766.

Udbredelse. Gjedden er i Norge udbredt vasentlig over Z storre Arealer, nemlig i Landets sydlige Dele op til herimon

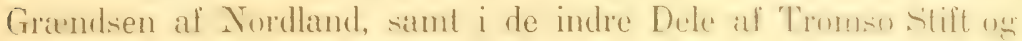
i Finmarken. Para den mellemliggende Strixkning, olla i helt. Nordlands Amt, forekommer den ikke.

1. Det er sandsynligt, at Gjeddens oprindelige Tilhold i

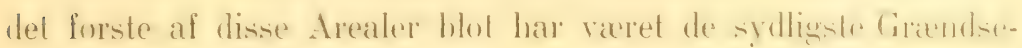
districter mod sierige. og at den her neppe har lorrekommet i rild Tilstand vestenfor Christianiafjorden. Nen elterhatmen er

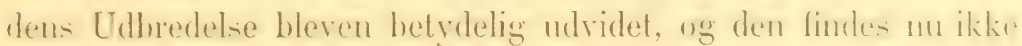
hot $i$ et Ltal af Vande og Vasdrag $i$ hele Christimia still un Dele af Christiansand Stift, men ogsaa, skjont i mindre Udstrækning, langs Landets Vestkyst.

Fra Bergens Stift omtales den imidlertid allerede i det af den gamle Naturlorsker Strom efterladte Manuseriph, (der har dannet Kildeskrifted lil hans ... Sondmors Beskrivelse"). som

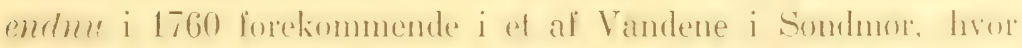
den opreindelig havde vareet indsat af Amtmand Lilliemskindel (sandsynligvis i Slutningen af 1600-Aarene).

Ligeledes forekommer den i flere Vande omkring Bergen,

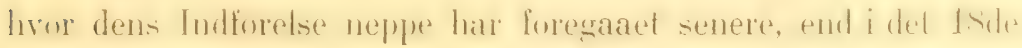
Aarhundrede, men sandsynligvis tidligere.

I Trondhjems Stift findes den ligeledes i mange Vande, satrol sondenfor, som nordenfor Trondhjems forden, nordlig-t i Liernes Præstegjæld nær den svenske Grændse.

2. I hele Nordland synes den, som ovenfor nævnt, endnu at mangle. I det nordlige Distriet optredere den lorrat i simbit-

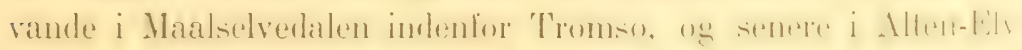
(ovenfor Fossene), og endelig i mange Vande og Elve i Vest-

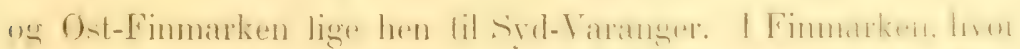

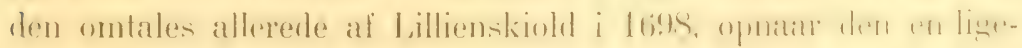
saa betydelig Størrelse, som i Landets sydlige Districter. 
Denne nordlige Stamme har utvivlsomt indvandret ad ostlig Vei giennem Russisk Lapmarken, ligesom forskjellige andre Ferskiandifiske, der befolke disse Arealer, saasom Perca fluviatilis, Phoxinus aphya, Coregonus Tavaretus, Lota lola, og Thymallus thymallus, (saavelsom flere af disse Egnes LandFugle).

Nering. Et Expl., fanget i Johnsvand ovenfor Trondhjem 9de Oct. 1898, og hvis Vregt var 10 Kilogr., havde i Ventrikelen 9 Expl. af Salmo alpinus, alle omtr. $300^{\mathrm{mm}}$ lange.

I Saltvand. I Sept. 1873 fandt jeg et Expl. paa Fisketorvet i Christiania, der var fanget blandt Chupea sprattus i Fjorden udenfor Byen, saaledes i ublandet Saltvand. I Brakvand erholdes den ikke sjelden udenfor Elvemundingerne ved Fredrikshald og Fredriksstad.

\section{Fam. Scombresocidae.}

Scombresox saurus, (Walb.) 1792.

Udbredelse. Makrel-Gjedden er fundet hist og her ved de norske Kyster lige op i Finmarken. Den er oiensynlig bragt under Land med Golfstrommen, men har blot vist sig i spredte Individer, og vides ikke at have ynglet under Kysten.

Enkelt: Aar ere flere Individer iagttagne samtidigt, der maaske have tilhort smaa Stimer, medens de i andre Aar ikke ere med Sikkerhed fundne. Siden Begyndelsen af Otti-Aarene ere idethele niesten et Snes Individer hlevne ophevarede hos os, merlens sandsynligvis samtidigt et langt sturre Antal ikke have været paaagtede.

Disse $i$ de seneste 20 Aar fundne Individer, om hvilke jegr har Kundskab, have været følgende:

Ins:3. 1 Ind.. fundet ved Gjiesvier (nier Nordeap), og indsendt til 'Tromsø Mus; Totall. $245^{\mathrm{mm}}$.

18sx. 5) Expl. re fundne dette Aar paa:) Localiteter fra Christianiafjorden lil Vesteraalen. a. :3 Expl., alle fundne udenfor 


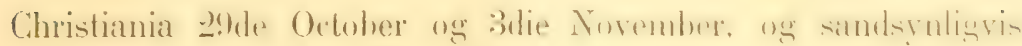
tilhorende en samlet Flok. De 2 forste vare fangede i Garn

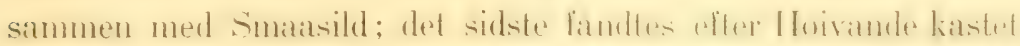
up $\mathrm{i}$ en Groft mer Stranden. (Chria.-Mur.). Lixemplarene have folgende Maal:

Totall. $295^{\mathrm{mm}}$. Hovedets L. $78^{\mathrm{mm}}$.

Totall. $297_{\mathrm{mm}}$. Hovedets L. $80^{\mathrm{mm}}$.

Totall. $300^{\mathrm{mm}}$. Hoverlets L. $79 \mathrm{~mm}$.

b. Et Expl., Skraaven, Lofoten, 26de Sept. 18S4. (Tromso Mus.). c. Fit Expl., Andenies, Testeraalen, Nox. 1884. ('Trumsi) Mus.); 'Totall. $302^{\mathrm{mm}}$.

1887. 1 Expl., Aalesund 15de Marts. (Berg. Mus.); Totall. omtr. $300^{\mathrm{mm}}$.

1891. 1 Expl., Røst, Lofoten, Vaaren 1891. (Chria.-Mus.); 'T'otall. omtr. $325^{\mathrm{mm}}$.

1893. 1 Expl., Gjæsvær, nær Nordcap. (Tromsø Mus.).

189x. 1 Expl., Ramso, Aafjorden (Tromdhjemskisten). Sept. 1894. (Thjems. Mus.); Totall. $440 \mathrm{~mm}$.

1898. 2 Expl. bleve fundne dette Aar udenfor nordre Berzenhus Ant. a. 1 Expl., Bremanger (Sondunor) 9de Aug. (Bers. Mus.); Totall. $303^{\mathrm{mm}}$. b. $1 \mathrm{Expl.,}$ Christiansund Dec. 1898. (Chria.-Mus.); Totall. $352^{\mathrm{mm}}$.

1899. 2 Expl., fundne paa 2 Localiteter i Tromso Amt. a. Bjerkvig i ofoten 24ke Juli. (Tromse Mus.). b. Lit Expl. fanget ved Lyngo nier Tromso, ligeledes i Juli 1899. (Thomsis Mus.); 'Totall. $280^{\mathrm{mm}}$.

1900. 1 Expl., Hilteren Sept. 1900. (Thjems Mus.); 'T'otall. $3.50^{\cdots+11}$.

1901. 2 Expl., Smolen 1901. (Chr.sunds Mus.); udvoxede.

Det vil sees, at de næunte Exemplarer ere fordelte over hele

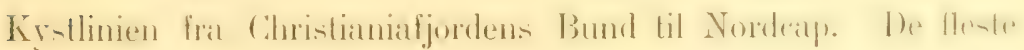
ere erholdte i Hostmaanederne, blot enkelte om Vaaren eller om Sommeren.

Alle have været udvoxede, eller nær derved. Det mindste Ind., som er strandet ved de norske Kyster, har havt en 'l'otall. al

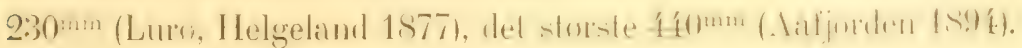


Ramphistoma belone, (Lin.) 1766.

Lidbredelse. Hornfisken er udlredt langs Landets Kystlinie indtil op i Finmarken.

Nordenfor Trondhjemsfjorden optreder den mere sporadisk, og blot enkelte Individer ere kjendte i Landets nordligste Dele. lit Expl. er saaledes indsendt til Tromso Museum fra Sandtory (Hindo), fanget 29) Nor. 1879: i Oxfjord i Vest-Finmarken er den ligeleder en ug anden Gang erholdt, og ('hria.-Nuseet eier et Expl. herfra, fanget i 1866.

Endelig er et enkelt Ind. fanget i Mai 18.7 (blandt Mallotus villosus) i Karlebotn i Varangerfjorden.

Forplantning. Ligesom Aarets Trakfugle indfinde Individerne sig i Christianiafjorden i den forste Halvdel af Mai. De tidligst ankomme pleie at vare de udvoxede Individer, hvis Fogn er gydefardig, samt de noget yngre Individer, hris Totall. er ontr. 500mu. Senere komme ug*aa Ungfiske fra forrige Aar, med en Totall. af omtr. $300^{\mathrm{mm}}$.

Hos et Par gydefærdige Individer (Totall. omtr. 750 $\mathrm{mm}$ ), langede ved Tonsherg t1te Mai (1!:0:3). fandt jeg den samlede liognniengde hos det ene at vare ontr. :31,100 St, hos det andet omtr. 45,600 St. De fuldmodne Rogn, (hvis I) iameter var $\left.: 3,7^{\text {mun }}\right)$, dimnede et sammenhiengende Parti $i$ det indre af de meget lingstrakte Ovarier, meden; der narmest disses Yagge fandtes et storl Autal endum helt umodne Rongn, hororiblandt der kunde være enkelte halvt udvoxede.

Yngel. Nyklekket lingel finden i Christianiafjorden i stort Antal i luni un Juli, og kan optages i Miengde i de fine therfladenet fra Vandskorpen. Den ate Juni 1899 optog Dr. Wollebrekk ${ }^{1}$ udenfor lrobak et nykliekket Individ. Inis Tutall. var onntr. 2mun. Det her holdt levende i el Glas $\mathrm{i}$.) Dage, og naaede

Some Biological Notes (Rep. Norw. Fishery and Marine lnvestig. Vol. I, Chapt. V., p. 118. Chria. 1900). 
i Lobet af denne Tid en Længde af $12 \mathrm{~mm}$. Senere gjenfandtes

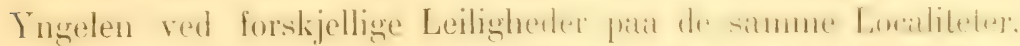

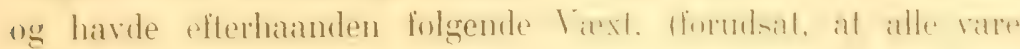
klækkede samtidigt):

5̆te Juli: Totall. omkring $29 \mathrm{~mm}$.

14de Juli: Totall. omkring $41^{\mathrm{mm}}$.

9de August: Totall. omkring $147 \mathrm{~mm}$.

I Slutningen af August var Totall. omkr. 200 mm og derover.

I hele August Milaned kumne store Marsere af Lingor tritflei Fjorden. Paa stille Aftener kunne de sees svømmende om i

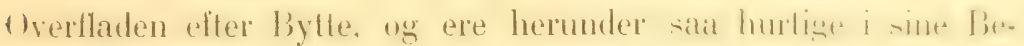
vægelser, at de ere vanskelige at fange.

En Del Yogel, optaget i Overfladenettet patit wrumblt Vamel

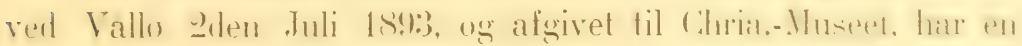
Totall. af $15 \mathrm{~mm}$. Overkjævens Længde er omtr. lig 1, Underkjævens 2 Oiendiametre.

En Del af Yngelen driver dog utvivlsomt med udgaaende

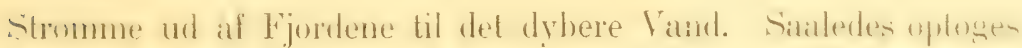
Insel i Itemirhamphus-Stadiet i Arendals-lienden af l)amp-

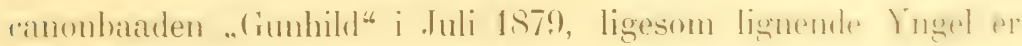
taget af Prof. G. O. Sars ved Espevær i Juli 1873.

Exocoetus volitans, Lin. 1766 (?), Cuv. Val. $184(6$.

Expl. fra 1850. Som tidligere meddelt, er et stort Expl. af en Flyvefisk fanget i Garn ved Moss i Christianiafjorden omtr. 1850, og afgivet til Chria.-Museet, hvor det endnu opbevares.

Bestemmelsen af detle Individ, som er i mindre tilfreds-

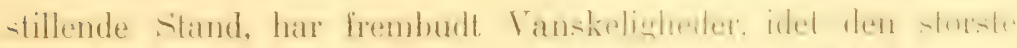

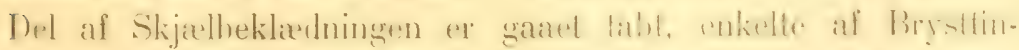

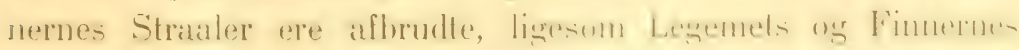
Farve er næsten fuldstændig forsvundet.

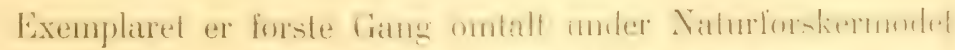

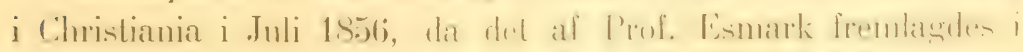


et af Muderne; det henfortes her under Navnet E. volitans, Lin. Cuv. Val. ${ }^{1}$

Under samme Benævnelse er det noiere beskrevet af Forf. i "Norges Fiske" p. 177 (Chria. 1875), skjont det kunde sees i flere Henseender at afvige fra den Beskrivelse af $E$. volitans, som af Dr, Günther er givet i 1866 (i Cat. Fishes Brit. Mus. Tol. VI², sialedes i Antallet af Straaler i Dorsalen og af Skjæl i Sidelinien. og i Ventralernes Stilling i Forhold til Snudespidsen og Haleroden.

I 1876 underkastede Prof. Lütken Exemplaret en fornyet Undersogelse 3, og udtaler som sin Anskuelse, at det idethele staar E. bahiensis, Ranz. nær, men tilhorer maske hverken denne Art, eller E. volitans, Lin., men udgjør snarere en endnu uheskreven Art, der vil blive at stille i Kredsen E. rondeletii, Val.

Endelig har Dr. Boulenger paa min Anmodning netop underkistet Exemplaret en ny Undersigelse; han finder ${ }^{4}$, at Exemplarets refte Benærnelse vil omfatte folgende Synonymer:

E. volitans, Lin. 1766 (?), Cuv. Val. 1846.

E: heterumus, Raf. 1810 (?), Jord. \& Meek 1885.

E. lïtkenii, Jord. \& Everm. 1896.

Exemplarets Totall, er :320 $0^{\mathrm{mm}}$ : Horedets Lengde, ader er (i:mm), indeholdes 5.9 i Totalliengden. Silelinien indeholder omtr. 50 Skjæl. Straaleantallet er: D. 13; A. 9; V. 6; P. 15.

1 Forh. Skand. Naturforskeres 7de Mode Chria. 1856, p. 239. (Chria. 1857).

2 Pag. 293. (London 1866).

3 Vidensk. Medd. fra Naturh. Foren. Kbhyn. 1876, p. 403 (Kbhvn. 1877).

4 Dr. Boulenger anforer i sit Brev (dat. London 5te Juni 1903) følgende: "It is almost impossible to decide what Linnaeus's $E$. volitans really is, and the specimen certainly does not agree with Günthers description in the Cat. of Fishes.

IVe have only one specimen in British Museum that quite agrees with it, and that is one recently received from Rio Janeiro. I dare say it is the E. volitans of C. \& V. It is the E. heterurus of Jordan \& Meek (1885, p. 60), but it is not in agreement with Rafinesque's definition "nAle abdominali situate piu vicino della coda che del capo"

I also think E. Luetieni of Jordan \& Evermann to be the same species." 
1903.] MEDDELELSER OM NORGES FISKE I AARENE 1884-1901. 175

Den 1ste Strate i Pectoralen er kortere, end Finnens halve Liengde (pair den ene Side; den anden Finne er defect). ['ectorralens Farve er forsvundet, men enkelte af shaalerne hase endnu Spor af at have været sorte i sin ydre Del.

(Afsluttes nied Afdeling III). 








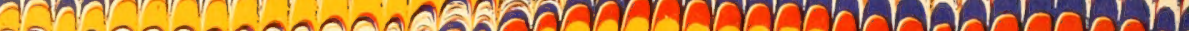




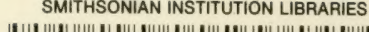

